\title{
Koleksi dan Katalogisasi NASKAH KLASIK KEAGAMAAN BIDANG TASAWUF
}

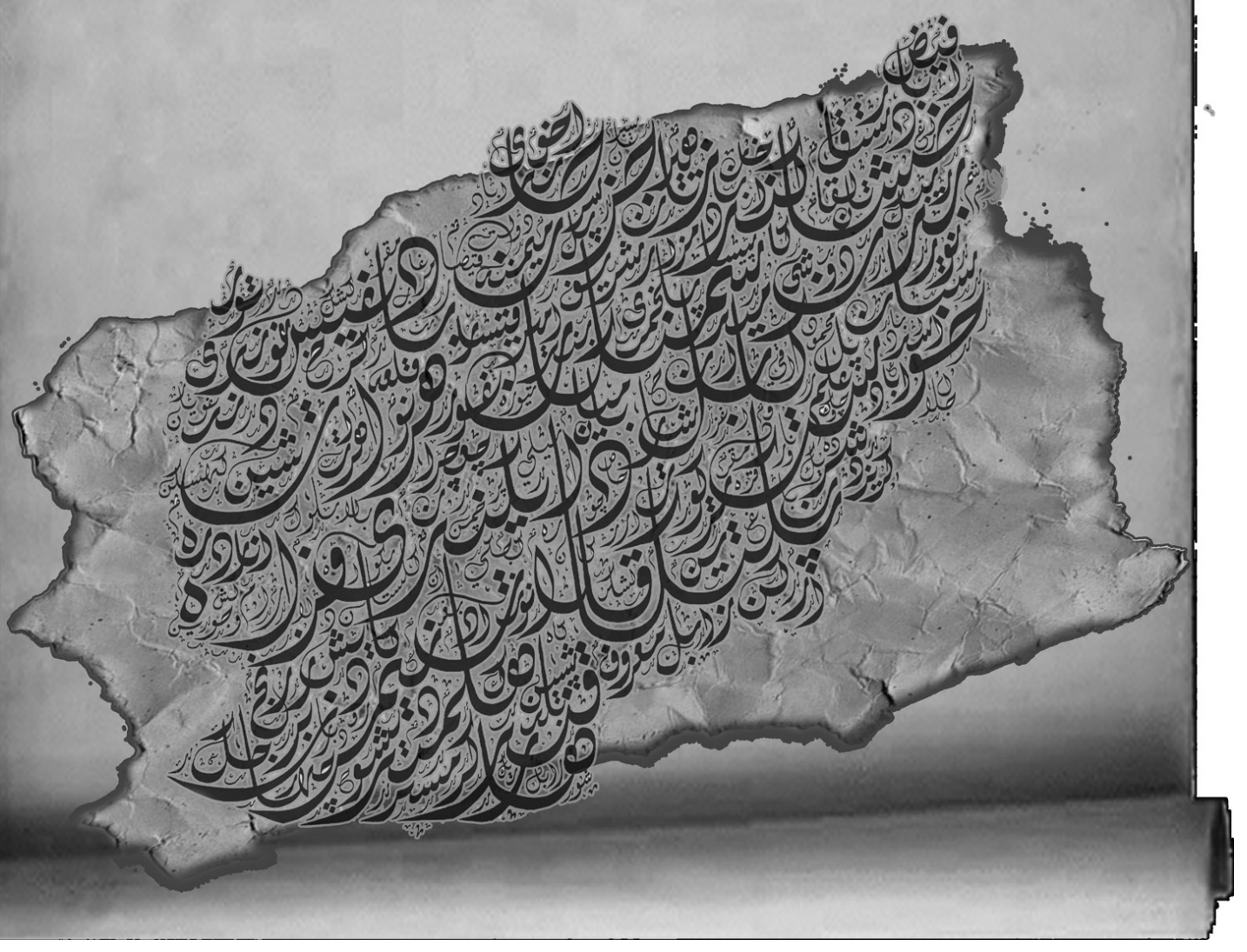



Tim Peneliti

Balai Litbang Agama Jakarta

\section{Kaleksi dan Katalogisasi NASKAH KLASIK KEAGAMAAN BIDANG TASAWUF}

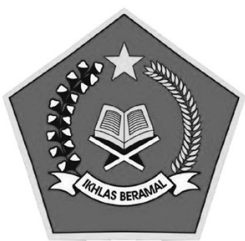

Kementerian Agama

Balai Penelitian dan Pengembangan Agama Jakarta 
Koleksi dan Katalogisasi:

NASKAH KLASIK KEAGAMAAN BIDANG TASAWUF

Copyright@Balai Penelitian dan Pengembangan Agama Jakarta, 2013

\section{Tim Penulis}

Saeful Bahri

Harapandi Dahri

Ahmad Kholid Dawam

Muhamad Rosadi

Syarif

Zulkarnain Yani

Muhammad Tarobin

Cetakan I, Mei 2013

viii +416 hlm: 15 x $23 \mathrm{~cm}$

\section{ISBN: 978-979-9099-84-6}

Penerbit:

Balai Penelitian dan Pengembangan Agama Jakarta

Jln. Rawa Kuning No. 6, Pulo Gebang - Cakung

Jakarta Timur, 13950

Telp.: +62-21-4800725

Faks.: +62-21-4800712

Website: www.blajakarta.kemenag.go.id

\section{Editor: Lukmanul Hakim}

Buku ini dilarang dikutip sebagian atau seluruhnya Tanpa izin dari penerbit HAK CIPTA DILINDUNGI OLEH UNDANG-UNDANG 


\section{KATA PENGANTAR}

Dengan mengucap syukur alhamdulillah, seluruh proses penelitian "Koleksi dan Katalogisasi Naskah Klasik Keagamaan bidang Tasawuf" yang mulai dikerjakan sejak tahun anggaran 2012 ini selesai dilakukan. Penelitian yang mengambil lokasi di Indonesia bagian barat ini dilaporkan dalam buku yang ada di tangan kita. Hasil penelitian ini perlu didokumentasikan karena beberapa alasan berikut.

Naskah tulisan tangan atau dikenal dengan nama manuskrip, pernah dilukiskan oleh Taufik Abdullah (2001: 14) sebagai buah dari 'kegelisahan intelektual' para cerdik cendikia masa lalu. Sebagian besar dari para penulis teks-teks nusantara itu juga adalah dari kalangan ahli-ahli agama, guru sufi, kyai, dan para mubaligh, selain para sastrawan tentunya, yang memiliki kepedulian untuk menerjemahkan Islam dalam konteks dan bingkai budaya lokal.

Pun terjemah yang dimaksud di sini bukan semata alih bahasa satu teks menjadi teks baru dalam bahasa lain, melainkan lebih dari itu penerjemahan ide, gagasan, dan bahkan ideologi dari sumbernya yang dianggap 'asing' menjadi sumber yang diyakini sebagai 'milik sendiri' (lihat Chambert-Loir [peny.] 2009). Karenanya, khazanah manuskrip nusantara yang kini kita miliki, dan terhubungkan dengan Islam, sedemikian dinamis dan merepresentasikan beragam 'tafsiran' ---dari mereka yang oleh Taufik Abdullah disebut sebagai brokers of ideas (1987: 239)--terhadap ideologi-ideologi yang lahir dari konteks pemikiran dan budaya lain, seperti Arab, Persia, India, dan lain-lain.

'Model rahim' seperti itulah, lahir dengan apa yang dapat kita sebut sebagai manuskrip Islam nusantara, dalam jumlah yang sangat besar. Kita bisa menyebut sejumlah kelompok bahasa lokal 
dari berbagai etnis, yang digunakan untuk menulis manuskripmanuskrip tersebut, seperti Aceh, Bugis-Makassar, Mandar, Jawa, Madura, Melayu, Minangkabau, Sasak, Sunda, Wolio, dan beberapa bahasa lainnya, di samping tentu saja bahasa Arab yang menjadi 'induknya' (gambaran tentang keragaman khazanah naskah nusantara secara umum, lihat Chambert-Loir \& Fathurahman 1999).

Ketentuan Undang-Undang No. 11 Tahun 2010 menyatakan, bahwa manuskrip dapat dimasukkan dalam kategorisasi benda cagar budaya, karena yang dimaksud dengan benda cagar budaya adalah benda alam dan/atau benda buatan manusia, baik bergerak maupun tidak bergerak, berupa kesatuan atau kelompok, atau bagian-bagiannya, atau sisa-sisanya yang memiliki hubungan erat dengan kebudayaan dan sejarah perkembangan manusia.

Sebagai salah satu kekayaan budaya, manuskrip harus dikelola dengan tepat melalui upaya perlindungan, pengembangan, dan pemanfaatannya. Kenyataan menunjukkan, bahwa cagar budaya yang kita miliki masih banyak permasalahan, baik dalam penamaan, penghitungan, maupun dalam klasifikasinya. Pada konteks ini, Balai Litbang Agama Jakarta ingin berkontribusi dalam upaya inventarisasi, klasifikasi, dan katalogisasi melalui sebuah penelitian, dan hasilnya terdokumentasikan dalam buku ini. Karenanya, dengan terbitnya buku ini sangat besar harapan, bahwa di masa mendatang berbagai hasil inventarisasi yang terbukti berhasil menunjukkan peradaban tinggi Islam nusantara, dapat memicu dilakukannya berbagai kajian Islam nusantara melalui manuskrip dan kitab yang pernah ditulis oleh para pengarang masa lalu, sehingga para sarjana pribumi dapat mengembangkan sendiri kesarjanaan berstandar internasional di bidang kajian manuskrip Islam nusantara tersebut. Semoga!

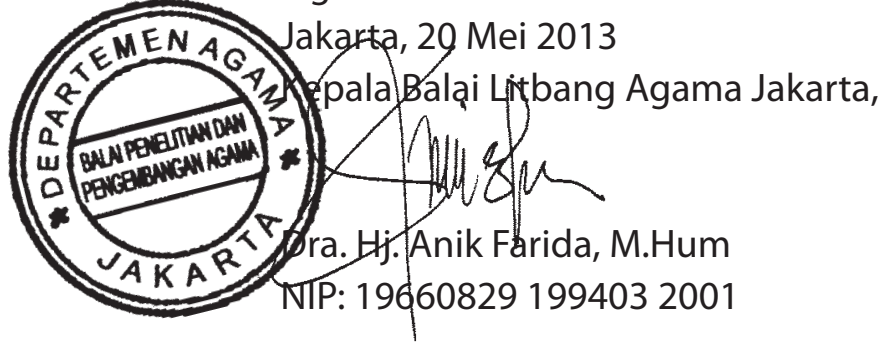




\section{DAFTAR ISI}

KATA PENGANTAR

BABI : PENDAHULUAN

Latar Belakang

$\rightarrow$ Tujuan dan Target Penelitian --------------- 7

Kerangka Konsep dan Teori ----------- 7

Wilayah, Tim, dan Jumlah Naskah -------- 11

BAB II : NASKAHTASAWUF DI PROPINSI ACEH

(KOLEKSI MUSEUM NEGERI ACEH)

Oleh: Saeful Bahri

BAB III : NASKAHTASAWUF

DI PROPINSI SUMATERA BARAT (PADANG)

Oleh: Zulkarnain Yani

BAB IV : NASKAHTASAWUF

DI PROPINSI SUMATERA UTARA (MEDAN)

Oleh: Ahmad Kholid Dawam dan Syarif

BAB V : NASKAHTASAWUF

DI PROPINSI SUMATERA SELATAN

271

Oleh: Muhammad Tarobin 
Daftar Isi

BAB VI : NASKAH TASAWUF DI PROPINSI BANTEN 315 Oleh: Muhamad Rosadi

BAB VII : NASKAHTASAWUF

DI PROPINSI JAWA BARAT (CIREBON)

Oleh: Harapandi Dahri

DAFTAR PUSTAKA 407

DAFTAR INDEKS 409

[viii] 


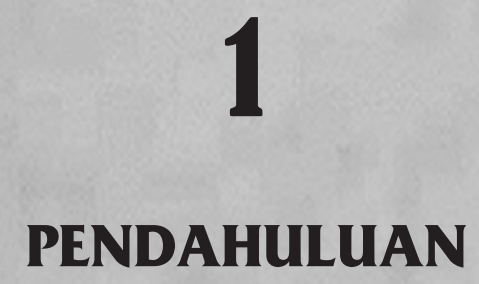

(5)

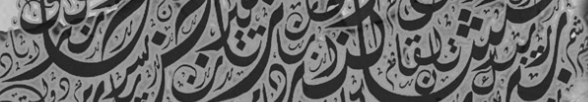

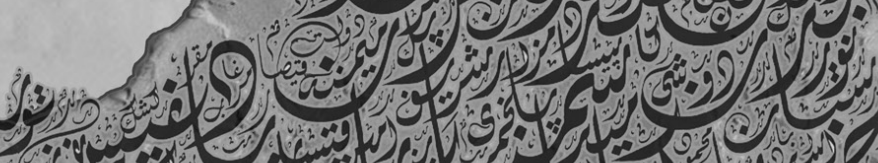

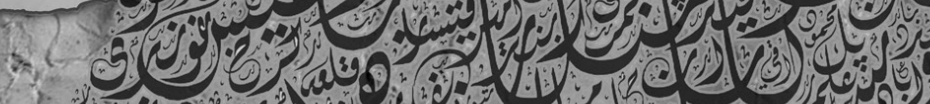

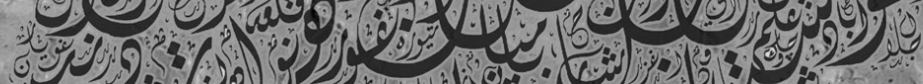

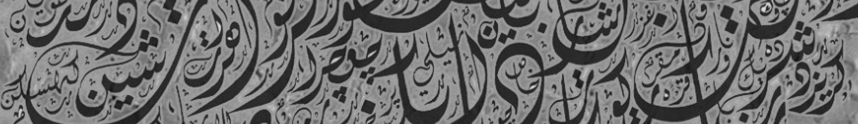

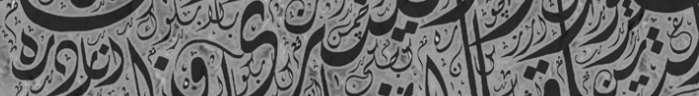

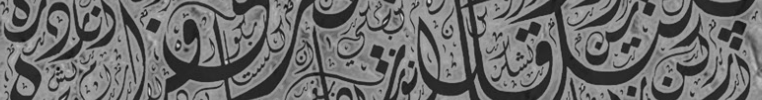

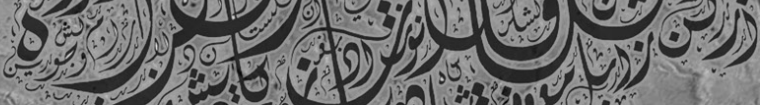

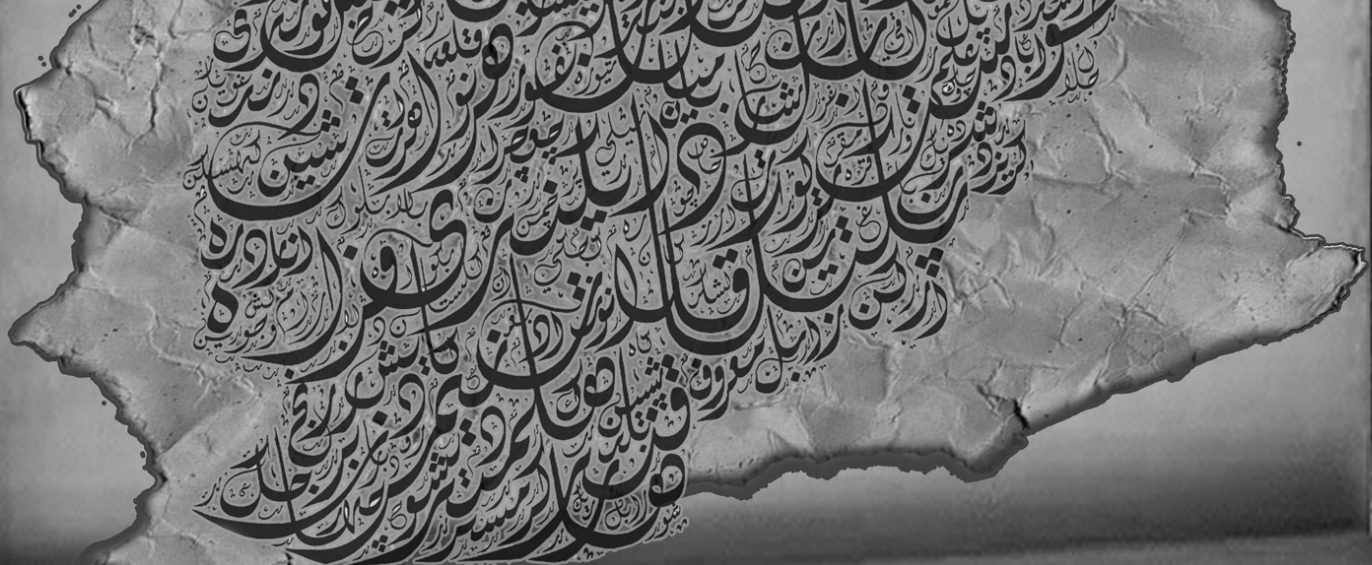




\section{Latar Belakang}

Naskah tulisan tangan (manuscript) merupakan teks tertulis yang mengandung berbagai pemikiran, pengetahuan, adat istiadat, dan perilaku masyarakat masa lalu. Dibandingkan dengan bentukbentuk peninggalan budaya material non-tulisan di Indonesia, seperti candi, istana, masjid, dan lain-lain, jumlah peninggalan budaya dalam bentuk naskah jauh lebih besar (Achadiati, 1997:24). Sebagai warisan budaya bangsa, upaya pelestarian, konservasi, dan penggalian materi dan nilai-nilai yang terkandung di dalamnya merupakan sesuatu yang sangat diperlukan (Fadhal Bafadhal (ed.), 2006: xiii).

Di antara berbagai kategori naskah nusantara, naskah keagamaan (baca:Islam) merupakan salah satu jenis kategori naskah yang jumlahnya relatif banyak. Hal ini tidak terlalu mengherankan, mengingat kenyataan bahwa ketika Islam - dengan segala kekayaan budayanya- masuk di wilayah nusantara pada umumnya, dan di wilayah Melayu - Indonesia pada khususnya, budaya tulis-menulis sudah relatif mapan (Oman Fathurahman, 2008:18).

Naskah Islam Indonesia merupakan salah satu warisan Islam yang tidak ternilai di nusantara. Naskah-naskah yang tersedia dalam berbagai bahasa dan aksara lokal ${ }^{1}$ di Indonesia dalam banyak segi mengungkapkan berbagai aspek Islam di kawasan ini, mulai dari yang bersifat sejarah sosial dan terutama lagi pemikiran dan intelektualisme Islam, khususnya sejak masa awal Islam dan masa kolonial Belanda, tanpa penelitian dan pengkajian terhadap naskah (Azyumardi Azra, 2010).

'Dalam konteks naskah keagamaan, ada dua kelompok bahasa naskah; pertama, naskah-naskah yang ditulis dalam bahasa Arab; dan kedua, naskah-naskah yang ditulis dalam bahasa-bahasa daerah. Lihat Oman Fathurahman, Tarekat Syattariyah di Minangkabau: Teks dan Konteks, 18. 
Keberadaan naskah klasik keagamaan Islam tersebar di seluruh wilayah nusantara, bahkan ada di negara-negara lain, seperti Belanda, Malaysia, Filipina, dan negara lainnya. Naskahnaskah tersebut berbicara mengenai persoalan tauhid, tasawuf, tarekat, fiqih, hadis, dan tema-tema lainnya, yang masih menjadi pedoman dan acuan kehidupan keagamaan di Indonesia sampai saat ini. Banyaknya naskah yang tersebar di masyarakat menarik minat para peneliti, pemerhati naskah, bahkan kolektor naskah untuk terus melakukan inventarisasi dan pendataan naskah-naskah tersebut.

Mengenai pentingnya naskah (manuskrip) sebagai sebuah benda cagar budaya yang harus dilindungi dan bermanfaat bagi evaluasi dan pengembangan kebudayaan sudah barang tentu sudah tidak perlu lagi diberikan penjelasan secara rinci. ${ }^{2}$ Hanya saja yang perlu digaris bawahi adalah upaya penelitian dan katalogisasi naskah-naskah tasawuf ini adalah sebuah action (aksi) dari sebuah kebijakan (policy). Setidaknya ada tiga kebijakan yang dapat dirujuk dari kegiatan katalogisasi ini, yaitu:(1) UU No. 11 Tahun 2010 tentang Cagar Budaya; (2) UU No. 43 Tahun 2007 tentang Perpustakaan; dan (3) Rencana Strategis Kementerian Agama Tahun 2010-2014.

Di dalam Pasal 1 ayat (1) UU No. 11 Tahun 2010 menyatakan, bahwa cagar budaya adalah:

"Warisan budaya bersifat kebendaan berupa Benda Cagar Budaya, Bangunan Cagar Budaya, Struktur Cagar Budaya, Situs Cagar

\footnotetext{
${ }^{2}$ Setidaknya ada dua undang-undang yang dapat dijadikan dasar dalam hal ini, yakni UU No. 11 Tahun 2010 tentang Cagar Budaya dan UU No. 43 Tahun 2007 tentang Perpustakaan, khususnya pada bagian naskah kuno. Mengenai peran studi pernaskahan nusantara dan studi filologi secara khusus sebagai alat evaluasi dan sumber inspirasi pengembangan kebudayaan telah diungkapkan oleh Siti Baroroh Baried dkk, Pengantar Teori Filologi. (Yogyakarta: Badan Penelitian dan Publikasi Fakultas, UGM Yogyakarta, 1994), 91-96. Mengenai ulasan pentingnya studi filologi di era pembangunan, bisa juga dibaca dalam Alex Sudewa, "Filologi dalam Era Pembangunan," Majalah Basis, Oktober 1984, 372-375. Sudewa menjelaskan, bahwa seorang filolog bisa secara langsung memberi umpan kepada ahli ilmu sosial dalam mencari hakikat budaya Indonesia. Banyak karya babad yang mengandung peristiwa historis dengan latar belakang sosial, politik, dan religius-nya yang belum pernah diterbitkan dengan pertanggungjawaban filologis, apalagi dikaji isinya. Menurut Sudewa, seorang filolog layaknya pemberi/pemain umpan dalam permainan sepak bola yang memberikan umpan kepada teman mainnya. Kerja para filolog dalam era pembangunan adalah umpan terobosan yang dikirimkan kepada pencetak gol, yakni para peneliti ilmu sosial.
} 
Budaya, dan Kawasan Cagar Budaya di darat dan/atau di air yang perlu dilestarikan keberadaannya karena memiliki nilai penting bagi sejarah, ilmu pengetahuan, pendidikan, agama, dan/atau kebudayaan melalui proses penetapan".

Kemudian Pasal 26 ayat (1) menyatakan, bahwa "pemerintah berkewajiban melakukan pencarian benda, bangunan, struktur, dan/atau lokasi yang diduga sebagai cagar budaya. Lalu pada ayat (3) mengatur, bahwa "pencarian hanya dapat dilakukan melalui penelitian dengan tetap memperhatikan hak kepemilikan dan/ atau penguasaan lokasi".

Di dalam undang-undang cagar budaya di atas, sebetulnya naskah kuno (manuskrip) dapat masuk ke dalam kategori benda cagar budaya, yang merupakan buatan manusia dan mempunyai nilai penting bagi sejarah, ilmu pengetahuan, pendidikan, agama, dan kebudayaan. Hal ini lebih ditekankan lagi dalam Penjelasan UU No. 43 Tahun 2007 tentang Perpustakaan, terutama pada Pasal 7 ayat (1) huruf i yang menyebutkan, bahwa "naskah kuno berisi warisan budaya karya intelektual bangsa Indonesia yang sangat berharga dan hingga saat ini masih tersebar di masyarakat dan untuk melestarikan perlu peran pemerintah". Sedangkan yang dimaksud dengan "naskah kuno" itu sendiri, Pasal 1 ayat (4) memberikan arti sebagai "semua dokumen tertulis yang tidak dicetak atau tidak diperbanyak dengan cara lain, baik yang berada di dalam negeri maupun di luar negeri yang berumur sekurang-kurangnya 50 (lima puluh) tahun, ${ }^{3}$ dan yang mempunyai nilai penting bagi kebudayaan nasional, sejarah, dan ilmu pengetahuan".

${ }^{3}$ Para filolog berbeda pendapat mengenai batasan waktu kekunoan naskah ini, jika UU No. 43 Tahun 2007 membatasi waktu naskah minimal 50 tahun, maka sebagian filolog, seperti Uka Tjandrasasmita berpendapat, bahwa yang dimaksud naskah dalam kajian filologis adalah dokumen tulisan tangan yang muncul (dikarang dan disalin) mulai pada paruh pertama abad ke-16 sampai paruh pertama abad ke-19. Sebagian filolog lain lebih longgar dalam membatasi waktu minimal ketuaan sebuah naskah, seperti Oman Fathurahman berpendapat, bahwa tidak perlu dibatasi oleh waktu semacam itu, karena yang terpenting adalah adanya sebuah teks dalam sebuah naskah yang menurut pertimbangan dan penelitian sangat bernilai baik dari sisi budaya, sejarah, dan ilmu pengetahuan, tetapi tentu saja semakin tua sebuah naskah semakin penting untuk diberikan tindakan (baik pencarian, penyelamatan, pemeliharaan, dan pengkajian). Oleh karena itu, yang dikedepankan adalah pertimbangan prioritas. Lihat Oman Fathurahman, Filologi dan Islam Indonesia, (Jakarta: Puslitbang Lektur Keagamaan, Badan Litbang dan Diklat Kementerian Agama, 2010), 6. 
Terkait dengan nilai penting naskah keagamaan bagi kehidupan keagamaan dan budaya, hal itu juga mendukung salah satu prioritas pembangunan dan peningkatan kualitas pemahaman dan pengamalan kehidupan beragama oleh Kementerian Agama, yakni melalui penguatan peran agama dalam pembentukan karakter dan peradaban bangsa, sebagaimana yang tertuang dalam Rencana Strategis Kementerian Agama Tahun 2010-2014. Selain itu, penelitian naskah-naskah keagamaan adalah juga bagian dari penyediaan media informasi keagamaan yang berbasiskan budaya Indonesia.

Adapun alasan naskah-naskah tasawuf yang dijadikan obyek katalogisasi ini, karena dari beberapa studi literatur dan katalog yang ada, naskah-naskah yang berisikan teks-teks tasawuf di nusantara cukup banyak, dan menempati urutan kedua setelah naskah-naskah fiqih. ${ }^{4}$ Selain itu, yang penting dikemukakan juga, bahwa guru-guru sufi pengembara (orang yang menjalankan perilaku tasawuf), sebagaimana pendapat Johns (A. Johns, 1987: 86) dan dikuatkan dengan Azra (Azyumardi Azra, 2007:14-15), adalah yang paling berperan dalam penyebaran Islam di nusantara. Belakangan, para guru sufi ini banyak menghasilkan karya-karya tulis di bidang ilmu agama, khususnya tasawuf, meskipun sering pula dihubungkan dengan fiqih dan tauhid. ${ }^{5}$ Dengan demikian, koleksi dan katalogisasi naskah-naskah keagamaan, dalam hal ini bidang tasawuf, menjadi penting didasarkan beberapa argumen yang diurai di atas.

${ }^{4}$ Lihat misalnya, Oman Fathurahman, Katalog Naskah Dayah Tanoh Abee Aceh Besar, xviii. Dalam katalog ini, naskah-naskah teks tasawuf kebetulan menempati urutan ketiga setelah fiqih dan tata bahasa, serta sejajar dengan tauhid. Meskipun naskah-naskah teks tasawuf berada setelah tata bahasa, tasawuf tetap menempati teks yang banyak dikaji. Hal ini sama dengan naskah-naskah koleksi Ali Hasymi, yang sama-sama berada setelah naskah-naskah teks tata bahasa, tetapi lebih banyak dari pada naskah-naskah teks tauhid. Lihat Oman Fathurahman dan Munawar Holil, Katalog Naskah Ali Hasymy Aceh, viii.

${ }^{5}$ Untuk ulasan lebih dalam dan baik mengenai tokoh-tokoh sufi, baca Azyumardi Azra, Jaringan Ulama Timur Tengah dan Kepulauan Nusantara. Khususnya pada bab IV dan V. 


\section{Tujuan dan Target Penelitian}

Adapun tujuan dan target yang hendak dicapai dalam penelitian ini antara lain:

1. Melaksanakan amanat UU No. 11 Tahun 2010 tentang Cagar Budaya dan UU No. 43 Tahun 2007 tentang Perpustakaan, yang menekankan peran pemerintah dalam pencarian dan pelestarian naskah kuno sebagai bagian dari benda cagar budaya.

2. Penguatan peran agama dalam pembentukan karakter dan peradaban bangsa dan penyediaan media informasi keagamaan yang berbasiskan budaya Indonesia sebagaimana dituangkan dalam Renstra Kementerian Agama 2010-2014.

3. Menyediakan infrastruktur penelitian naskah keagamaan, berupa penyediaan basis data naskah-naskah Islam, yang bermanfaat bagi para peneliti atau masyarakat yang fokus dengan bidang pernaskahan.

\section{Kerangka Konsep dan Teori}

Kata 'koleksi' secara bahasa berarti: (1) kumpulan (gambar, benda bersejarah, lukisan, dan sebagainya) yang sering dikaitkan dengan minat atau hobi objek (yang lengkap); (2) kumpulan yang berhubungan dengan studi penelitian; (3) cara mengumpulkan gambar, benda bersejarah, lukisan, dan objek penelitian (KBBI, 580).

Dalam konteks katalog ini, arti yang digunakan adalah arti yang pertama, sehingga yang dimaksud dengan koleksi dalam katalog ini adalah kumpulan naskah kuno/klasik yang terkait dengan tema-tema tasawuf. Adapun katalogisasi adalah kata benda yang menunjuk pada perkatalogan; pendaftaran buku (KBBI: 515). Dalam konteks ini, katalogisasi adalah pendaftaran atau deskripsi yang memuat informasi mengenai naskah-naskah tasawuf.

Naskah adalah dokumen tulisan tangan, bukan merupakan isi dari naskah tersebut, tapi wujud fisiknya (dokumennya). Sedangkan isi kandungan dari naskah biasanya disebut dengan 
"teks". Suatu naskah bisa saja terdiri dari beberapa teks, tetapi suatu teks bisa terdapat pada lebih dari satu naskah. Dalam bahasa Inggris naskah disebut dengan manuscript/manuscripts, disingkat MS/MSS, dan dalam bahasa Belanda naskah disebut dengan handschrift/ handschriften, disingkat HS/HSS. "Naskah kuno" berarti adalah naskah-naskah dari masa lampau, dan ada juga yang menyebut naskah klasik untuk menyaran pada naskah-naskah yang memiliki keunggulan atau contoh terbaik.

Istilah naskah kuno atau naskah klasik membutuhkan penjelasan kategori atau batasan waktu. Waktu manakah yang masuk dalam kategori kuno atau klasik itu? Batasan klasik untuk naskah klasik Islam yang dibuat oleh Uka (Uka Tjandrasasmita, 2009:215) dengan menganalogikan dengan pendapat Braginsky (Barginsky, 1993:8-10), yakni dari awal abad ke-16 sampai pertengahan abad ke-19. Pendefenisian yang lebih longgar dan moderat adalah definisi naskah kuno yang tercantum pada UU No. 43 Tahun 2007 tentang Perpustakaan, bahwa naskah kuno atau klasik adalah semua dokumen tertulis yang tidak dicetak atau tidak diperbanyak dengan cara lain, yang berumur sekurang-kurangnya 50 (lima puluh) tahun, dan yang mempunyai nilai penting bagi kebudayaan nasional, sejarah, dan ilmu pengetahuan. Konsep naskah kuno atau klasik yang terakhir inilah yang akan digunakan.

Di dalam penelitian filologi, katalog naskah merupakan kebutuhan yang mendasar karena di dalamnya menyimpan berbagai informasi mengenai naskah-naskah yang akan diteliti dan dikaji. Dalam menyusun sebuah katalog naskah, maka diperlukan sebuah ilmu yang membantu para peneliti dan pemerhati naskah dalam menyusun katalog naskah yang benar yaitu kodikologi.

Kodikologi adalah upaya untuk mengungkap seluk-beluk atau semua aspek naskah tentang bahan, umur, tempat penulisan dan perkiraan penulis naskah, dan lain sebagainya. Secara induktif, kodikologi mengenai naskah-naskah dapat memberikan gambaran mengenai tradisi tulis menulis yang pernah ada di masa lampau, skriptorium-skriptorium yang dulu berkembang serta struktur- 
struktur yang mendorong atau menghancurkan suatu budaya tulis (S.W.R. Mulyadi, 1994:1).

Kodikologi sebuah kata yang berasal dari kata Latin codex yang di dalam bahasa Indonesia diterjemahkan menjadi naskah, bukan menjadi kodeks. Robson menyebutkan, bahwa kodikologi sebagai pelajaran naskah, sedangkan Barried (Siti Baroroh Barried dkk, 1994:56) mengatakan, bahwa kodikologi adalah ilmu kodeks. Kodeks adalah bahan tulisan tangan. Kodikologi mempelajari seluk beluk semua aspek naskah, antara lain; bahan, umur, tempat penulisan, dan perkiraan penulis naskah.

Hermans dan Huisman menjelaskan, bahwa istilah kodikologi diusulkan oleh seorang ahli bahasa Yunani Alphonse Dain. Istilah ini baru terkenal pada tahun 1949 ketika karyanya Les Manuscrits diterbitkan untuk pertama kali pada tahun tersebut. Seperti yang Dain (A. Dain, 1975: 76-77) katakan, kodikologi adalah ilmu mengenai naskah-naskah dan bukan ilmu yang mempelajari apa yang tertulis di dalam naskah. Menurut Dain, bahwa tugas dan daerah kodikologi antara lain sejarah naskah, sejarah koleksi naskah, penelitian mengenai tempat naskah-naskah yang sebenarnya, masalah penyusunan katalog, penyusunan daftar katalog, perdagangan naskah, dan penggunaan naskah-naskah tersebut.

Kodikologi atau biasa disebut ilmu pernaskahan bertujuan mengetahui segala aspek naskah yang diteliti. Aspek-aspek tersebut adalah aspek di luar isi kandungan naskah tentunya. Analisis kodikologi ini, sesuai dengan tujuannya tadi, yaitu penyusunan daftar katalog, selanjutnya juga memberi perhatian pada fisik naskah. Kenapa? Karena dalam katalog, biasanya terdapat juga deskripsi fisik naskah selain informasi tentang di mana naskah itu berada.

Pendeskripsian ini berguna untuk membantu para peneliti mengetahui ketersediaan naskah itu, sehingga memudahkan penelitian. Maka selain mencari asal-usul dan kejelasan mengenai kapan, bagaimana, dan dari mana naskah tersebut dihasilkan, 
analisis kodikologi juga berkembang juga pada ada atau tidaknya judul naskah, biasanya penulis atau penyalin memberikan judul naskah di awal teks, pertengahan atau di akhir teks, kalau tidak ada judul naskah maka kita wajib memberikan judul sendiri sesuai dengan isi kandungan naskah tersebut.

Tempat penyimpanan naskah, informasi ini dapat berupa nama lembaga (yayasan, museum, perpustakaan, masjid, kantor) dan perorangan. Ada tidaknya penomoran naskah, kalau dijumpai nomor naskah yang lebih dari satu, hendaknya kedua-duanya didaftarkan dengan menuliskan nomor yang baru dan disusul oleh nomor yang lama di antara kurung. Selain itu, juga mengenai ada atau tidaknya iluminasi dan ilustrasi, ${ }^{6}$ jumlah kuras naskah, bentuk jilidannya, sejauhmana kerusakan naskah (robek, terbakar, terpotong, rusak karena pernah terkena cairan, dimakan binatang, berjamur, hancur atau patah, dan lain-lain), pendek kata segala hal yang bisa diketahui mengenai naskah itu.

Hal awal yang biasanya dilakukan dalam analisis kodikologi adalah menelusuri sejarah naskah. Sejarah naskah biasanya didapat dari catatan-catatan di halaman awal atau akhir yang ditulis oleh pemilik atau penyimpan naskah itu. Fisik naskahnya, yang dilihat adalah panjang, lebar, ketebalan naskah keseluruhan, panjang, lebar, dan jumlah halaman yang digunakan untuk menulis, dan bahan atau media naskah.

Setelah hal-hal di atas, kita masuk ke bagian dalam naskah, yaitu bagian naskah yang ditulisi atau teks. Di sini kita akan melihat jenis huruf atau aksara dan bahasa yang digunakan, ada atau tidaknya rubrikasi atau penanda awal dan akhir bagian dalam tulisan (biasanya berupa tulisan yang diwarnai berbeda dengan tulisan isi), ada atau tidaknya catchword atau kata pengait, yang biasanya digunakan untuk menandai halaman naskah dan bentuk tulisan naskah, apakah seperti penulisan cerita pada umumnya,

Iluminasi, yakni hiasan bingkai yang biasanya terdapat pada halaman awal dan mungkin juga pada halaman akhir; dan ilustrasi, yaitu hiasan yang mendukung teks. 
ataukah berbentuk kolom-kolom hingga dalam satu halaman bisa terdapat dua atau lebih kolom tulisan (seperti syair).

Selanjutnya, kita mengecek garis bantuan yang digunakan untuk mengatur tulisan, cap kertas ${ }^{7}$ (watermark dan countermark) yang menandai perusahaan penghasil kertas alas, ada atau tidaknya iluminasi (hiasan di pinggir naskah) dan ilustrasi (bagian yang berisikan gambar keterangan yang menjelaskan sesuatu dalam naskah). Perlu dicatat kerusakan-kerusakan yang ada.

Informasi mengenai pengarang, penyalin, tempat, dan tanggal penulisan atau penyalinan naskah dapat diketahui dari adanya kolofon pada naskah tersebut. Kolofon tersebut biasanya terdapat pada halaman judul, sebelum awal teks atau pada akhir teks. Kadang kolofon ini ditambah dengan anjuran agar pembaca berhati-hati memperlakukan naskahnya, bahkan ada pula yang mencantumkan sewa dan harga naskah (S.W.R. Mulyadi, 1994:3843).

\section{Wilayah, Tim, dan Jumlah Naskah}

Katalog naskah tasawuf ini menyajikan naskah-naskah tasawuf yang berhasil diinventarisasi dan dikoleksi dari berbagai lembaga dan perorangan yang tersebar di enam (6) propinsi, yaitu: Propinsi Aceh dikumpulkan oleh H. Saeful Bahri, S.Ag; Propinsi Sumatera Barat dikumpulkan oleh Zulkarnain Yani, S.Ag., MA.Hum; Propinsi Sumatera Utara dikumpulkan oleh H. Ahmad Khalid Dawam, Lc., M.Hum dan Syarif, S.Sos; Propinsi Sumatera Selatan dikumpulkan oleh Muhammad Tarobin, S.Sos; Propinsi Banten dikumpulkan oleh Muhamad Rosadi, S.Ag., MA; serta Propinsi Jawa Barat dikumpulkan oleh Dr. H. Harapandi Dahri, M.Ag.

Adapun pemilihan ke enam (6) propinsi di atas karena: Pertama, merupakan wilayah kerja Balai Litbang Agama Jakarta, dan kedua, berdasarkan data dari berbagai katalog naskah yang ada dan juga hasil studi awal atau penjajakan yang dilakukan,

${ }^{7}$ Cap kertas adalah semacam gambar pada kertas, dapat kita lihat dengan nyata ditempat yang ada sinar matahari atau lampu. 
ke enam (6) propinsi tersebut menyimpan dan memiliki naskah tasawuf yang cukup banyak setelah naskah fiqih yang tersebar di berbagai tempat tentunya.

Berdasarkan hasil inventarisasi naskah-naskah tasawuf yang tersebar di sejumlah koleksi, tim peneliti berhasil mengumpulkan naskah tasawuf sebanyak 280 naskah/teks dengan rincian sebagai berikut:

\begin{tabular}{|c|c|c|}
\hline No & Propinsi/Koleksi & Jumlah Naskah \\
\hline 1 & $\begin{array}{l}\text { Propinsi Aceh: } \\
\text { Koleksi Museum Negeri Aceh }\end{array}$ & 65 \\
\hline 2 & $\begin{array}{l}\text { Propinsi Sumatera Barat: } \\
-\quad \text { Koleksi Suluah Community } \\
\text { - } \quad \text { Koleksi Syofyan Hadi }\end{array}$ & $\begin{array}{l}65 \\
26\end{array}$ \\
\hline 3 & $\begin{array}{l}\text { Propinsi Sumatera Utara: } \\
\text { Koleksi Museum Negeri Sumatera Utara }\end{array}$ & 30 \\
\hline 4 & $\begin{array}{l}\text { Propinsi Sumatera Selatan: } \\
-\quad \text { Koleksi Kms. H. Andi Syarifuddin, S.Ag } \\
-\quad \text { Koleksi Nyimas Ummi Kulsum } \\
\text { - } \quad \text { Koleksi Mgs. H. Aminuddin }\end{array}$ & $\begin{array}{c}25 \\
3 \\
1\end{array}$ \\
\hline 5 & $\begin{array}{l}\text { Propinsi Banten: } \\
\text { - } \quad \text { Koleksi Balai Pelestarian Peninggalan } \\
\text { Purbakala dan Sejarah Serang } \\
\text { - } \quad \text { Koleksi Tabrani, Kampung Gagas Selawe, } \\
\text { Desa Onyam, Kecamatan Gunung Kaler } \\
\text { - } \quad \text { Koleksi Tanjib, Desa Tersaba, Kecamatan } \\
\quad \text { Tanara, Kabupaten Serang } \\
\text { - } \quad \text { Koleksi Dimyati, Kampung Gembong, Desa } \\
\quad \text { Gembong, Kecamatan Balaraja } \\
\text { - } \quad \text { Koleksi Atiqoh, Kampung Gelereng, Desa. } \\
\text { Gelereng, Kecamatan Ciwandan, Kota } \\
\quad \text { Cilegon } \\
\text { - } \\
\text { Koleksi Julita, Kampung Sumur Lubang, Desa } \\
\text { Salira, Kecamatan Pulo Ampel } \\
\text { - } \quad \text { Koleksi Hikmat, Kampung/Desa Kresek, } \\
\text { Kecamatan Kresek, Kabupaten Tangerang } \\
\text { - Koleksi KH. Tadjuddin, Kampung Cikeles, } \\
\text { Desa Cipanas, Lebak Ranakasbituna }\end{array}$ & $\begin{array}{l}1 \\
2 \\
1 \\
3\end{array}$ \\
\hline
\end{tabular}




\begin{tabular}{|c|l|c|}
\hline & $-\quad$ Koleksi KH. Mas Sulaiman, Madrasah AI- & 1 \\
& $-\quad$ Khaeriyyah Kecamatan Pontang \\
\hline \multirow{2}{*}{ Koleksi H. Madnadir, Kalapiyan, Serang } & 1 \\
\hline & Propinsi Jawa Barat: & 10 \\
& $-\quad$ Koleksi drh. R.H. Bambang Irianto, BA & 4 \\
& $-\quad$ Koleksi Edwin Sujana & 14 \\
& $-\quad$ Koleksi Elang Hilman & 15 \\
\hline \multicolumn{2}{|c}{ Koleksi Keraton Kacirebonan } & 7 \\
\hline
\end{tabular}


Bab 1: Pendahuluan

[14] 


\title{
2 \\ Kaleksi dan Katalogisasi \\ NASKAH TASAWUF DI PROPINSI ACEH "Koleksi Museum Negeri Aceh"
}

\author{
Oleh: \\ Saeful Bahri
}

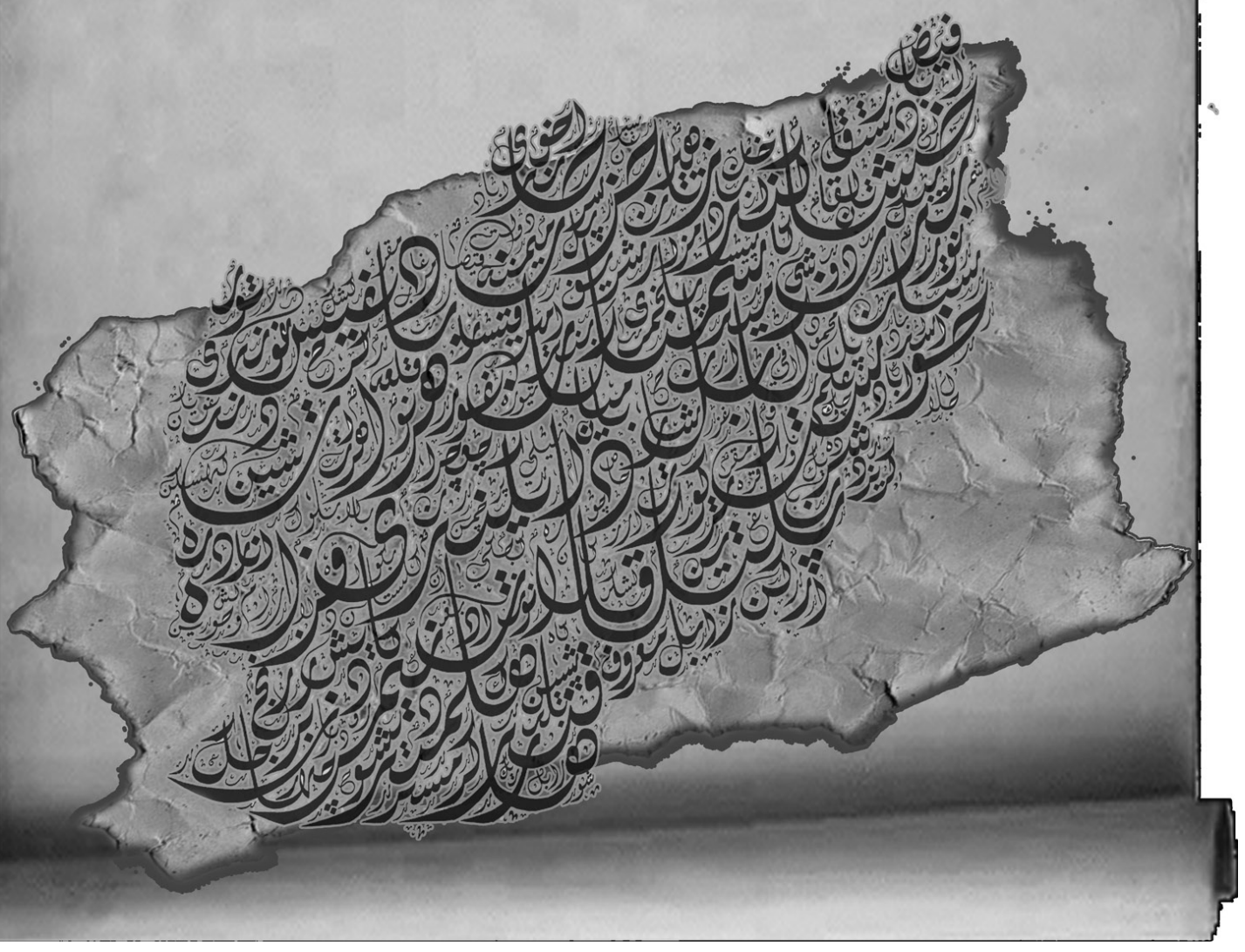




\section{Sair al-Salikin ila 'Ibadat Rabb al-'Alamin}

00/TS/MNA-677/2012

Kertas Eropa
Jawi

$22.3 \times 16 \mathrm{~cm}$
Prosa

$15.2 \times 9.2 \mathrm{~cm}$
$274 \mathrm{hlm}$

$11 \mathrm{baris} / \mathrm{hlm}$

\section{Pengarang}

'Abd as-Shamad al-Jawi al-Palimbani

\section{Penulisan}

Selesai ditulis di Mekkah pada awal tahun 1194 H (1780 M). Penanggalan ini sesungguhnya terdapat pada bagian akhir teks Kitab Sair al-Salikin oleh pengarang sendiri 'Abd as-Shamad al-Jawi al-Palimbani. Selesai disalin kitab ini Haji Abd Hamid di Mekkah, hari Ahad pada bulan Zulqa'dah.

\section{Kolofon}

Qad faragha min tarjamah hadha al-kitab awwal sanat wa-mi'at wa-arba' wa-tis'in fi makkah al-musyarrafah 'ala yad tarjumatihi alfaqir ila Allah Ta'ala 'Abd as-Shamad al-Jawi al-Palimbani ghafarallah lahu waliwalidaihi wa-limasyeikhi wa al-muslimin. Artinya: selesai daripada menterjemahkan akan kitab ini pada awal tahun Seribu Seratus Sembilan puluh empat tahun dalam Makkah Musyarrafah atas tahun yang menerjemahkan akan dia, yaitu Faqir ila Allah Ta'ala 'Abd as-Shamad al-Jawi al-Palimbani, mudah-mudahan dihimpunkan Allah Ta'ala baginya dan bagi ibu bapaknya dan segala Syeikhnya dan bagi muslimin. Amin ya Rabb al-'alamin.

Tamat kitab pada waktu Dhuha pada hari Ahad pada negeri Makkah Musyarrafah pada bulan Zulqaiddah, menyurah dia Haji 'Abd Hamid. Wallahu a'lam bi al-ahawab.

\section{Cap Kertas}

Bulan Sabit Bersusun Tiga (Venice, 1725 M) 


\section{Gambaran Isi}

Sebagaimana biasanya karya klasik ulama nusantara terdahulu, kandungan ini kitabnya interdisipliner ilmu. Karena itu, pada dasarnya naskah Sair al-Salikin dapat dikategorikan ke tasawuf, ibadah, dan akhlak. Pembahasan masalah-masalah fiqih dan ibadah dalam teks dikemukakan dalam perspektif tasawuf.

Naskah ini terdiri dari empat Juz (aqsam) dan penutup, sebagaimana yang disebut oleh pengarang di awal penulisan kitabnya. Setiap Juz dibagi kepada sepuluh bab, yang masing-masing bab terdiri dari beberapa pasal.

Juz yang pertama menyatakan ilmu ushuluddin, yaitu ilmu i'tikad Ahl al-Sunnah wa al-Jamaah dan yang taat.

Juz kedua tentang adab, yaitu hukum adab (kesopanan) yang berlaku seperti makan, minum, kawin, usaha kehidupan di dunia, halal dan haram, bersahabat dan uzlah.

Juz ketiga tentang kecelaan, dan juz yang terakhir munjiyat, yaitu melepaskan (menjauhi) diri dari apa yang dapat membinasakan agama. Selanjutnya, pembahasan kitab ini diakhiri dengan penutup (khatimah).

\section{Keterangan}

Naskah ini terjilid rapi dan bersampul kain berwarna merah tua dan bergaris. Ditulis dengan khat naskhi berwarna hitam dan rubrikasi merah. Tidak ada penomoran teks, dan setiap halaman terdapa alihan kata di bawah matan teks. Sedangkan penomoran aksara latin terjadi dua kali, yaitu di bagian atas tengah dan di samping atas. 


\section{Mir'al al-'Arifin}

$\begin{array}{cccc}\text { 00/TS/MNA-1114/2012 } & \text { Arab } & \text { Prosa } & 134 \mathrm{hlm} \\ \text { Kertas Eropa } & 23 \times 16 \mathrm{~cm} & 14.5 \times 8 \mathrm{~cm} & 17 \mathrm{baris} / \mathrm{h} / \mathrm{m}\end{array}$

Pengarang

Penulisan

Kolofon

\section{Cap Kertas}

Bulan sabit tersenyum bersusun tiga

\section{Gambaran Isi}

Naskah ini merupakan teks yang membahas tentang bahasan tasawuf, di antara isinya tentang hakikat wujud, langkah-langkah menuju kebenaran, orang alim, ahlu kasyaf, ubudiyyah, dan lainlain.

\section{Keterangan}

Naskah dijilid dengan kain tenun, kondisi fisik naskah tergolong baik, masih bisa terbaca walaupun sebagiannya berlobang dimakan serangga. 


\section{Qawa'id al-Islam}

00/TS/MNA-812/a/2012

Aceh

Prosa

$31 \mathrm{hlm}$

Kertas Eropa

$22 \times 16 \mathrm{~cm}$

$14.5 \times 8 \mathrm{~cm}$

17 baris/hlm

\section{Pengarang}

\section{Penulisan}

\section{Kolofon}

\section{Cap Kertas}

Bulan sabit tersenyum bersusun tiga

\section{Gambaran Isi}

Naskah ini merupakan teks yang membahas tentang bahasanbahasan syahadat, sifat wajib Allah 20, sifat mustahil, dan pembagiannya.

\section{Keterangan}

Ciri khas dari penulisan teks naskah ini terlihat dari cara menulis Bismi-Allah yang diselingi dengan tanda titik-titik antara huruf $\mathrm{Ba}$ Sin dengan huruf Mim. Ada beberapa naskah lainnya yang memiliki ciri khas tersebut.

Apabila ditinjau dari oxordium naskah, maka kemungkinan besar naskah ini terjemahan dan kitab Arab atau Jawi, karena dipembukaannya hingga sampai pada judul kitab menunjukkan karakter penulisan kitab Jawi atau Arab, bukan kitab berbahasa Aceh. 


\section{Ushul al-Din}

$\begin{array}{cccc}\text { 00/TS/MNA-812/b/2012 } & \text { Aceh } & \text { Prosa } & 10 \mathrm{hlm} \\ \text { Kertas Eropa } & 22 \times 16 \mathrm{~cm} & 13.5 \times 8 \mathrm{~cm} & 14 \mathrm{baris} / \mathrm{hlm}\end{array}$

\section{Pengarang}

\section{Penulisan}

\section{Kolofon}

Pikir olehmu akan ayat Allah dan jangan kamu piker akan dzat Allah. Wa Shallallahu 'ala khairi khalqihi Muhammad wa-alihi wa-shahbihi wa-sallam. Tammat al-kitab Ushul al-Din, Amin. Amin.

\section{Cap Kertas}

Bulan sabit tersenyum bersusun tiga

\section{Gambaran Isi}

Naskah ini merupakan teks berbahasa Aceh, kajiannya mendasar tentang Qudrah dan Iradah Allah dan usaha dan takdir manusia di dunia ini. yang membahas tentang bahasan-bahasan tasawuf, di antara isinya tentang hakikat wujud, jalan-jalan menuju kebenaran, orang alim, ahlu kasyaf, ubudiyyah, dan lain-lain.

\section{Keterangan}

Judul naskah ini disebutkan di akhir tulisan atau di kolofon sebagaimana tersebut di atas. Naskah ini koleksi Museum Negeri Aceh, sesuai kandungannya naskah ini lengkap dan kondisi fisik naskah juga terpelihara, teksnya terbaca. Setiap halaman memiliki alihan kata, ditulis dengan khat naskhi, warna teks hitam, kecuali rubrikasi menggunakan tinta berwarna merah. 
[Sifat 20]

No. $07.812 / \mathrm{c} /$

Kertas Eropa
Aceh

$22 \times 16 \mathrm{~cm}$
Prosa

$16.5 \times 8,5 \mathrm{~cm}$
$3 \mathrm{hlm}$

21 baris/hlm

\section{Pengarang}

\section{Penulisan}

\section{Kolofon}

\section{Cap Kertas}

Bulan sabit tersenyum bersusun tiga

\section{Gambaran Isi}

Naskah ini merupakan teks berbahasa Aceh yang mengkaji tentang sifat wajib dan mustahil akan Allah, teks menguraikan satu persatu sifat 20 dan diartikan ke dalam bahasa Aceh, seperti "Wujud na Allah, Qadim han tan dilee Allah, Baqa han tan dudoe Allah" [Wujud artinya Allah ada, Qadim artinya Allah pertama, Bawa artinya Allah kekal].

\section{Keterangan}

Judul teks ini terdapat pada urutan ketiga dari sepuluh judul teks yang terkandung di dalam naskah. Naskah ini masih terjilid dan bersampul warna kecoklatan, di halaman awal naskah terdapat halaman kosong. Jika merujuk kepada kolofon dari akhir judul teks, bahwa naskah ini disalin berkisar tahun 1285 H (1868 M). 


\begin{tabular}{cccc}
\multicolumn{4}{c}{ Mafatih al-Ghuyub bi-'Auni al-Mulk al-Ma'bud } \\
00/TS/MNA-812/d/2012 & Jawi & Prosa & $12 \mathrm{hlm}$ \\
Kertas Eropa & $22 \times 16 \mathrm{~cm}$ & $16.5 \times 8 \mathrm{~cm}$ & $19 \mathrm{baris} / \mathrm{hlm}$
\end{tabular}

\section{Pengarang}

Penulisan

\section{Kolofon}

Tammat kitab Mafatih al-'Ghuyub, yakni Anak Kunci daripada segala aib-aib. Tamat kalam bil-khair. Tuhanku Rabb qabul minna.

\section{Cap Kertas}

Bulan sabit tersenyum bersusun tiga

\section{Gambaran Isi}

Naskah ini merupakan teks berbahasa Jawi yang menguraikan tentang alam arwah, alam jiwa, alam insan, martabat-martabat manusia, di antaranya: martabat tujuh, ahadiyah, wahdah, wahidiyah, alim mitsal, alim ajsam, alam insan.

Isi kandungan teks naskah juga menjelaskan makna dari bacaan surat Umm Al-Qur'an bagi mereka yang menjalani tatacara pelaksanaan tarekat (tasawuf) dalam martabat Ahadiyah. Selanjutnya disebutkan keutamaan zikir dan ucapan-ucapan yang diucapkan, dan yang paling besar pahalanya adalah kalimat La ilaha illa Allah. Disebutkan "Maka dari itu kalimat La ilaha illa Allah itu dua belas huruf, maka kalimat dua belas itu terhimpun ia pada empat kalimat; pertama kalimat $L a$, kedua kalimat ilah, ketiga kalimat illa, keempat kalimat Allah". 


\section{Keterangan}

Judul teks ini terdapat pada urutan ke empat dari sepuluh judul teks yang terkandung di dalam naskah. Naskah ini masih terjilid dan bersampul warna kecoklatan, di halaman awal naskah terdapat halaman kosong. Jika merujuk kepada kolofon dari akhir judul teks bahwa naskah ini disalin berkisar tahun 1285 H (1868 M).

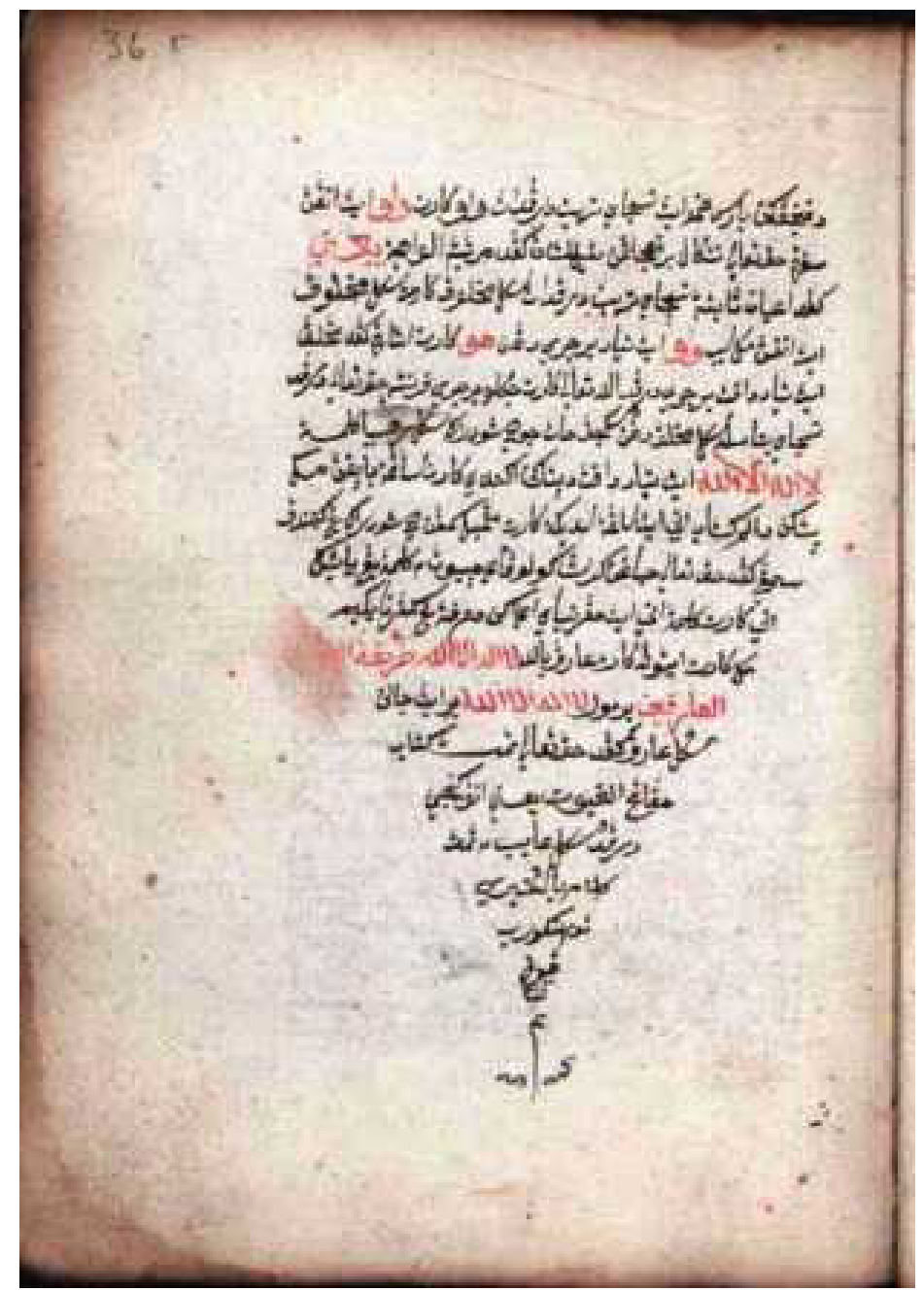

Kolofon naskah Mafatih al-Ghuyub bi-'Auni al-Mulk al-Ma'bud 


\author{
Mafatih al-Ghuyub bi-'Auni al-Mulk al-Ma'bud \\ 00/TS/MNA-376/2012 \\ Jawi \\ Prosa \\ $7 \mathrm{hlm}$ \\ Kertas Eropa \\ $22.5 \times 16 \mathrm{~cm}$ \\ $16 \times 10 \mathrm{~cm}$ \\ $19 \mathrm{baris} / \mathrm{hlm}$
}

\title{
Pengarang
}

\section{Penulisan}

\section{Kolofon}

\section{Cap Kertas}

Bulan Sabit bersusun tiga tidak sejajar (Tahun 1823)

\section{Gambaran Isi}

Naskah ini merupakan teks berbahasa Jawi yang menguraikan tentang alam arwah, alam jiwa, alam insan, martabat-martabat manusia, di antaranya: martabat tujuh; ahadiyah, wahdah, wahidiyah, alim mitsal, alim ajsam, alam insan.

Isi kandungan teks naskah juga menjelaskan makna dari bacaan surat Umm Al-Qur'an bagi mereka yang menjalani tatacara pelaksanaan tarekat (tasawuf) dalam martabat ahadiyah. Selanjutnya disebutkan keutamaan zikir dan ucapan-ucapan yang diucapkan, dan yang paling besar pahalanya adalah kalimat $L a$ ilaha illa Allah.

\section{Keterangan}

Teks naskah ini tidak lengkap di bagian akhir, bahkan halaman teks akhir judul naskah ini tergabung (terjilid) dengan teks lainnya dalam satu bundel. Perbedaan tersebut jelas terlihat dari sisi kondisi kertasnya. 


\begin{tabular}{cccc}
\multicolumn{4}{c}{ Asrar al-Din Ahl al-Yaqin } \\
00/TS/MNA-812/e/2012 & Jawi & Prosa & $17 \mathrm{hlm}$ \\
Kertas Eropa & $22 \times 16 \mathrm{~cm}$ & $16.5 \times 8 \mathrm{~cm}$ & $19 \mathrm{baris} / \mathrm{hlm}$
\end{tabular}

\section{Pengarang}

Muhammad bin Ahmad Khatib Langgien atau dikenal sebagai Teungku Muhammad Khatib Langgien, seorang ulama asal Langgien, Lueng Putu, Pidie.

\section{Penulisan}

\section{Kolofon}

\section{Cap Kertas}

Bulan sabit tersenyum bersusun tiga

\section{Gambaran Isi}

Naskah ini merupakan teks berbahasa Jawi yang mengupas tentang rukun Islam dan rukun Iman dari sisi tasawuf, hakikat dari kepercayaan dan peribadatan yang dilakukan oleh manusia kepada Tuhannya.

"Bermula Islam itu tiga perkara, pertama Islam pada syariat, Kedua Islam pada tarekat dan ketiga Islam pada hakikat...., Bermula Iman itu tiga perkara, pertama iman pada syariat, kedua iman pada tarekat, dan ketiga imannya pada hakikat".

\section{Keterangan}

Judul teks ini terdapat pada urutan kelima dari sepuluh judul teks yang terkandung di dalam naskah. Naskah ini masih terjilid dan bersampul warna kecoklatan, di halaman awal naskah terdapat halaman kosong. Jika merujuk kepada kolofon dari akhir judul teks bahwa naskah ini disalin berkisar tahun $1285 \mathrm{H}$ (1868 M). 


\section{Syifa' al-Qulub}

00/TS/MNA-506/a/2012

Kertas Eropa

$\begin{array}{ccc}\text { Jawi } & \text { Prosa } & 5 \mathrm{hlm} \\ 22 \times 16 \mathrm{~cm} & 17 \times 8 \mathrm{~cm} & 17 \mathrm{baris} / \mathrm{hlm}\end{array}$

\section{Pengarang}

Nur al-Din bin 'Ali bin Hasanji Muhammad Hamid ar-Raniri

\section{Penulisan}

\section{Kolofon}

\section{Cap Kertas}

\section{Gambaran Isi}

Teks ini merupakan kritikan Nuruddin terhadap penyalah tafsiran kalimat La ilaha illa Allah oleh kelompok Wujudiyah. Dalam mukaddimahnya, ia menyatakan "maka tatkala kulihat diubahkan kaum Wujudiyah akan makna La ilaha illa Allah itu serta dihelanya kepada itikad yang sesat". Teks ini adalah melengkapi beberapa risalah (kitab) sederhana dan tipis yang dikarang oleh Nuruddin ar-Raniry atas konsistensinya terhadap persekusi kelompok Wujudiyah.

\section{Keterangan}

Naskah tidak memiliki sampul, namun masih terjilid. Naskah ini terdiri dari beberapa kumpulan teks naskah, ditulis dengan jenis khat naskhi menggunakan tinta hitam, dan rubrikasi warna merah. Pada judul terakhir terdapat perbedaan karakter tulisan dari teksteks sebelumnya. 


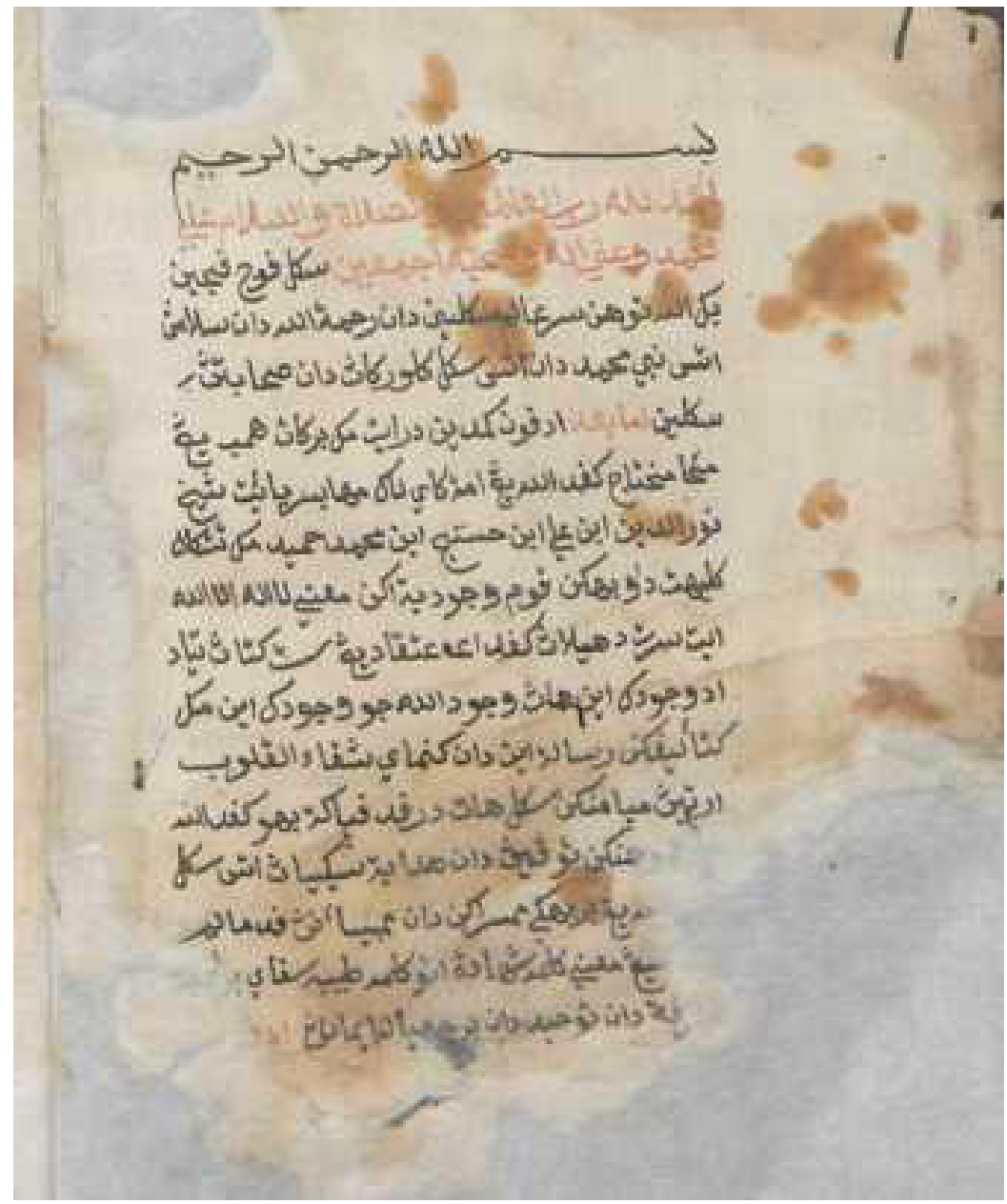

Halaman awal teks Naskah Syifa' al-Qulub 


\begin{tabular}{cccc}
\multicolumn{4}{c}{ Asrar al-Suluk ila Malak al-Mulk } \\
00/TS/MNA-506/b/2012 & Jawi & Prosa & $99 \mathrm{hlm}$ \\
Kertas Eropa & $22 \times 16 \mathrm{~cm}$ & $16 \times 7,5 \mathrm{~cm}$ & $15 \mathrm{baris} / \mathrm{hlm}$
\end{tabular}

Pengarang

Abdurrauf bin 'Ali al-Jawi al-Fansuri

Penulisan

\section{Kolofon}

\section{Cap Kertas}

\section{Gambaran Isi}

Awal pembahasan teks naskah ini tentang sifat-sifat Allah, selanjutnya bab tasawuf; martabat dalam tasawuf, martabat manusia, alam Ilahi, makna zikir, adab zikir. Bab tashghir, bab nisbah, bab jam'i, bab ta'alum, bab niat dan kemudian disebutkan beberapa tata cara shalat, terutama keutamaan shalat sunnah qabliyah dan ba'diyah, tahajjud, dan doa-doa.

Pada penutup kitab disebutkan sanad silsilah Abdurrauf dalam tarekat Syattariyah dan Qadiriyah. Ini menunjukkan data penting hubungan antara nusantara dengan jazirah Arab, bahkan beberapa tarekat lainnya seperti Hamdaniyah dan Naqsyabandiyah memiliki hubungan (muttashil) dengannya.

\section{Keterangan}

Teks naskah ini disalin oleh Teuku Tanjong dan terdapat dua halaman kosong di halaman tengah naskah. 


\section{Syifa' al-Qulub}

00/TS/MNA-506/c/2012

$\begin{array}{ccc}\text { Jawi } & \text { Prosa } & 3 \mathrm{hlm} \\ 22 \times 16 \mathrm{~cm} & 17 \times 9 \mathrm{~cm} & 28 \mathrm{baris} / \mathrm{hlm}\end{array}$

Kertas Eropa

$22 \times 16 \mathrm{~cm}$

$17 \times 9 \mathrm{~cm}$

baris/hlm

\section{Pengarang}

Nuruddin bin 'Ali bin Hasanji Muhammad Hamid ar-Raniri

\section{Penulisan}

\section{Kolofon}

\section{Cap Kertas}

\section{Gambaran Isi}

Teks ini merupakan kritikan Nuruddin terhadap penyalah tafsiran kalimat La ilaha illa Allah oleh kelompok Wujudiyah. Dalam mukaddimahnya, ia menyatakan "maka tatkala kulihat diubahkan kaum Wujudiyah akan makna La ilaha illa Allah itu serta dihelanya kepada i'tikad yang sesat". Teks ini adalah melengkapi beberapa risalah (kitab) sederhana yang dikarang oleh Nuruddin ar-Raniry atas konsistensinya terhadap persekusi kelompok Wujudiyah.

\section{Keterangan}

Judul dan kandungan isi naskah ini sama dalam satu bundel dengan teks pertama. Teks ini ditulis dalam ukuran lebih kecil dan rapi, mudah dibaca, dan jelas. Sedangkan keterangan singkat ditulis sebagai catatan tambahan diluar matan teks atau setelah kolofon teks naskah "Shahibuhu Hasan ibn Musa ibn Teungku di Blang Drang mewakafkan kitab ini kepada sekalian anak hingga cucunya dengan bertali-tali sebagai yang ada berilmunya". 
['Aqa'id al-Iman]

00/TS/MNA-578/a/2012

Arab

Prosa

$22 \mathrm{hlm}$

Kertas Eropa

$22.5 \times 16 \mathrm{~cm} \quad 14 \times 9 \mathrm{~cm}$

7 baris/hlm

\section{Pengarang}

\section{Penulisan}

\section{Kolofon}

Tamat kitab hari Isnain pada waktu Dhuha

\section{Cap Kertas}

Bulan Sabit Tersenyum Bersusun Tiga

\section{Gambaran Isi}

Naskah ini dalam bahasa Arab diterjemahkan berbaris dalam bahasa Melayu, teks naskah mengurai tentang sifat-sifat Allah yang disebut hukum aqli dibagi kepada 3 bagian, yaitu wajib, mustahil (istihalah), dan jaiz (jawaz) akan sifat Allah. Kemudian di dalamnya dijelaskan ke beberapa bagian, yaitu nafsiyah, salbiyyah, dan maknawiyyah.

\section{Keterangan}

Terdapat ilustrasi di halaman awal dan di halaman akhir (kolofon) berbentuk floral dan ciri bentuk khas Aceh dengan warna merah dan hitam, kemudian terdapa tulisan La ilaha illa Allah, Bismillahirrahmanirrahim. 


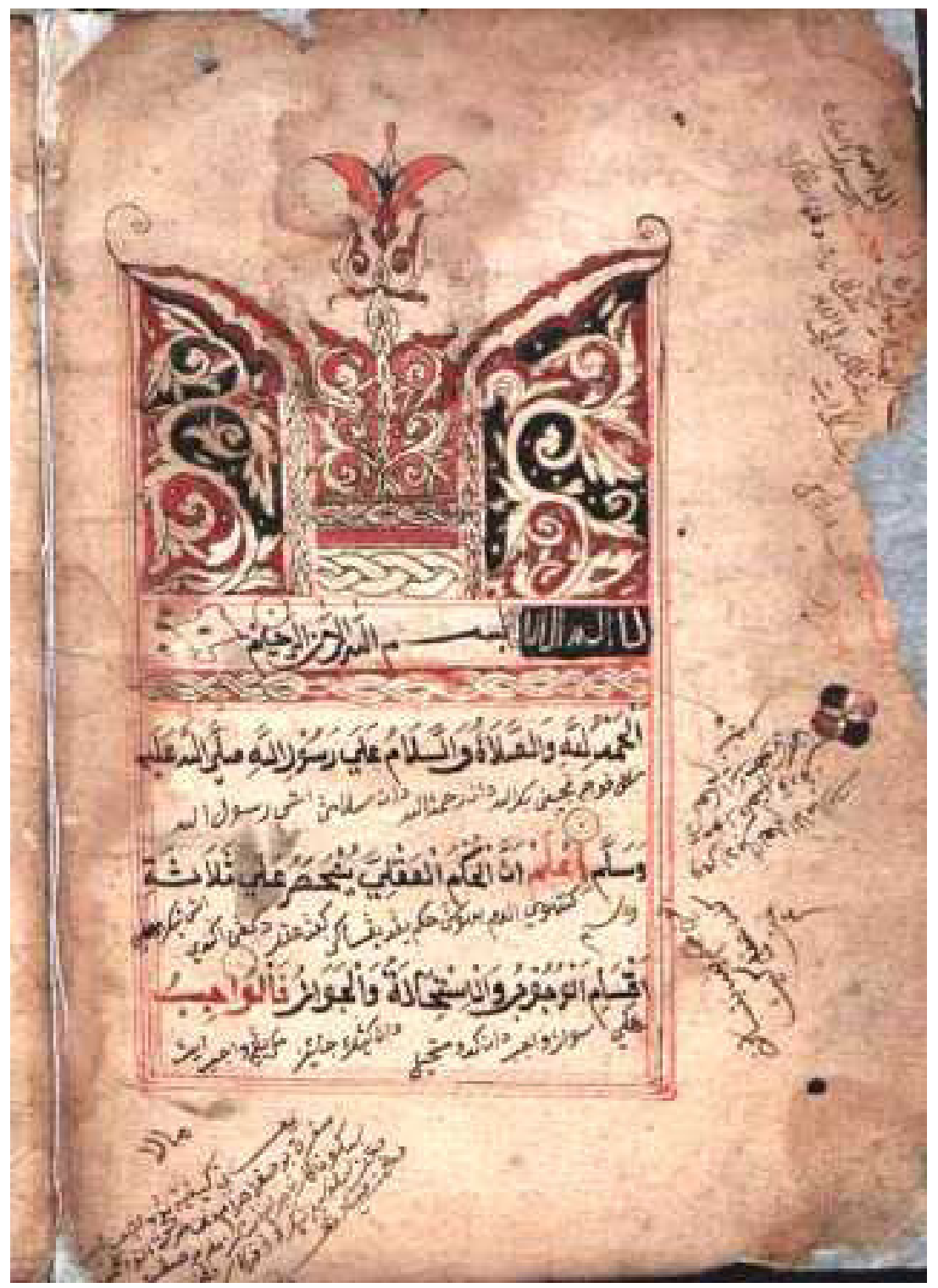

Halaman awal naskah 'Aqa'id al-Iman 


\section{Qawa'id al-Islam}

00/TS/MNA-578/c/2012

Aceh

Prosa

$31 \mathrm{hlm}$

Kertas Eropa

$22.5 \times 16 \mathrm{~cm}$

$14.5 \times 9 \mathrm{~cm}$

17 baris/hlm

\section{Pengarang}

\section{Penulisan}

\section{Kolofon}

\section{Cap Kertas}

Bulan sabit tersenyum bersusun tiga

\section{Gambaran Isi}

Naskah ini merupakan teks yang membahas tentang bahasanbahasan syahadat, sifat wajib Allah 20, sifat mustahil, jaiz, dan pembagian penjelasannya dalam bahasa Aceh.

\section{Keterangan}

Halaman depan terdapat ilustrasi naskah, sebagian besar hiasan tersebut belum selesai sepenuhnya, karna belum diwarnai. Teks naskah ini sudah tidak lengkap, khususnya halaman akhir. 


\section{Khabar Susi}

00/TS/MNA-834/b/

$\begin{array}{ccc}\text { Aceh } & \text { Prosa } & 38 \mathrm{hlm} \\ 16.5 \times 11 \mathrm{~cm} & 11 \times 7 \mathrm{~cm} & 13 \text { baris } / \mathrm{hlm}\end{array}$

\section{Pengarang}

\section{Penulisan}

\section{Kolofon}

\section{Cap Kertas}

Bulan Sabit Bersusun tiga, tahun 1823-1824 M

\section{Gambaran Isi}

Naskah ini berbahasa Aceh yang diterjemah syarah dari kitab Imam al-Ghazali, mengandung ajakan untuk menuntut ilmu dengan ikhlas agar tidak menyesal di waktu mendatang. Ajakan untuk mengikuti jejak rasul, para anbiya dan ulama agar tidak tersesat. Di dalamnya beberapa konsep tentang mencapai ridha Allah, beberapa zikir dan kalimat tayyibah.

\section{Keterangan}

Naskah ini koleksi Museum Negeri Aceh, sesuai kandungannya naskah ini lengkap dan kondisi fisik naskah juga terpelihara, teksnya terbaca. Naskah ini masih terjilid rapi dan memiliki sampul dari kertas tebal berwarna coklat kehitaman. Setiap halaman memiliki alihan kata, ditulis dengan khat naskhi, warna teks hitam, kecuali rubrikasi menggunakan tinta berwarna merah. 


\section{Kaifiyyat Masuk kepada Zikir Tarekat Haddadiyah}

$\begin{array}{cccc}\text { 00/TS/MNA-344 } & \text { Jawi dan Aceh } & \text { Prosa } & 13 \mathrm{hlm} \\ \text { Kertas Eropa } & 16.8 \times 11.5 \mathrm{~cm} & 13.5 \times 8.5 \mathrm{~cm} & 13 \mathrm{baris} / \mathrm{hlm}\end{array}$

\section{Pengarang}

Muhammad Marhaban

\section{Penulisan}

$1200 \mathrm{H}[1785 \mathrm{M}]$

\section{Kolofon}

Tamat oehno kisah Haddad \# karamat that Qutub Ziya \# yang geukarang Muhammad Marhaban \# Kehinaan dalam donya \# Ulon karang di nanggroe Susoh \# Masa ziarah kubu ayahanda\# Seuribee dua reutoh nibak Hijrah \# lapan peuwo peut... \# Washallahu 'ala Sayyidina Muhammad wa Alihi wa shahbihiihi Wasallam $1200 \mathrm{H}$.

\section{Cap Kertas}

Bulan sabit bersusun tiga (Venice, $1725 \mathrm{M}$ )

\section{Gambaran Isi}

Naskah ini membahas tentang cara-cara dan adab masuk ke dalam zikir pada tarekat Qutb al-Irsyad Habib Abd Allah ibn 'Alawi ibn Muhammad Haddad.

Kemudian disebutkan silsilah tarekat tersebut hingga kepada Nabi Muhammad SAW. Selanjutnya, disebutkan syair tentang kisah alHaddad dalam bahasa Aceh.

\section{Keterangan}

Halaman awal kitab terdapat stempel cap bintang delapan dihiasi bunga, dan di tengahnya tulisan Arab, kurang jelas dan tidak terbaca. Teks naskah berwarna hitam dan rubrikasi berwarna merah. 


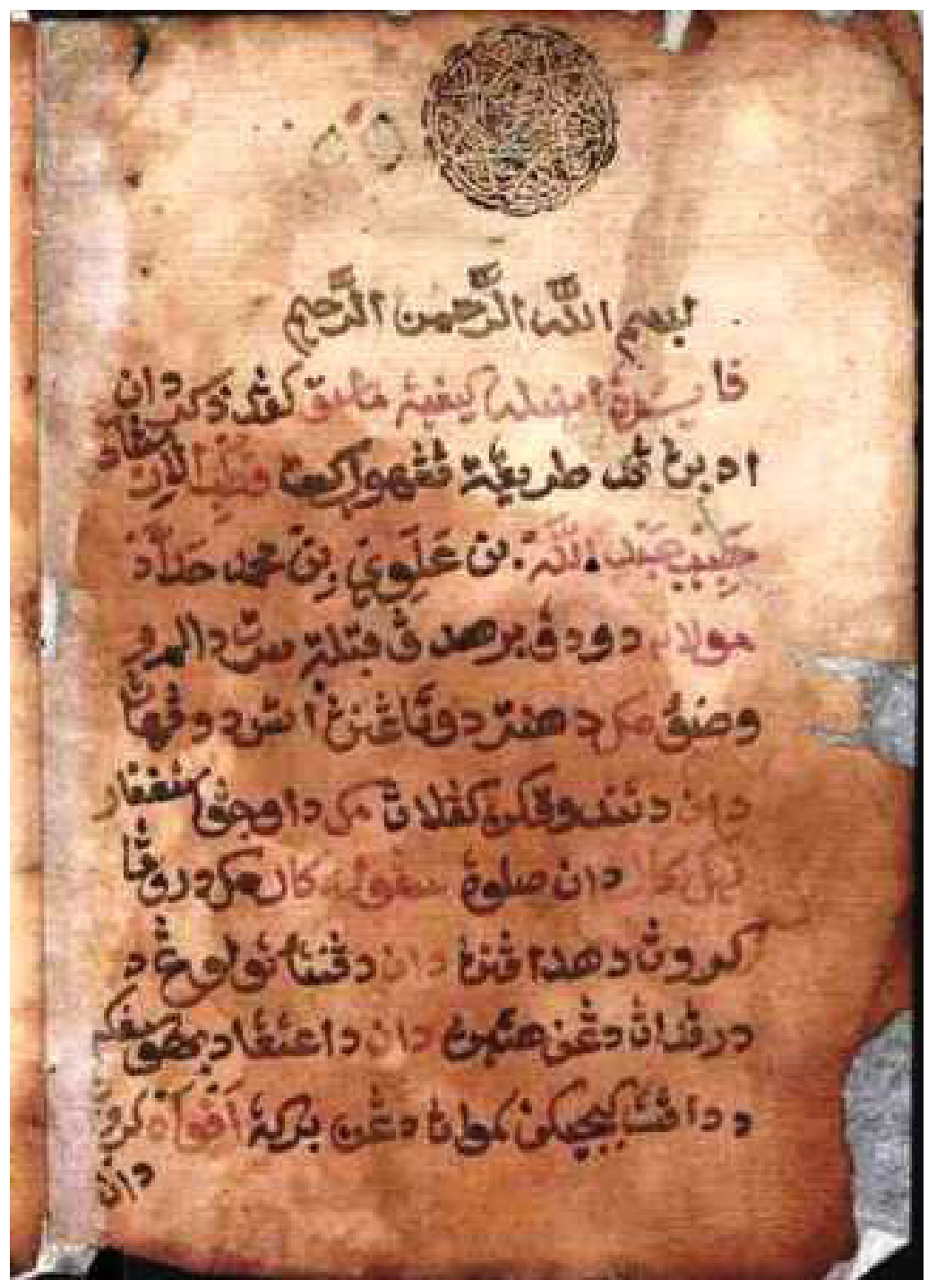

Halaman Awal Kaifiyyat Masuk kepada Zikir 
Kasyf al-Asrar

00/TS/MNA-052/a/

Jawi

Prosa

$132 \mathrm{hlm}$

Kertas Eropa

$25 \times 17 \mathrm{~cm}$

$15 \times 10 \mathrm{~cm}$

19 baris $/ \mathrm{hlm}$

\section{Pengarang}

Syeikh Ibrahim al-Ghani

\section{Penulisan}

Malam Senin, 17 Ramadhan

\section{Kolofon}

Tamma al-kitab al-musamma bi-kasyfi al-asrar fi lailat al-itsnain $f$ syahr ramadhan fi al-sabi' 'asyrata syahr ramadhan.

\section{Cap Kertas}

\section{Gambaran Isi}

Teks ini berbahasa Melayu berisi tentang keesaan Tuhan dan menceritakan juga asal usul keturunan Nabi Muhammad, baik dari pihak bapak maupun dari pihak ibunya. Di samping itu, juga memberi dalil-dalil dari ayat AI-Qur'an tentang sifat-sifat Tuhan.

\section{Keterangan}

Naskah ini koleksi Museum Negeri Aceh, sesuai kandungannya naskah ini lengkap dan kondisi fisik naskah juga terpelihara, teksnya terbaca. Naskah ini masih terjilid rapi dan memiliki sampul dari kertas tebal berwarna coklat kehitaman. Setiap halaman memiliki alihan kata, ditulis dengan khat naskhi, warna teks hitam, kecuali rubrikasi menggunakan tinta berwarna merah. 


\section{[Tasawuf]}

00/TS/MNA-052/b/

Aceh

Prosa

$37 \mathrm{hlm}$

Kertas Eropa

$22.5 \times 16 \mathrm{~cm}$

$14 \times 8.5 \mathrm{~cm}$

19 baris/hlm

\section{Pengarang}

\section{Penulisan}

\section{Kolofon}

\section{Cap Kertas}

\section{Gambaran Isi}

Teks naskah ini berbahasa Aceh yang membahas tentang keeasaan Tuhan, dimulai tentang sifat wajib, jaiz, dan mustahil pada Allah yang diurai secara mendalam secara filosofis. Selanjutnya, membahas tentang mukjizat, ma'unah, karamah, irsyasy, dan ilham.

\section{Keterangan}

Dua halaman terakhirmenyebutkan beberapa hadis Nabi tentang peringatan kepada umat Islam yang meninggalkan shalat, intinya adalah diharamkan bagi mereka yang meninggalkan shalat baik harta, lidah, makanan, minuman, duduk, tidur, bersahabat, tidak dianjurkan berkunjung saat sakit, karena orang meninggalkan shalat telah dilaknat (mal'un). 


\section{Qawa'id al-Islam}

00/TS/MNA-30/a/

Kertas Eropa

\author{
Aceh \\ $21.5 \times 16 \mathrm{~cm}$ \\ Prosa \\ $15 \times 9.5 \mathrm{~cm}$
}

$16 \mathrm{hlm}$

17 baris/hlm

\section{Pengarang}

\section{Penulisan}

Masa Sultan Alaiddin Dhau' Alam Syah bin Sultan Jauhar Alam Dzillullah

\section{Kolofon}

Wa-shahibu hadha al-kitab Teuku Saroeng, wa-'ilmuhu wa-fahmuhu qalil bak loen [pada saya], wa-shallallah 'ala khair Muhammad wa alihi wa-shahbihi wasallam.

\section{Cap Kertas}

Bulan sabit tersenyum bersusun tiga

\section{Gambaran Isi}

Naskah ini merupakan teks yang membahas tentang syahadat, sifat wajib pada Allah, mustahil, jaiz, dan penjelasannya dalam bahasa Aceh.

\section{Keterangan}

Naskah ini terbagi kepada dua teks, pertama Qawaid Islam dan kedua Bidayat al-Mubtadi bi-Ahlillah al-Muhdi. Kedua memiliki persamaan dari bentuk tulisan yang disalin oleh satu orang, yaitu Teungku Sarong di kolofon halaman akhir. 


\section{Al-Syarh al-Mubarak}

$\begin{array}{cccc}\text { 00/TS/MNA-162/a/ } & \text { Arab } & \text { Prosa } & 84 \mathrm{hlm} \\ \text { Kertas Eropa } & 23 \times 16 \mathrm{~cm} & 12 \times 8 \mathrm{~cm} & 11 \text { baris } / \mathrm{hlm}\end{array}$

\section{Pengarang}

\section{Penulisan}

Muharram, 1228 H (1813 M)

\section{Kolofon}

Tamma al-Syarh al-Mubarak bi-'Aunillah al-'Azhim fi al-Sanah Tsamaniyah wa 'Isyruna wa Mi'atain ba'da Alf Syahr al-Muharram $f$ al-zaman seri paduka Sulthan 'Alauddin Jauhar Alam Syah.

\section{Cap Kertas}

\section{Gambaran Isi}

Teks naskah Syarh Mubarak dalam bahasa Arab berisi tentang pembagian hukum akal, yaitu wajib, jaiz, mustahil beserta uraiannya, sifat wajib bagi Allah, dan unsur-unsur akidah lain secara detail di sekitar matan naskah.

\section{Keterangan}

Naskah ini dipenuhi syarah matan di beberapa halaman awal naskah dalam bahasa Arab. Pada kolofon naskah disebutkan, bahwa pemilik dan penulis naskah ini adalah Ja'far Muallim Hitam ibn Abdurrauf Gampong Seulanga di kediaman gurunya Syeikh 'Abdusshamad Lambhuk ibn Yusuf ibn Abdullah al-Fathani. 


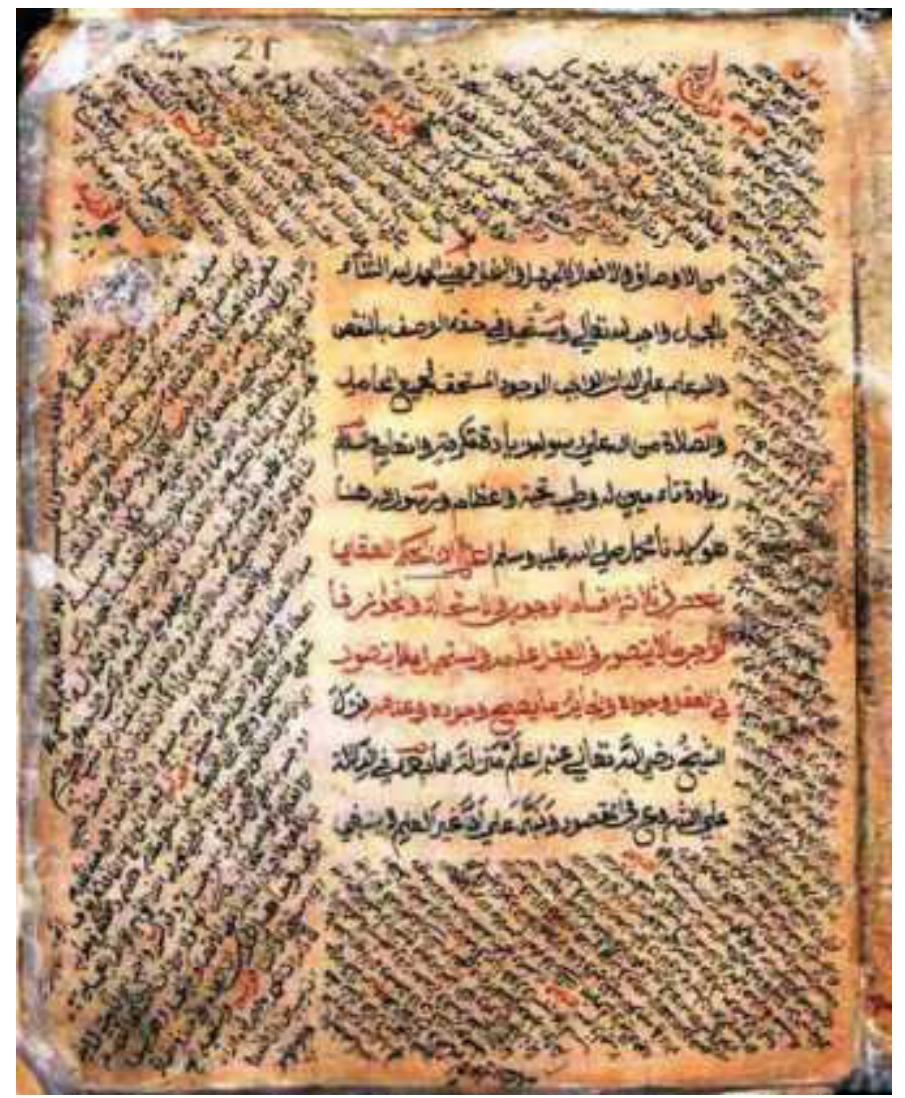

Halaman awal al-Syarh al-Mubarak 


\section{Suluk}

00/TS/MNA-511/a/

$\begin{array}{ccc}\text { Jawi } & \text { Prosa } & 30 \mathrm{hlm} \\ 20,5 \times 15 \mathrm{~cm} & 14 \times 9 \mathrm{~cm} & 17 \mathrm{baris} / \mathrm{hlm}\end{array}$

\section{Pengarang}

\section{Penulisan}

Hari Sabtu waktu Dzuhur, 6 Rajab

\section{Kolofon}

Tammat al-Kitab Suluk pada bulan Rajab pada enam hari bulan Rajab pada hari Sabtu pada waktu Dhuha.

\section{Cap Kertas}

Coat of Arms (1771 M) Edward Heawood, h. 130 no. 826

\section{Gambaran Isi}

Halaman depan naskah initidakada, kandungan isinya menguraikan tentang adab dan sikap seorang guru (syeikh), untuk memperoleh martabat seorang masya'ikh itu dengan meninggalkan kesenangan dan barang-barang yang digemari oleh segala raja-raja dunia. Pada bagian lain terdapat perkataan-perkataan guru sufi sebagai nasihat. Selanjutnya, dibahas tentang hati, zikir, ruh, nur Muhammad, isim zat, isim sifat.

\section{Keterangan}

Naskah ini koleksi Museum Negeri Aceh, sesuai kandungannya naskah ini lengkap dan kondisi fisik naskah juga terpelihara, teksnya terbaca. Naskah ini masih terjilid rapi dan memiliki sampul dari kertas tebal berwarna coklat kehitaman. Setiap halaman memiliki alihan kata, ditulis dengan khat naskhi, warna teks hitam, kecuali rubrikasi menggunakan tinta berwarna merah. 


\begin{tabular}{cccc}
\multicolumn{4}{c}{ Hidayat al-Salikin } \\
fi Suluk Maslak al-Muttaqin \\
00/TS/MNA-.2/2012 & Jawi & Prosa & $171 \mathrm{hlm}$ \\
Kertas Eropa & $21 \times 15 \mathrm{~cm}$ & $15 \times 9 \mathrm{~cm}$ & $17 \mathrm{baris} / \mathrm{hlm}$
\end{tabular}

\section{Pengarang}

Abdusshamad al-Jawi al-Palimbani

\section{Penulisan}

5 Muharram 1192 (3 Februari 1778 M)

\section{Kolofon}

Wa-kana al-faragh min tarjamah hadha al-kitab fi Makkah alMukarramah yaum al-tsalitsun al-khamis min syahr al-haram sanah alf wa-mi'at wa-itsnain watis'ina min hijrat an-Nabi shalla Allah 'alaihi wa-sallam. Dan adalah daripada menterjemahkan akan kitab ini di dalam Makkah al-Musyarrafah pada hari tsalisun yang kelima hari daripada bulan Muharram pada tahun Seribu dan Sembilan Puluh Dua Tahun daripada hijrah Nabi shalla Allah 'alaihi wasallam 'ala sayyidina Muhammad khatim an-nabi wa al-mursalin wa'ala alihi wa-shahbihi ajma'in. Amin, ya rabba al-'Alamin. Amin.

\section{Cap Kertas}

VG, tahun $1820 \mathrm{M}$

\section{Gambaran Isi}

Pembahasan dalam kitab ini merupakan gabungan antara ajaranajaran fiqih dan tasawuf, dengan mengikuti ajaran Imam al-Ghazali. Kitab ini terdiri dari beberapa pasal, bab dan faedah. Dua pasal pertama membicarakan kelebihan ilmu yang bermanfaat, dan kelebihan orang yang menuntut ilmu. Kemudian, 7 bab berikutnya tentang dasar-dasar akidah Ahl al-Sunnah wa al-Jamaah; ibadah lahiriah; menjauhi perbuatan maksiat. Selanjutnya disebutkan jenis-jenis perbuatan maksiat batin; jenis ketaatan batin; ajaran 
dan zikir tasawuf; adab orang alim, adab orang belajar, adab anak kepada orang tua, dan adab bersahabat.

\section{Keterangan}

Naskah ini koleksi Museum Negeri Aceh, sesuai kandungannya naskah ini lengkap dan kondisi fisik naskah juga terpelihara, teksnya terbaca. Naskah ini masih terjilid rapi dan memiliki sampul dari kertas tebal berwarna coklat kehitaman. Setiap halaman memiliki alihan kata, ditulis dengan khat naskhi, warna teks hitam, kecuali rubrikasi menggunakan tinta berwarna merah.

Di awal halaman atau pembukaan kitab terdapat iluminasi dengan motif Aceh, dan halaman akhir. 


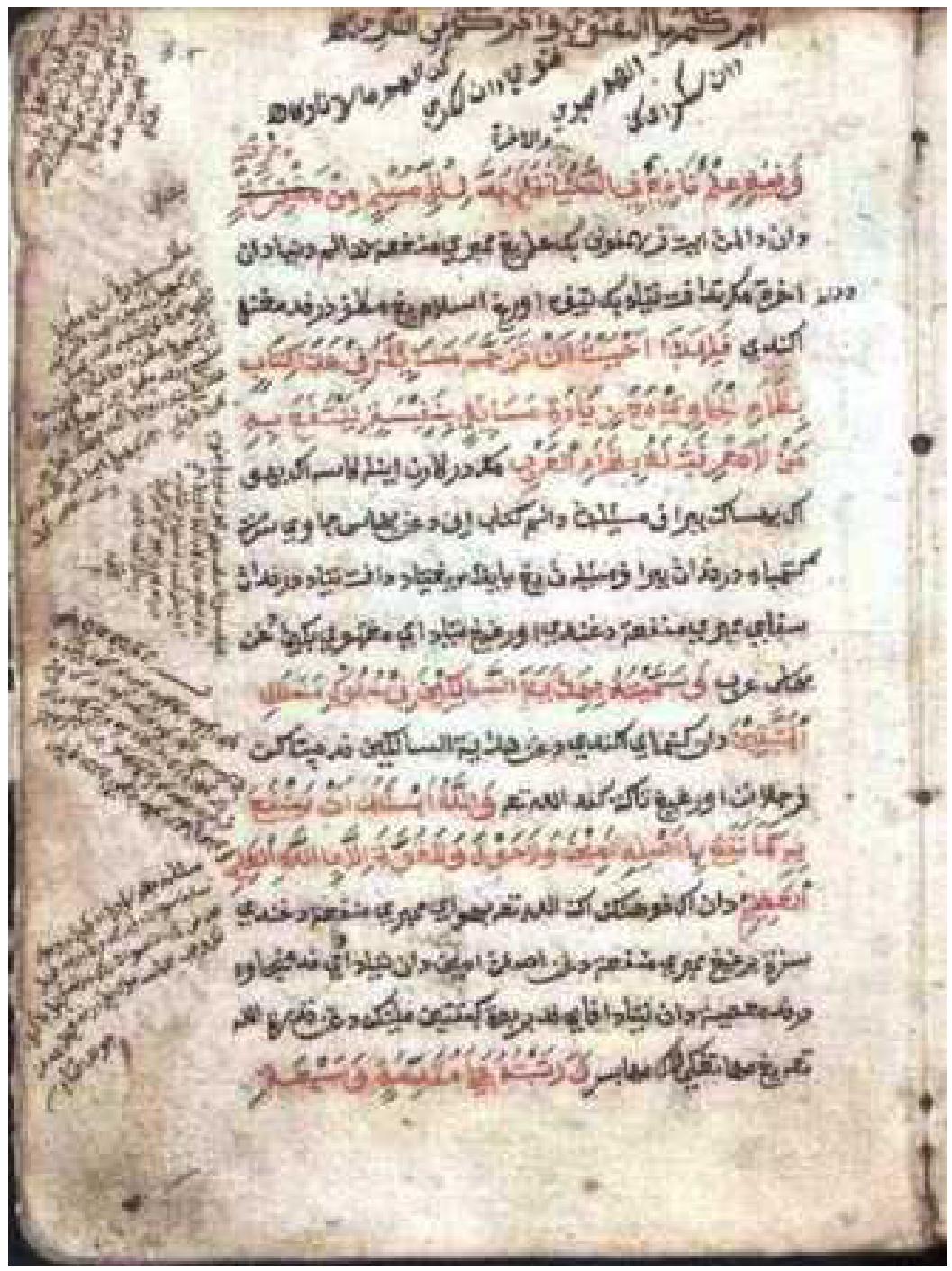

Halaman awal Naskah Hidayat al-Salikin fi Suluk Maslak al-Muttaqin 


\section{Hidayat al-Salikin fi Suluk Maslak al-Muttaqin}

00/TS/MNA-954

Jawi

Prosa

$164 \mathrm{hlm}$

Kertas Eropa

$23 \times 16 \mathrm{~cm}$

$15 \times 9 \mathrm{~cm}$

18 baris/hlm

\section{Pengarang}

Abdusshamad al-Jawi al-Palimbani

\section{Penulisan}

5 Muharram 1192 (3 Februari 1778 M)

\section{Kolofon}

\section{Cap Kertas}

Bulan Sabit Bersusun Tiga, tahun 1823-1824 M (Edward Heawood, h. 139 , no. 880 )

\section{Gambaran Isi}

Pembahasan dalam kitab ini merupakan gabungan antara ajaranajaran fiqih dan tasawuf, dengan mengikuti ajaran Imam al-Ghazali. Kitab ini terdiri dari beberapa pasal, bab dan faedah. Dua pasal pertama membicarakan kelebihan ilmu yang bermanfaat, dan kelebihan orang yang menuntut ilmu. Kemudian, 7 bab berikutnya tentangdasar-dasar akidah Ahl al-Sunnah wa al-Jamaah; ibadah lahiriah; menjauhi perbuatan maksiat. Selanjutnya disebutkan jenis-jenis perbuatan maksiat batin; jenis ketaatan batin; ajaran dan zikir tasawuf; adab orang alim, adab orang belajar, adab anak kepada orang tua, dan adab bersahabat. 


\section{Keterangan}

Naskah ini koleksi Museum Negeri Aceh, sesuai kandungannya naskah ini lengkap dan kondisi fisik naskah juga terpelihara, teksnya terbaca. Setiap halaman memiliki alihan kata, ditulis dengan khat naskhi, warna teks hitam, kecuali rubrikasi menggunakan tinta berwarna merah. 


\section{Al-Thriqah al-Khalwatiyah}

$\begin{array}{cccc}\text { No. 07.1314 } & \text { Jawi \& Aceh } & \text { Prosa\& Nazam } & 32 \mathrm{hlm} \\ \text { Kertas Eropa } & 21 \times 17 \mathrm{~cm} & 19 \times 14 \mathrm{~cm} & 12 \mathrm{baris} / \mathrm{hlm}\end{array}$

\section{Pengarang}

\section{Penulisan}

\section{Kolofon}

\section{Cap Kertas}

\section{Gambaran Isi}

Naskah ini berbahasa Jawi yang berisikan tentang cara-cara berzikir dalam tarekat Khalwatiyyah. Pengarang menjelaskan zikir dimulai dengan membaca "Astaghfiru Allah al-'adzim alladzi la ilaha illa huwa al-hayy al-Qayyum wa atubu ilaihi" sebanyak 3 kali, kemudian baru dilanjutkan dengan bacaan-bacaan lain.

Pada halaman ke tujuh dan seterusnya dimulai dengan nazam berbahasa Arab dan diterjemahkan dalam bahasa Aceh yang berisikan pujian-pujian, ditutup dengan doa.

\section{Keterangan}

Halaman pertama naskah ini terdapat hadis Nabi "Man qala la ilaha illa Allah fi akhiri al-kalam dakhala al-jannah qabla al-hisab". Selanjutnya disebutkan nama-nama Nabi yang wajib diketahui. 


\section{Hidayat al-Muttaqin}

00/TS/MNA-.591/b/

Kertas Bergaris
Jawi

Prosa

$34 \times 20.5 \mathrm{~cm}$

$32 \times 19 \mathrm{~cm}$

$7 \mathrm{hlm}$

$28 \mathrm{baris} / \mathrm{hlm}$

\section{Pengarang}

\section{Penulisan}

\section{Kolofon}

\section{Cap Kertas}

\section{Gambaran Isi}

Menurut pengarang kitab, bahwa ia merujuk kepada perkataan Abdusshamad bin Faqih Husain dalam hal ilmu Salik (Suluk). Kitab ini dibagi kepada lima bab, namun yang terdapat hanya dua bab saja, yaitu; bayan al-ghuflah wa-tafakkur, tentang lalai dan tafakkur; bayan al-'ilm wa al-jahl, tentang ilmu dan jahil. Selanjutnya, penyalin langsung menulis tentang teks naskah Tuhfat al-Mursalah.

\section{Keterangan}

Satu bundel naskah ini terdapat beberapa teks tentang tasawuf, baik dalam bahasa Aceh maupun bahasa Melayu. Akan tetapi, mayoritas di dalamnya tidak memiliki judul, seperti penjelasan makna kalimat La ilaha illa Allah, nazam-nazam tasawuf, zikir-zikir dalam tarekat, penjelasan hadis Nabi man 'arafa nafsahu faqad 'arafa Rabbahu. 


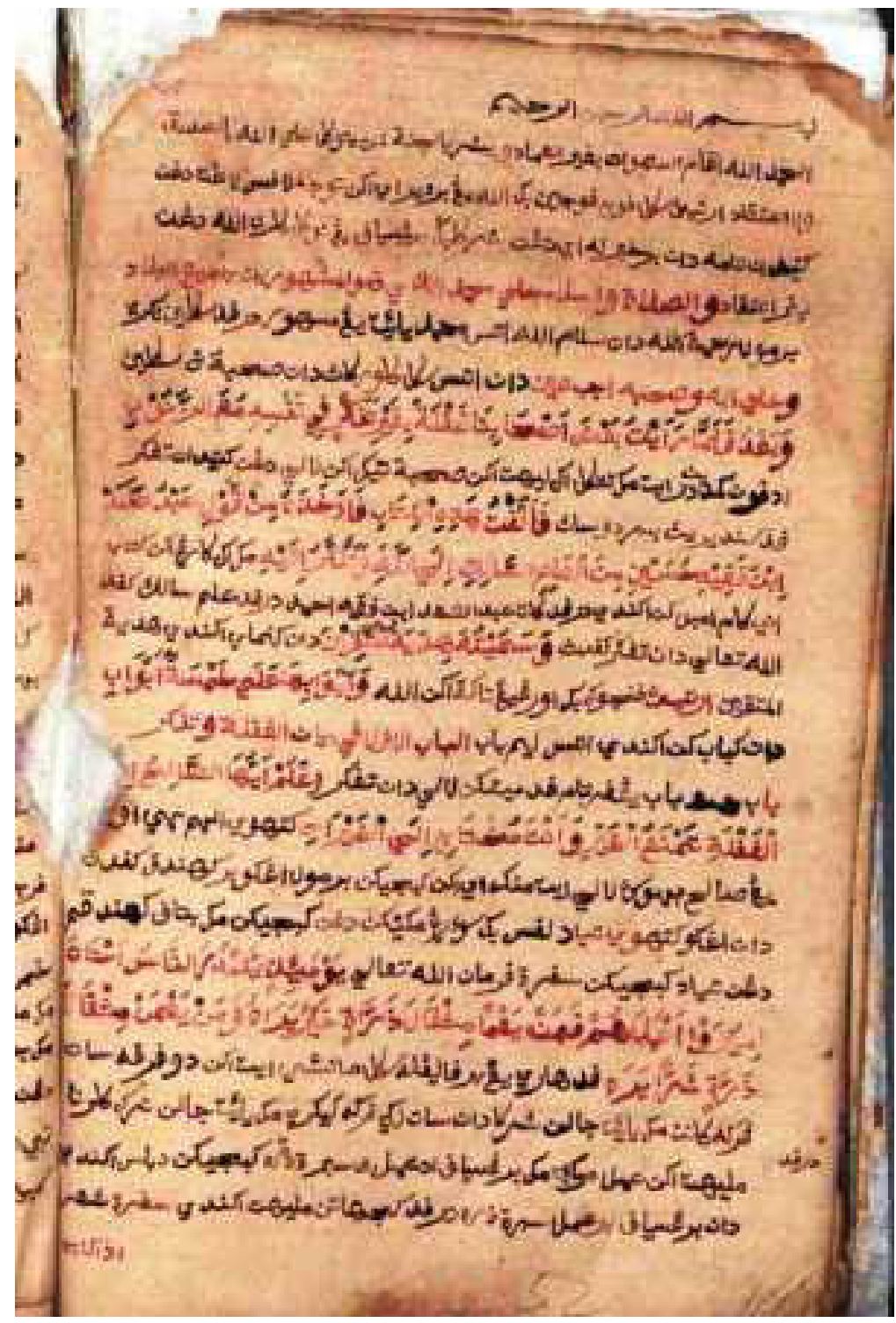

Naskah Hidayat al-Muttaqin 


\section{Al-Mawaidh al-Badi'ah}

00/TS/MNA-.1338/b/

$\begin{array}{ccc}\text { Jawi } & \text { Prosa } & 22 \mathrm{hlm} \\ 22.5 \times 16 \mathrm{~cm} & 17 \times 10 \mathrm{~cm} & 16 \text { baris } / \mathrm{hlm}\end{array}$

\section{Pengarang}

Abdurrauf al-Jawi al-Fansuri

\section{Penulisan}

\section{Kolofon}

\section{Cap Kertas}

Bulan Sabit Tersenyum Dalam Perisai, 1829 M

\section{Gambaran Isi}

Naskah Mawa'iz al-Badi' salah satu karya Abdurrauf yang memadukan paham tasawuf dengan syariah. Muatan di dalam naskah lebih banyak pada introspeksi diri (penghayatan) dan nasihat-nasihat yang sangat penting bagi pribadi setiap muslim bersifat spiritual (tasawuf). Isi kandungannya meliputi; ajaran mengenai Tuhan dan hubungan-Nya dengan ciptaan; tentang neraka dan surga; dan cara-cara yang baik untuk mendapatkan keridhaan Tuhan. Selain itu, kitab ini juga menyeimbangkan antara pengetahuan ('ilm) dan perbuatan baik ('amal). Pengajaran yang ada di dalam -sekurang-kurangnya- memiliki tiga tujuan utama, yaitu; membenci dan menjauhi segala dosa; menjaga kesucian jiwa dari segala sifat dan perilaku tercela; dan pendekatan diri kepada Allah.

\section{Keterangan}

Halaman akhir tidak ada, dan terdapat tiga halaman kosong, walaupun demikian terdapat alihan kata pada halaman kosong tersebut. 


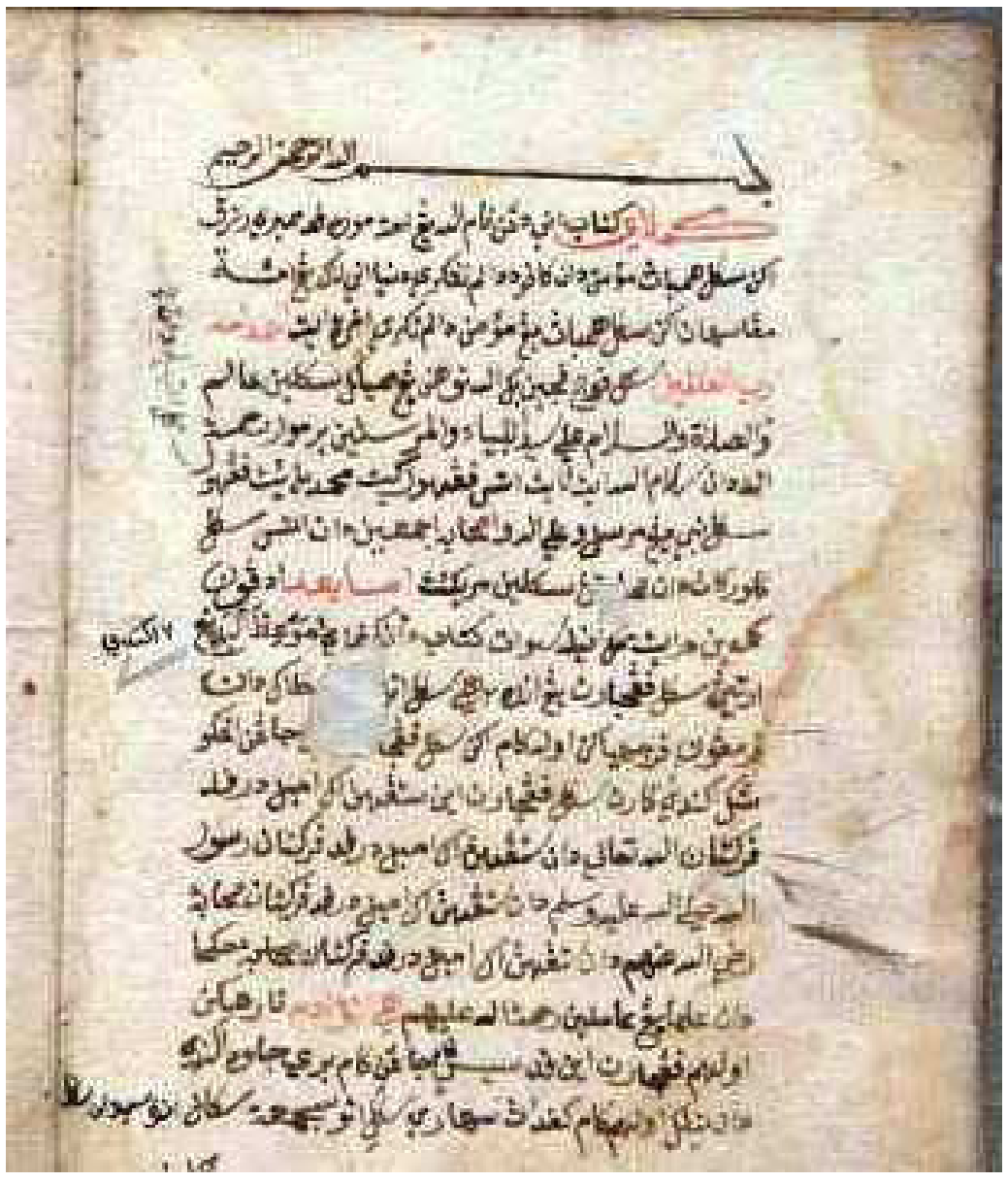

Halaman awal naskah Mawaizh al-Badi'ah 


\begin{tabular}{cccc}
\multicolumn{4}{c}{ Al-Mawaidh al-Badi'ah } \\
00/TS/TAM-55/2012 & Jawi & Prosa & $60 \mathrm{hlm}$ \\
Kertas Eropa & $23 \times 17 \mathrm{~cm}$ & $14 \times 8 \mathrm{~cm}$ & $19 \mathrm{baris} / \mathrm{hlm}$
\end{tabular}

\section{Pengarang}

Abdurrauf al-Jawi al-Fansuri

\section{Penulisan}

\section{Kolofon}

\section{Cap Kertas}

Bulan Sabit Bersusun Tiga (Venice, 1725)

\section{Gambaran Isi}

Naskah Mawa'iz al-Badi' salah satu karya Abdurrauf yang memadukan paham tasawuf dengan syariah. Muatan di dalam naskah lebih banyak pada introspeksi diri (penghayatan) dan nasihat-nasihat yang sangat penting bagi pribadi setiap muslim bersifat spiritual (tasawuf). Isi kandungannya meliputi; ajaran mengenai Tuhan dan hubungan-Nya dengan ciptaan; tentang neraka dan surga; dan cara-cara yang baik untuk mendapatkan keridhaan Tuhan. Selain itu, kitab ini juga menyeimbangkan antara pengetahuan ('ilm) dan perbuatan baik ('amal). Pengajaran yang ada di dalam -sekurang-kurangnya- memiliki tiga tujuan utama, yaitu; membenci dan menjauhi segala dosa; menjaga kesucian jiwa dari segala sifat dan perilaku tercela; dan pendekatan diri kepada Allah. 


\section{Keterangan}

Naskah ini milik Teungku Ainal Mardhiyah di Meunasah Keutapang, Teupin Raya, Pidie. Kondisi naskah masih tergolong baik, dapat terbaca. Setiap halaman terdapat alihan kata, tidak ada penomoran baik latin maupun arab. Teks ditulis dengan tinta hitam dan rubrikasi berwarna merah. Halaman akhir naskah telah hilang, sehingga tidak diketahui kolofon dan identitas naskah. 


\section{Nazam Aceh}

00/TS/MNA-.601

Aceh

Prosa

$16 \mathrm{hlm}$

Kertas Eropa

$22 \times 16 \mathrm{~cm}$

$18,5 \times 13,5 \mathrm{~cm}$

25 baris/hlm

\section{Pengarang}

\section{Penulisan}

\section{Kolofon}

\section{Cap Kertas}

\section{Gambaran Isi}

Naskah ini merupakan teks berbahasa Aceh yang mengkaji tentang sifat wajib dan mustahil bagi Allah, teks ini menguraikan satu persatu dua puluh sifat wajib dan mustahil bagi Allah. Dalam nazam tersebut menguraikan tentang syariat, tarekat dan hakikat menurut Syeikh Najmuddin, bahwa syariat itu umpama bahtera, tarekat umpama laut dan hakikat umpama mutiara, semua ini tidak dapat dipisahkan satu persatu dan harus dipadukan.

\section{Keterangan}

Judul naskah Nazm Aceh disebutkan di kolofon teks naskah tersebut. Naskah ini memiliki beberapa teks, isinya tentang pembagian sifatsifat Allah, tatacara bersuci, sembahyang, dan ilmu tajwid.

Pada bagian akhir naskah ini terdapat doa-doa dan shalawat kepada nabi. 


\section{Kalimat Thayyibah}

$\begin{array}{cccc}\text { 00/TS/MNA-847 } & \text { Aceh } & \text { Puisi } & 30 \mathrm{hlm} \\ \text { Kertas Eropa } & 22.5 \times 15.5 \mathrm{~cm} & 18.5 \times 11 \mathrm{~cm} & 22 \mathrm{baris} / \mathrm{hlm}\end{array}$

\section{Pengarang}

\section{Penulisan}

\section{Kolofon}

\section{Cap Kertas}

Bulan Sabit Bersusun Tiga

\section{Gambaran Isi}

Naskah ini ditulis dalam bentuk puisi dalam bahasa Aceh, setiap awal pembahasan akan dimulai dengan kalimat "La ilaha illa Allah Kalimat Tayyibah Bekal Mati". Bagian awal syair ini menceritakan keengganan iblis sujud kepada Nabi Adam, akibatnya dia dikeluarkan dari surga, dan akhirnya ia bersumpah akan menggoda seluruh manusia nanti hingga hari kiamat. Selanjutnya, teks menguraikan keutamaan kalimat zikir La ilaha illa Allah, faedah, makna kalimat tersebut dan keesaan Allah, yang dapat diamalkan oleh seseorang suluk atau pun pengikut tarekat tertentu.

\section{Keterangan}

Judul naskah disebut pada akhir syairnya "Loen boeh nama Kalimat Tayyibah, soe yang baca sah leumah hate [Kuberi nama Kalimat Tayyibah, siapa yang baca akan terbuka hatinya]". 


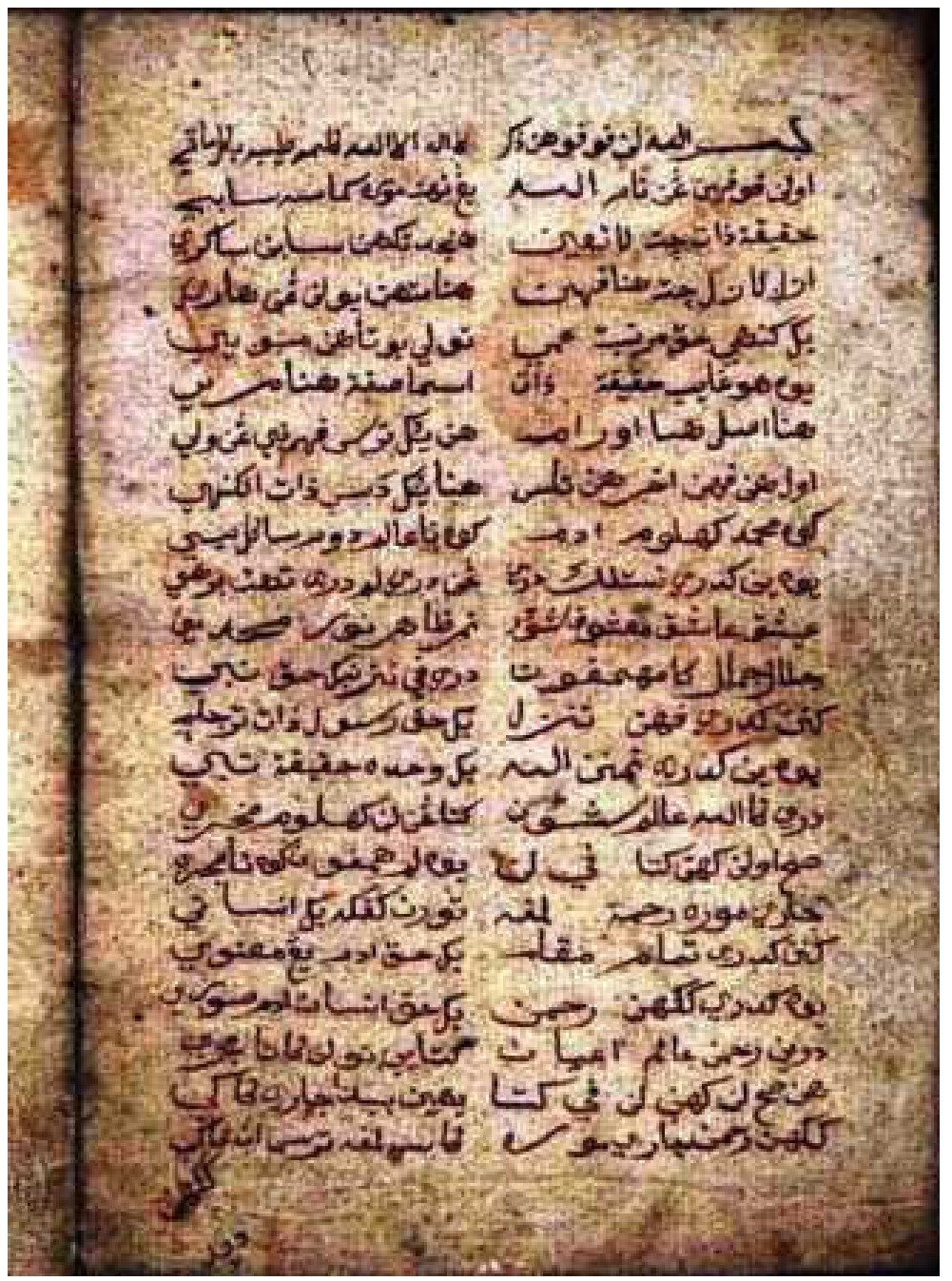

Halaman awal Kalimat Tayyibah 


\section{Shifat 'Isyrun}

00/TS/MNA-.830

$$
\text { Aceh }
$$

Prosa

$32 \mathrm{hlm}$

Kertas Eropa

$17 \times 10.5 \mathrm{~cm}$

$11.5 \times 7 \mathrm{~cm}$

13 baris/hlm

\section{Pengarang}

\section{Penulisan}

\section{Kolofon}

\section{Cap Kertas}

\section{Gambaran Isi}

Teks naskah menjelaskan sifat-sifat Allah 20 dengan dalil-dalil dari Al-Qur'an; uraian tentang zat Tuhan, Wujudiyah; beberapa hadis Nabi yang dilengkapi dengan arti dan penjelasannya.

\section{Keterangan}

Kondisi naskah baik dan terbaca, jika dilihat kondisi tersebut naskah pernah terendam atau terkena air, sehingga meninggalkan bekas di lembaran kertas. 
Bab 2: Koleksi \& Katalogisasi: Naskah Tasawuf di Propinsi Aceh

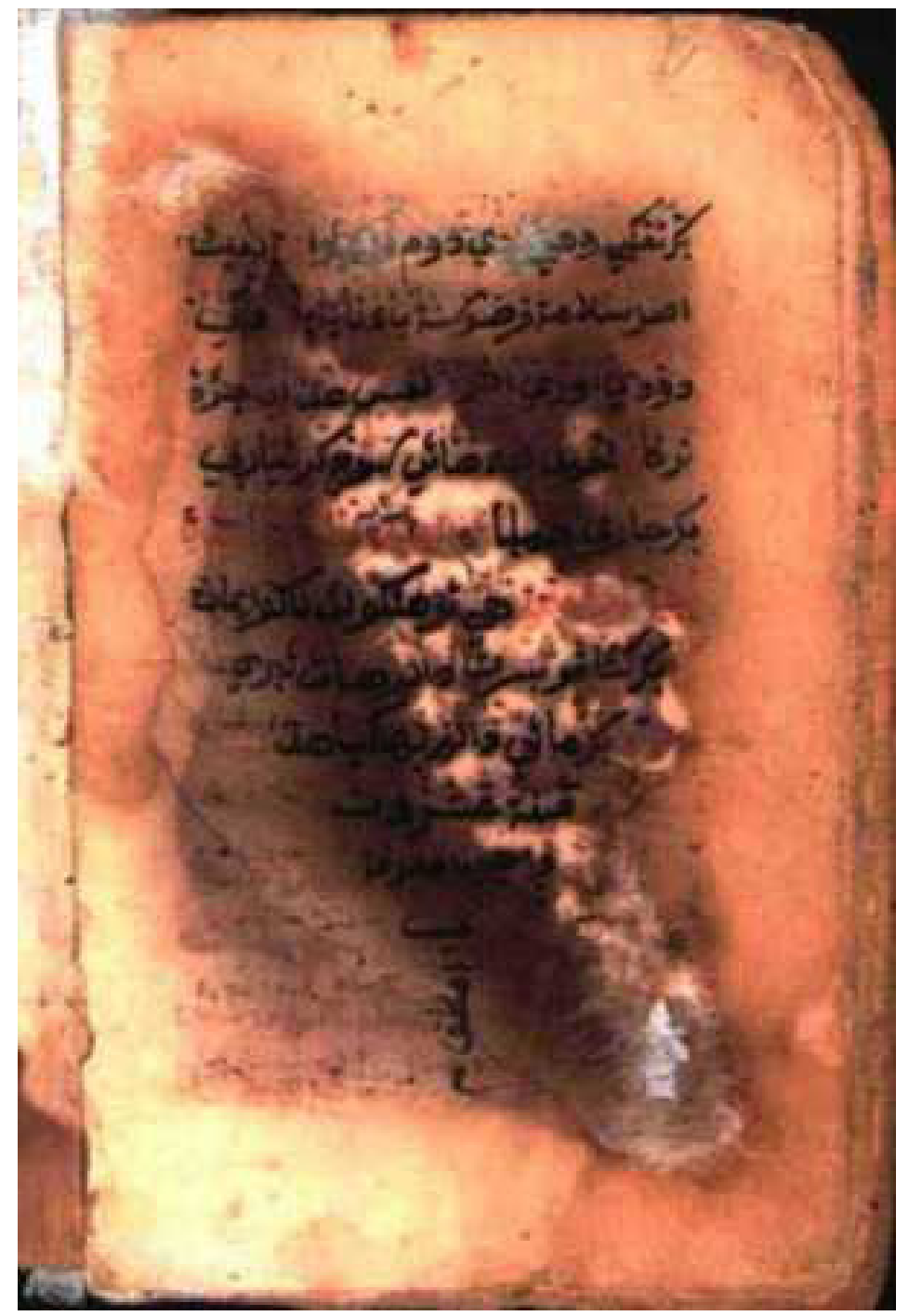

Kolofon Naskah Sifat 'Isyrun 


\section{Al-Nuskhah al-Mubarakah}

00/TS/MNA-.762

Arab

Prosa

$88 \mathrm{hlm}$

Kertas Eropa

$22 \times 15.5 \mathrm{~cm}$

$14 \times 9 \mathrm{~cm}$

19 baris/hlm

\section{Pengarang}

Leube Abdullah Lam Bada, dari teks asli Leube Polem Klieng Ibn Imam Pameurubok.

\section{Penulisan}

Hari Selasa, 15 Sya'ban 1205 H [19 April 1791 M], waktu Asar, di tengah laut Hindia dalam perjalanan.

\section{Kolofon}

Tammat al-Nuskhah al-Mubarakahfi wasth bahri al-hindi 'inda almarkab al-ba'in, waqt al-'ashr yaum al-tsulasa', wakana hijrat al-Nabi shallallahu 'alaihi wasallam khamsah wa-mi'atani ba'da al-alfi $f$ syahr sya'ban khamsat 'asyara yauman.

\section{Cap Kertas}

Birds, Cayam Jantan, tahun $1788 \mathrm{M}$

\section{Gambaran Isi}

Teks naskah ini dalam bahasa Arab yang membahas tentang hukum akal, sifat wajib, mustahil, dan jaiz bagi Allah dan rasul dengan dalildalil dari Al-Qur'an dan hadis Nabi.

\section{Keterangan}

Teks al-Nuskhah al-Mubarakah memiliki kesamaan isi dengan teks naskah al-Syarh al-Mubarak di permulaan teks, pertengahan, dan penutupannya. Hanya penjelasan yang ada di dalam naskah ini ada beberapa perbedaan. Dalam al-Nuskhah al-Mubarakah banyak terdapat kertas tambahan dan kosong yang diselipkan untuk menjelaskan matan teks. 


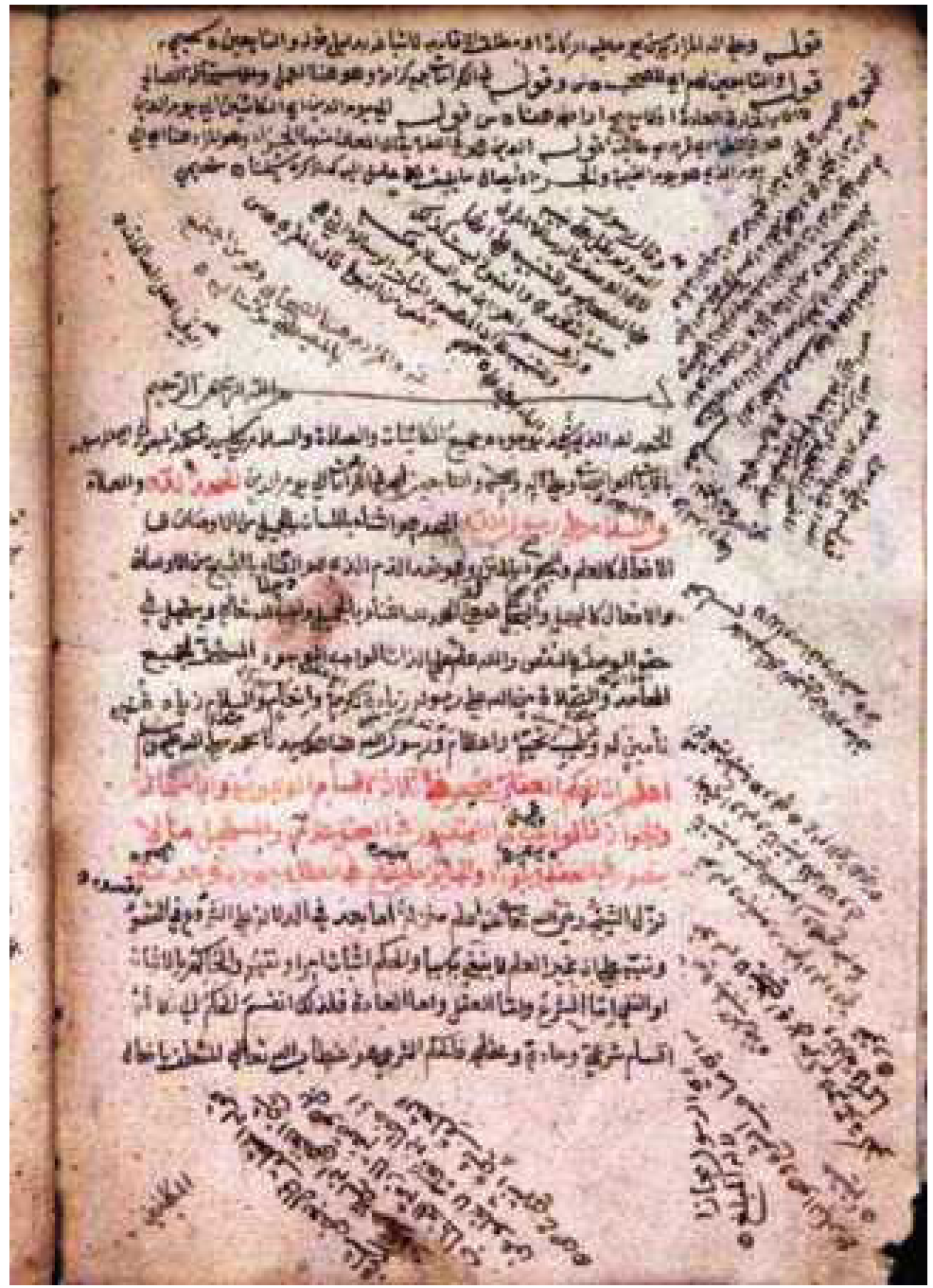

Halaman awal naskah al-Nuskhah al-Mubarakah 


\section{Sullam al-Mustafidin}

$\begin{array}{cccc}\text { 00/TS/MNA-/SZ/ } & \text { Jawi } & \text { Prosa } & 101 \mathrm{hlm} \\ \text { Kertas Eropa } & 21 \times 15 \mathrm{~cm} & 15.5 \times 10 \mathrm{~cm} & 19 \text { baris } / \mathrm{hlm}\end{array}$

\section{Pengarang}

Abdurrauf al-Jawi al-Fansuri

\section{Penulisan}

\section{Kolofon}

\section{Cap Kertas}

Fleur-De-Lis (Lisbon, 1751)

\section{Gambaran Isi}

Naskah ini membahas tentang kewajiban seorang muslim yang sudah baligh dan mukallaf kepada Allah. Naskah ini terdiri dari 14 pasal; ketauhidan; sifat wajib bagi Allah; mustahil; dan jaiz bagiNya; Asma Allah yang terdiri dari asma' zat, asma' sifat asma' af'al. Pemikiran ini merujuk kepada kitab Insya' al-Dawa'ir karangan Muhyiddin Ibn 'Arabi. Pasal keenam; wajib, jaiz, dan mustahil bagi Rasulullah; iradah dan qudrah; hukum akal; hal-hal yang ghaib; alam kubur; surga dan neraka; mauqif (posisi) mukmin di akhirat, yaitu seorang mukmin akan dapat melihat wajh Allah di surga nantinya; dan dua pasal terakhir adalah hisab; dan orang-orang yang menyangkal agama.

\section{Keterangan}

Dalam teks ini tidak ada nama pengarang. Akan tetapi, dari beberapa naskah yang lain diyakini bahwa teks ini adalah karya Syeikh Abdurrauf bin Ali al-Jawi al-Fansuri. Tulisan teks berwarna hitam dan rubrikasi merah. Naskah dijilid dengan karton tebal dan kain songket berwarna merah dan benang emas. Kondisi naskah 
kurang baik, terutama di halaman awal yang berlobang karena bakteri/serangga. Ada ilustrasi lingkaran di halaman 62 berbentuk lingkaran, akan tetapi belum diisi tulisan teks. Kolofon naskah terdapat keterangan silsilah Nabi Muhammad sampai kepada Nabi Adam yang tulis berlainan arah dari matan teks naskah.

Hampir setiap halaman bagian depan dan belakang terdapat catatan-catatan pinggir dengan posisi tidak beraturan, yang secara keseluruhan merupakan penjelasan atas beberapa bagian pada teks utama (matan).

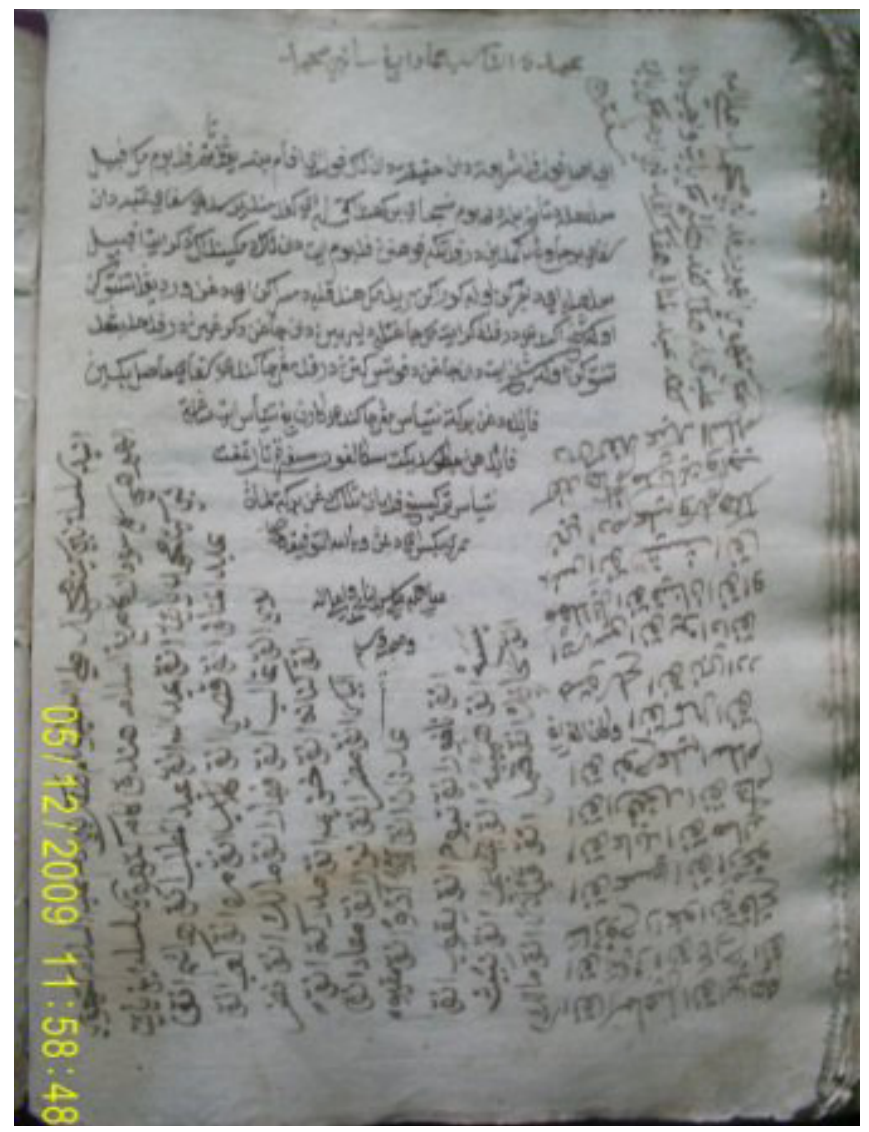

Kolofon naskah Sullam al-Mustafidin 


\section{Al-Haqiqah al-Muhammadiyah}

00/TS/MNA-.1671

Jawi

Kertas Eropa

$20.5 \times 15 \mathrm{~cm}$
Prosa

$13 \times 11 \mathrm{~cm}$
$19 \mathrm{hlm}$

19 baris/hlm

\section{Pengarang}

\section{Penulisan}

\section{Kolofon}

\section{Cap Kertas}

Pro Patria (Tahun tidak diketahui)

\section{Gambaran Isi}

Naskah ini membahas tasawuf tingkat tinggi, dimulai tentang kejadian nur Nabi Muhammad, disebutkan "Dan adalah pengetahuannya akan Dia atas jalan ljmal itu martabat wahdat-nya, maka wahdat itulah haqiqat Muhammdiyah, wa-ilmuha mufashilah". Uraian dari wahdaniyyah adalah al-haqiqah al-insaniyyah, dan ia dikategorikan dalam martabat wahidiyah.

Kemudian, naskah menjelaskan beberapa istilah dan ungkapan makna yang sering digunakan oleh kaum sufi, merujuk kepada pendapat Syeikh Muhyiddin Ibn 'Arabi, seperti istilah ahadiyah, wahdah, wahidiyyah, a'yan tsabitah, a'yan kharijiyyah, tasybih, tanzih, dan lainnya.

Kajian dalam naskah ini juga dilengkapi dengan dalil-dalil ayat Al-Qur'an dan hadis Nabi, bagian ini disebutnya "Faedah pada menyatakan segala dalil yang mencukupkan kepada alim a ini", dan selanjutnya tanya jawab.

\section{Keterangan}

Naskah ini disalin berbeda jumlah baris teks di beberapa halaman, terkadang ada 19 baris, 18 baris dan 17 baris, dan di beberapa 
halaman terdapat catatan-catatan koreksian dan penjelasan dari matan teks (teks utama). Naskah ini tidak lengkap halaman akhir.

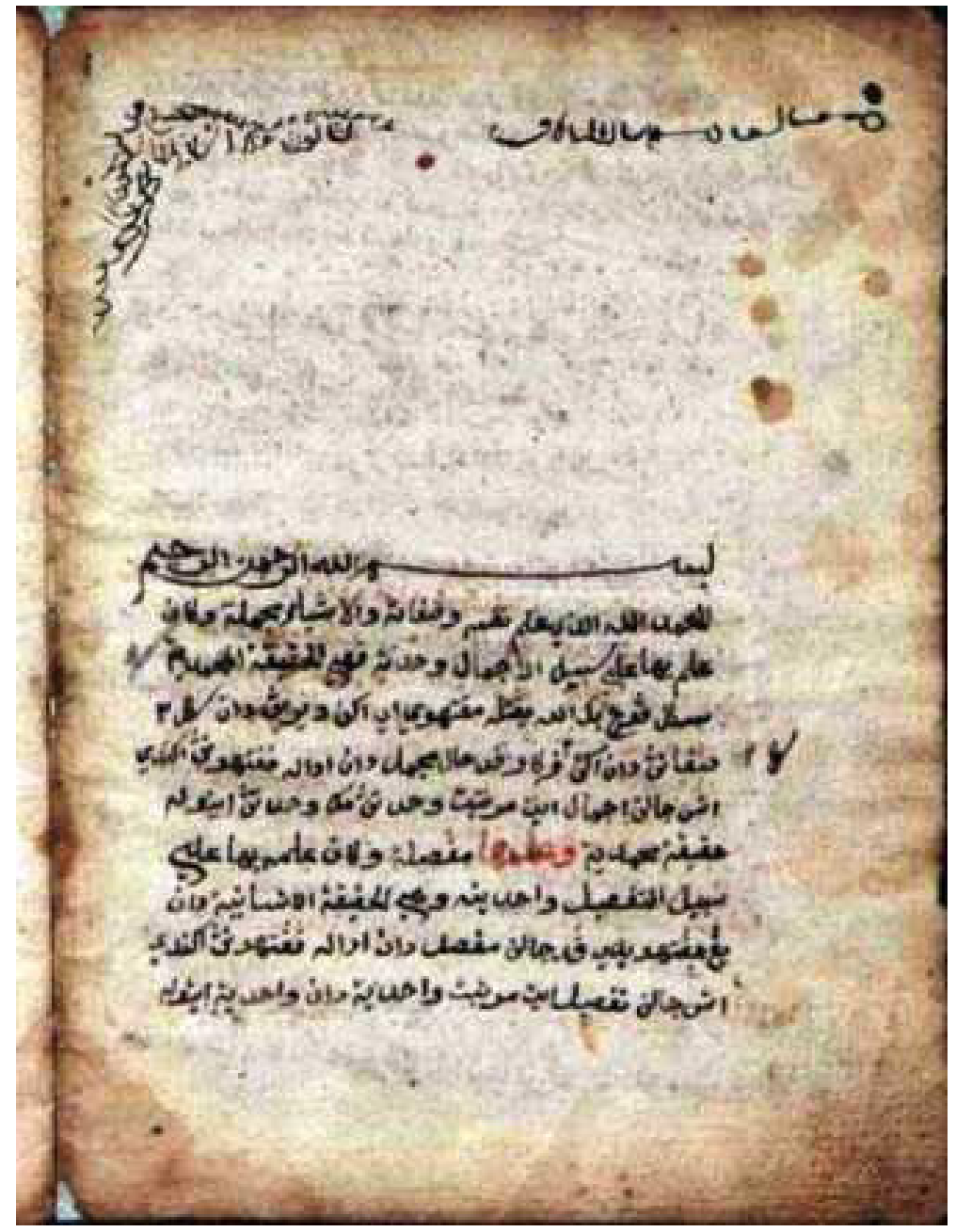

Halaman awalal-Haqiqah al-Muhammadiyah 


\begin{tabular}{cccc}
\multicolumn{4}{c}{ [Waraqah Kejadian Insan] } \\
00/TS/MNA-.1338/a/ & Jawi & Prosa & $18 \mathrm{hlm}$ \\
Kertas Eropa & $22.5 \times 16 \mathrm{~cm}$ & $17 \times 10 \mathrm{~cm}$ & $19 \mathrm{baris} / \mathrm{hlm}$
\end{tabular}

\section{Pengarang}

\section{Penulisan}

\section{Kolofon}

\section{Cap Kertas}

Bulan Sabit Tersenyum Dalam Perisai, 1829 M

\section{Gambaran Isi}

Naskah ini berbahasa Melayu yang menjelaskan tentang kejadian asal mula seluruh manusia dan sebab musabab dijadikan alam ini, nur Muhammad, pembagian martabat manusia dan lain-lain.

\section{Keterangan}

Judul di atas disesuaikan dengan oxordium naskah yang menyebutkan waraqah asal mula kejadian insan. Naskah ini koleksi Museum Negeri Aceh, sesuai kandungannya naskah ini lengkap dan kondisi fisik naskah juga terpelihara, teksnya terbaca. Setiap halaman memiliki alihan kata, ditulis dengan khat naskhi, warna teks hitam, kecuali rubrikasi menggunakan tinta berwarna merah. 


\section{Perintah Makrifat Syahadat}

$\begin{array}{cccc}\text { 00/TS/MNA-512/b/ } & \text { Jawi } & \text { Prosa } & 62 \mathrm{hlm} \\ \text { Kertas Eropa } & 20.5 \times 15.5 \mathrm{~cm} & 13.5 \times 9.5 \mathrm{~cm} & 19 \mathrm{baris} / \mathrm{hlm}\end{array}$

\section{Pengarang}

\section{Penulisan}

Ahad, Rabiul Akhir, 1221 H, waktu Dhuha

\section{Kolofon}

Dan selesailah hamba faqir ila Allah Ta'ala yang sehina-hina daripada segala makhluk menterjemahkan kitab ini pada Hijrah Nabi Shallallahu 'Alaihi Wasallam seribu dua ratus dua puluh setahun pada hari-hari bulan Rabi'ul-Akhir pada hari Ahad pada waktu Dhuha. Tammat, amin-amin.

\section{Cap Kertas}

Lion (singa) (1745 M)

\section{Gambaran Isi}

Naskah ini mengulas tentang ilmu ma'rifat, syahadat, hakikat, dan syariat yang dalam bentuk tanya jawab. Dimulai dari halaman pertama: "bab ini pada menyatakan perintah makrifat syahadat asyhadu an la ilaha illa Allah, wa-asyhadu anna Muhammad rasulullah, bermula asyhadu itu jalan apa, an la itu jalan apa, ilaha itu jalan apa, illa Allah itu jalan apa?. Jawab; asyhadu itu jalan syariat, an la itu jalan tarekat, ilah itu jalan hakikat, illa Allah itu jalan makrifat". Selanjutnya, pembahasan dalam naskah dikemukakan dalam bentuk pengajaran (peringatan), dari pelajaran pertama hingga ke lima puluh. Di bagian akhir disebutkan beberapa nasihat dan petunjuk. 


\section{Keterangan}

Teks naskah ditulis dalam bentuk khat naskhi, berwarna hitam dan rubrikasi merah, ukuran tulisannya lebih kecil. Terdapat dua halaman kosong di tengah naskah ini, sehingga teks tidak tersalin tentang pelajaran yang pertama dan yang kedua. Sepertinya penyalin naskah sengaja meninggalkannya karena dimungkinkan tidak lengkap dari naskah sebelumnya.

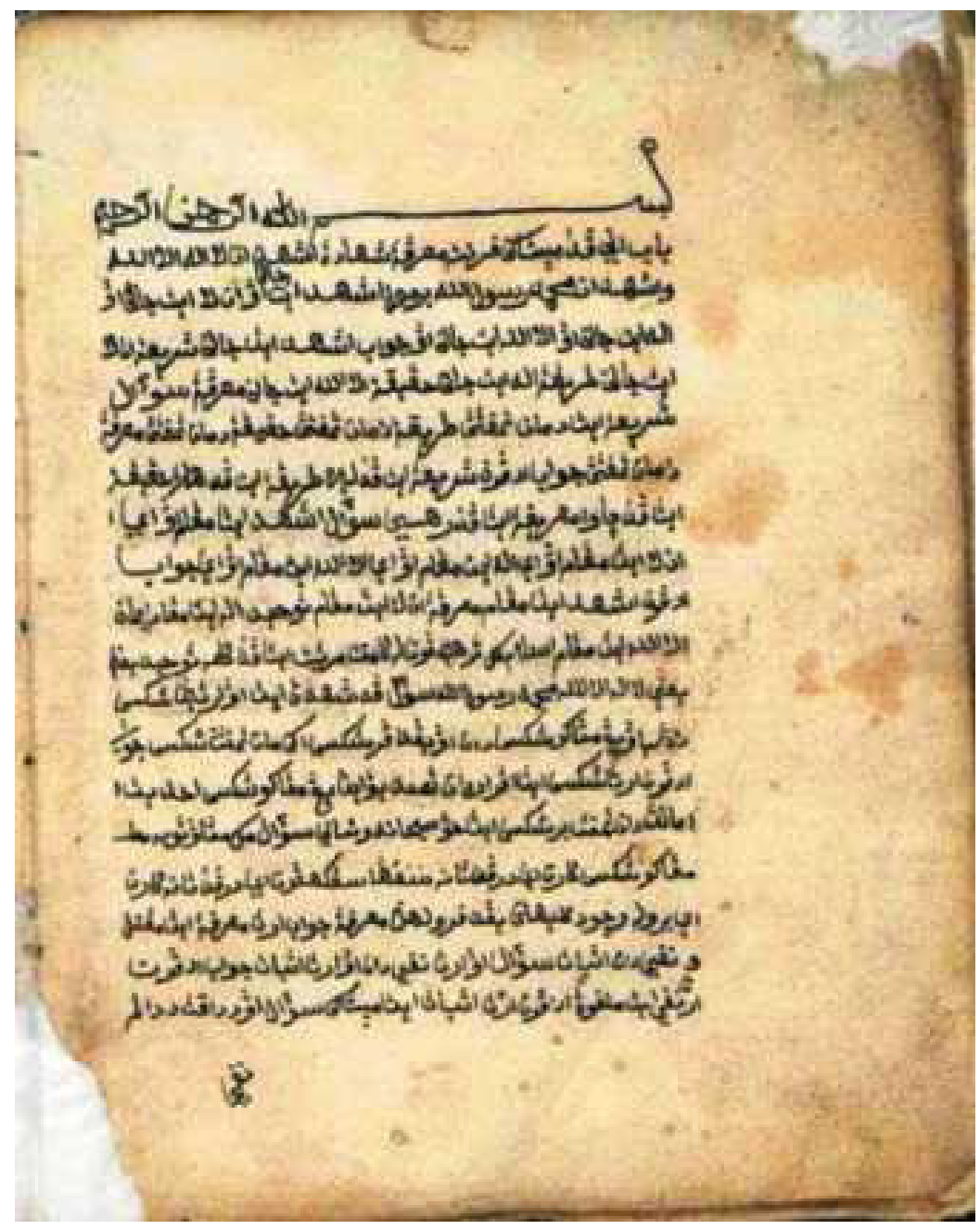

Halaman awal naskah Perintah Makrifat Syahadat 


\section{Sya'ir Makrifat}

00/TS/MNA-1435/c/

$\begin{array}{ccc}\text { Jawi } & \text { Prosa } & 15 \mathrm{hlm} \\ 22 \times 16 \mathrm{~cm} & 14.5 \times 9.5 \mathrm{~cm} & 19 \text { baris } / \mathrm{hlm}\end{array}$

\section{Pengarang}

\section{Penulisan}

\section{Kolofon}

Tammat al-kalam Sya'ir Makrifah, beu that galak oleh kita-kita. Amin.

\section{Cap Kertas}

Bulan Sabit Bersusun Tiga, tahun 1823-1824 M

\section{Gambaran Isi}

Naskah ini membahas tentang Nur Muhammad dan Sirrullah yang diistilahkan kepada beberapa persamaan, seperti wujud ilm, wujud idhafi, wujud mutlak amanat Allah, zat Allah, sifat Allah, af'al Allah, asma' Allah, ruh idhafi, rahman, rahim, khaliq, a'yan tsabitah.

Pembahasan tasawuf dalam bentuk tanya jawab yang membahas tentang istilah-istilah yang berhubungan dengan tasawuf, syahadat, ketuhanan, asal manusia, asal alam, dan lainnya.

\section{Keterangan}

Naskah ini terdiri dari beberapa teks yang membahas masalah tasawuf dan sufisme. Teks ini terjemahan dan penjelasa (syarah) dari karya. Dalam beberapa pendapat menyebut "kata Syeikh" merujuk kepada perkataan Mahyuddin ibn ‘Arabi.

Pada akhir kalimat teks naskah ini ditemukan beberapa kata berbahasa Aceh yang bercampur dengan bahasa Jawi. 


\section{Al-Ma'rifat al-Haqq al-Mubin}

No. 07.1435/d/

$$
\text { Jawi }
$$

Prosa

$24 \mathrm{hlm}$

Kertas Eropa

$22 \times 16 \mathrm{~cm}$

$14.5 \times 9.5 \mathrm{~cm}$

19 baris/hlm

\section{Pengarang}

'Aidarush (?)

\section{Penulisan}

\section{Kolofon}

Tammat pakaian segala ahlu Allah yang Majid lagi Kamil, washahibuhu Mukamil. Intaha al-kalam al-kutub al-'arifin, ya rabb al'alamin. Amin.

\section{Cap Kertas}

Bulan Sabit Bersusun Tiga, tahun 1823-1824 M

\section{Gambaran Isi}

Sesuai isi naskah, kitab ini ditulis sesuai sanad dari Syeikhnya, penulis menyebut silsilah Syeikh-Syeikhnya hingga pada Sayyid 'Aidarush Abu Sa'id. Pembukaan masalah tentang darah yang berasal dari urat besar, hingga berasal dari cahaya, dan cahaya itu berasal dari Azali. Azali tiada kesudahan dan tiada terhingga. Selanjutnya, pembahasannya dalam bentuk tanya jawab tentang makrifat, nur Allah, ism, angin, wahdatul wujud, ruh, asma', dan sifat.

\section{Keterangan}

Teks naskah ini tergabung dengan beberapa naskah lainnya. Teks ditulis dengan rapi dan jelas dengan khat naskhi, teks berwarna hitam dan rubrikasi merah. 


\section{Perintah Zikir La Ilaha IIla Allah}

$\begin{array}{cccc}\text { 00/TS/MNA-1435/e/ } & \text { Jawi } & \text { Prosa } & 11 \mathrm{hlm} \\ \text { Kertas Eropa } & 22 \times 16 \mathrm{~cm} & 14.5 \times 9.5 \mathrm{~cm} & 19 \mathrm{baris} / \mathrm{hlm}\end{array}$

\section{Pengarang}

Mas'ud

\section{Penulisan}

\section{Kolofon}

Tammat al-kitab perintah zikir la ilaha illa Allah dengan berkat Nabi Sayyid al-Mursalin. Amin. Inilah yang empunya risalah ini hadzihi shahib Mas'ud pada waktu Dzuhur pada tempat Diawee.

\section{Cap Kertas}

Bulan Sabit Bersusun Tiga, tahun 1823-1824 M

\section{Gambaran Isi}

Naskah in termasuk kajian tasawuf tingkat tinggi, teks ini termasuk dalam tasawuf falsafi dan amali, karena selain tata cara-cara berzikir, juga disebutkan beberapa konsep sufi. Termasuk kalimat-kalimat syatahiyyat dalam dunia tasawuf, seperti perkataan para filusuf "Subhana ma a'zhama sya'ni", "Kuntu kanzan makhfiyyan" dan juga "man 'arafa nafsahu faqad 'arafa rabbahu".

\section{Keterangan}

Teks naskah ini tergabung dengan beberapa naskah lainnya. Teks ditulis dengan rapi dan jelas dengan khat naskhi, teks berwarna hitam dan rubrikasi merah. 


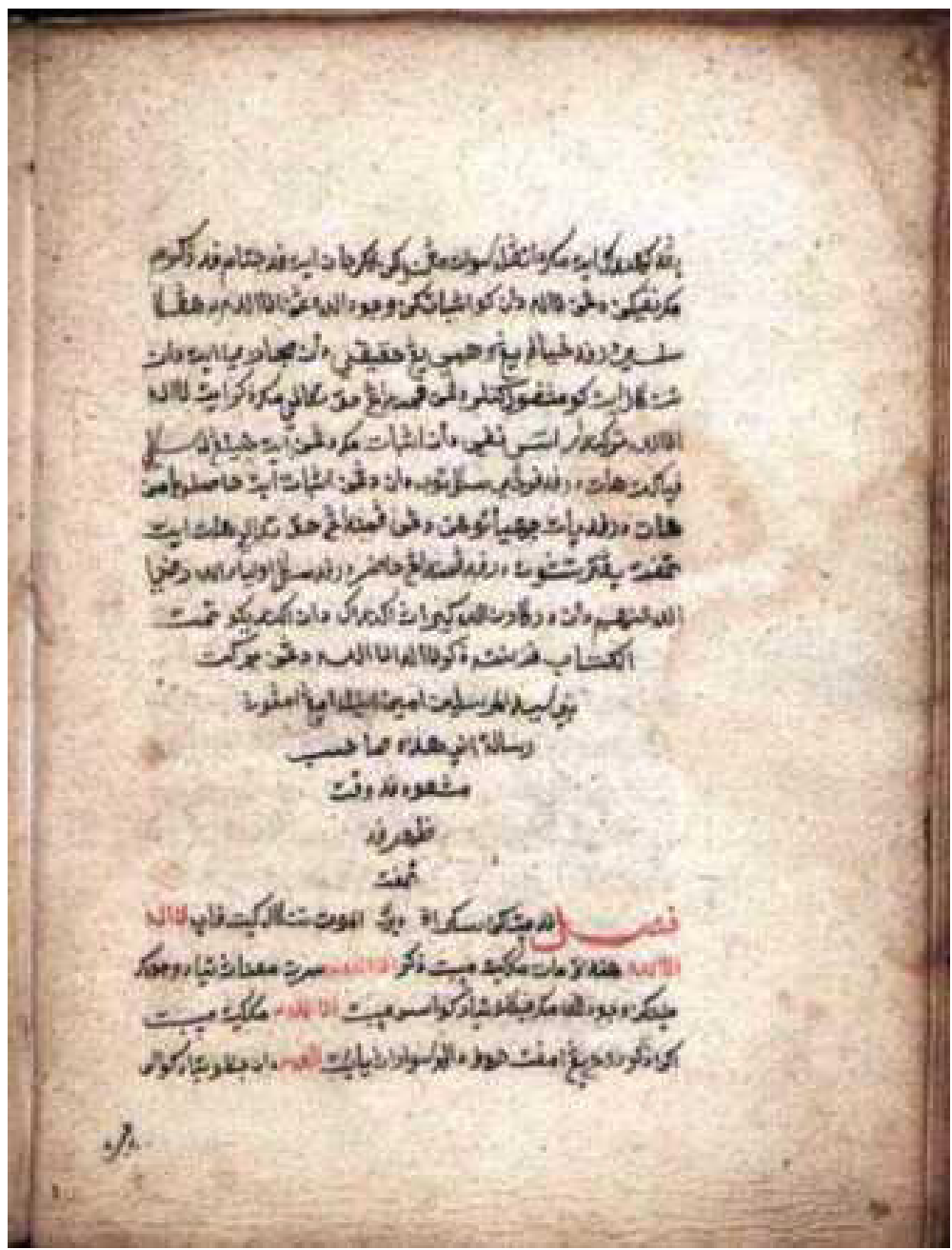

Kolofon Naskah Perintah Zikir La ilaha illa Allah 


\section{[IImu Syair Tasawuf]}

$\begin{array}{cccc}\text { 00/TS/MNA-1663 } & \text { Arab \& Jawi } & \text { Prosa } & 29 \mathrm{hlm} \\ \text { Kertas Eropa } & 21.5 \times 16.5 \mathrm{~cm} & 13.5 \times 8 \mathrm{~cm} & 11 \mathrm{baris} / \mathrm{hlm}\end{array}$

\section{Pengarang}

\section{Penulisan}

\section{Kolofon}

\section{Cap Kertas}

\section{Gambaran Isi}

Naskah ini berisi doa dalam bentuk syair (bait) berbahasa Arab, kemudian diterjemahkan ke dalam bahasa Jawi, dan selanjutnya dijelaskan maksud dari bait-bait tersebut.

Cara berselawat kepada Nabi.

\section{Keterangan}

Ada lima halaman depan naskah menyebutkan tentang .... yang berbeda dengan kandungan utama naskah ini. Kemudian, di halaman akhir naskah ini terdapat 5 halaman kosong. 


\section{Manjah al-Anam fi Tabwib al-Hikam \\ 00/TS/MNA-.1364 \\ Jawi \\ Prosa \\ $46 \mathrm{hlm}$ \\ Kertas Eropa \\ $21.5 \times 17 \mathrm{~cm}$ \\ $15.5 \times 10.5 \mathrm{~cm}$ \\ 17 baris/hlm}

\section{Pengarang}

\section{Penulisan}

\section{Kolofon}

\section{Cap Kertas}

Bee Hive (tidak diketahui tahunnya)

\section{Gambaran Isi}

Kandungan naskah ini membahas secara filosofis dalam beberapa bagian penting dan bermanfaatnya. la dibagi perbab, bab pertama membahas tentang ilmu dan manfaatnya. Bab kedua tentang keikhlasan dalam beramal. Bab selanjutnya, hikmah shalat. Bab selanjutnya tentang uzlah dan khumul. Kemudian bab memelihara (ri'ayah) waktu, bab zikir, bab berkecukupan dan berhajat, bab riyazhah (melatih) jiwa dan menjauhi segala godaan, bab adab berdoa, bab menyerahkan diri kepada Allah, bab sabar terhadap bala dan cobaan, bab berzikir secara lembut dan mengikuti sunnah dalam beribadah.

Naskah ini banyak merujuk pendapat kepada Zaruq (Zarwaq).

\section{Keterangan}

Naskah ini tidak ada halaman bagian akhir. Beberapa halaman terdapat catatan-catatan kecil untuk menjelaskan syarah dari matan teks. Teks naskah ditulis dengan tinta hitam, sedangkan rubrikasi dan matannya berbahasa Arab ditulis dengan tinta merah, seluruhnya berjenis khat naskhi. 
Bab 2: Koleksi \& Katalogisasi: Naskah Tasawuf di Propinsi Aceh

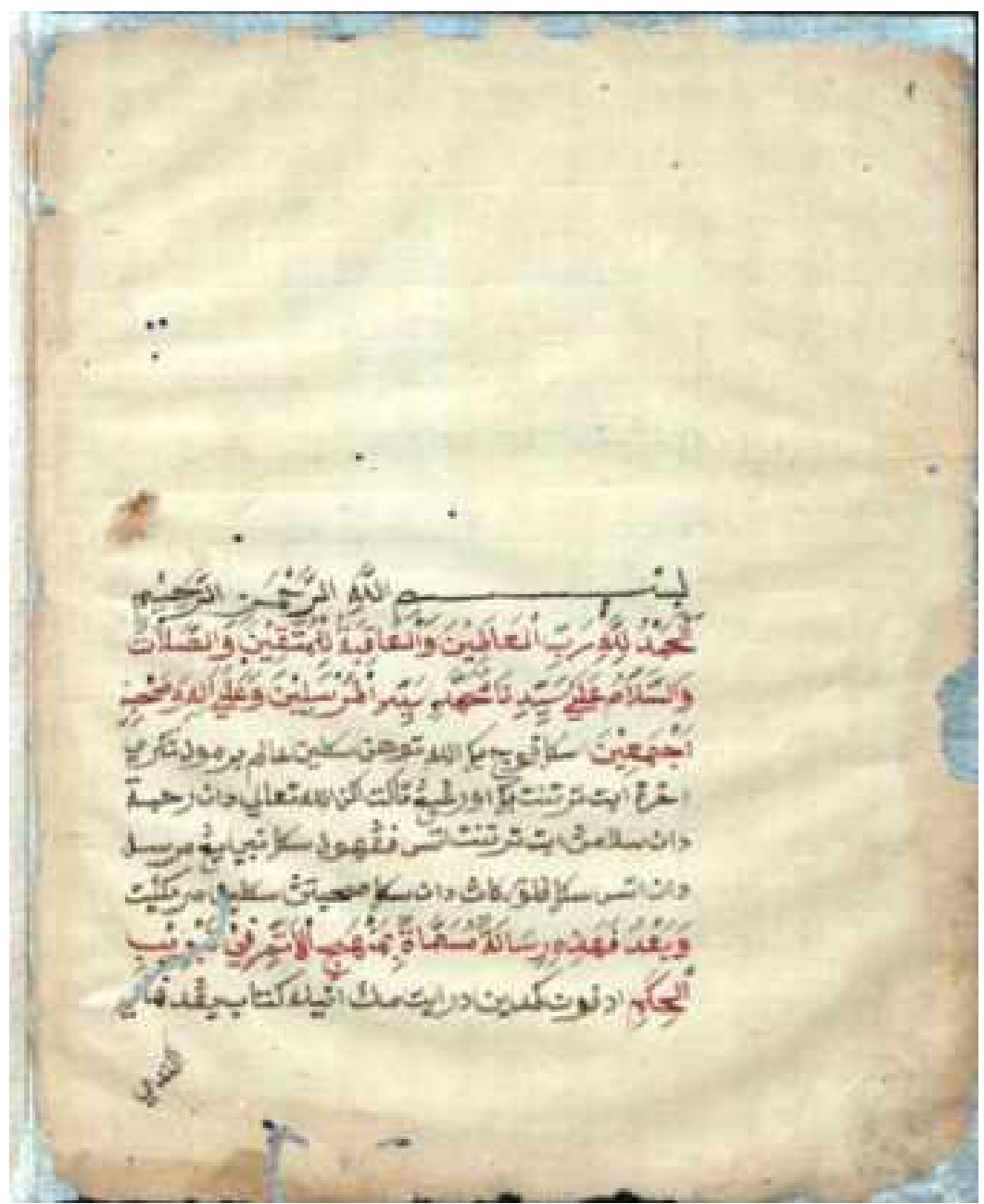

Halaman depan naskah Manhaj al-Anam fi Tabwib al-Hikam 


\section{Hadiyah al-Sabil}

$\begin{array}{cccc}\text { 00/TS/MNA-743/f/ } & \text { Jawi } & \text { Prosa } & 7 \mathrm{hlm} \\ \text { Kertas Eropa } & 17 \times 12 \mathrm{~cm} & 14 \times 8 \mathrm{~cm} & 9 \text { baris } / \mathrm{hlm}\end{array}$

\section{Pengarang}

Habib Hasan Haddadbin Habib ‘Abdullah Haddad

\section{Penulisan}

Muhammad Marhaban

\section{Kolofon}

Demikianlah tersebut dalam kitab Hadiyat al-Sabil karangan Habib Hasan Haddad anak Habib 'Abdullah Haddad. Wa-shallallah 'ala Sayyidina Muhammad wa-'alaalihi wa-shahbihi wasallam. Amin. Tammat.

\section{Cap Kertas}

Bulan Sabit Tersenyum dalam Perisai

\section{Gambaran Isi}

Naskah ini berisikan tentang cara-cara Shamadiyah (Thariqah Shamadiyah) yang diijazahkan oleh Habib Abdullah Haddad kepada muridnya. Maka diuraikan tata tertib membaca istighfar, doa, dan ayat-ayat Al-Qur'an beberapa surat Makkiyah.

Selanjutnya, menyebutkan nama-nama silsilah Tarekat Shammadiyah yang diterima oleh Muhammad Marhaban di Jeddah pada tahun 1255 H [1839/40 M] hingga kepada Nabi Muhammad SAW.

\section{Keterangan}

Teks naskah ini terjilid dengan beberapa judul naskah lainnya yang berbeda tema, seperti doa-doa dan sifat 20 bagi Allah. Teks ditulis dengan tinta hitam, dan rubrikasinya berwarna merah, jenis khat naskhi, dengan ukuran yang agak lebih besar. 


\begin{tabular}{cccc} 
& \multicolumn{3}{c}{ Hizb al-Bahr } \\
00/TS/MNA-743/b/ & Jawi & Prosa & $7 \mathrm{hlm}$ \\
Kertas Eropa & $17 \times 12 \mathrm{~cm}$ & $14 \times 8 \mathrm{~cm}$ & 9 baris/hlm
\end{tabular}

\section{Pengarang}

Syeikh Abu Hasan al-Syazili

\section{Penulisan}

Jum'at, Safar, $1291 \mathrm{H}[1874 / 75$ ]

\section{Kolofon}

Hadza khatm Hizb al-Bahr li-Syeikh Abi al-Hasan al-Syazili rahima Allah Ta'ala wa-nafa'ana bi-'ulumihi. Amin. Sanah 1291, Safar, Jum'at. Wa-Shallallahu 'ala sayyidina Muhammad wa-alihi wa-shahbihi wabaraka wasallam.

\section{Cap Kertas}

Bulan Sabit Tersenyum dalam Perisai

\section{Gambaran Isi}

Sesuai isi kandungan naskah, naskah ini berisikan bacaan doa dalam suatu tarekat, diawali niat doa kepada Nabi Muhammad, kemudian kepada seluruh mukmin, dan selanjutnya diniatkan kepada Syeikh Hasan al-Syazili.

Selanjutnya, membaca surat-surat Al-Qur'an, seperti surat alQadr, al-Qurasy, dan al-Ikhlas masing-masing sebanyak dua belas kali, dan surat al-Falaq dan al-Nas masing-masing sebanyak 3 kali, ditutup dengan surat al-Fatihah.

Selanjutnya, bacaan doa dan beberapa penggalan ayat-ayat AlQur'an yang dikhususkan dalam bacaan ini. 


\section{Keterangan}

Teks naskah ini terjilid dengan beberapa naskah lainnya dalam satu bundel. Seluruh teks ditulis dengan khat naskhi dan berwarna hitam, akan tetapi beberapa halaman naskah tampak luntur dan lembab, kemungkinan naskah ini pernah terendam air.

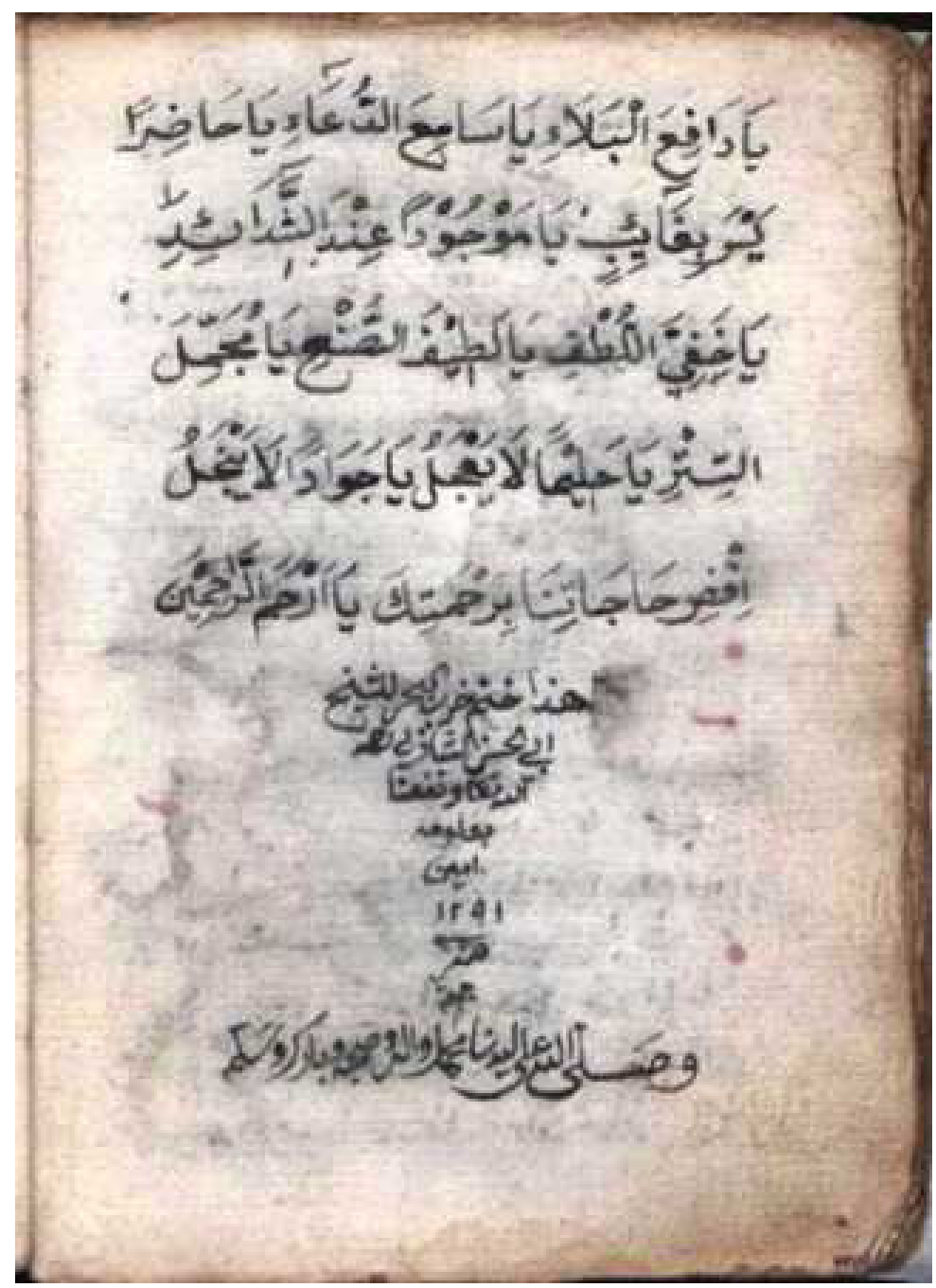

Kolofon naskah Hizb al-Bahr 


\section{Tibyan fi Ma'rifat al-Adyan}
00/TS/MNA-/SZ/
Kertas Eropa

$\begin{array}{cc}\text { Jawi } & \text { Prosa } \\ 15 \times 9,5 \mathrm{~cm} & 8 \times 7 \mathrm{~cm}\end{array}$

$93 \mathrm{hlm}$

19 baris/hlm

\section{Pengarang}

Nur al-Din bin 'Ali bin Hasanji Muhammad Hamid ar-Raniri

\section{Penulisan}

\section{Kolofon}

Wa-qad waqa'a al-faragh min taswid hadza al-kitab fi yawm sabt sabi'ah min shahr al-Muharram. Tamat hadza al-kitab ini ... [rusak] pada waktu Dhuha pada ... hari Sabtu Sab'ah dari bulan Muharram... [rusak sampai akhir bacaan].

\section{Cap Kertas}

Bulan Sabit tidak Sejajar Bersusun Tiga (Venice, 1785-1791)

\section{Gambaran Isi}

Sesuai dengan kandungan isinya, teks naskah ini terbagi pada dua bab; Pertama, perkembangan aliran kepercayaan dan agama non skriptural dan skriptural sebelum Islam hadir. Di dalamnya diuraikan golongan-golongan induk dalam kepercayaan pra Islam; Tabi'iyah (Taba'iyah); penyembah berhala (paganisme); Majusi; emanasi dan penyembah cahaya; Dahriyah (Mulahdifun) atau Mulhid, tidak bertuhan (atheis); dan Tanasukhiyah; yaitu sejenis reinkarnasi dan politheisme; dan terakhir, Ahl Kitab; yang terdiri dari Barahimah, Yahudi, dan Nasrani.

Bab kedua menjelaskan ikhtilaf segala mazhab (sekte/golongan) umat Nabi Muhammad SAW. Menurut hadis Rasulullah, bahwa aliran dalam Islam terbagi 72 sekte, keseluruhannya sesat dan menyesatkan kecuali satu golongan, yaitu Ahl Sunnah wal Jama'ah. Tujuh puluh dua kelompok sempalan muslim yang dianggap sesat 
dan menyesatkan berada di luar tradisi Sunni sejati, menurut Nuruddin al-Raniri berasal dari enam golongan utama, yaitu: Rafidhiyah, Kharijiyah, Jabariyah, Qadariyah, Jahmiyah Murji'ah. Selanjutnya, dijelaskan konsep-konsep tasawuf Ahl al-Haqq, yaitu Ahlullah yang berbeda dengan prinsip kaum Wujudiyah. Sebagaimana umumnya, karya Nuruddin al-Raniri adalah menangkal kesalahpahaman konsep tasawuf oleh pengikut Hamzah Fansuri dan Syamsuddin as-Sumatrani.

\section{Keterangan}

Naskah bersampul kain sulaman berwarna merah cerah dan dan garisan hiasan benang emas, terjilid rapi dan melekat kuat serta terikat dengan ikatan benang putih untuk menyatukan antar kuras. Kondisi naskah baik, selain tampak bekas terendam air di sekitar teks naskah, juga sudah banyak berlobang di tengah-tengah bacaan dari halaman pertama sampai halaman terakhir teks akibat dimakan rayap. Halaman pertama dan di kolofon terdapat ukiran bunga (iluminasi). 
Bab 2: Koleksi \& Katalogisasi: Naskah Tasawuf di Propinsi Aceh

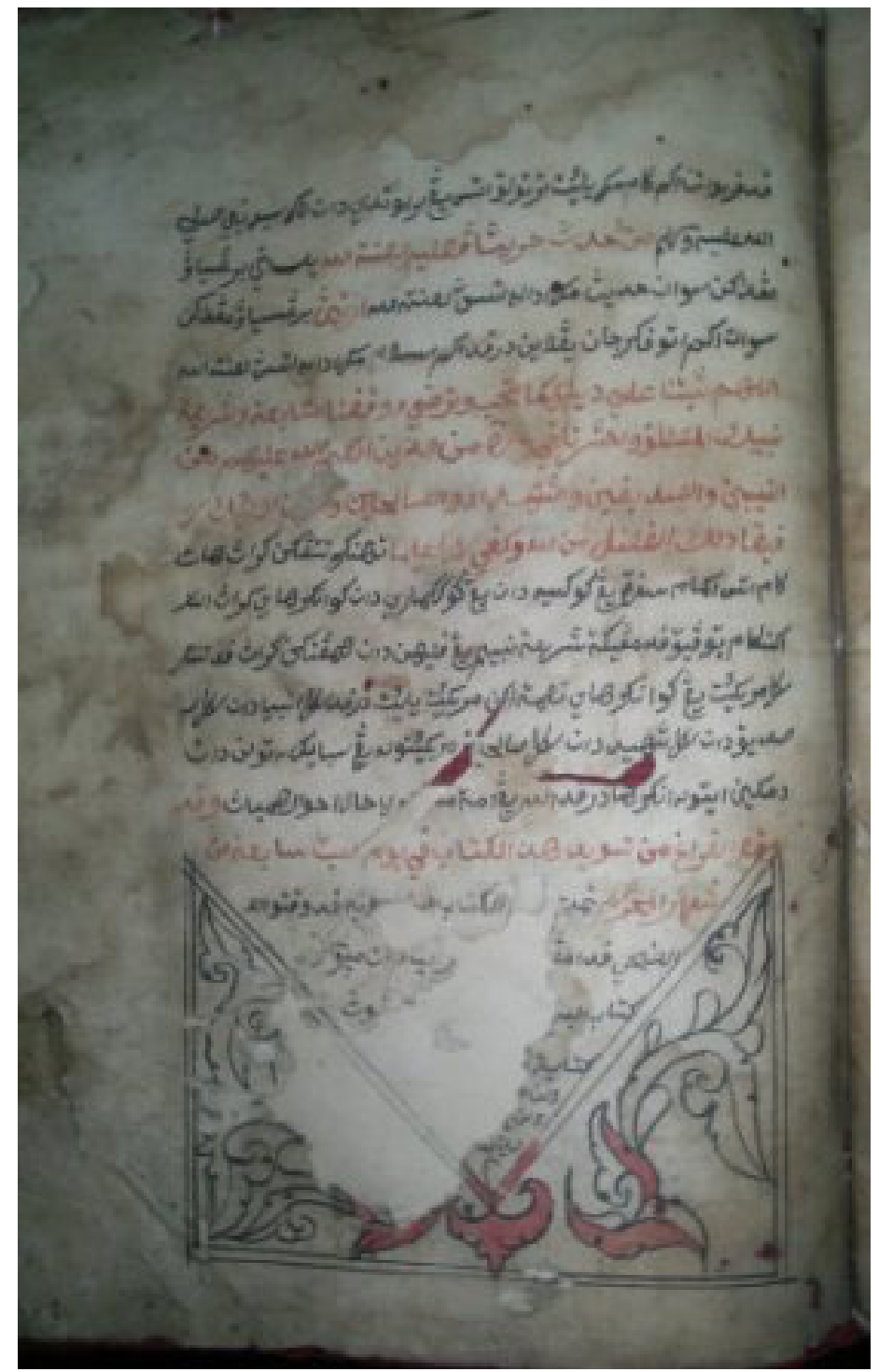

Kolofon Naskah Tibyan fi Ma'rifat al-Adyan 


\title{
Tibyan fi Ma'rifat al-Adyan
}

00/TS/MNA-1473

\author{
Jawi \\ $21,5 \times 16,5 \mathrm{~cm}$
}

Prosa

$112 \mathrm{hlm}$

Kertas Eropa

$15 \times 6 \mathrm{~cm}$

17 baris/hlm

\section{Pengarang}

Nur al-Din bin 'Ali bin Hasanji Muhammad Hamid ar-Raniri

\section{Penulisan}

Rabu, 8 Rabiul Akhir 1051 H [17 Juli 1641 M]

\section{Kolofon}

Qad waqa'a al-faragh min taswid hadza al-kitab fi yawm al-'arbi'a thamaniyah min shahr rabi' al-akhir fi sanah ihda wa-khamsina ba'da al-alf. Falaka al-hamd awwalan wa-akhiran wa-dzahiran wabathinan, wa-shalla Allah 'alayhi wa-'ala saiyyidina muhammad wa'alihi wa-shahbihi wasallam.

\section{Cap Kertas}

Bulan Sabit Sejajar Bersusun Tiga (Venice, 1725)

\section{Gambaran Isi}

Sesuai dengan kandungan isinya, teks naskah ini terbagi pada dua bab; Pertama, perkembangan aliran kepercayaan dan agama non skriptural dan skriptural sebelum Islam hadir. Di dalamnya diuraikan golongan-golongan induk dalam kepercayaan pra Islam; Tabi'iyah (Taba'iyah); penyembah berhala (paganisme); Majusi; emanasi dan penyembah cahaya; Dahriyah (Mulahdifun) atau Mulhid, tidak bertuhan (atheis); dan Tanasukhiyah; yaitu sejenis reinkarnasi dan politheisme; dan terakhir, Ahl Kitab; yang terdiri dari Barahimah, Yahudi, dan Nasrani.

Bab kedua menjelaskan ikhtilaf segala mazhab (sekte/golongan) umat Nabi Muhammad SAW. Menurut hadis Rasulullah, bahwa aliran dalam Islam terbagi 72 sekte, keseluruhannya sesat dan 
menyesatkan kecuali satu golongan, yaitu AhI Sunnah wal Jama'ah. Tujuh puluh dua kelompok sempalan muslim yang dianggap sesat dan menyesatkan berada diluar tradisi Sunni sejati, menurut Nuruddin al-Raniri berasal dari enam golongan utama, yaitu: Rafidhiyah, Kharijiyah, Jabariyah, Qadariyah, Jahmiyah Murji'ah.

Selanjutnya, dijelaskan konsep-konsep tasawuf Ahl al-Haqq, yaitu Ahlullah yang berbeda dengan prinsip kaum Wujudiyah. Sebagaimana umumnya karya Nuruddin al-Raniri adalah menangkal kesalahpahaman konsep tasawuf oleh pengikut Hamzah Fansuri dan Syamsuddin as-Sumatrani.

\section{Keterangan}

Sampul depan naskah dari kertas tipis mengkilat warna coklat, pinggirannya tampak usang dan masih terjilid rapi bertuliskan arab "Al-Tibyan, li-Shaykh Nur al-Din al-Raniri". Terdapat coretan sebelum permulaan matan teks, kemungkinan dilakukan oleh pemilik (penyimpan) naskah. Naskah berbentuk prosa, sedangkan tulisan beraksara Arab berbahasa Jawi, gaya tulisan berbentuk khat naskhi dengan tinta warna hitam dan rubrikasi berwarna merah. Sedangkan 4 halaman terakhir kosong (tanpa coretan/tulisan), kecuali 1 halaman terakhir (h. 117) terdapat tulisan semacam ringkasan doa dan ajimat. 


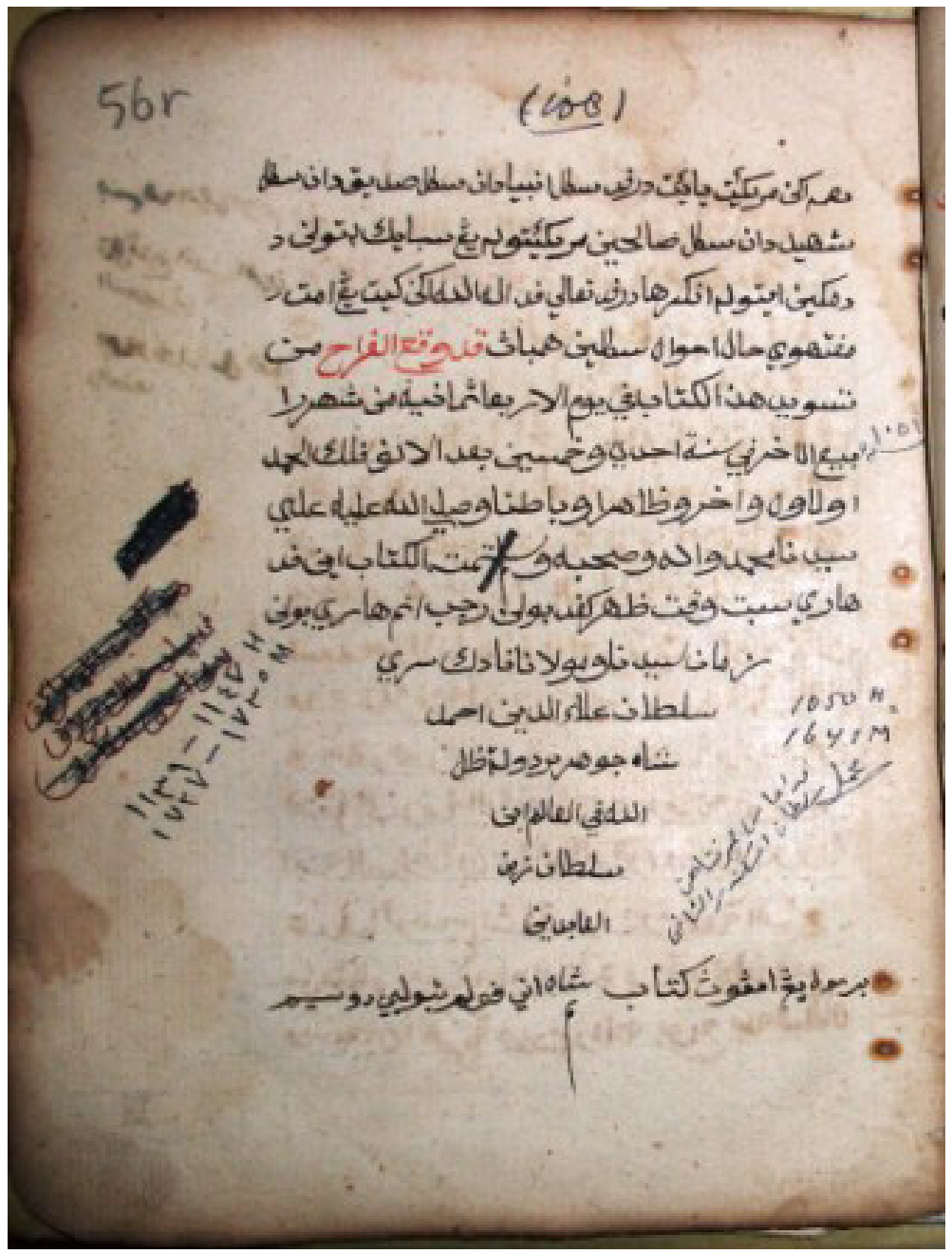

Halaman akhir Naskah Tibyan fi Ma'rifat al-Adyan 


\section{Kifayat al-Muhtajin}

00/TS/MNA-.607

Kertas Eropa

$\begin{array}{cc}\text { Jawi } & \text { Prosa } \\ 22 \times 15 \mathrm{~cm} & 14.5 \times 8 \mathrm{~cm}\end{array}$

$22 \times 15 \mathrm{~cm}$
$98 \mathrm{hlm}$

17 baris/hlm

\section{Pengarang}

Abdurrauf bin 'Ali al-Jawi al-Fansuri

\section{Penulisan}

\section{Kolofon}

\section{Cap Kertas}

Bulan Sabit Bersusun Tiga, tahun 1823-1824 M

\section{Gambaran Isi}

Naskah ini pertama membahas sifat wajib, mustahil, dan jaiz bagi Allah. Selanjutnya, membahas makna la ilaha illa Allah, fadhilat, dan kelebihan kalimat tersebut; adab berzikir, faedah, dan jenisnya. Selanjutnya, bacaan-bacaan salam tahlil, tahmid, zikir, samadiyah dan salawat kepada Nabi menurut pengarang, ajaran ini sesuai dengan ibadah penduduk Madinah "Demikianlah dikerjakan dan disuruhkan oleh Syeikh kita dalam Madinat al-Rasul".

\section{Keterangan}

Naskah ini telah direstorasi, sebelumnya kondisi naskah rusak di pinggiran kertas akibat dimakan rayap. Naskah ini tidak lengkap, halaman bagian awal dan akhir telah hilang, judul ini diperoleh dari perbandingan teks naskah lainnya. 


\section{[Hikayat Makrifat]}

00/TS/MNA-.534

$$
\text { Aceh }
$$

Prosa

$6 \mathrm{hlm}$

Kertas Eropa

$17 \times 10.5 \mathrm{~cm}$

$16 \times 9 \mathrm{~cm}$

14 baris/hlm

\section{Pengarang}

\section{Penulisan}

\section{Kolofon}

Tammat kalam uroe Ahad, ureung seumurah hana boe asoe [Tammat kalam hari Ahad, yang mensyarah isi tidak diberi identitas]. Tammat. Amin ya Allah.

\section{Cap Kertas}

\section{Gambaran Isi}

Naskah ini menguraikan tentang pengertian tauhid, iman, ihsan, syahadat, dan Islam. Pada bagian akhir terdapat uraian ajakan untuk beribadah, sekaligus digambarkan balasan akibat meninggalkan sembahyang, disebutkan dalam teks "Wahee aneuk ta ibadat, bek lalee that pitoek donya, donya teumpat piasan, han koen ba sajan seulama-lama, 'oh noe neujok oleh Tuhan... Uroe akhirat mukmin tempat lam surga, soe tan sembahyang dalam donya nyoe akhee dudoe lam neraka, lam neraka Jahannam keunan geupasoe, malam uroe ta doe ie mata" [Wahai anak, beribadahlah, jangan lalai dengan duniawi, dunia tempat hiburan saja, tidak akan dibawa selamanya, seginilah Tuhan beri kepada kita.. tempat mukmin di surga di hari akhirat nanti, tapi yang tidak shalat ditempatkan dalam neraka, neraka Jahannam tempatnya, siang malam air matanya tidak berhenti akibat siksaan]. 


\section{Keterangan}

Naskah ini memiliki dua halaman kosong di depan dan 4 di halaman akhir, tidak ada sampul naskah. Kondisi naskah baik, tulisan teksnya pun jelas dan ukuran lebih besar, seluruhnya memakai tinta hitam. Akan tetapi, kaidah penulisan agak rumit dan kurang rapi sehingga sulit dibaca.

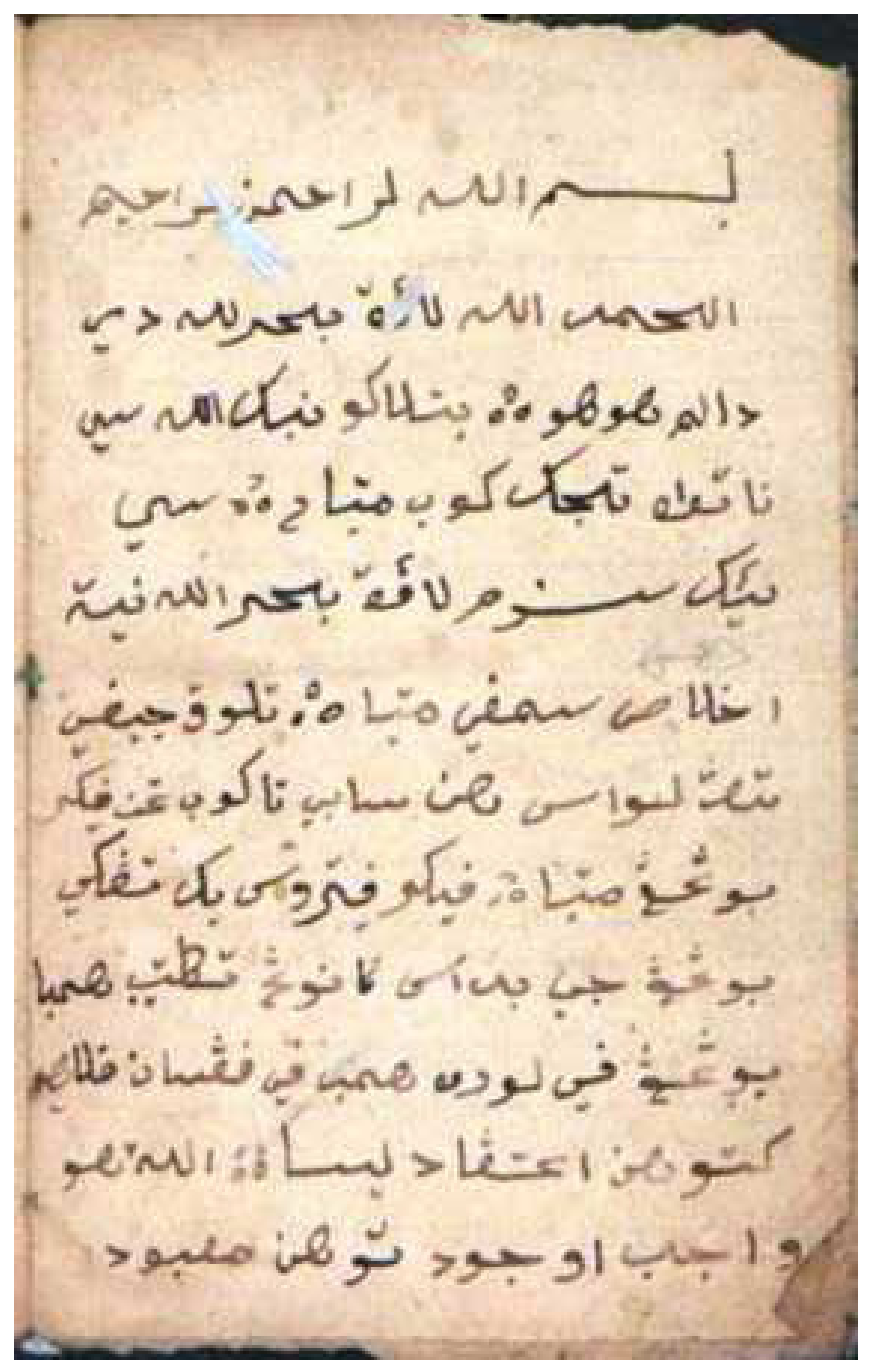

Halaman awal naskah Hikayat Makrifat 


\section{Dhurrat al-Nadhirah}

00/TS/MNA-.689

$$
\begin{gathered}
\text { Jawi } \\
21.5 \times 16.5 \mathrm{~cm}
\end{gathered}
$$

Prosa

$39 \mathrm{hlm}$

Kertas Eropa

$14 \times 8.5 \mathrm{~cm}$

17 baris/hlm

\section{Pengarang}

Siraj al-Din ibn Jalal al-Din

\section{Penulisan}

\section{Kolofon}

\section{Cap Kertas}

Bulan Sabit Bersusun Tiga, tahun 1823-1824 M

\section{Gambaran Isi}

Sesuai penyebutan oleh pengarang naskah Dhurrat al-Nadzirah tubayyinuha li-Durrat al-Fakhirah, yaitu penjelasan terhadap kitab Durrat al-Fakhirah. Alasan utama ia menulis kitab ini sebab banyak manusia yang hendak menelaah tentang sifat-sifat Tuhan, mustahil, jaiz, dan juga pada sifat-sifat Nabi.

Teks naskah menjelaskan sifat wajib dan hakikat bagi Allah, mustahil dan jaiz yang diklasifikasi sebagai berikut:

a. Sifat Nafsiyah; yaitu Wujud

b. Sifat Salbiyah; Qidam, Baqa, Mukhalafatuhu lil hawaditsi, Qiyamuhu binafsihi, Wahdaniyah

c. Sifat Ma'ani; Qudrat, Iradat, Ilmu, Hayat, Sami', Bashir, dan Kalam

d. Sifat Ma'nawiyah; Qadirun, Muridun, 'Alimun, Hayyun, Sami'un, Bashirun, dan Muttakalimun.

Selanjutnya, naskah menjelaskan sifat wajib, mustahil, dan jaiz pada Nabi, jumlah bilangan nabi dan rasul, martabat kenabian. 
Bab 2: Koleksi \& Katalogisasi: Naskah Tasawuf di Propinsi Aceh

\section{Keterangan}

Kondisi fisik naskah ini masih baik, hanya naskah ini tidak lengkap, karena tidak ada halaman akhir. Teks terbaca yang ditulis dengan khat naskhi berwarna hitam, sedangkan rubrikasinya berwarna merah. 


\section{Bahr al-Anwar}

00/TS/MNA-851/d/

Kertas Eropa
Aceh

$16 \times 11 \mathrm{~cm}$
Syair

$11 \times 8 \mathrm{~cm}$
$9 \mathrm{hlm}$

$11 \mathrm{baris} / \mathrm{hlm}$

\section{Pengarang}

\section{Penulisan}

\section{Kolofon}

\section{Cap Kertas}

Bulan Sabit Sejajar Bersusun Tiga (Venice, 1725)

\section{Gambaran Isi}

Naskah ini membahas keutamaan Nur Muhammad dan kemuliannya. Allah telah menciptakan nur Muhammad sebelum menciptakan seluruh alam ini dan termasuk nabi Adam. "Tajalli Tuhan bak Nur Muhammad jawab hadharat Qalu bala \# Tauhid sama 'oeh Makrifat sama kira meusa teubri bak mushalla \# Ruh ke imam jasad keu makmum bandua seun Allah Akbar\# Soe yang teum yakin nyata keu droe leumah rahsia \# Sayyidul Insan khairul Basyar Nur Nabi phoen mula nyata\# [Tajalli Tuhan kepada Nur Muhammad jawab hadharat Qalu bala\# Tauhid sama tempat dengan Makrifat di Mushalla\# Ruh jadi imam jasad jadi makmum keduanya menyebut Allah Akbar\# Siapa yang yakim demikian akan dibuka rahasia\# Sayyidul Insan Khairul Basyar, Nur Nabi yang pertama nyata].

\section{Keterangan}

Naskah bersampul karton tebal, teks naskah jenis naskhi berwarna hitam, jelas dan ukuran teks agak besar, di dalamnya terdapat alihan kata. Teks ini tergabung dengan beberapa tema yang serupa tentang tasawuf, namun tidak terdapat nama penulis ataupun pengarang naskah. 


\section{[Tasawuf]}

$\begin{array}{cccc}\text { 00/TS/MNA-.851/e/ } & \text { Aceh } & \text { Syair } & 12 \mathrm{hlm} \\ \text { Kertas Eropa } & 16 \times 11 \mathrm{~cm} & 11 \times 8 \mathrm{~cm} & 11 \mathrm{baris} / \mathrm{hlm}\end{array}$

\section{Pengarang}

\section{Penulisan}

\section{Kolofon}

\section{Cap Kertas}

Bulan Sabit Sejajar Bersusun Tiga (Venice, 1725)

\section{Gambaran Isi}

Teks ini mengandung tasawuf falsafi tingkat tinggi, walaupun hanya dibahas secara singkat dan dalam bentuk nazam. Teks dimulai dengan kesaksian, permohonan ampun dari segala dosa, memelihara diri dan jiwa, adab, diberi hidayah dan keselamatan, keberkatan para nabi-nabi, berkat tongkat Nabi Musa, berkat cincin Nabi Sulaiman, berkat para malaikat, kaum sufi, dan anjuran berzikir. Di penutup teks disebutkan "Dalam kitab asai ahlu Sufi, zikir geuyu barang kajan, nama zikir nan hasanat wahai sahabat soe nay akin, habeh kalam khabar najah, oeh nan tamat sempurna. Amin, amin, amin".

\section{Keterangan}

Naskah ini bersampul karton tebal warna hitam dalam kondisi baik, ditulis teks jenis naskhi berwarna hitam dan jelas. Seluruh halaman memiliki alihan kata. Teks ini tergabung dengan beberapa tema yang serupa tentang tasawuf, namun tidak terdapat nama penulis ataupun pengarang naskah. 


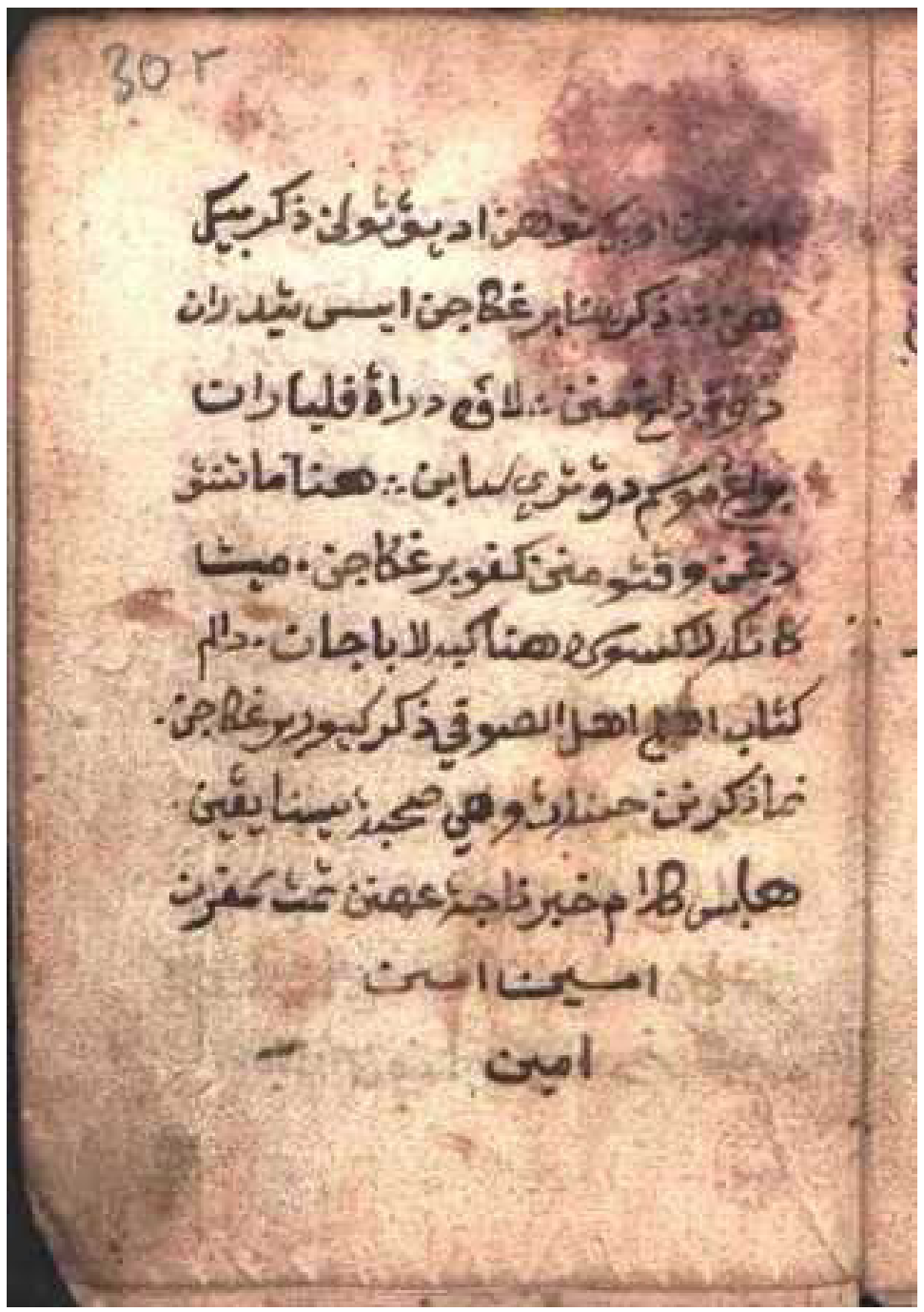

Halaman naskah teks Tasawuf 


\section{[Berkat Syeikh]}

00/TS/MNA-851/c/2012

$$
\text { Jawi }
$$

Prosa

$6 \mathrm{hlm}$

Kertas Eropa

$16 \times 11 \mathrm{~cm}$

$11 \times 8 \mathrm{~cm}$

$11 \mathrm{baris} / \mathrm{hlm}$

\section{Pengarang}

\section{Penulisan}

\section{Kolofon}

\section{Cap Kertas}

Bulan Sabit Sejajar Bersusun Tiga (Venice, 1725)

\section{Gambaran Isi}

Naskah ini membahas tentang permohonan keberkahan dari Syeikh-Syeikh tarekat dan tasawuf sebelumnya. Beberapa nama disebutkan di dalam teks, seperti Syeikh Ahmad al-Qusyasyi, Syeikh Imam Ahmad al-Tsanawi, Syeikh Rasyid Shibgatallah, Wajhuddin 'Alawi, Sayyid Muhammad Ghaus, Syeikh Haji Huzhur, Syeikh Hidayatullah, Syeikh 'Alauddin, Syeikh Abdurrauf al-Qadir, Syeikh Mahmud al-Qadiri, Syeikh Abd al-Ghafar, Syeikh Muhammad al-Qadiri, hingga sampai kepada berkah Amirul Mukminin 'Ali Murtadha dan Nabi Muhammad SAW.

\section{Keterangan}

Naskah bersampul karton tebal, teks naskhi berwarna hitam, terdapat alihan kata, dan terdapat halaman kosong di tengah naskah. Teks ini tergabung dengan beberapa tema yang serupa serupa tasawuf, namun tidak terdapat judul, demikian juga dengan penulis ataupun pengarang naskah. Teks naskah ini menjadi penting karena terdapat beberapa nama tokoh sufi (tasawuf) dan ajaran-ajaran yang mereka amalkan, terlebih lagi yang berkembang di Aceh. 


\section{Tuhfat al-Ahbab}

00/TS/MNA-712/b/2012

Jawi

Prosa

$8 \mathrm{hlm}$

Kertas Eropa

$23.5 \times 17 \mathrm{~cm}$

$15.5 \times 11 \mathrm{~cm}$

23 baris/hlm

\section{Pengarang}

Abd al-Rahman al-Bawani

\section{Penulisan}

\section{Kolofon}

Dan selesai faqir yang tertib itu daripada mengarang risalah ini waktu Ashar. Amin ya rabb al-'alamin. Amin. Inilah yang bernama akan dia Tuhfat al-Ahbab. Amin.

\section{Cap Kertas}

Bulan Sabit Bersusun Tiga, sekitar tahun 1725 M (Andrea Gilvani)

\section{Gambaran Isi}

Naskah ini menjelaskan tentang zat Allah, selanjutnya membahas tentang martabat dalam tasawuf, di bagi kepada tujuh martabat. Pertama, Ahadiyah disebut juga martabat hakikat Allah. Kedua, Wahdat. Ketiga, Wahidiyyah, disebut juga A'yan Tsabitah. Keempat, Alam Arwah, disebut juga A'yan Kharijiyah. Kelima, Alam Mitsal. Keenam, Alam Ajsam atau disebut juga Alam Syahdat. Ketujuh, dikenal Alam Insan.

Selanjutnya, teks membahas bacaan zikir dalam martabat tasawuf, kalimat yang dibaca "la ilaha illa Allah", dan selanjutnya kepada tingkatan mubtadi la ma'bud illa Allah, tingkatan mutawassith la matlub illa Allah, dan tingkatan muntahi la maujudilla Allah.

Bagian akhir dari teks ini disebutkan silsilah tarekat Syattariyahyang diterima oleh Abdurrahman al-Bawani daripada Syeikh Abdurrauf anak Ali Fanshuri, ia daripada Ahmad Qusyasyi, dan seterusnya. 
Bab 2: Koleksi \& Katalogisasi: Naskah Tasawuf di Propinsi Aceh

\section{Keterangan}

Teks naskah ini menyatu dengan beberapa teks naskah lainnya. Naskah ini tergolong baik, ditulis dengan rapi, jelas dan terdapat alihan kata. Bentuk teks naskhi ditulis dengan tinta hitam dan rubrikasi merah.

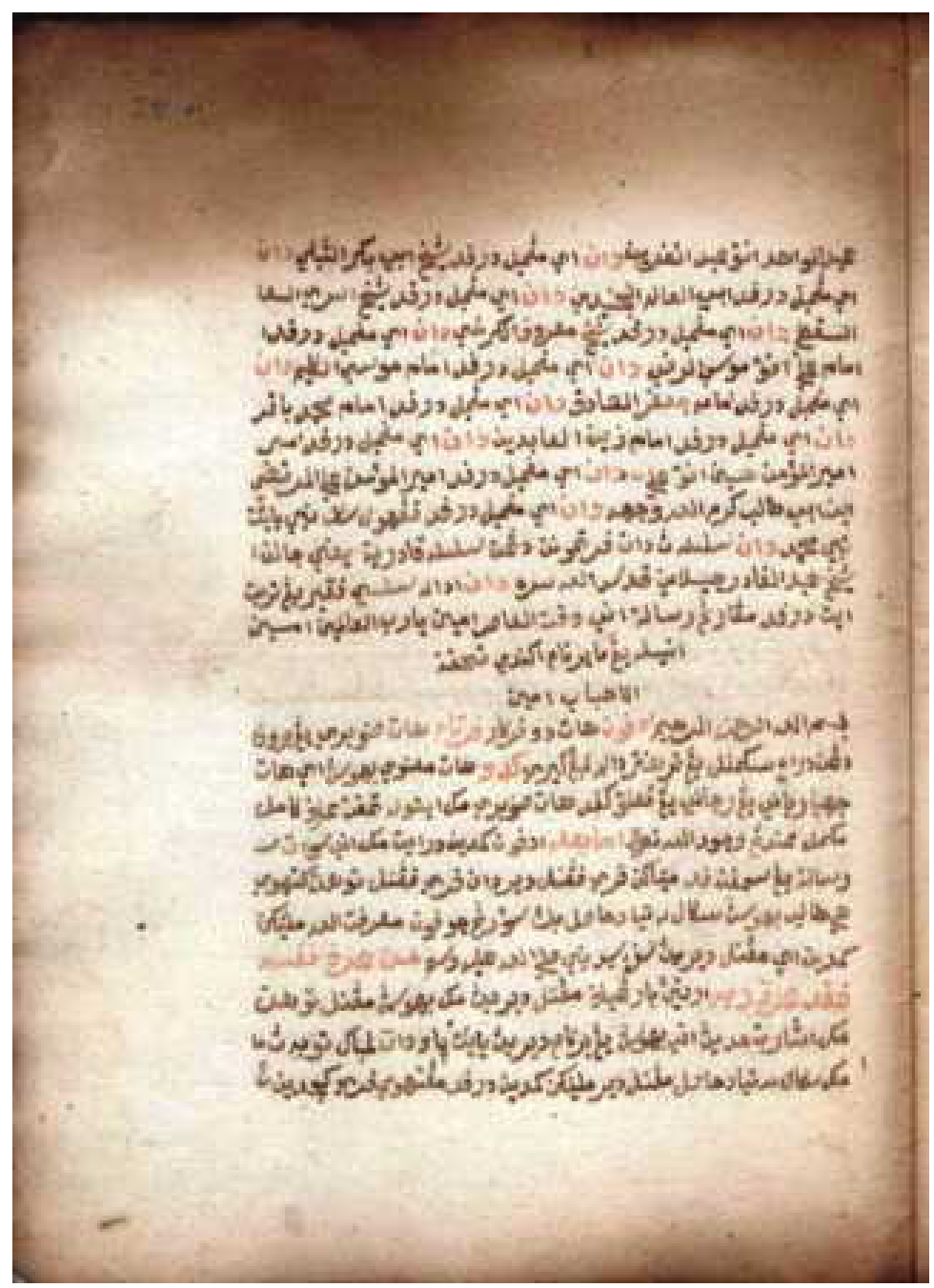

Halaman akhir teks naskah Tuhfat al-Ahbabi 


\section{Makrifat al-Haqq al-Mubin}

$\begin{array}{cccc}\text { 00/TS/MNA-1261/2012 } & \text { Jawi dan Aceh } & \text { Prosa } & 17 \mathrm{hlm} \\ \text { Kertas Eropa } & 21.5 \times 15 \mathrm{~cm} & 15.5 \times 10.5 \mathrm{~cm} & 17 \mathrm{baris} / \mathrm{hlm}\end{array}$

\section{Pengarang}

\section{Penulisan}

\section{Kolofon}

\section{Cap Kertas}

Al-Masso, Sekitar tahun 1822-1823, Edward Heawood, h. 502 no. 3748

\section{Gambaran Isi}

Pada permulaan teks menngunakan bahasa Jawi, selanjutnya mayoritas menggunakan bahasa Aceh. Naskah ini menguraikan tentang makrifat, iman, dan sifat-sifat Allah dalam bentuk tanya jawab. Pada bagian awal menyoal berbagai hal pengertian tentang makrifat dan keutamaannya. Selanjutnya, seputar sifat-sifat bagi Allah dan tentang iman.

\section{Keterangan}

Teks naskah ini terjilid rapi dengan teks lainnya tentang bab nikah. Sampul naskah dari kain warna coklat tua, sudah dimakan rayap di bagian bawah. Terdapat dua halaman kosong di awal teks, dua belas di halaman tengah dan empat di halaman akhir. Naskah ditulis dalam aksara Arab-Jawi dengan khat naskhi menggunakan teks tinta hitam dan rubrikasi warna merah. 


\section{Nujum al-Huda li Ahl al-Qurba}

$\begin{array}{cccc}\text { 00/TS/MNA-785/2012 } & \text { Jawi } & \text { Prosa } & 7 \mathrm{hlm} \\ \text { Kertas Eropa } & 16 \times 11.5 \mathrm{~cm} & 14.8 \times 9 \mathrm{~cm} & 27 \mathrm{baris} / \mathrm{hlm}\end{array}$

\section{Pengarang}

\section{Penulisan}

\section{Kolofon}

\section{Cap Kertas}

Bulan Sabit Bersusun Tiga, tahun 1823-1824 M

\section{Gambaran Isi}

Teks ini memberikan penjelasan tentang konsep martabat tujuh, yang terdiri dari: ahadiyah, wahdah, wahidiyah, alam arwah, alam mithal, alam ajsam, dan insan kamil. Semua sifat Allah yang dua puluh terkait, secara proporsional dengan martabat ahadiyah, wahdah, dan wahidiyah.

Hal yang juga ditegaskan dalam teks ini adalah tentang keharusan adanya keseimbangan dalam mempelajari ilmu tasawuf (hakikat) dan ilmu syariat (fiqih). Ditegaskan dalam teks tersebut, bahwa "sekali-kali tiada sempurna ilmu melainkan engkau menunaikan syariat dan hakikat". Oleh karenanya, selain masalah-maslah tasawuf, dalam teks ini juga dijelaskan tentang hukum-hukum halal, haram, wajib, sunnah, makruh, dan mubah.

Pada bagian lain disebutkan, bahwa Al-Qur'an itu diturunkan atas tujuh huruf, yang masing-masing memiliki makna lahir dan makna batin. Ketujuh huruf tersebut adalah: hamzah, yang berarti amar (perintah); nun, yang berarti nahyi (larangan); ha, yang berarti halal; ra, yang berarti haram; waw, yang berarti wajib; sin, yang berarti sunnah; dan mim, yang berarti makruh. Sebagian ulama menambahkan huruf jim, yang berarti jawaz (boleh). 


\section{Keterangan}

Kondisi naskah ini masih baik dan terbaca, masih terjilid dengan benang, namun tidak ada sampul. Teks naskah ditulis dengan khat naskhi, ukuran agak kecil, menggunakan tinta warna hitam dan rubrikasi merah. Di bagian akhir halaman naskah ini terdapat tujuh halaman kosong.

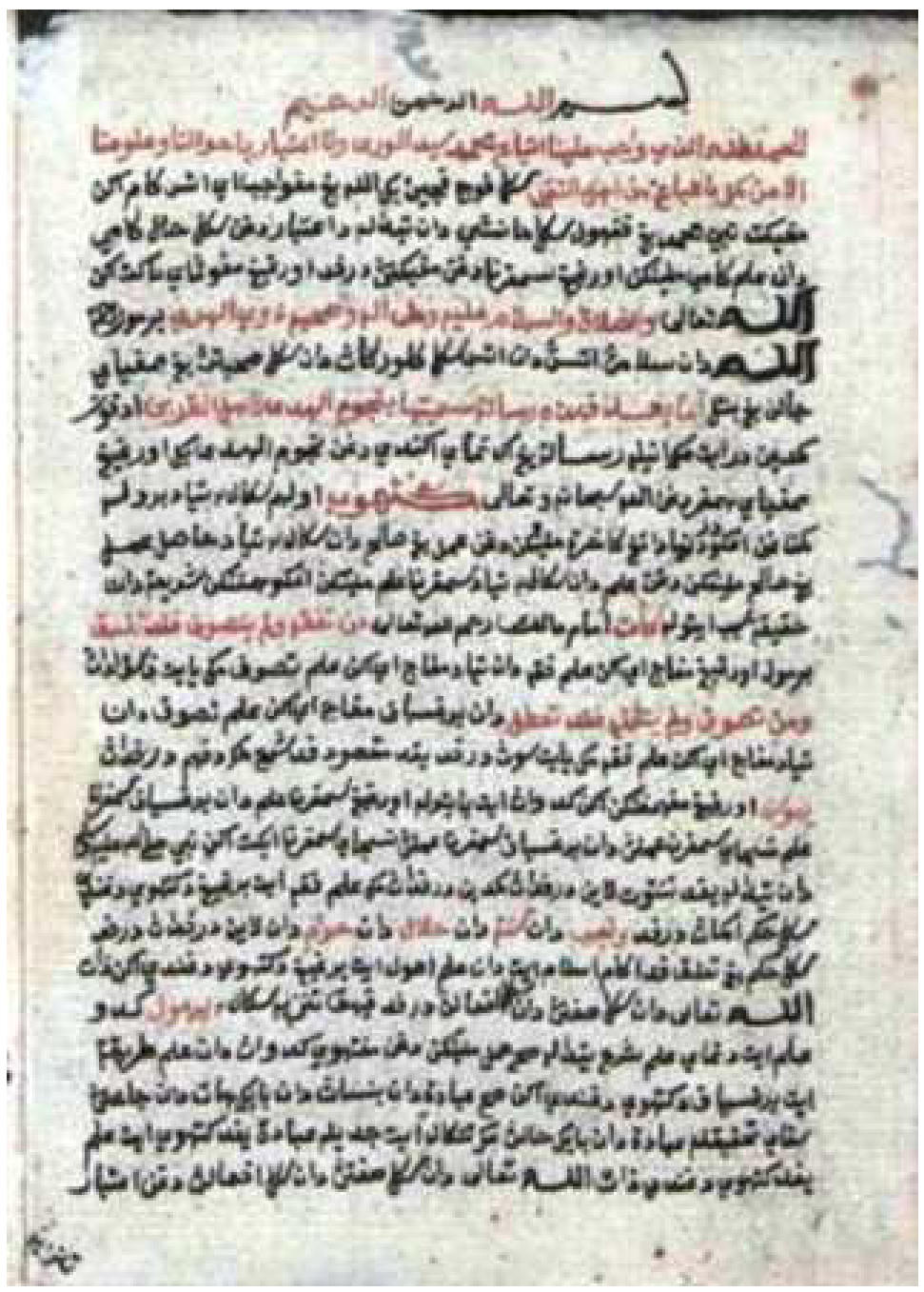

Halaman awal naskah Nujum al-Huda li Ahl al-Qurba 


\section{Thariqat Syattariyyah}

$\begin{array}{cccc}\text { 00/TS/BW5/2012 } & \text { Arab \& Jawi } & \text { Prosa } & 16 \mathrm{hlm} \\ \text { Kertas Eropa } & 16.5 \times 10.5 \mathrm{~cm} & 14 \times 9 \mathrm{~cm} & 11,13,14 \mathrm{baris} / \mathrm{hlm}\end{array}$

\section{Pengarang}

\section{Penulisan}

\section{Kolofon}

\section{Cap Kertas}

\section{Gambaran Isi}

Naskah ini membahas tatacara berzikir dan beristighfar sesuai dengan tuntunan dalam tarekat Syattariyah. Disebutkan, bahwa saat mengucapkan shalawat kepada Nabi Muhammad, diharapkan dapat memejam matanya hingga sampai kepada zikir la ilaha illa Allah sebanyak seratus kali. Selanjutnya, zikir tersebut ditutup dengan doa.

Dalam naskah ini disebutkan silsilah tarekat Syattariyah yang diterima oleh Idris bin 'Amr Lahwe, daripada faqir yang hina Abdul Ghani Lampisang, hingga kepada Haji Abdul Wahhab Tanoh Abee, seterusnya beberapa tingkat ke atas hingga kepada Maula Ibrahim al-Kurani daripada Syeikh Ahmad al-Qusyasyi. Kedua nama terakhir adalah guru dan afiliasi silsilah Tarekat Syattariyah Abdurrauf alJawi al-Fansuri al-Singkili, ulama masyhur abad ke-17 M.

Pada bagian selanjutnya dijelaskan keutamaan surat al-lkhlas yang merujuk kepada hadis Nabi Muhammad.

Di dalam naskah ini juga disebutkan silsilah talqin yang diperoleh Idris bin 'Amr Lahwe dari Abdul Ghani Lampisang. 


\section{Keterangan}

Naskah ini koleksi masyarakat bernama Bang Wan di Pidie, sesuai kandungannya naskah ini lengkap, dan kondisi fisik naskah juga terpelihara, teksnya terbaca. Walaupun terdapat beberapa lobang akibat bakteri, naskah ini masih terjilid rapi. Setiap halaman memiliki alihan kata, ditulis dengan khat naskhi, warna teks hitam, kecuali rubrikasi menggunakan tinta berwarna merah. 
Hijrat al-Insan

00/TS/MNA-399/2012

$\begin{array}{ccc}\text { Jawi } & \text { Prosa } & 130 \mathrm{hlm} \\ 15.5 \times 10 \mathrm{~cm} & 9 \times 5 \mathrm{~cm} & 9 \text { baris } / \mathrm{hlm}\end{array}$

\section{Pengarang}

Syeikh Qutub al-Aqtab?

\section{Penulisan}

$1260 \mathrm{H}[1844 \mathrm{M}]$

\section{Kolofon}

Fi hijrat Nabi shalla Allah 'Alaihi Wasallam Sittina ba'da Mi'ataih waAlfin, intaha ar-risalah. Pada hijrah Nabi Shalla Allah 'Alaihi Wasallam seribu dua ratus nam puluh tahun, itulah sempuran taklif risalah ini.

\section{Cap Kertas}

Bunga, (tahun tidak diketahui)

\section{Gambaran Isi}

Naskah ini mengurai tentang suluk dalam tasawuf, khususnya mencapai martabat ahadiyah. Martabat ahadiyah merupakan martabat tingkat pertama, yaitu disebut juga la ta'yin (tidak nyata) atau disebut juga dengan wujud sunyi dari segala sifat dan bentuk kaitannya. Dalam naskah ini dijelaskan, bahwa martabat ahadiyah adalah martabat Allah yang berupa zat qadim azali, masih bersifat belum nyata, pada konsep martabat ini menjelaskan keberadaan Allah merupakan hakikat dari [nur] Muhammad.

Pada teks naskah ini juga menjelaskan tujuh alam. Di antaranya, alam lahut, alam jabarut, alam malakut, alam ruh, alam mitsal, alam ajsam, dan alam insan. Disebutkan"Ketujuh alam insan, yaitu martabat segala makhluk zahir batin inilah ini".

Kemudian, teks naskah ini mengajak kepada mubtadi suluk untuk berguru kepada seorang Syeikh yang benar-benar dalam tasawuf, 
sehingga apabila ia tidak memiliki Syeikh, maka setan-lah yang menjadi gurunya. Maka, setiap guru (Syeikh) memiliki kriteriakriterianya tersendiri.

\section{Keterangan}

Halaman depan naskah tertulis "bi-syeikh Qutb al-Nafi' al-hakim al-shalih", selanjutnya inilah alamat kitab Hijrat al-Insan daripada ilmu suluk orang...". Naskah terjilid dengan kuat bersampul kulit binatang. Kondisi naskah rusak di pinggir halaman, dan tidak merusak teks naskah. Teks naskah ini tergabung dengan ayat AlQur'an surat Yasin, doa-doa dan fadhilah membaca la ilaha illa Allah. 
Bab 2: Koleksi \& Katalogisasi: Naskah Tasawuf di Propinsi Aceh

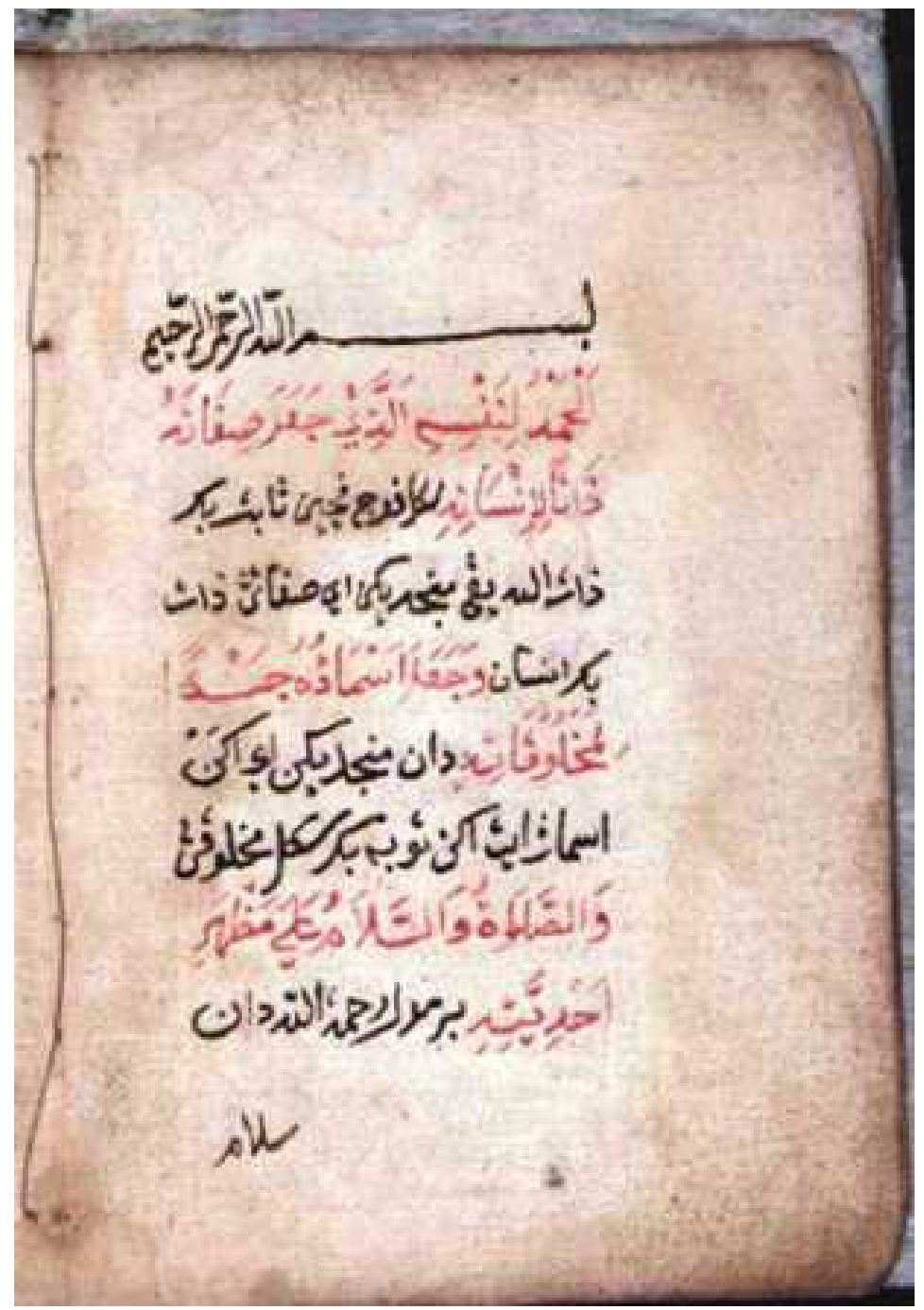

Halaman awal naskah Hijrat al-Insan 
[Zikir Tarekat Syattariyyah dan Qadariyyah]

00/TS/MNA-506/c/2012

Jawi

Prosa

$5 \mathrm{hlm}$

Kertas Eropa

$22 \times 16 \mathrm{~cm}$

$17 \times 8 \mathrm{~cm}$

17 baris/hlm

\section{Pengarang}

Abdurrauf bin Ali al-Jawi al-Fansuri

\section{Penulisan}

\section{Kolofon}

Wa-shahibu hadha al-kitab Teungku Tanjong. Amin. Amin.

\section{Cap Kertas}

\section{Gambaran Isi}

Teks ini berisikan tentang doa zikir yang digunakan dalam Tarekat Syattariyyah dan Qadariyyah, disertai dengan ittishal silsilah tarekat kedua yang berasla dari negeri Yaman dan Makkah al-Mukarramah. Ada dua Syeikh utama dalam membangun dua tarekat utama tersebut. Pertama, Syeikh dalam tarekat Syattariyah bernama 'Abdullah Syattari. Kedua, Syeikh dalam tarekat Qadariyyah bernama Abdul Qadir al-Jailani.

Dalam teks naskah ini juga disebutkan silsilah guru-guru tarekat yang diterima oleh Abdurrauf bin Ali al-Jawi al-Fansuri.

\section{Keterangan}

Teks naskah ini disalin oleh Teuku Tanjong 


$$
\begin{array}{cccc}
\multicolumn{4}{c}{\text { Manazil al-Sa'irin ila Allah al-Malik al-Mubin }} \\
\text { 00/TS/MNA-1127/b/ } 2012 & \text { Arab } & \text { Prosa } & 235 \mathrm{hlm} \\
\text { Kertas Eropa } & 23 \times 17 \mathrm{~cm} & 18.5 \times 10.5 \mathrm{~cm} & 11,12 \mathrm{baris} / \mathrm{hlm}
\end{array}
$$

\section{Pengarang}

Syeikh Isma'il Abdullah bin Muhammad al-Harawi al-Anshari

\section{Penulisan}

Awal 1298 H (1880 M), Tahun Dal

\section{Kolofon}

Wa-hadza al-kitab milik hak Abi Ismail al-Ramawi Mas'ud ibn Abd al-Ghafur al-Ramawi radhiallah 'anhum wa-rahmat Allah 'alaihim. Tamma, 1298 Sanah Dal Al-Awwal.

\section{Cap Kertas}

Bulan Sabit Tersenyum dalam Perisai

\section{Gambaran Isi}

Teks ini mengkaji secara terperinci tentang tasawuf, di antara isinya tentang maqam-maqam yang dilalui seorang sufi. Pengarang menjelaskan antara hamba dan al-haq terdapat seratus maqam yang dibagi dalam sepuluh bagian, setiap bagian terdapat tatacara dan metode yang harus ditempuh oleh seorang salik.

Bagian-bagian (juz) tersebut, yaitu bagian al-bidayat, al-abwab, al-mu'amalat, al-akhlaq, al-ushul, al-awdiyah, al-ahwal, al-wilayat, al-haqa'iq, dan al-nihayat. Setiap penjelasan bagian (juz) tersebut terdiri dari 10 pasal (bab) yang membahas tentang tasawuf secara terperinci berdasarkan dalil kitab dan hadis, serta pendapat ulama.

\section{Keterangan}

Catatan awal dari teks ini disebutkan "wa-hadza kitab Manazil alSa'irin ila Allah al-Malik al-Mubin li-Syeikh al-Kamil al-Mukammil al- 
'arif al-muhaqqiq Abu Isma'il 'Abdullah ibn Muhammad al-Harawi alAnshari qaddasa Allah sirrahu waruhahu".

"Wa-hadha al-kitab milik hak Abi Ismail al-Ramawi Mas'ud ibn Abd al-Ghafur al-Ramawi radhiallah 'anhum wa-rahmat Allah 'alaihim. Tamma, 1298 Sanah Dal al-Awwal".

Teks ini memiliki syarah (penjelasan) yang ditulis dengan bahasa Arab di kertas biasa dengan tinta hitam. Halaman-halaman tersebut diselip di antara teks naskah. Naskah ditulis dengan tinta warna hitam saja, termasuk lembaran penjelasan teks. 


\section{Syifa' al-Qulub}

00/TS/MNA-1658/c/2012

$$
\text { Jawi }
$$

Prosa

$5 \mathrm{hlm}$

Kertas Eropa

$17 \times 11 \mathrm{~cm}$

$14 \times 7 \mathrm{~cm}$

13 baris/hlm

\section{Pengarang}

Nur al-Din bin 'Ali bin Hasanji Muhammad Hamid ar-Raniri

\section{Penulisan}

\section{Kolofon}

\section{Cap Kertas}

Bulan Sabit Tersenyum dalam Perisai

\section{Gambaran Isi}

Teks ini merupakan kritikan Nuruddin terhadap penyalah tafsiran kalimat la ilaha illa Allah oleh kelompok Wujudiyah. Dalam mukaddimahnya, ia menyatakan "maka tatkala kulihat diubahkan kaum Wujudiyah akan makna La ilaha illa Allah itu serta dihelanya kepada itikad yang sesat." Teks ini adalah melengkapi beberapa risalah (kitab) sederhana dan tipis yang dikarang oleh Nuruddin ar-Raniry atas konsistensinya terhadap persekusi kelompok Wujudiyah.

\section{Keterangan}

Teks naskah ini terdapat pada urutan ketiga dari enam teks dalam satu bundel. Halaman akhir teks naskah ini tidak ada, dan alas tulis dalam bundel naskah in ijuga tidak teratur, walaupun naskah ini tersampul dengan karton tebal berwarna coklat tua. 


\section{Tarekat Naqsyabandiyah}

00/TS/MNA-1658/e/2012

$\begin{array}{ccc}\text { Jawi } & \text { Prosa } & 9 \mathrm{hlm} \\ 17 \times 11 \mathrm{~cm} & 14 \times 7 \mathrm{~cm} & 15 \text { baris } / \mathrm{hlm}\end{array}$

Kertas Eropa

$17 \times 11 \mathrm{~cm}$

$4 \times 7 \mathrm{~cm}$

\section{Pengarang}

\section{Penulisan}

\section{Kolofon}

\section{Cap Kertas}

Bulan Sabit Tersenyum dalam Perisai

\section{Gambaran Isi}

Teks naskah ini mengurai tatacara berzikir dalam Tarekat Naqsyabandiyah. Selain itu, ada beberapa ketentuan yang harus ditempuh oleh para murid Naqsyabandiyah, disebutkan "inilah setengah bagi silsilah daripada masya'ikh bagi orang yang menzikir atas tarekat jalan Naqsyabandiyah bagi rupa yang setengah daripada tarekat ini apabila masuk ia pada waktu zikir tedapat tiada ia daripada air sembahyang, dan mengadap kiblat, dan memejam matanya, dan menahan nafasnya serta mengencang giginya dan hendak kita mengambil akan zikirnya daripada pusatnya hingga kita naik ke atas lambung kanan..."

Dalam teks juga disertakan doa yang harus (wajib) dibaca oleh para salik, dan bacaan surat al-Fatihah ditujukan kepada ulama (Syeikh) dalam tarekat ini, Sayyid Qutb Rabbani, 'Arif as-Shamadani, Haikal al-Nurani, Syeikh Mushtafa al-Baqi, Syeikh Abdullah Syarqawi dan Syeikh Muhammad Ali.

Selanjutnya, anjuran kepada murid yang harus diikuti (taati), dimana disebutkan, bahwa tertib guru mengajarkan muridnya zikir serta bai'at, maka hendaklah gurunya menyuruhkan muridnya...". 


\section{Keterangan}

Teks naskah ini terdapat pada urutan kelima dari enam teks dalam satu bundel. Halaman akhir teks naskah ini tidak ada, dan alas tulis dalam bundel naskah in ijuga tidak teratur, walaupun naskah ini tersampul dengan karton tebal berwarna coklat tua.

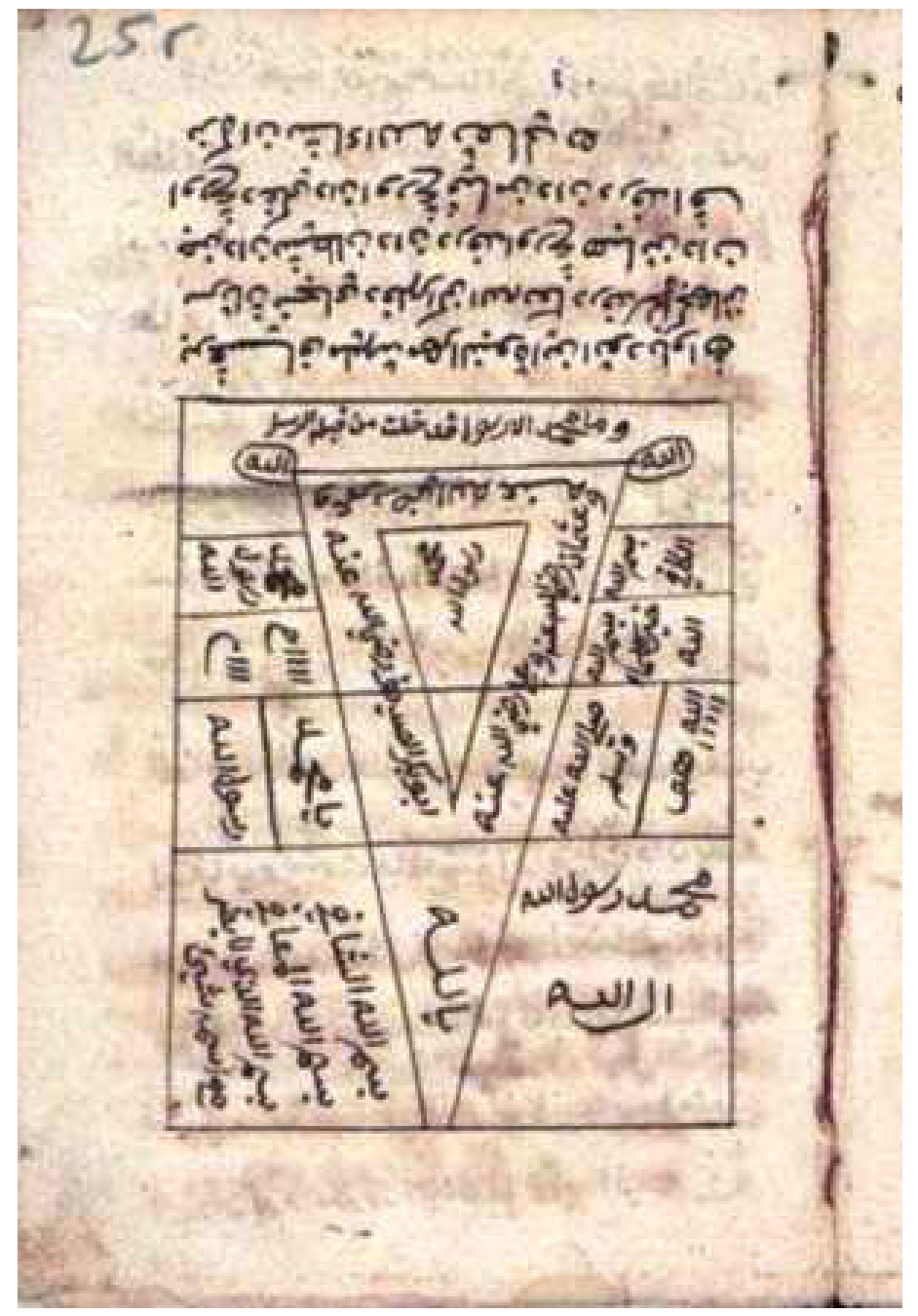

Salah satu halaman dalam bundel naskah

Tarekat Naqsyabandiyah 


\section{Thariq al-Din}

00/TS/MNA-338/A/2012

$\begin{array}{ccc}\text { Jawi } & \text { Prosa } & 59 \mathrm{hlm} \\ 22 \times 15.5 \mathrm{~cm} & 16 \times 10 \mathrm{~cm} & 17 \text { baris } / \mathrm{hlm}\end{array}$

Kertas Eropa

\section{Pengarang}

Muhammad Ali ibn Sari

\section{Penulisan}

\section{Kolofon}

\section{Cap Kertas}

Bulan Sabit Bersusun Tiga (Venice, 1725)

\section{Gambaran Isi}

Naskah ini memiliki dua pasal (bab). Pertama, tentang shalat secara jasad dan yang berhubungan dengannya. Dijelaskan bahwa shalat merupakan tiang agama, dan bahwa agama ini merupakan makrifat, jalan untuk menuju makrifat itu adalah shalat. Selanjutnya, penulis mulai mengulas bacaan-bacaan dalam shalat dan rukun shalat secara filosofis, atau di dalam teks dimaksud Isyarah, terutama diIsyarahkan kepada Nabi Adam as.

Kedua, mendefinisikan shalat secara ruh dan yang berkaitan dengannya, disebutkan bahwa "rak'atani min al-'arif khair min alfi rak'ati min al-zahid".

\section{Keterangan}

Pada dasarnya, judul naskah ini Thariq al-Din li-dzat li-man hadhab nafsuhu fi shalat, namun kemudian pengarang mengulangnya dan menyebut Thariq al-Din. Halaman awal naskah ini terpotong, sepertinya ada kesengajaan menghilangkan ilustrasi di halaman depan naskah. Naskah ini merupakan kumpulan teks, bagian awal dan akhir teks tidak lengkap dan tidak bersampul. Terdapat satu halaman kosong di dalamnya. 


\section{Bayan al-Thariq li-man Salak ila Dhat al-'Amiq}

$\begin{array}{cccc}\text { 00/TS/MNA-338/B/2012 } & \text { Jawi \& Aceh } & \text { Prosa } & 46 \mathrm{hlm} \\ \text { Kertas Eropa } & 22 \times 15.5 \mathrm{~cm} & 16 \times 10 \mathrm{~cm} & 17 \mathrm{baris} / \mathrm{hlm}\end{array}$

\section{Pengarang}

\section{Penulisan}

\section{Kolofon}

\section{Cap Kertas}

Bulan Sabit Bersusun Tiga (Venice, 1725)

\section{Gambaran Isi}

Sebagaimana pada pembukaan kitab ini, bahwa penulis mengarang kitab ini sebab pertanyaan saudaranya tentang sempitnya pengetahuan terhadap ilmu ketuhanan. Naskah ini dibagi kepada empat pasal (bab). Pertama, tentang Martabat al-Haq, yaitu terbagi kepada tujuh martabat; ahadiyah, wahdah, wahidiyyah, 'alam arwah, 'alam mitsal, 'alam ajsam dan 'alam insan.

Kedua, tentang martabat al-Khalaq, jumlah pembagiannya sama dengan bab sebelumnya.

Ketiga, fi Thalaq al-kaunain bi-tsalatsi thalaq dan bab terakhir tentang tha'am al-ruh wa al-jasad.

Pada penutup (khatimah) diuraikan tentang kalimat la ilaha illa Allah. Penjelasannya dalam bahasa Aceh aksara Jawi.

\section{Keterangan}

Naskah ini merupakan kumpulan teks, teks judul ini berada pada urutan kedua dari empat judul teks. Sedangkan naskahnya tidak memiliki sampul. Di dalamnya terdapat ilustrasi tentang tasawuf, yaitu menyangkut ruh dan a'yan tsabitah. 


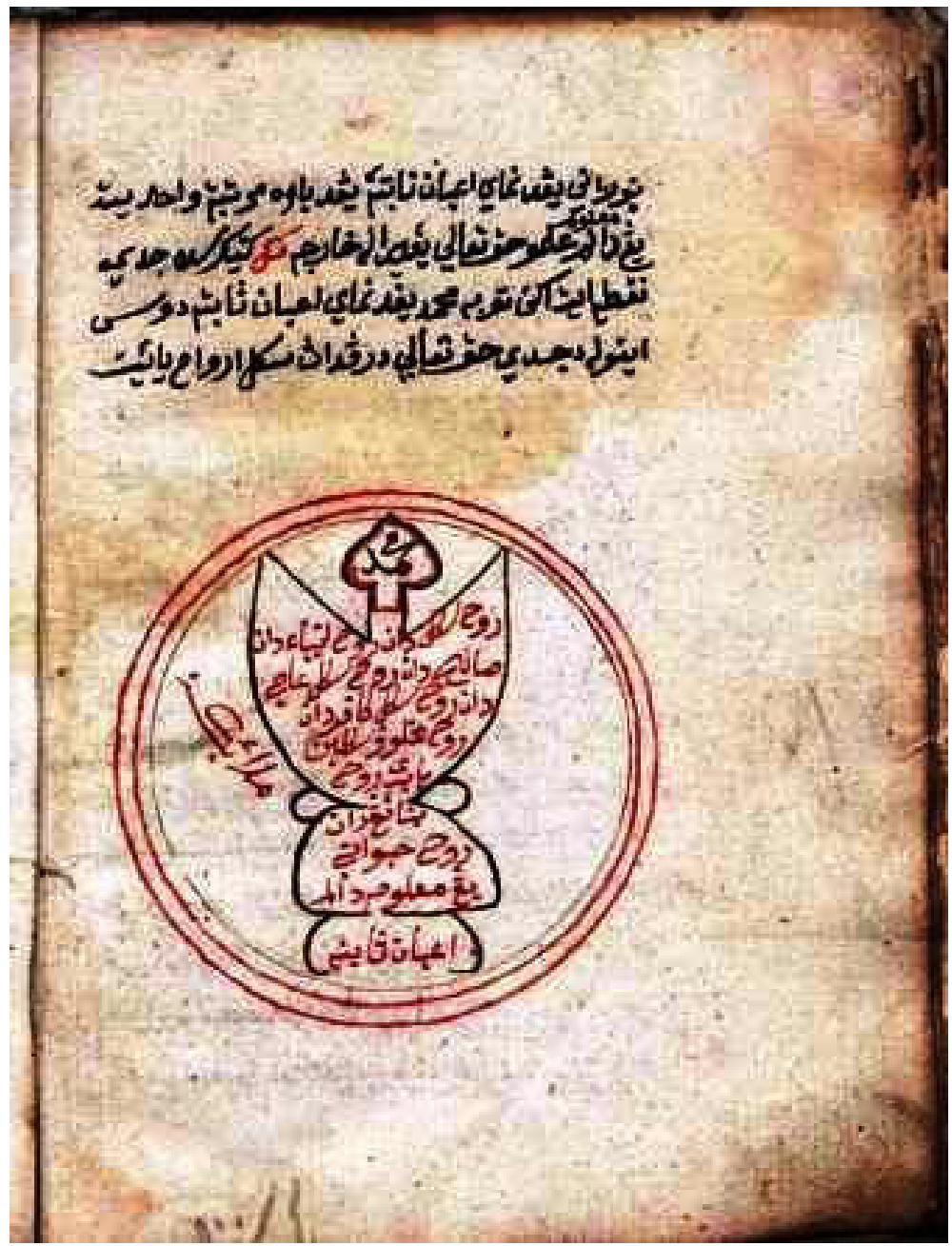

Halaman naskah

Bayan al-Thariq Liman Salaka ila Dhat al-'Amiq 


\section{[Nazam Tasawuf Aceh]}

$\begin{array}{cccc}\text { 00/TS/MNA-547/2012 } & \text { Arab \& Aceh } & \text { Syair } & 40 \mathrm{hlm} \\ \text { Kertas Eropa } & 12 \times 8 \mathrm{~cm} & 7.5 \times 4 \mathrm{~cm} & 11 \mathrm{baris} / \mathrm{hlm}\end{array}$

\section{Pengarang}

\section{Penulisan}

\section{Kolofon}

\section{Cap Kertas}

Bulan Sabit Bersusun Tiga

\section{Gambaran Isi}

Naskah ini membahas seputar tasawuf yang diutarakan dalam bentuk syair-syair dalam bahasa Arab yang diterjemahkan ke dalam bahasa Aceh, kandungan isinya dikutip dari ayat-ayat AlQur'an dan hadis Nabi. Di awal pembahasan telah menceritakan kedudukan antara tarekat, hakikat, dan makrifat, zat Allah dan nur Muhammad yang lahir dan batin, i'tikad, mustahil, wujud Tuhan, tanzih, tasybih, a'yan tsabitah, alam, dzahir dan ghaib, serta tujuh martabat; ahadiyah, wahdah, wahidiyyah, 'alam arwah, 'alam mitsal, 'alam ajsam, dan 'alam insan.

\section{Keterangan}

Naskah ini tidak disebut judulnya, oleh karena membahas tentang istilah-istilah dalam tasawuf yang diungkapkan dalam bahasa Aceh. Ukuran naskah ini seperti notebook yang memanjang, hal tersebut mengingat teks ditulis dalam bentuk nazam (syair). Di beberapa halaman naskah terdapat catatan pinggir teks (matan), seperti yang terlihat pada halaman 13, yang menjelaskan beberapa istilah dalam nash. 


\section{Sair al-Salikin ila 'lbadat Rabb al-'Alamin}

$\begin{array}{cccc}\text { 00/TS/HF-01/2012 } & \text { Jawi } & \text { Prosa } & 594 \mathrm{hlm} \\ \text { Kertas Eropa } & 16,5 \times 22 \mathrm{~cm} & 15.5 \times 10.5 \mathrm{~cm} & 20,21 \mathrm{baris} / \mathrm{hlm}\end{array}$

\section{Pengarang}

'Abd as-Shamad al-Jawi al-Palimbani

\section{Penulisan}

Selesai ditulis di Mekkah pada awal tahun 1194 H (1780 M). Penanggalan ini sesungguhnya terdapat pada bagian akhir teks Kitab Sair al-Salikin oleh pengarang sendiri 'Abd as-Shamad al-Jawi al-Palimbani.

Selesai disalin kitab ini oleh Haji Abd Hamid di Mekkah, hari Ahad pada bulan Zulqa'dah.

\section{Kolofon}

\section{Cap Kertas}

$\mathrm{AM}+7$ chineline

\section{Gambaran Isi}

Sebagaimana biasanya karya klasik ulama nusantara terdahulu, kandungan ini kitabnya interdisipliner ilmu, karena itu pada dasarnya naskah Sair al-Salikin dapat dikategorikan ke tasawuf, ibadah dan akhlak. Pembahasan masalah-masalah fiqih dan ibadah dalam teks dikemukakan dalam perspektif tasawuf.

Naskah ini terdiri dari empat juz (aqsam) dan penutup, sebagaimana yang disebut oleh pengarang di awal penulisan kitabnya. Setiap juz dibagi kepada sepuluh bab, yang masing-masing bab terdiri dari beberapa pasal.

Juz yang pertama menyatakan ilmu ushuluddin, yaitu ilmu i'tikad Ahl al-Sunnah wa al-Jamaah dan yang taat. 
Juz kedua tentang adab, yaitu hukum adab (kesopanan) yang berlaku, seperti makan, minum, kawin, usaha kehidupan di dunia, halal dan haram, bersahabat dan uzlah. Juz ketiga tentang kecelaan, dan Juz yang terakhir munjiyat, yaitu melepaskan (menjauhi) diri dari apa yang dapat membinasakan agama.

\section{Keterangan}

Naskah ini milik koleksi pribadi masyarakat Aceh, Hafas Furqani di Lingke Banda Aceh, yang diwarisi oleh keluarganya. Naskah ini tidak lengkap, halaman awal dan akhir tidak ada. Kondisi naskah masih baik dan mudah terbaca, pinggiran kertas juga masih kuat dan tidak terdapat lembaran bolong-bolong atau robek di tengah halaman. Namun, naskah terlepas dari jilid bundelan, hanya sebagian terikat dengan beberapa kuras dari benang, di antara kuras ada halaman kertas yang hilang (kim). 


\section{Bidayat al-Hidayah}

00/TS/MNA-458/2012

$\begin{array}{ccc}\text { Jawi } & \text { Prosa } & 192 \mathrm{hlm} \\ 22 \times 16 \mathrm{~cm} & 14 \times 8,5 \mathrm{~cm} & 15 \text { baris } / \mathrm{hlm}\end{array}$

\section{Pengarang}

Muhammad Zain al-Faqih Jalal al-Din al-Syafi'i al-Asyi

\section{Penulisan}

\section{Kolofon}

Tammat al-kitab al-musamma Bidayat al-Hidayah pada hari Khamis pada waktu Dzuhur pada negeri Samalanga wa-katibuhu Leubee 'Abd al-Shamad negeri Fathani, ibu bapaknya asal mengarang Kitab ini Syeikh Muhammad al-Zain anak Tuan Faqih Jalaluddin pada negeri Makkah, bermazhab Imam Syafi'i. Amin.

\section{Cap Kertas}

Bulan Sabit Tersenyum dalam Perisai

\section{Gambaran Isi}

Kandungan ini naskah Mawa'id al-Badi'ah telah diuraikan di atas. Sebagaimana disebutkan, bahwa naskah ini konsis terhadap permasalahan teologi dan filosofi (tasawuf). Naskah ini menjelaskan tentang wajib syara', wajib naqli, dan wajib aqli. Di dalamnya juga disebutkan hukum belajar ilmu ushuluddin, syarat, wajib, sunat, mubah, haram, mustahil. Selanjutnya, membahas sifat 20 dan dalil-dalil dari Al-Qur'an, nama-nama nabi, kitab, dan shuhuf yang diberikan kepada nabi dan rasul.

Termasuk penyebutan akan ulama-ulama tasawuf yang berada di luar akidah, disebutkan "Bermula dikeluarkan daripada ulama yang dahulu itu tiga orang, yaitu Hamzah Fansuri dan Syamsuddin Sumatrani dan Saifurrijal, karena orang yang tiga ini sudah 
disalahkan oleh segala ulama di Aceh, dan kitab mereka sudah ditunu melainkan yang sudah disembunyi oleh setengah orang".

\section{Keterangan}

Sampul naskah dari kain warna coklat tua, sudah dimakan rayap di bagian atas. Hampir semua halaman naskah dipenuhi dengan keterangan syarah yang ditulis sekitar matan teks.

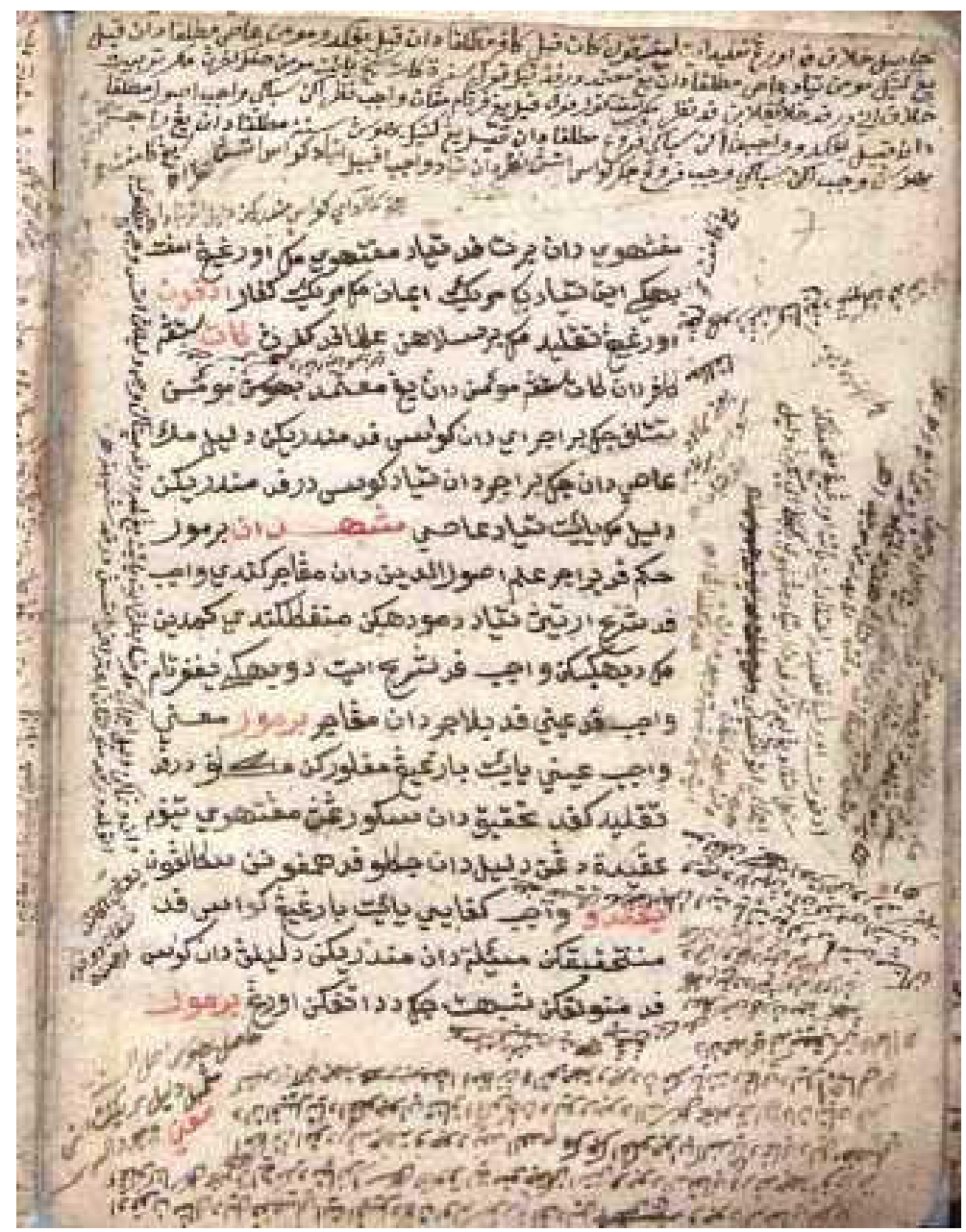

Halaman Naskah Bidayat al-Hidayah 


\section{Bidayat al-Hidayah}

00/TS/TAM-84/2012

Jawi

Prosa

$160 \mathrm{hlm}$

Kertas Eropa

$21 \times 15.5 \mathrm{~cm}$

$14 \times 10 \mathrm{~cm}$

17 baris/hlm

\section{Pengarang}

Muhammad Zain al-Faqih Jalal al-Din al-Syafi'i al-Asyi

\section{Penulisan}

\section{Kolofon}

\section{Cap Kertas}

Bulan Sabit Tersenyum dalam Perisai

\section{Gambaran Isi}

Naskah ini menjelaskan tentang wajib syara', wajib naqli, dan wajib aqli. Di dalamnya juga disebutkan hukum belajar ilmu ushuluddin, syarat, wajib, sunat, mubah, haram, mustahil. Selanjutnya, membahas sifat 20 dan dalil-dalil dari Al-Qur'an, nama-nama nabi, kitab, dan shuhufyang diberikan kepada nabi dan rasul. Selanjutnya, pengarang kitab menyebutkan ulama-ulama tasawuf yang berada di luar jalur akidah, di antaranya Hamzah Fansuri, Syamsuddin asSumatrani, dan Saifurrijal.

\section{Keterangan}

Naskah ini lengkap, walaupun terdapat kerusakan akibat serangga/ rayap dan juga akibat air, namun masih terbaca teks.

Teks naskah ditulis dalam aksara Arab Jawi menggunakan tinta hitam dan rubrikasi merah. 


\section{Tafrahat al-Dzakirin}

00/TS/MNA-271/2012

Kertas Eropa
Jawi

Prosa

$23 \times 17 \mathrm{~cm}$

$15 \times 10 \mathrm{~cm}$

$28 \mathrm{hlm}$

$21 \mathrm{baris} / \mathrm{hlm}$

\section{Pengarang}

\section{Penulisan}

2 Rabi'al-Awwal 1283 H [15 Juli 1866 M]

\section{Kolofon}

\section{Cap Kertas}

Bulan Sabit Bersusun Tiga, Tahun 1823

\section{Gambaran Isi}

Sesuai kandungan isi naskah, bahwa pengarng kitab mengajak seluruh salik untuk dapat mendekatkan diri kepada Allah. Naskah ini menguraikan zikir dari berbagai sisi berdasarkan ayat Al-Qur'an dan hadis Nabi, adab dan sikap dalam berzikir, doa-doa yang dibacakan dan kelebihan-kelebihan zikir.

\section{Keterangan}

Catatan di halaman depan naskah tertulis "dan empunya kitab ini ...", tidak terbaca karena sudah dicoret dan dihilangkan nama tersebut. Naskah ini tidak lengkap di halaman akhir, karena ada bagian yang hilang, sehingga kandungan isinya bersambung kepada hikayat Nabi Sulaiman. 


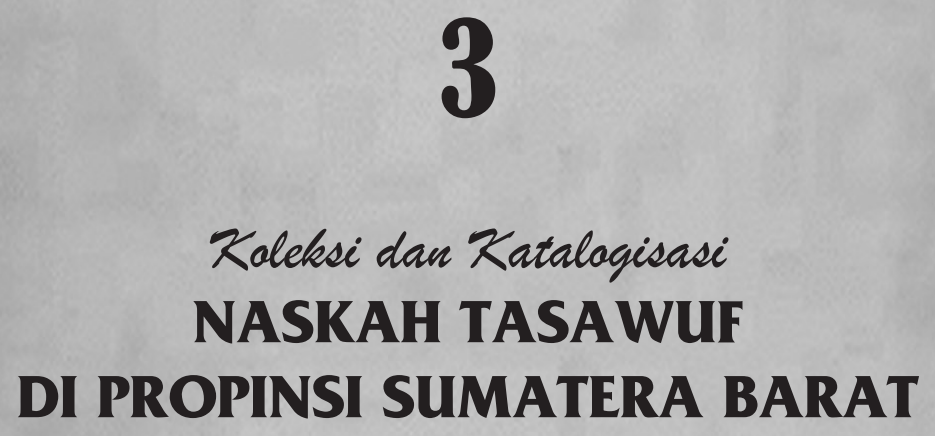

Oleh:

Zulkarnain Yani

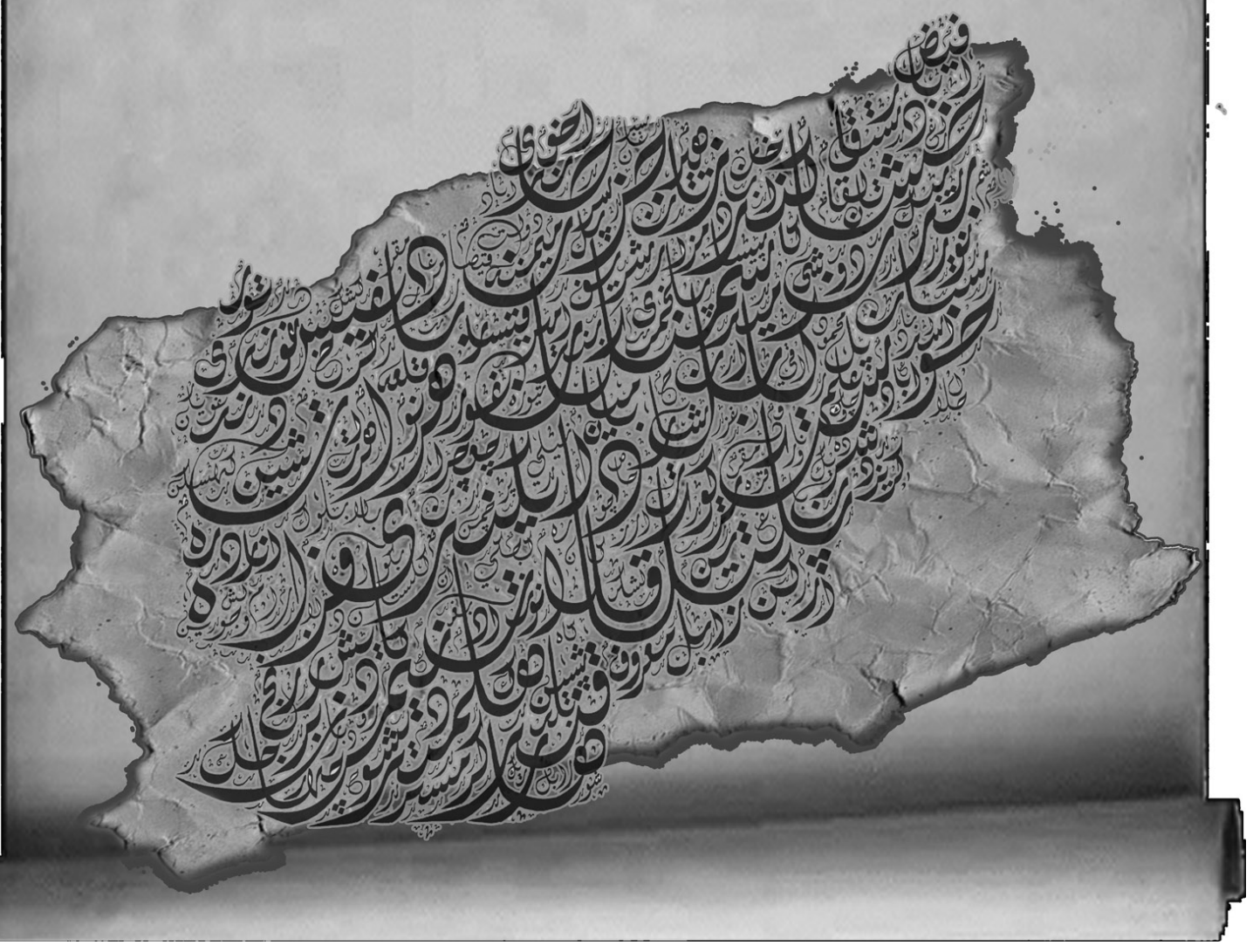




\title{
Koleksi Suluah Community
}

\author{
Al-Du'aiyyah al-Khatm al-Khawajakaniyyah \\ al-Naqsyabandiyyah \\ MS.TS/SC/PDG/01 \\ Kertas Eropa \\ Arab - Melayu \\ $18,2 \times 24,5 \mathrm{~cm}$ \\ Prosa \\ $9,1 \times 16,6 \mathrm{~cm}$ \\ $21 \mathrm{hlm}$ \\ 5 baris $/ \mathrm{hlm}$
}

\section{Asal Naskah}

Surau Tuanku Mudik Tampang Rao

\section{Pengarang/Penyalin}

Syeikh Nuruddin an-Naqsyabandi Rao

\section{Kolofon:}

Hadza milk al-faqir ar-Raji ila 'afuwwi rabbihil qadir Syeikh Ahmad Nuruddin an-Naqsyabandi ar-Rawi

\section{Gambaran Isi}

Naskah ini berisi tentang doa khatam khawajakan yang dikarang oleh Imam Rabbani Syeikh Ahmad as-Sirhindi, yang disalin oleh Syeikh Ahmad Nuruddin an-Naqsyabandi. Doa khatam khawajakan ini adalah salah satu amalan dalam Suluk Tarekat Naqsyabandiyah yang dilakukan setelah seorang salik melakukan pembai'atan. Prosesi mengamalkan doa ini mesti dipimpin oleh Syeikh mursyid atau badal-nya dalam ruangan tertutup. Sebagai sebuah amalan sakral dalam Tarekat Naqsyabandiyah, pengamalan amalan ini tertutup bagi khalayak umum.

Doa ini berisi tawassul terhadap Ahli Tarekat Mu'tabarah, seperti an-Naqsyabandiyah, as-Suhruwardi, al-Qadiriyah, dan lainnya.

\section{Gambaran Lain}

Naskah ini dalam keadaan baik dan lengkap. Memakai tinta hitam tanpa rubrikasi. Penulisan teks khatam khawajakan ini disertai dengan terjemahan gantung dalam bahasa melayu. 


\section{Risalah pada Menyatakan Peri Ma'rifat Kita kepada Allah}

$\begin{array}{cccc}\text { MS.TS/SC/PDG/02 } & \text { Arab - Melayu } & \text { Prosa } & 19 \mathrm{hlm} \\ \text { Kertas Lokal } & 16,7 \times 22,5 \mathrm{~cm} & 10 \times 15 \mathrm{~cm} & 18 \mathrm{baris} / \mathrm{h} / \mathrm{m}\end{array}$

\section{Asal Naskah}

Surau Tuanku Mudik Tampang Rao

\section{Pengarang/Penyalin}

[anonim]

\section{Gambaran Isi}

Naskah ini berisi tentang ilmu tasawuf yang tergolong kepada tasawuf muntahi (tingkat tinggi) karena pembahasan mencakup pengertian yang halus-halus dalam ilmu tasawuf, mencakup pengertian diri, wujud, teori martabat nur, asal penciptaan, dan relevansinya dengan diri insan kamil. Pembahsan dalam teks ini dimulai dengan mengutip sebuah hadis mauquf yang sangat populer di kalangan tasawuf, yaitu hadis:

$$
\text { من عرف نفسه فقد عرو ربه }
$$

Pada permulaan teks disebutkan penjelasan sebagai berikut:

Alhamdulillah was shalatu was salamu 'ala man la nabiyya ba'dahu. Adapun kemudian dari itu, maka ini risalah menyatakan peri ma'rifat kita akan Allah dan Rasulullah dan akan diri kita ini dengan jalan yang betul seperti yang tersebut dalam hadis Rasulullah man 'arafa nafsahu fagad 'arafa rabbahu. Artinya: "barangsiapa yang mengenal dirinya, bahwasanya mengenal ia akan Tuhannya" (hal 1).

\section{Gambaran Lain}

Naskah dalam keadaan baik. Tulisan menggunakan khat naskhi yang cukup rapi dan mudah dibaca. Teks menggunakan tinta hitam tanpa rubrikasi. Pada bagian-bagian tertentu teks, terdapat tinta yang telah mengembang akibat pengaruh cuaca. 


\section{Kifayat al-Muhtajin al-Masyrab ila \\ al-Muwahhiddin bi al-Wahdat al-Wujud}

$\begin{array}{cccc}\text { MS.TS/SC/PDG/03 } & \text { Arab - Melayu } & \text { Prosa } & 20 \mathrm{hlm} \\ \text { Kertas Eropa } & 19,5 \times 26,8 \mathrm{~cm} & 11,2 \times 18,8 \mathrm{~cm} & 15 \text { baris } / \mathrm{hlm}\end{array}$

\section{Asal Naskah}

Surau Tuanku Syeikh Batuhampar

\section{Pengarang/Penyalin}

Syeikh 'Abd al-Ra'uf al-Fansuri

\section{Gambaran Isi}

Sebagaimana tertera pada judulnya, naskah ini berisi tentang pembahasan mengenai tasawuf muntahi yang bekaitan dengan paham wahdatul wujud. Pembahan di dalamnya juga mencakup tentang martabat tanazzul, yaitu yang dikenal dengan martabat tujuh.

\section{Gambaran Lain}

Teks dalam keadaan baik dan lengkap. Tinta yang digunakan berwarna hitam dengan rubrikasi. Khat yang dipakai yaitu khat naskhi yang tidak begitu rapi, namun dapat dibaca dengan jelas. Asal naskah, yaitu hadiah dari seseorang di Tanjuang Barulah Tanah Datar, yang diperolehnya dari orang Bukittinggi, yang kemudian dihibahkan kepada Buya Batuhampar dengan harapan dapat dijaga dengan baik. 


\section{Risalah Lubuak Ipuah}

$\begin{array}{cccc}\text { MS.TS/SC/PDG/04 } & \text { Arab - Melayu } & \text { Prosa } & 64 \mathrm{hlm} \\ \text { Kertas Lokal } & 16 \times 21 \mathrm{~cm} & 12,5 \times 17,4 \mathrm{~cm} & \end{array}$

\section{Asal Naskah}

Surau Buya Mansuruddin Tuanku Bagindo Lubuak Ipuah

\section{Pengarang/Penyalin}

Syeikh Abdurrahman Lubuak Ipuah

\section{Gambaran Isi}

Naskah berisi tentang tuntunan ibadah sehari-hari, kemudian dilanjutkan dengan pembahasan tauhid yang berakhir dengan penjelasan tasawuf yang cukup mendalam. Pembahasan tasawuf yang disebutkan berkaitan dengan konsep Nur Muhammad, kemudian hubungan sifat dua puluh, terutama sifat maknawiyyah terhadap tubuh manusia. Pada awal risalah ini terdapat sebuah ilustrasi yang merupakan terompah Nabi Muhammad yang berbentuk segi tiga dengan tulisan ayat-ayat, di antaranya bertuliskan khatamun nubuwwah. Menurut penjelasannya pencantuman khatam nubuwwah ini mempunyai faedah yang besar.

\section{Gambaran Lain}

Naskah dalam kondisi baik. Teks menggunkan tinta berwarna biru tanpa rubrikasi. Teks ditulis dengan khat naskhi yang cukup rapi, sehingga dapat dibaca dengan baik. Informasi bahwa naskah ini merupakan hasil permusyawaratan antara alim ulama dengan pemangku adat di Lubuak Ipuah, berasal dari Abdurrasyid Tuanku Kadhi Lubuak Ipuah. 


\section{Jawab al-Musykilat}

MS.TS/SC/PDG/05

Kertas Lokal

\author{
Arab \\ Prosa
}

$17 \times 23,5 \mathrm{~cm}$
$10 \times 15 \mathrm{~cm}$
$92 \mathrm{hlm}$

$17 \mathrm{baris} / \mathrm{hlm}$

\section{Asal Naskah}

Surau Sungai Buluah

\section{Pengarang/Penyalin}

'Abd al-Rahman Bawan al-Syafi'i al-Asy'ary al-Syathari

\section{Kolofon:}

Maka inilah perkara yang sebelas perkara serta dengan segala jawabnya, wabillahi at-taufiq wa shallallah 'alaihi sayyidina Muhammadin wa alihi wa shahbihi wa sallama, ghafarallah lahu wa walidaihi wa li ahli baitihi wa li jami'il muslimin amin ya Rabbal 'alamin, dan adalah selesai daripada mengarang kitab ini pada pada tahun "ba", pada bulan Syawal, pada malam Jum'at, pada waktu Isya.

\section{Gambaran Isi}

Naskah ini, sebagai yang tertera pada teksnya menguraikan sebelas pertanyaan mengenai ajaran tasawuf yang tergolong dalam tasawuf muntahi. Dalam mukaddimah risalah ini, disebutkan secara gamblang mengenai penulis berikut sebab penulisan teks ini:

Amma ba'du Adapun kemudian daripada itu maka datanglah soal kepada faqir yang dha'if, yaitu Abdurrahman, Bawan nama negerinya, Syafi'i nama mazhabnya, i'tikad Asy'ari nama i'tikadnya, Syatthary nama tarekatnya, dan adalah banyak masalah itu sebelas perkara, maka diberi jawab satu masalah kemudian daripada satu masalah, dan aku namai kitab ini Jawab al-Musykilat...

Kemudian, sipenulis masuk kepada lafaz pertanyaan, Ialu dijawab dengan terang dan mendalam. Pertanyaan-pertanyaan yang dilontarkan, berkaitan dengan tasawuf tingkat muntahi, seperti pertanyaan mengenai wujud, dan makna filosofis kata-kata sufi. Di antara pertanyaan yang muncul: 
Masalah pertama, innallaha nafsuna wa wujuduna, wa kun[na] nafsuhu wa wujuduhu, artinya bahwasanya Allah Ta'ala itu diri kami dan wujud kami, dan kami diri dan wujudnya, adakah sah kata ini pada orang sufi atau tiada. Jawab, bahwasanya tiada harus kata ini pada orang sufi.

\section{Gambaran Lain}

Naskah dalam keadaan baik dan lengkap. Teks menggunakan khat naskhi yang cukup rapi, sehingga dapat dibaca dengan mudah. Tinta yang digunakan berwarna hitam dengan rubrikasi. 


\section{'Umdat al-Ansab}

MS.TS/SC/PDG/06

Kertas Eropa

\section{Asal Naskah}

Surau Sungai Buluah

\section{Pengarang/Penyalin}

Anonim

\section{Kolofon:}

Telah tamatlah dijadikan risalah yang dinamai "Umdat al-Ansab" ini, padahal adalah dipilih segala perkataan ini dan adalah risalah ini dipindahkan Arab-nya dari kitab bahasa Persi "Raudhatul Ahbab" dengan tolong Tuhan Malikul Wahhab, pada hari arba'a, delapan hari bulan Rajab, pada Hijrah seribu tujuh puluh sembilan tahun, karena menjunjung titah hadrat Tuan kami yang mengumpulkan segala pekerjaan kami, yaitu paduka ... Sultan Tajul Alam Shafiyatuddin Syah berdaulah, Zhillullah fil 'alam...

\section{Gambaran Isi}

Naskah ini menguraikan tentang silsilah Nabi Muhammad shallallahu 'alaihi wa sallam, menurut gambaran yang dipegang oleh Tarekat Syattariyah. Sebagai sebuah genealogi, naskah ini termasuk runtun dan komplit, karena menjelaskan sejarah dan silsilah secara akurat dan panjang lebar.

\section{Gambaran Lain}

Naskah dalam keadaan baik, namun beberapa bagian di depan halaman sudah hilang, sehingga nama pengarang yang biasa terletak pada mukaddimah tidak bisa diketahui. Naskah menggunakan khat riq'ah yang cukup rapi dan mudah dibaca. Tinta yang digunakan berwarna hitam dengan rubrikasi. Naskah genealogi ini merupakan pegangan kaum Syattariyah di Minangkabau. 


\section{Bad'u al-Khalqi al-Samawaty wa al-Ardh}

$\begin{array}{cccc}\text { MS/TS/SC/PDG/07 } & \text { Arab } & \text { Prosa } & 26 \text { baris } / \mathrm{hlm} \\ \text { Kertas Eropa } & 15,4 \times 23,4 \mathrm{~cm} & 10,5 \times 17,7 \mathrm{~cm} & -\end{array}$

\section{Asal Naskah}

Padang Tarok Sicincin

\section{Pengarang/Penyalin}

Syeikh Nur al-Din al-Raniry

\section{Gambaran Penulis dan Waktu Penulisan}

Adapun kemudian dari itu maka bahwasanya faqir yang hina lagi dha'if yang harap kepada Tuhannya yang amat mengasihani Syeikh Nuruddin anak 'Ali anak Hasanji anak Muhammad Hamid ar-Raniri tempatnya dan Syafi'i mazhabnya segala sampai ia ke Bandar Aceh Darus Salam.

\section{Gambaran Isi}

Naskah ini menguraikan tentang asal muasal penciptaan makhluk. Diawali dengan riwayat penciptaan Nur Muhammad, yang menjadi porsi khusus dalam ilmu tasawuf. Dikatakan, bahwa awal penciptaan alam ini, dari semulanya tiada, ialah bermula dari penciptaan Nur Muhammad. Syeikh Nuruddin ar-Raniri menguraikan:

Pasal pada menyatakan peri kejadian Nur Muhammad shallallahu 'alaihi wa sallam dan barang yang takluk padanya. Qalan Nabiy shallallahu 'alaihi wa sallam: Kanallahu wa laa syai'un ma'ahu, artinya bersabda Nabi adalah Allah Ta'ala dan tiada sesuatu pun sertanya ...... bahwasanya Allah Ta'ala menjadikan nyawa Muhammad shallallahu 'alaihi wa sallam daripada cahaya Qudrat zat-Nya dan dijadikannya sekalian alam daripada nyawa Muhammad...

Pasal-pasal selanjutnya menguraikan masalah penciptaan alam, yang bersandar pada Nur Muhammad ini. mulai dari malaikatmalaikat, jin, awan, bintang, bumi, dan lain-lainnya. 


\section{Gambaran Lain}

Naskah dalam keadaan baik, namun beberapa halaman di belakang naskah tampak hilang. Teks menggunakan khat naskhi yang cukup rapi dan mudah dibaca. Tinta yang digunakan adalah hitam dengan rubrikasi. 


\begin{tabular}{cccc}
\multicolumn{4}{c}{ Mawahib Rabb al-Falaq al-Syarah } \\
al-Qasyidah bi al-Milaq \\
MS.TS/SC/PDG/08 & Arab & Prosa & 17 baris/hlm \\
Kertas Eropa & $15 \times 21 \mathrm{~cm}$ & $8,5 \times 14 \mathrm{~cm}$ & -
\end{tabular}

\section{Asal Naskah}

Surau Sungai Buluah

\section{Pengarang/Penyalin}

Syeikh Isma'il bin Abdullah al-Minangkabawi

\section{Kolofon:}

Wa kanal firagh min kitabatihi lailah at-Tarwiyyah fi Teluk Belanga, lailah ar-Rabu', tsaman dzil hijjah al-haram sanah 1268 bi qalam alfaqir ila maulahu al-'aliy al-kabir Isma'il bin Abdullah as-Syafi'i asSyazili an-Naqsyabandi

\section{Gambaran Isi}

Naskah ini merupakan uraian menarik mengenai tasawuf berdasarkan Tarekat Syaziliyyah dan Naqsybandiyyah. Teks awalnya merupakan bait-bait sya'ir yang ditulis oleh seorang tokoh Syaziliyyah, yaitu Syeikh Qadhi Nashiruddin ibn Bintil Milaq, kemudian matan ini dlsyarah oleh Syeikh Ibnu Alan anNaqsyabandi, seorang tokoh Naqsyabandi di Mekkah (dia terkenal dengan syarahnya yang besar mengenai al-Azkar an-Nawawiyyah). Kemudian Syeikh Ismail menguraikan syarah Ibnu Alan dalam bahasa Jawi, kemudian diberinya interpretasi menurut keilmuannya pula.

Layaknya teks-teks tasawuflain, karya ini berbicara mengenai aspekaspek akhlak. Dimulai dengan keutamaan ilmu tasawuf, keharusan belajar tasawuf melalui guru, adab kepada guru dan sebagainya. Sebagai teks yang dikomentari oleh seorang Naqsyabandi, naskah ini sarat dengan interpretasi Naqsyabandi, ketimbang Syazili. 
Bab 3: Koleksi \& Katalogisasi: Naskah Tasawuf di Propinsi Sumatera Barat

\section{Gambaran Lain}

Naskah dalam keadaan baik dan lengkap. Teks menggunakan tinta hitam tanpa rubrikasi. Khat yang digunakan naskhi yang cukup rapi sehingga mudah dibaca. 


\section{Risalah Kaifiyyat al-Thariqah al-Syadziliyah \\ MS.TS/SC/PDG/09 \\ Arab \\ Prosa \\ $11 \mathrm{baris} / \mathrm{hlm}$ \\ Kertas Eropa \\ $15,2 \times 20,7 \mathrm{~cm}$ \\ $14,5 \times 8,4 \mathrm{~cm}$}

\section{Asal Naskah}

Surau Batangkapeh, Pesisir Selatan.

\section{Pengarang/Penyalin}

Haji Muhammad Aqib Batangkapeh

\section{Gambaran Isi}

Naskah ini menguraikan tata cara pengamalan wirid-wirid dalam Tarekat Syaziliyyah. Dimulai dengan prosesi taubat dari segala dosa, kemudian ber-tawassul dengan ahli silsilah Syaziliyyah. Selanjutnya, mengamalkan bacaan-bacaan sebagai wirid harian. Pada halaman terakhir disebutkan silsilah pengambilan Tarekat Syaziliyyah ini oleh Muhammad 'Aqib dari Syeikh Abdurrahman. Pada mukaddimah naskah ini disebutkan:

Alhamdulillah was salah was salam 'ala man la nabiyya ba'dahu, amma $b a, d u$, adapun kemudian daripada itu, maka inilah risalah yang simpan peri menyatakan kaifiyyah mengamalkan Tarekat Syaziliyyah yang dibangsakan kepada Sayyidi as-Syarif Abil Hasan as-Syazili Qaddasallahu sirrahu.

\section{Gambaran Lain}

Naskah dalam kondisi baik. Terdapat beberapa teks yang mengembang akibat cuaca, namun tidak mengganggu pembacaan. Khat yang digunakan yaitu naskhi yang cukup rapi, sehingga mudah dibaca. 


\section{Bayan Tajalli}

MS.TS/SC/PDG/10

Kertas Eropa

\section{Asal Naskah}

Surau Lubuakminturun

\section{Pengarang/Penyalin}

Syeikh Abdurra'uf Singkel
Arab
Prosa
$17 \mathrm{hlm}$
$14 \times 22 \mathrm{~cm}$
$9 \times 16 \mathrm{~cm}$
$17 \mathrm{baris} / \mathrm{hlm}$

\section{Kolofon:}

Tammat kitab Bayan Tajalli pada dua puluh empat hari, bulan Rabi'ul Awal, pada hari Selasa, waktu Dzuhur jua adanya.

\section{Gambaran Isi}

Naskah ini berisi tentang penjelasan "tajalli" (kenyataan) Tuhan. Dimulai dengan ungkapan "asal i'tikad yang sempurna", artinya pemahaman yang sempurna, mencakup tauhid dan pemahaman tauhid tentang keberadaan Allah. Pada awal teks disebutkan:

Bismillahirrahmanirrahim, wahdah, was shalatu was salamu 'ala man la Nabiyya ba'dahu. Adapun kemudian dari itu maka ketahui olehmu hai Thalib, bahwasanya asal i'tikad yang sempurna, yaitu mengi'tikadkan bahwasanya Hak Ta'ala laisa kamislihi syai'un tiada sepertinya sesuatu jua dan baginya jua tiap-tiap sesuatu yakni tiada sepertinya sesuatu daripada pihak asma'-nya dan tajalli-nya, maka dengan kata itu seyogyanyalah kita i'tikadkan bahwa Hak Ta'ala itu tiada baginya rupa yang tertentu ia dengan dia, dan harus baginya tajalli dengan barang rupa yang dikehendakinya.

Setelah mukaddimah yang menyebutkan pentingnya i'tikad yang benar, kemudian dilanjutkan dengan pembahasan "martabat tajalli zat", yang disebut juga dengan martabat tujuh.

\section{Gambaran Lain}

Naskah dalam keadaan baik dan lengkap, namun terdapat banyak kesalahan dalam penyalinannya. Jenis tulisan yang digunakan adalah naskhi yang tidak begitu rapi, namun dapat dibaca dengan jelas. Tinta yang digunakan berwarna hitam tanpa rubrikasi. 


\section{Daqa'iq al-Hurf}

$\begin{array}{cccc}\text { MS.TS/SC/PDG/11 } & \text { Arab } & \text { Prosa } & 14 \mathrm{hlm} \\ \text { Kertas Eropa } & 14 \times 22 \mathrm{~cm} & 9 \times 16 \mathrm{~cm} & 11 \mathrm{baris} / \mathrm{hlm}\end{array}$

\section{Asal Naskah}

Surau Lubuak Minturun

\section{Pengarang/Penyalin}

Syeikh 'Abd al-Ra'uf al-Fansuri

\section{Gambaran Isi}

Naskah ini, sesuatu judulnya "Daqa'iqul Huruf", detail-detail huruf, berisi tentang kajian tasawuf yang cukup dalam, yaitu membahas makna simbol huruf-huruf kalimat Allah pada tubuh manusia. Ini sesuai dengan fragmen pertama karya ini, yaitu:

Inilah karangan Syeikh Abdurra'uf, kitab yang bernama Daqa'iqul Huruf, soal apa nama Allah subhanahu wa ta'ala di dalam wujud insan itu, maka jawab: adapun nama Allah Ta'ala dalam wujud itu [ialah ibarat] kelima jari, karena nama Allah empat huruf, pertama alif, dan kedua lam, dan ketiga lam akhir dan keempat $h a^{\prime}$, demikian lagi pada tubuh insan itu lima jari, adapun jari kelingking huruf alif, dan jari manis lam awwal, dan jari tengah huruf lam tsani, dan jari tunjuk dan empu tangan itu huruf ha'; dan demikian lagi dinyatakan Allah Ta'ala pada tangan kanan dan kiri, demikian pula jari kaki, seperti yang tersebut dahulu itu, karena wujud insan itu kalimah nama Allah dan nama Rasulullah, yaitu Muhammad...

Naskah itu diawali dengan ilustrasi yang penuh dengan simbolsimbol tasawuf.

\section{Gambaran Lain}

Naskah dalam keadaan baik, namun beberapa lembar naskah sudah lepas dari penjilidannya. Pada halaman awalnya terdapat banyak scolia, yang berisi mukaddimah kitab, dan makna simbolsimbol ilustrasi. Khat yang digunakan yaitu naskhi yang cukup rapi dan mudah dibaca. Tinta yang digunakan hitam dengan rubrikasi. 


\section{Silsilah Syeikh 'Abd al-Ra'uf}

$\begin{array}{cccc}\text { MS.TS/SC/PDG/12 } & \text { Arab }- \text { Melayu } & \text { Prosa } & 7 \mathrm{hlm} \\ \text { Kertas Lokal } & 14 \times 22 \mathrm{~cm} & 9 \times 16 \mathrm{~cm} & 11 \text { baris } / \mathrm{hlm}\end{array}$

\section{Asal Naskah}

Surau Lubuak Minturun

\section{Pengarang/Penyalin}

[anonim]

\section{Gambaran Isi}

Naskah ini berisi tentang riwayat perjalanan Syeikh Abdurra'uf Singkel menuntut ilmu kepada Syeikh Ahmad Qusyasi di alMadinah al-Munawwarah. Diawali dengan:

Bismillahirrahmanirrahim, alhamdulillahi rabbil 'alamin, was shalatu was salamu 'ala muhammadin khatimin Nabiyyina wa alihi wa ashhabihi kullihim ajma'in, amma ba'du. Maka berkata hamba yang faqir lagi hina, tidak ada baginya nafkah untuk menuntut ilmu. Inilah satu cerita silsilah Tuan Syeikh Abdurra'uf tatkala beliau menuntut ilmu ke negeri Madinah, kepada Syeikh Ahmad Qusyasyi. Adapun kemudian daripada itu maka inilah khabar Tuan Syeikh Abdurra'uf orang negeri singkiri Ibn 'Ali Fansuri, tatkala beliau menuntut ilmu di negeri Madinah kepada Tuan Syeikh Ahmad Qusyasyi beberapa lama masa beliau disinan sampai sembilan belas tahun (hal. 1).

Dalam riwayat ini ditonjolkan bagaimana kepatuhan Syeikh Abdurra'uf kepada gurunya Syeikh Ahmad Qusyasyi, sehingga digendongnya guru bila hendak ke surau untuk mengajar. Dikisahkan pula beberapa kekeramatan Syeikh Abdurra'uf Singkel, yang menjadi penyokong sendiri citra Syeikh tersebut.

Meski dalam mukaddimahnya diinformasikan, bahwa naskah ini berbicara mengenai riwayat Syeikh Abdurra'uf, namun juga dilengkapi dengan riwayat Syeikh Burhanuddin, salah seorang murid beliau yang utama, ketika menuntut kaji ke Aceh. Teks ini ditutup dengan penyebutan silsilah khalifah-khalifah Syeikh Burhanuddin di Ulakan tersebut. 


\section{Gambaran Lain}

Kondisi naskah dalam keadaan baik dan lengkap. Jenis khat yang digunakan yaitu naskhi yang cukup rapi. Warna tinta dalam naskah ini, yaitu hitam dengan rubrikasi. 


\section{Syarah Aja'ib al-Qalb}

MS.TS/SC/PDG/13

$$
\text { Arab }
$$

Prosa

$73 \mathrm{hlm}$

Kertas Eropa

$16,5 \times 21 \mathrm{~cm}$

$9,3 \times 13,8 \mathrm{~cm}$

$11 \mathrm{baris} / \mathrm{hlm}$

\section{Asal Naskah}

Padang Tarok Sicincin

\section{Pengarang/Penyalin}

Hujjatul Islam Imam Abu Hamid al-Ghadzali

\section{Gambaran Isi}

Naskah ini berisi mengenai penjelasan mengenai masalah hati, mulai dari defenisi hati, pengertian ruh dan akal serta perbedaannya dengan hati, kemudian diuraikan cara-cara membersihkan hati dari sifat-sifat tercela. Secara implisit, kandungan naskah ini disebutkan dalam mukaddimah, yaitu terdiri 14 bahasan: makna jiwa, ruh, dan akal, perjelasan mengenai tentara-tentara hati, kekhususan hati manusia, penjelasan mengenai sifat-sifat tercela yang terdapat dalam hati manusia, keadaan hati bila dihubungkan dengan ilmu pengetahuan, klasifikasi ilmu-ilmu yang menghiasi hati manusia, perbedaan antara ilham dan ilmu, perbedaan metode pencapaian ilmu antara orang-orang sufi dengan para ulama, nash-nash yang menjelaskan keshahan jalan ahli sufi, menjelaskan penguasaan hati oleh syaitan dan hal-hal yang menolong hati manusia.

\section{Gambaran Lain}

Naskah ini ialah satu juzu' (bagian) dari kitab lhya' Ulumuddin karya monumental Imam al-Ghazali, yaitu juzu' ketiga dari empat rubu'. Naskah dalam keadaan baik, lengkap. Tulisannya yang merupakan khat naskhi dapat dibaca dengan baik, meski kurang begitu rapi. Terdapat beberapa kesalahan penyalin, seperti titik (nuthqah) yang ketinggalan. 


\section{Nadzam al-Miqat al-Ahmadiyyah fi Suluk}

al-Thariq 'Aliyyah al-Naqsyabandiyyah

$\begin{array}{cccc}\text { MS.TS/SC/PDG/14 } & \text { Arab } & \text { Prosa } & 11 \text { baris } / \mathrm{hlm} \\ \text { Kertas Eropa } & 15,2 \times 20,7 \mathrm{~cm} & 14,5 \times 8,4 \mathrm{~cm} & -\end{array}$

\section{Asal Naskah}

Surau Tuanku Mudik Tampang Rao

\section{Pengarang/Penyalin}

[anonim]

\section{Gambaran Isi}

Naskah ini tediri dari nazham, berupa sya'ir Arab namun penyusunannya tidak menggunakan khayal imajinasi. Pada pragraf awal teks ini disebutkan bahwa nazham ini seyogyanya dihafal dan dilantunkan oleh seorang salik dalam Tarekat Naqsyabandiyah, sebagai sebuah wirid harian. Bila tinjau dari isinya, teks berisi tentang Isyarat-Isyarat keunggulan Tarekat Naqsyabandiyah. Salah satu bait yang terdapat fragmen tersebut adalah:

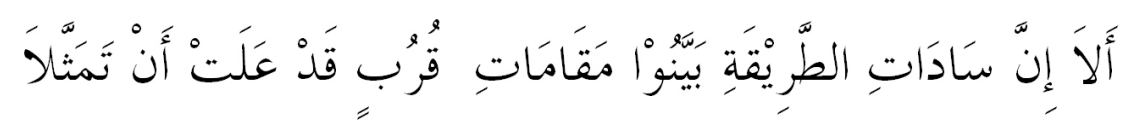

Ketahuilah olehmu, bahwasanya segala tuan-tuan ahli Tharikat itu telah dinyatakan mereka akan beberapa maqam kehampiran, begitu sangat tinggi bila dimisalkan.

Teks ini ditutup dengan beberapa bait mengenai pusaran-pusaran zikir pada tubuh manusia, yang disebut dengan istilah Da'iratul Imkan.

\section{Gambaran Lain}

Teks nazhm ini diberi terjemahan gantung dalam bahasa Melayu di bawah tiap-tiap baitnya, sehingga memudahkan pembacaan serta pemahaman terhadapnya. Teks ini dalam kondisi baik. Tulisan naskhi yang digunakan cukup rapi, terang dan mudah dibaca. Tinta 
Bab 3: Koleksi \& Katalogisasi: Naskah Tasawuf di Propinsi Sumatera Barat

yang digunakan berwarna hitam, tanpa rubrikasi. Sebagai sebuah teks salinan, naskah ini mempunyai banyak kesalahan, pemberian harakat misalnya. 


\section{Syair Perahu Hamzah Fansuri}

$\begin{array}{cccc}\text { MS.TS/SC/PDG/15 } & \text { Arab - Melayu } & \text { Prosa } & 13 \mathrm{hlm} \\ \text { Kertas Eropa } & 10,3 \times 16,2 \mathrm{~cm} & 5,0 \times 11,5 \mathrm{~cm} & 9 \mathrm{baris} / \mathrm{h} / \mathrm{m}\end{array}$

\section{Asal Naskah}

Simpang Tonang, Pasaman Barat.

\section{Pengarang/Penyalin}

Syeikh Hamzah Fansuri

\section{Gambaran Isi}

Naskah ini berisi sya'ir-sya'ir bertema tasawuf dengan memakai alegoris yang menawan. Hamzah dalam sya'ir ini mengibaratkan manusia itu sebuah perahu. Ketika sebuah perahu akan berlayar di lautan luas, lepas, maka terlebih dahulu perlu diperiksa segala bekal, berikut kondisi perahu, alat dan sauh, kondisi layar dan sebagainya. Begitu pula manusia dalam mengharungi hidup mesti melengkapi bekal, terutama ilmu dan amal. Supaya selamat sampai ke pulau tujuan, yaitu negeri akhirat.

Di antara pembuka sya'ir ini adalah:

Bismillah pertama dibaca

Alhamdulillah puji yang nyata

Berkat Muhammad penghulu kita

Wajiblah kita mengikut dia

Karangan ini suatu madah

Mengarangkan sya'ir terlalu indah

Membetuli jalan tempat berpindah

Di sanalah i'tikad diperbetuli sudah

Wahai muda kenali dirimu

Ialah perahu tamsil tubuhmu

Tiadalah berapa lama hidupmu

Ke akhirat jua tempat diammu

Wahai muda 'arif budiman

Hasilkan kemudi dan pedoman

Halat perahu juga kerjakan

Itulah jalan membetuli insan 
Bab 3: Koleksi \& Katalogisasi: Naskah Tasawuf di Propinsi Sumatera Barat

\section{Gambaran Lain}

Naskah ini masih dalam kondisi baik dan utuh dari segi kertas dan teksnya. Naskah ditulis dengan menggunakan tinta hitam tanpa rubrikasi dan skolia. 


\section{Al-Thriqat al-Naqsyabandiyyah Syeikh Mahmud Pinti Kayu}

$\begin{array}{cccc}\text { MS.TS/SC/PDG/16 } & \text { Arab } & \text { Prosa } & 21 \mathrm{hlm} \\ \text { Kertas Lokal } & 16 \times 21 \mathrm{~cm} & 12,5 \times 18 \mathrm{~cm} & 11 \mathrm{baris} / \mathrm{hlm}\end{array}$

\section{Asal Naskah}

Surau Pintikayu, Solok Selatan

\section{Pengarang/Penyalin}

Syeikh Mahmud bin Abdullatif Pintikayu

\section{Kolofon:}

Walhamdulillahi rabbil 'alamin, Syeikh Mahmud al-Khalidi anNaqsyabandi al-Qa'im maqama syeikhihi abihi fi balad Pintikayu ibnu al-Marhum Syeikh Abdullathif 'afa 'anhuma.

\section{Gambaran Isi}

Naskah ini berisi dua bahasan pokok mengenai Tarekat Naqsyabandiyah. Pertama, berisi mengenai kaifiyyah mengamalkan Tarekat Naqsyabandiyah. Kedua, mengenai silsilah Tarekat Naqsyabandiyah. Di antara fragmen isi dalam naskah ini yaitu:

Inilah kaifiyyat jalan mengamalkan zikrullah pada Tarekat Naqsyabandiyah. Apabila kita telah selesai kita daripada bersuci segala anggota daripada hadast dan najis, gadang dan kecil, dan mandi taubat, serta wudhu' yang samparono, maka masuk dalam halaqah zikir...

Selain itu, didalamnya juga terdapat nasihat-nasihat terhadap seorang salik yang telah mendapat ijazah.

\section{Gambaran Lain}

Naskah ini dalam kondisi baik dan bagus, teksnya masih utuh dan tulisannya pun masih dapat dibaca dengan baik. Pada akhir naskah terdapat mahor sang Syeikh sebagai legalitas sebuah ijazah. 


\section{Syair Johan Syah Berdaulat (Pengajian Wahdatul Wujud)}

$\begin{array}{cccc}\text { MS.TS/SC/PDG/17 } & \text { Arab } & \text { Prosa } & 15 \mathrm{hlm} \\ \text { Kertas Eropa } & 10,3 \times 16,2 \mathrm{~cm} & 5,9 \times 11,5 \mathrm{~cm} & 9 \text { baris } / \mathrm{hlm}\end{array}$

\section{Asal Naskah}

Surau Simpangtonang (Pandeka Duo Koto)

\section{Pengarang/Penyalin}

[anonim][dari teks lain disebutkan ditulis oleh Syeikh Tolang Babungo]

\section{Gambaran Isi}

Teks berupa sya'ir yang cukup indah ini berisi tentang kajian mendalam mengenai Wahdatul Wujud. Dibingkai dengan perumpamaan-perumpamaan yang mudah dicerna. Misalnya, ketika ia mengumpamakan Khaliq dan makhluk, diumpamakan seperti kapas dan kain. Di antara bagian bait sya'ir ini adalah:

Johan perkasa Syah alam

Menentang qaba qausain pada siang dan malam

Ke bahrul alam senantiasa ia menyelam

'arif bijaksana zuqnya dalam

Tuanku daulat sultan indah bangsawan

Beroleh khilafah daripada Tuanku Paninjauan

Masyhur terbilang lagi pahlawan

Kepada ma'ar ma'rifat juga ia tertawan

Dalam sya'ir ini, pengarang menggunakan istilah-istilah yang familiar dalam ranah tasawuf falsafi. Hal ini tentu membuktikan bahwa isi naskah ini begitu pelik.

\section{Gambaran Lain}

Naskah ini masih dalam kondisi baik dan bagus, tidak terdapat kerusakan pada teks nya. Naskah ditulis menggunakan tinta hitam tanpa rubrikasi dan skolia. 


\section{Naskah Martabat Tubuah (Pengajian Tubuh)}

$\begin{array}{cccc}\text { MS.TS/SC/PDG/18 } & \text { Arab }- \text { Arab } & \text { Prosa } & 21 \mathrm{HIm} \\ \text { Kertas lokal } & 16 \times 21 \mathrm{~cm} & - & - \text { Baris } / \mathrm{hlm}\end{array}$

\section{Asal Naskah}

Surau Datuak Tambijo, Sungaipagu

\section{Pengarang/Penyalin}

Muhammad Ridhwan Dt. Tanbijo

\section{Gambaran Isi}

Naskah ini berbicara mengenai asal usul kejadian manusia dari anasir (unsur-unsur) yang empat, yang bermuara kepada martabat tujuh. Pada awalnya diterangkan mengenai awal penciptaan makhluk dari Nur Muhammad, kemudian dibahas mengenai pertalian insan dengan Nur Muhammad, dengan menjelaskan unsur-unsur penciptaan manusia itu sendiri. Terakhir, pembahasan ini ditutup dengan beberapa Isyarat mengenai $a^{\prime} y a n$ tsabitah dan a'yan kharjiyah, serta insan kamil.

\section{Gambaran Lain}

Naskah ini masih dalam keadaan baik dan bagus, naskah ditulis dengan tinta hitam dan bentuk teks yang tidak tersusun rapi menurut bentuk vertikal dan horizontal seperti naskah pada umumnya, tidak terdapat skolia dan rubrikasi pada naskah. 


\section{Risalah Nur Muhammad}

$\begin{array}{cccc}\text { MS.TS/SC/PDG/19 } & \text { Arab } & \text { Prosa } & 19 \mathrm{hlm} \\ \text { Kertas lokal } & 16 \times 21 \mathrm{~cm} & -\mathrm{x}- & \text { Baris } / \mathrm{hlm}\end{array}$

\section{Asal Naskah}

Surau Datuak Tambijo, Sungaipagu

\section{Pengarang/Penyalin}

Muhammad Ridhwan Dt. Tanbijo

\section{Gambaran Isi}

Tak berbeda dengan naskah-naskah pengajian tubuh lainnya, naskah ini membahas permasalahan Nur Muhammad yang menjadi pondasi pengajian tubuh. Diriwayatkan kepada alun babalun, makhluk belum ada satu pun, yang ada hanya zatul bauhti, yaitu Allah, dari situ terpancar Nur Muhammad yang menjadi cikal bakal segala makhluk.

Naskah ini juga dilengkapi dengan ilustrasi berupa lafaz laa ilaaha ilallah disertai dengan penjelasan perceraiannya dengan Nur Muhammad. Disini terdapat istilah-istilah teknis dalam pengajian tubuh, seperti nur, rohani, jasmani, martabat tujuh, insan kamil , dan lain-lainnya.

\section{Gambaran Lain}

Naskah masih dalam keadaan bagus dan baik, terdapat ilustrasi tentang pecahan kalimat laa ilaha illa Allah pada naskah ini. Naskah ditulis menggunakan tinta hitam dan biru dengan rubrikasi. 


\begin{tabular}{cccc}
\multicolumn{4}{c}{ Risalah pada Menyebutkan Mati } \\
(Terjemahan Mukasyifatul Qulub) \\
MS.TS/SC/PDG/20 & Arab & Prosa & $26 \mathrm{hlm}$ \\
Kertas Eropa & $16,2 \times 21,3 \mathrm{~cm}$ & $-\mathrm{x}-$ & $35 \mathrm{Baris} / \mathrm{hlm}$
\end{tabular}

\section{Asal Naskah}

Surau Datuak Tambijo

\section{Pengarang/Penyalin}

Muhammad Ridhwan Dt. Tambijo

\section{Gambaran Isi}

Sebagai tertera pada judul, yaitu membahas perkara hati, jelas naskah ini tasawuforiented. Berdasarkan tatanan isi teks dan sebuah cacatan pinggir, naskah ini merupakan terjemahan dari sebuah karya besar Imam al-Ghazali, yaitu mukasyifatul qulub, membuka rahasia terselubung hati.

Karya ini membahas mengenai rahasia-rahasia hati, mencakup hakikat hati, keadaan hati bila dihubungkan dengan ilmu-ilmu pengetahuan, penyakit-penyakit hati dan obatnya, dan lainnya.

\section{Gambaran Lain}

Naskah masih dalam keadaan bagus dan baik, teksnya masih dapat dibaca dengan baik. Teks naskah ditulis dengan ukuran kecil. 


\section{Tuhfah al-Ahbab Menyatakan Asal I'tikad yang Sempurna dan Menyatakan Segala Martabat Wujud}

$\begin{array}{cccc}\text { MS.TS/SC/PDG/21 } & \text { Arab } & \text { Prosa } & 21 \mathrm{hlm} \\ \text { Kertas Eropa } & 17 \times 23,5 \mathrm{~cm} & 10 \times 15 \mathrm{~cm} & 32 \text { Baris } / \mathrm{hlm}\end{array}$

\section{Asal Naskah}

Sicincin

\section{Pengarang/Penyalin}

Syeikh Abdurrahman Bawan as-Syathari

\section{Gambaran Isi}

Kitab ini merupakan sebuah kitab yang membahas tentang martabat tujuh yang mempelajari tentang martabat wujud Allah ini semua adalah pengajian khas Tarekat Syathariyah dan merupakan ajaran bagi penganut Tarekat syathariyah, semua ini dikatakan oleh penulisnya: adapun kemudian daripada itu berkata faqir yang dha'if Abdurrahman namanya, bawan nama negrinya Syafi'i nama mazhab asy'ari nama i'tikad Ayatari nama tarekatnya, sztu telah meminta kepada aku setengah dari pada sahabatku akan... kubuat suatu risalah yang semampunya dengan bahasa Jawi dengan pada asal menyatakan i'tikad yang sempurna dan menyatakan segala martabat wujud Allah.

\section{Gambaran Lain}

Naskah masih dalam keadaan baik dan bgus, teksnya masih dapat dibaca dengan jelas akan tetapi ada beberapa huruf yang sulit dibaca akibat lipatan yang terjadi pada kertas. Naskah ditulis menggunakan tinta hitam dengan rubrikasi, huruf pada teks ditulis dengan ukuran kecil. 


\section{[Martabat Tujuh]}

$\begin{array}{cccc}\text { MS.TS/SC/PDG/22 } & \text { Arab } & \text { Prosa } & 23 \mathrm{hlm} \\ \text { Kertas Eropa } & 14 \times 22 \mathrm{~cm} & 9 \times 16 \mathrm{~cm} & 17 \text { Baris } / \mathrm{hlm}\end{array}$

\section{Asal Naskah}

Lubuak Minturun, Koto Tangah, Padang

\section{Pengarang/Penyalin}

[Anonim]

\section{Gambaran Isi}

Naskah ini menguraikan tentang martabat wujud, atau yang dikenal dengan martabat tujuh. Setelah basmallah dan shalawat, penulis yang dalam hal ini anonim, masuk kepada pembahasan martabat tujuh dengan sangat gamblang, dimulai dengan ahadiyah, wahdah, wahidiyah, alam arwah, alam misal, alam ajsam dan alam insan. Kemudian secara umum dijelaskankan hubungan masing-masing martabat ini:

Ahadiyah martabat Zat Allah, wahdah martabat sifat Allah, wahidiyyah martabat Asma' Allah, alam arwah alam segala nyawa, alam misal alam segala rupa, alam ajsam alam segala tubuh, alam insan alam segala manusia.

\section{Gambaran Lain}

Naskah masih baik dan bagus, teks nya dapat dibaca dengan baik, namun beberapa teks terakhir robek dan naskah dibungkus dengan sampul dari kertas yang tebal seperti karung semen oleh pemiliknya. Naskah ditulis menggunakan tinta hitam dengan rubrikasi. 


\section{Risalah Peri Tanazul dan Tarqi}

$\begin{array}{cccc}\text { MS.TS/SC/PDG/23 } & \text { Arab } & \text { Prosa } & 21 \mathrm{hlm} \\ \text { Kertas Eropa } & 14,3 \times 22,1 \mathrm{~cm} & 9,3 \times 16,2 \mathrm{~cm} & 17 \text { Baris } / \mathrm{hlm}\end{array}$

\section{Asal Naskah}

Lubuak Minturun, Koto Tangah, Padang.

\section{Pengarang/Penyalin}

[Anonim]

\section{Gambaran Isi}

Naskah ini adalah pembahasan lain mengenai pengajian martabat tujuh yang dikenal dalam terminologi tasawuf muntahi. Namun dalam naskah ini dipakai istilah lain, yaitu martabat tarqi dan martabat tanazzul, martabat naik dan martabat turun. Pembahasan dalam naskah ini terkesan sangat dalam dan rinci, selain menguraikan sisi-sisi filosofis teori emanasi (faidh), juga dipaparkan Isyarat-Isyarat nash terhadap hal demikian. Salah satu pembahasannya, dalam kita lihat dari cuplikan fragmen berikut:

\section{Gambaran Lain}

Naskah masih dalam keadan baik dan bagus, tulisan pada teks masih dapat dibaca dengan jelas, kertasnya pun masih terawat. Naskah ditulis dengan menggunakan tinta hitam dengan rubrikasi. 


\section{Fathurrahman Syeikh Zakaria al-Anshari}

$\begin{array}{cccc}\text { MS.TS/SC/PDG/24 } & \text { Arab } & \text { Prosa } & 31 \mathrm{hlm} \\ \text { Kertas Lokal } & 16,2 \times 21,4 \mathrm{~cm} & 13,2 \times 18 \mathrm{~cm} & 15 \text { Baris } / \mathrm{hlm}\end{array}$

\section{Asal Naskah}

Surau Inyiak Aluma Galudua, Koto Tuo.

\section{Pengarang/Penyalin}

Syeikh Islam Zakaria al-Anshari as-Syafi'i

\section{Gambaran Isi}

Naksah ini membahas masalah-masalah pelik dalam tasawuf, seperti fana' dan kasyf. Naskah ini merupakan syarah (komentar) Syeikhul Islam Syeikh Zakaria al-Anshari terhadap matan (teks) ringkas mengenai masalah-masalah tasawuf yang ditulis oleh Syeikh Wali Ruslan ad-Dimasyqi. Karya monumental Syeikh Zakaria ini menjadi rujukan sangat populer di kalangan ahli tasawuf di Minangakabau. Pada halaman awal terdapat informasi penting perihal judul naskah dan penyalinannya, yaitu:

Kitab fathurrahman bi syarh Risalah as-Syeikh al-Wali Ruslan [li] syeikhil Islam Zakaria al-Anshari wa ta'maduhuhumallahu bi rahmatihi. Amin. Ibtida' min naql hadzi [kitab] yaum ahad 2 jumadil akhir sanah 1381, keluaran Koto Tuo, Bukittinggi.

\section{Gambaran Lain}

Naskah masih dalam kondisi bagus dan baik,begitu juga dengan tulisan dan teksnya yang masaih dapat dibaca dengan jelas. Naskah ditulis dengan menggunakan tinta biru tanpa rubrikasi. 


\section{Syair Tarekat Syeikh Talang Babungo}

MS.TS/SC/PDG/25

Kertas lokal
Arab

$16 \times 21 \mathrm{~cm}$
Prosa

$22 \mathrm{hlm}$

$13,8 \times 17,5 \mathrm{~cm}$

23 Baris/hlm

\section{Asal Naskah}

Sungai Pagu, Solok Selatan.

\section{Pengarang/Penyalin}

Tuanku Syeikh Talang Babungo

\section{Gambaran Isi}

Naskah ini secara jelas menyebutkan paham wahdatul wujud, mengenai keutamaan orang-orang yang telah sampai kepada maqam wahdah wujud. Permisalan yang ditulis dalam teks bergaya sya'ir cukup menawan, sehingga hal ini menjadi daya tarik sendiri ketika membacanya. Pada awal teks disebutkan informasi pengambilan sya'ir ini, yaitu:

Inilah sya'ir Tharikat namanya

Pada Tuanku Syeikh Talang Babungo

Selanjutnya, pengarang membuka sya'irnya dengan basmallah, dan diawali dengan menyebut nama seorang tokoh yang disinyalir sebagai seorang raja, dinama masa penulis teks menyalin naskah ini. nama tokoh yang disebut ialah Johan Perkasa Syah Alam. Dibait berikutnya disebutkan bahwa tokoh yang dimaksud ialah seorang perempuan.

Adapun bait yang secara jelas menyebutkan hal tersebut adalah:

Wahdatul wujud besar kemenangannya

Pada sakaratul maut nyata terpeliharanya

Pada hari kiamat terlindung padanya

Pada hadharat Allah disanalah tempatnya

Tilik, Allahumma, pada intan dan batu

Haq dan syai dua bersuatu

Pada ombak dan lau disana tentu

Wahdatul wujud namanya itu 
Hendaklah engkau pandang kapas dan kain

Bangsanya satu namanya berlain

Satukan, Allahumma, zhahir dan bathin

Itulah ilmu kesudahan main

\section{Gambaran Lain}

Naskah masih dalam kondisi baik dan bagus, begitu juga dengan kertas, teks dan isinya yang terawat dan masih dapat dibaca dengan jelas. Naskah ditulis menggunakan tinta hitam tanpa rubrikasi. 


\section{ljazah Tarekat Tuanku Kampung Sariak}

$\begin{array}{cccc}\text { MS.TS/SC/PDG/26 } & \text { Arab } & \text { Prosa } & 4 \mathrm{hlm} \\ \text { Kertas Lokal } & 18,2 \times 22,5 \mathrm{~cm} & - & 24 \text { Baris } / \mathrm{hlm}\end{array}$

\section{Asal Naskah}

Surau Syeikh Muhammad Bashir

\section{Pengarang/Penyalin}

Syeikh Abdul Majid bin Muhammad Amin bin Muhammad Bashir

\section{Kolofon:}

Ajaztuhu dzalika wa ana Abduz dzalil al-faqir al-haqir al-masakin al-Muqim fi biladillahil hannan al-mannan as'alullahal 'azhima an yutsbitahu wa yuridahu 'ilmahu wa nurahu wa la yansa min shalihi doa-i yauman wa lailatan. Huwa ana ismuhu Syeikh Abdul Majid alAsy'ary was Syafi'i al-khalidi an-Naqsyabandi Kabupaten Pasaman Barat, Lubuk Landur, 1393.

\section{Gambaran Isi}

Naskah ini menjelaskan ijazah, petanda bahwa seseorang bernama Husein gelar Tuanku Kampuang Sariak, telah menyelesaikan pelajaran Tarekat Naqsyabandiyah al-Khalidiyah dan berhak menyebarluaskannya. Selain menjelaskan hal di atas, dalam naskah ini juga disebutkan silsilah penerimaan Tarekat Naqsyabandiyah ini mulai dari Syeikh Abdul Majid, sebagai pemberi ijazah, sampai kepada Rasulullah. Syeikh Abdul Majid sendiri menerima tarekat ini dari ayahnya Syeikh Muhammad Amin, beliau menerima dari ayahnya Syeikh Muhammad Bashir (Syeikh Lubuk Landur pertama), sedangkan Syeikh ini mengambil dari Syeikh Abdurrahman Asahan, Syeikh Asahan ini langsung mengambil kepada Syeikh Jabal Abi Qubais di Mekkah al-Mukakarramah. Setelah menguraikan silsilah, Syeikh Abdul Majid, kemudian membentangkan nasihatnasihatnya kepada si-Husein tersebut, untuk tetap memegang 
teguh ajaran agama berdasarkan Al-Qur'an dan Sunnah. Tetap beramal dengan Ahlussunnah wal Jama'ah dan mengamalkan setiap wirid yang telah dipelajari dalam suluk-nya.

\section{Gambaran Lain}

Naskah merupakan selembar kertas folio yang dilipat menjadi empat. Penulisannya berdasarkan lipatannya, seperti rupa buku. Naskah dalam keadaan baik. Ditulis dengan khat naskhi yang cukup rapi. Pada akhir naskah terdapat 3 buah mahor, SyeikhSyeikh pendahulu di Surau Lubuk Landur Pasaman Barat. 


\section{Nazam Tawassul Tarekat Naqsyabandiyah}

$\begin{array}{cccc}\text { MS.TS/SC/PDG/27 } & \text { Arab - Melayu } & \text { Prosa } & 18 \mathrm{hlm} \\ \text { Kertas Lokal } & 16 \times 21 \mathrm{~cm} & 12,8 \times 18 \mathrm{~cm} & 22 \text { Baris } / \mathrm{h} / \mathrm{m}\end{array}$

\section{Asal Naskah}

Surau Syeikh Muhammad Bashir

\section{Pengarang/Penyalin}

Syeikh Abdul Majid bin Muhammad Amin bin Muhammad Bashir

\section{Kolofon:}

Telah sudah tamatlah kitab shalawat kira-kira pukul dua belas pada hari ahad sembilan hari bulan Dzulqa'idah hijrah Nabi, hamba katakan tahun seribu tiga ratus tiga puluh empat. Tamat tulisan hijrah Nabi yang akhir zaman pada sekalian hamba yang manusia, hamba yang hinanya, hamba yang lemah/dha'if dan miskin sudahlah [ha]bis perkataan saya sudah pula terucap nama dan gelar Abdul Majid khani...

\section{Gambaran Isi}

Naskah ini berupa nazham dalam bahasa melayu mengenai doa tawassul kepada Ahli Silsilah Tarekat Naqsyabandiyah. Inti dari doa tawassul ini ialah memohon limpahan rahmat dan karunia ma'rifat kepada Allah dengan menyebut nama-nama ahli silsilah Tarekat Naqsyabandi sebagai wasilah dalam berdoa. Awal doa ini menyebutkan nama-nama silsilah yang ada di Lubuk Landur sendiri, kemudian ahli silsilah yang berada di Mekkah, hingga sampai pertaliannya dengan Rasulullah. Awal nazham ini dibuka dengan:

Ya Allah ya Tuhan-ku

Tilik olehmu akan diriku

Siang dan malam sepanjang waktu-ku

Inilah pintak-ku ya Tuhan-ku 
Ampuni olehmu akan dosa-ku

Demikian dosa ibu bapak-ku

Sekalian kaum muslimin kaum kerabat-ku

Sekalian jama'ah ahli guru-ku

Janganlah Tuan hamba hampakan akan pintakku

Tiada siapa yang lain tempat pintak-ku

Berkat himmah pertama guru-ku

Syeikh Muhammad Bashir akan rabithah-ku

Dengan himmah tuan Syeikh Abdurrahman

Tuan Syeikh Abdul Wahhab mursyid yang aman

Berkah himmah sekalian silsilah Naqsyabandiyah

Akan menolong menyampaikan kami

\section{Gambaran Lain}

Naskah ini dalam keadaan baik dan lengkap. Teks ditulis dengan khat naskhi yang cukup rapi sehingga mudah dibaca dengan baik. Diawal teks, terdapat ilustrasi berupa masjid, yang bertuliskan di bawahnya basmallah. 


\section{Nahjatus Shalikin}

$\begin{array}{cccc}\text { MS.TS/SC/PDG/28 } & \text { Arab }- \text { Melayu } & \text { Prosa } & 94 \mathrm{hlm} \\ \text { Kertas Lokal } & 13 \times 22 \mathrm{~cm} & 10 \times 16 \mathrm{~cm} & 18 \text { Baris } / \mathrm{hlm}\end{array}$

\section{Asal Naskah}

Surau Kinali (naskah ini berasal dari pegangan Bapak Murkilim)

\section{Pengarang/Penyalin}

Syeikh Husein Abdusshamad al-Khalidi Talu

\section{Kolofon:}

... tiada yang memberi taufik dan perjuntuk melainkan Allah, kepada-Nya aku kembali dan atasnya aku berserah. Tamat tarikhuhu pada dzil qa'idah az-Zaman sanah 1325. was Salam sakiyatul khatam allafahu al-faqir al-haqir ila 'afuwwi rabbihi Syeikh Husain bin Abdusshamad al-Khalidi Kajai Sungai Lumpang fi Makkah.

\section{Gambaran Isi}

Naskah ini merupakan uraian yang cukup luas mengenai Tarekat Naqsyabandiyah dan ajaran-ajarannya. Dimulai dengan tata cara pemba'iatan, urutan pelajaran-pelajaran serta wirid-wirid yang diamalkan selama Suluk. Dari hasil perbandingan teks, naskah ini merupakan terjemahan dari kitab Masiratul Hikam karya Syeikh Sulaiman Zuhdi, meskipun Syeikh Husein bin Abdusshamad tidak menyebutkan hal tersebut, malah pada sampul disebutkan bahwa naskah ini dikarang oleh Syeikh Husein sendiri.

\section{Gambaran Lain}

Naskah dalam keadaan baik, lengkap. Teks ditulis dengan khat riq'ah yang cukup rapi, sehingga dapat dibaca dengan mudah. Tinta yang digunakan dalam penulisan teks ialah hitam dengan rubrikasi. 


\section{Kifayatul Muhtajin}

$\begin{array}{cccc}\text { MS.TS/SC/PDG/29 } & \text { Arab - Melayu } & \text { Prosa } & 20 \mathrm{hlm} \\ \text { Kertas Lokal } & 16,7 \times 22,5 \mathrm{~cm} & 10 \times 15 \mathrm{~cm} & 15 \text { Baris } / \mathrm{hlm}\end{array}$

\section{Asal Naskah}

Surau Baru Syeikh Abdurrahman

\section{Pengarang/Penyalin}

Syeikh Abdurra'uf Singkel

\section{Kolofon:}

...dan pertemuannya dengan silsilah Qadiriyyah yakni jalan Syeikh Abdul Qadim Jailani, dan pertemuannya dengan dia. Wallahu a'lam. Ini kitab dinamai dengan Kifayatul Muhtajin ghafarallahu lahu wa liwalidayya wa li jami'il muslimin wallahu a'lam.

\section{Gambaran Isi}

Naskah ini menguraikan masalah-masalah pelik seputas tasawuf muntahi, seperti perihal fana, martabat wujud, dan lainnya. Berdasarkan mukaddimah teks, penulisan karya ini merupakan titah dari permaisuri yang berkuasa di kerajaan Aceh Darussalam. Pada akhir naskah disebutkan pertalian silsilah Tarekat Syattariyyah dan silsilah Tarekat Qadiriyyah, yang diterima oleh Syeikh Abdurra'uf Singkel dari gurunya Syeikh Ahmad Qusyasi di Medinah al-Munawwarah.

\section{Gambaran Lain}

Naskah dalam keadaan baik dan lengkap. Teks ditulis dengan khat yang tergolong kepada naskhi yang cukup rapi, sehingga mudah dibaca dengan mudah. Teks ditulis dengan tinta hitam dengan rubrikasi. 


\begin{tabular}{cccc}
\multicolumn{4}{c}{ Al-Haqiqah al-Wafiqah li al-Syari'ah } \\
Syarh Tuhfat al-Mursalah ila Ruh al-Naby \\
MS.TS/SC/PDG/30 & Arab & Prosa & $64 \mathrm{hlm}$ \\
Kertas Lokal & $16 \times 20,5 \mathrm{~cm}$ & $12 \times 16 \mathrm{~cm}$ & - Baris/hlm
\end{tabular}

\section{Asal Naskah}

Surau Baru Syeikh Abdurrahman

\section{Pengarang/Penyalin}

Syeikh Muhammad Ibn Fadhullah al-Burhanpuri

\section{Gambaran Isi}

Naskah ini merupakan penjelasan rinci terhadap martabat tujuh yang mulanya tertuang dalam naskah Tuhfatul Mursalah ila Ruhin Nabi. Naskah tuhfah sendiri merupakan sumber utama pengajian martabat tujuh di nusantara. Berdasarkan mukaddimah naskah ini diketahui alasan penulisannya, yaitu karena tekh tuhfah telah dipahami dengan tidak tepat oleh sebagian kalangan, sehingga sebahagian lain menganggap teks tuhfah merupakan tasawuf sempalan. Maka Syeikh Muhammad ibn Fadhlullah merasa perlu meluruskan pemahaman para pembaca tersebut, dengan cara menulis sebuah uraian (syarah) terhadap teks matan-nya.

\section{Gambaran Lain}

Naskah dalam keadaan baik dan lengkap. Teks ditulis dengan khat yang tergolong kepada naskhi yang cukup rapi, sehingga mudah dibaca dengan mudah. Teks ditulis dengan tinta hitam tanpa rubrikasi. 


\section{Jawahir al-Haqaiq}

MS.TS/SC/PDG/31

Kertas Lokal
Melayu-Arab

$17 \times 22 \mathrm{~cm}$

Prosa

$18 \mathrm{hlm}$

$13,1 \times 18 \mathrm{~cm}$

10 Baris/hlm

\section{Asal Naskah}

Bintungan Tinggi Pariaman

\section{Pengarang/Penyalin}

Syamsuddin Sumatrani

\section{Gambaran Isi}

Naskah ini berbicara tentang martabat tujuh dan wahdatul wujud yang terinspirasi dari karya al-Burhanpuru yang berjudul Tuhfatu alMursalah, naskah Jawahirul Haqaiq ini pernah mencapai intelektual tertinggi di nusantara pada masanya, akan tetapi kitab ini juga mendapat tantangan keras dari Nuruddin ar-Raniri seorang ulama yang sangat fasih berbahasa Melayu di Aceh.

\section{Gambaran Lain}

Naskah ini masih sangat baik dan terawat, teksnya pun masih dapat dibaca jelas, naskah ini merupakan salinan dari kitab Jawahirul Haqaiq karangan Sumatrani, pada naskah ini tidak disebutkan siapa penyalinnya. Naskah ini ditulis menggunakan tinta hitam dengan rubrikasi. 


\section{Hizb al-Bahr}

$\begin{array}{cccc}\text { MS.TS/SC/PDG/32 } & \text { Melayu-Arab } & \text { Prosa } & 18 \mathrm{hlm} \\ \text { Kertas Lokal } & 17,6 \times 23,2 \mathrm{~cm} & 13,5 \times 11,7 \mathrm{~cm} & -\end{array}$

\section{Asal Naskah}

Surau Barong Barong Balantai

\section{Pengarang/Penyalin}

Anonim

\section{Gambaran Isi}

Naskah ini berisikan tentang zikir-zikir Tarekat Sazyliyah yang kita kenal dengan hidzib bahar, bagi karangan sadzili sendiri hidzib ini merupakan sebuah spiritual yang berisikan tentang nama-nama Allah dan simbol-simbol sufi yang menjadikannya sebagai hidzib yang mistis. Setelah hidzib ini, terdapat juga sya'ir yang ditulis oleh Syeikh Ismail Simabur.

\section{Gambaran Lain}

Naskah ini dalam keadaan baik dan bagus, teksnya masih dapat dibaca. Naskah ini memiliki terjemahan gantung dengan bahasa melayu di bawahnya. Ditulis menggunakan tinta hitam tanpa rubrikasi. 
Martabat Tujuh dan Azimant Lubuak Ipuah

$\begin{array}{cccc}\text { MS.TS/SC/PDG/33 } & \text { Melayu-Arab } & \text { Prosa } & 502 \mathrm{hlm} \\ \text { Kertas Lokal } & 18 \times 23 \mathrm{~cm} & 14,3 \times 17,8 \mathrm{~cm} & 18 \text { Baris } / \mathrm{hlm}\end{array}$

\section{Asal Naskah}

Lubuk Ipuah Pariaman

\section{Pengarang/Penyalin}

Anonym

\section{Gambaran Isi}

Naskah ini berisikan tentang azimat, mantara dan obat-obatan yang terdiri dari doa-doa atau penggalan-pengalan ayat Al-Qur'an yang pada umumnya didapatkan oleh para ahli hakikat yang begitu ampuh untuk penyakit-penyakit, gangguan makhluk halus dan perbuatan orang yang jahat. Sebelumnya terlebih dahulu naskah ini dimulai dengan kajian Nur Muhammad, dilanjutkan dengan martabat tujuh dan di selingi dengan azimat dan mantra. 


\section{Qasyidah al-Mudhariyah}

$\begin{array}{cccc}\text { MS.TS/SC/PDG/34 } & \text { Melayu-Arab } & \text { Prosa } & 13 \mathrm{hlm} \\ \text { Kertas Lokal } & 22,5 \times 17,2 \mathrm{~cm} & 13,7 \times 19 \mathrm{~cm} & 13 \text { Baris } / \mathrm{hlm}\end{array}$

\section{Asal Naskah}

Pesisir, Batang Kapas

\section{Pengarang/Penyalin}

\section{Gambaran Isi}

Naskah ini berisikan tentang fadilah sebuah Qasidah yang berisikan pujian-pujian kepada rasul, sahabat dan alim ulama, pengarangnya adalah penganut Tarekat Sadziliah, di ada banyak bait yang terdapat pada qasidah ini. Seperti yang kita ketahui bahwa sadziliah terkenal dengan kata-kata yang dalam dan simbol-simbol sufi yang terdapat pada kata-kata nya. Qasidah ini diberi nama "Qasidah al Mudhariyah fi as shalawat 'ala khairi al barriyah".

\section{Gambaran Lain}

Naskah ini cukup terawat, namun lembarannya tidak lengkap. Pada awal naskah ini terdapat gambaran "sebuah risalah kecil tentang fadhilah Qasidah al Mudhariyah fi as shalawat 'ala khairi al-barriyah yang mualifnya ialah Syeikh Muhammad Syarif al Busairi". 


\section{Syair Martabat Tujuh}

$\begin{array}{cccc}\text { MS.TS/SC/PDG/35 } & \text { Melayu-Arab } & \text { Prosa } & 15 \mathrm{hlm} \\ \text { Kertas Lokal } & 16 \times 21 \mathrm{~cm} & 13,8 \times 17,7 \mathrm{~cm} & 17 \text { Baris } / \mathrm{hlm}\end{array}$

\section{Asal Naskah}

Koto Tuo Bukittinggi

\section{Pengarang/Penyalin}

Syeikh Ismail bin Aluma Koto Tuo

\section{Gambaran Isi}

Naskah ini merupakan tentang pengajian martabat tujuh beserta beberapa keteraangn sebagian orang yang menolak dan meninggalkan ajaran ini, naskah ini dibuat dalam bentuk sya'ir dalam catatan harinya oleh tunku Ismail ibn Syeikh Aluma Koto Tuo. Memang yang kita ketahui martabat tujuh adalah pengajian khas Sathariyah, namun uniknya pengajian ini ditulis dalam bentuk sya'ir seperti:

Kita kaji martabat tujuh

Pahamnya panjang payahlah tubuh

Jalan yang hamper menjauh jauh

Karena i'tikad banyak yang cabuh

Ilmu yang batil tuan dengarkan

Tujuh belas lekas pada bilangan

Maso dahulu orang amalkan

Sekarang kini orang batalkan

\section{Gambaran Lain}

Naskah ini masih dalam keadaan baik dan terawat, teksnya masih dapat di baca namun sya'ir ditulis dalam bahasa Minang dengan mengubah vokal a dalam bahasa Melayu dengan o kedalam bahasa Minang seperti "masa" kepada "maso". 
Tuhfatul Ahbab ila Suluki Thariqil Ashhab

Syarah Silsilah Dzahab

MS.TS/SC/PDG/36

Kertas Eropa
Arab

$20 \times 19,5 \mathrm{~cm}$
Prosa

$120 \mathrm{hlm}$

19 Baris/hlm

\section{Asal Naskah}

Surau Batangkapeh, Pesisir Selatan

\section{Pengarang/Penyalin}

Darwisy Ahmad at-Tharbazuni

\section{Kolofon:}

Wa qad waqa'a al-firagh 'an tahrir as-Syarhi al-Lathif min naskhatis Syarih al-latief an-Naqsyabandi al-Muradi al-'Arifi bi Darwisy Ahmad at-Tharbazuni az-zharif fi sanah ihda wa tis'ina wa mi'ah wa alf min hijratin man lahul 'izz was syarf. Wa qad firaghil khatti al-faqir al-haqir al-mu'taruf biz zanbi wat taqshir al-Hajj Muhammad 'Aqib Ibn Haji Abdul latief Batang Kapas.

\section{Gambaran Isi}

Naskah ini merupakan komentar terhadap salah satu teks tasawuf khusus dalam Tarekat Naqsyabandiyah yang teks awalnya dikarang oleh Syeikh Muhammad Murad an-Naqsyabandi. Teks awal ini berjudul Silsilah az-Zahab.

Dalam naskah isi diuraikan pokok-pokok ajaran dasar mengenai Tarekat Naqsyabandiyah, seperti perihal bai'at, suluk, dan lainnya. Penjelasan yang mendominasi dalam naskah ini yaitu mengenai riwayat ringkas ahli Silsilah Naqsyabandiyah. Dengan demikian, naskah ini merupakan salah satu literatur langka mengenai ajaran Tarekat Naqsyabandiyah di Minangkabau yang keberadaan tidak banyak diketahui oleh peneliti-peneliti sebelumnya. 


\section{Gambaran Lain}

Naskah dalam keadaan lengkap. Pada bagian tengah naskah terdapat kerusakan kertas yang mengganggu pembacaan teks, selain itu juga terdapat tinta yang melebar akibat rembesan air. Khat yang digunakan dalam naskah ini yaitu naskhi yang tergolong rapi. Tinta yang digunakan berwarna hitam dengan rubrikasi. 


\section{Doa Munajat al-Marhum \\ Syeikh Abdul Wahhab Babusslam}

$\begin{array}{cccc}\text { MS.TS/SC/PDG/37 } & \text { Arab-Melayu } & \text { Puisi } & 5 \mathrm{Hlm} \\ \text { Kertas Lokal } & 16 \times 20,5 \mathrm{~cm} & 12 \times 16 \mathrm{~cm} & 21 \mathrm{Baris} / \mathrm{hlm}\end{array}$

\section{Asal Naskah}

Surau Syeikh Muhammad Bashir, Pasaman Barat

\section{Pengarang/Penyalin}

Syeikh Abdul Wahab Rokan al-Khalidi Naqsyabandi

\section{Gambaran Isi}

Naskah ini berisi tentang nazham (sya'ir) yang berisi munajat (doa-doa) tawassul dengan ahli Tarekat Naqsyabandiyah. Inti doa ini memohon kepada Allah akan limpahan karunia dan rahmat dengan menyertakan nama-nama tokoh-tokoh tarekat sesuai dengan runtun silsilahnya.

Di awal teks ini terdapat gambaran yang menjelaskan kaifiyyat pengamalannya serta keutamaan ketika membacanya:

Adapun munajat ini dibaca sembarang waktu, terutama sebelum masuk waktu Subuh sesudah lepas tengah malam, lebih jauh perhatikanlah wasiat almarhum: katanya hendaklah kuat-kuat bangun pada waktu sahur dan beramal ibadah dan meminta doa karena waktu itu tempat doa maqbul, terutama pada waktu sahur malam Jum'at.

\section{Gambaran Lain}

Naskah dalam keadaan lengkap dan baik. Khat yang digunakan dalam naskah ini yaitu naskhi yang tergolong rapi. Tinta yang digunakan berwarna hitam tanpa rubrikasi. 


\section{Asrarul lbadah}

MS.TS/SC/PDG/38

Arab

Prosa

$120 \mathrm{hlm}$

Kertas Eropa

$16 \times 20,5 \mathrm{~cm}$

$12 \times 16 \mathrm{~cm}$

10 Baris/hlm

\section{Asal Naskah}

Surau Syeikh Muhammad Bashir, Pasaman Barat

\section{Pengarang/Penyalin}

Syeikh Mustafa Kamal Lubuak Landua

\section{Gambaran Isi}

Naskah ini menguraikan masalah ibadah dan rahasia-rahasia pengalamannya yang mencakup ruh ibadah dalam terminologi tasawuf. Dalam mukaddimahnya, penulis menyebutkan bahwa alasan utama penyusunan kitab ini untuk menjelaskan kepada kaum muslimin umum bagian-bagian fundamental dalam ibadah dan rahasia-rahasianya sehingga inti ibadah untuk taqarrub ilallah tercapai. Dalam mukaddimah tersebut juga dijelaskan bahwa penyusunan kitab ini bersumber dari kitab-kitab ahli tasawuf yang besar-besar.

Mukaddimah yang dimaksud adalah:

...kitab ini membukakan beberapa rahasia di dalam beribadah, supaya disampaikan Tuhan segala maksud dan hajat. Wahai ikhwan taulan sahabat, kalau ingin mendapatkan syorga di dunia dan syorga di akhirat beramallah dengan ini kitab "Asrar al-Ibadah" yang telah hamba kutip dari kitab-kitab ahli ibadah dan orang-orang kiramah, dan bukan diambil dari kitab-kitab yang sesat dan bid'ah dhalalah, tapi adalah kitab yang hebat-hebat yang menjadikan orang selamat dunia akhirat.

\section{Gambaran Lain}

Naskah dalam keadaan baik dan lengkap. Teks ditulis menggunakan tinta hitam tanpa rubrikasi. Jenis tulisan yang digunakan, yaitu naskhi yang cukup rapi sehingga mudah dibaca. 


\section{Sullamul Mustafidin}

\section{Syarah Manzumah Wajizah wa Mafhumah}

$\begin{array}{cccc}\text { MS.TS/SC/PDG/39 } & \text { Arab - Melayu } & \text { Prosa } & 40 \mathrm{HIm} \\ \text { Kertas Eropa } & 16 \times 20,5 \mathrm{~cm} & 12 \times 16 \mathrm{~cm} & 17 \text { Baris } / \mathrm{hlm}\end{array}$

\section{Asal Naskah}

Sicincin, Padang Pariaman

\section{Pengarang/Penyalin}

Syeikh Ibrahim al-Kurani

\section{Gambaran Isi}

Naskah ini merupakan syarah (komentar) terhadap sebuah karya Syeikh Ahmad Qusyasi yang berbentuk manzhumah (puisi) yang tidak disebut judul asalnya. Karya ini berbicara mengenai pengertian-pengertian tasawuf mencakup martabat tujuh serta persoalan-persoalan lain seputar tasawuf falsafi. Pada mukaddimah karya ini, Ibrahim Kurani, sebagai penulis syarah menyebutkan alasan penulisan uraian ini berdasarkan kapasitas manzumah Syeikh Ahmad Qusyasi yang menghimpun ilmu-ilmu hakikat. Ini disebutkan dalam kalimat:

... dan telah sanya dikarang oleh segala ulama dari pada ilmu ini barang yang memadai akan kita daripada segala kitab yang besarbesar dan yang mukhtashar maka dibalas Allah karenanya akan mereka itu pada kita dengan khair..., maka setengah daripada mukhtashar itu manzhumah syeikh kita dan ikutan kita kepada jalan Allah yang 'arif billah yang sempurna lagi yang menyempurnakan yang hening kamal dalam negeri kita ini maka menuntut khair-lah aku kepada Allah dengan beberapa kali bahwa menjadikan baginya suatu syarah maka sempurnalah baginya suatu syarah yang menyatakan maknanya dengan bahasa kita...

\section{Gambaran Lain}

Naskah dalam keadaan lengkap dan baik. Khat yang digunakan dalam naskah ini yaitu naskhi yang tergolong rapi. Tinta yang digunakan berwarna hitam dengan rubrikasi. 
[Nasihat supaya Memegang Syariat dan Tarekat]

$\begin{array}{cccc}\text { MS.TS/SC/PDG/40 } & \text { Arab }- \text { Melayu } & \text { Prosa } & 8 \mathrm{Hlm} \\ \text { Kertas Lokal } & 16 \times 20,5 \mathrm{~cm} & 12 \times 16 \mathrm{~cm} & 19 \text { Baris } / \mathrm{hlm}\end{array}$

\section{Asal Naskah}

Surau Jembatan Kuniang, Koto Baru, Sungai Pagu

\section{Pengarang/Penyalin}

Muhammad Ridhwan Datuak Tambijo

\section{Gambaran Isi}

Naskah berisi tentang berpegang teguh kepada syari'at dan tarekat. Dalam naskah ini, si-penulis dalam ini Muhammad Ridhwan menggunakan bahasa-bahasa familiar, sehingga terkesan lebih terasa dekat dengan para pembacanya. Si-penulis menyebut dirinya dalam naskah tersebut dengan ayahanda, sedangkan untuk para pembaca dipanggil dengan anak-anakku. Di antara kutipan awal naskah ini yaitu:

Kemudian daripada itu wahai anak-anakku rahimakumullah, sebelum ayahanda menguraikan apa-apa yang terlintas dan terguris-guris di dalam hati, terlebih dahulu marilah kita bersyukur kepada Allah Subhanahu wa Ta'ala, alhamdulillah yang menciptakan kita dari pada tiada kepada ada, dan melimpahkan taufik dan hidayatnya kepada kita, hingga dapat kita merasai hidup, dan mendengar dengan telinga, dan melihat dengan mata dan merasai lezat dan manis dan pahit dengan lidah, serta bergerak dengan anggota, yang semuanya itu hendaklah berpedoman kepada Kitabullah dan hadis.

\section{Gambaran Lain}

Naskah dalam keadaan lengkap dan baik. Khat yang digunakan dalam naskah ini yaitu riq'ah yang tergolong rapi. Tinta yang digunakan berwarna biru. 


\section{Silsilah Tarekat Nuraniyyah Rabbaniyyah \\ Muhammadiyah Sammaniyyah}

$\begin{array}{cccc}\text { MS.TS/SC/PDG/41 } & \text { Arab }- \text { Melayu } & \text { Prosa } & 1 \mathrm{Hlm} \\ \text { Kertas Lokal } & 16 \times 20,5 \mathrm{~cm} & 12 \times 16 \mathrm{~cm} & 23 \mathrm{Baris} / \mathrm{hlm}\end{array}$

\section{Asal Naskah}

Surau Jembatan Kuniang, Koto Baru, Sungai Pagu

\section{Pengarang/Penyalin}

Muhammad Ridhwan Datuak Tambijo

\section{Gambaran Isi}

Naskah ini merupakan catatan penting seputar genealogi (silsilah) Tarekat Nuraniyyah Sammaniyyah. Di mana Buya Muhammad Ridhwan (w. 1982) menerima tarekat tersebut dari seorang ulama bernama Syeikh Muhammad Khusain, silsilah ini hingga berlanjut kepada Syeikh Muhammad Saman al-Madani, dan akhirnya bermuara kepada Rasulullah shallallahu 'alaihi wa sallam. Kutipan awal silsilah ini ialah:

... kemudian daripada itu, faqir ilallah al-ghani subhanahu wa ta'ala, Muhammad Ridhwan cucu Tuanku Rajo Disambah di Koto Baru Sungai Pagu, telah menurunkan Tarekat Nuraniyyah Rabbaniyyah Muhammadiyyah Sammaniyyah dengan ijazah Tarekat itu kepada Ridhwan gelar Datuak Tambijo Koto baru, aku mengambil dari guruku Syeikh Muhammad Khusain...

\section{Gambaran Lain}

Naskah dalam keadaan lengkap dan baik. Khat yang digunakan dalam naskah ini yaitu naskhi yang tergolong rapi. Tinta yang digunakan berwarna biru. 


\section{[Wathsiqatul Wafiyah]}

$\begin{array}{cccc}\text { MS.TS/SC/PDG/42 } & \text { Arab - Melayu } & \text { Prosa } & 16 \mathrm{hlm} \\ \text { Kertas Eropa } & 19,5 \times 26,8 \mathrm{~cm} & 15,5 \times 22,3 \mathrm{~cm} & 21 \text { Baris } / \mathrm{hlm}\end{array}$

\section{Asal Naskah}

Kutub khanah Maninjau

\section{Penyalin/Pengarang}

Utsman bin Abdullah bin Aqil

\section{Gambaran Isi}

Naskah ini berbicara tentang Tarekat Naqsyabandiyah beserta para mursyd-nya, naskah ini menerangkan tentang Tarekat Naqsyabandiyah yang benar dengan tarekat yang melenceng, begitu juga dengan para mursyd-nya. Naskah ini terdiri dari 5 pasal, pasal pertama berbicara tentang setengah ketinggian pangkatan derajat Tarekat Naqsyabandi dan sufiyah yang benar dengan segala syaratnya. Pasal kedua berbicara tentang penguatan syara'terhadap orang yang melintangi atas sufiyah yang benar yang tersebut pada pasal pertama, pasal ketiga berbicara tentang penguatan syara' terhadap orang yang mengaku sufi ketika masuk ke dalam Tarekat Naqsyabandiyah, pasal ke empat berbicara tentang kesalahan yang terjadi pada para ahli tarekat yang mengaku masuk Tarekat Naqsyabandiyah padahal ia tidak mengikuti persaratan untuk masuk kepada Tarekat Naqsyabandiyah, pasal kelima berbicara tentang sebutan atas segala subhat yang ada pada Tarekat Naqsyabandiyah dan dengan segala syubhat itu yang masuk Tarekat Naqsyabandiyah dapat prasangka bahwa yang menolak syubhat ini itu yang salah, dan pada pasal ini juga terdapat segala dalil yang menolak segala syubhat itu. 


\section{Gambaran Lain}

Pada klofonnya tertulis: ini terjemahan dari kitab al-Watsiqatu al Wafiyah fi 'uluwi syaani thariqati as sufiyyati. Artinya, kepercayaan yang menyampaikan segala haq di dalam ketinggian "thariqat sufiyah radhiallahu 'anhu karangan hamba yang dha'if Utsman bin Abdullah bin Aqil". 


\section{[Martabat Tujuh dan Azimat]}

$\begin{array}{cccc}\text { MS.TS/SC/PDG/43 } & \text { Arab - Melayu } & \text { Prosa } & 16 \mathrm{hlm} \\ \text { Kertas Eropa } & 12,3 \times 20 \mathrm{~cm} & 15,5 \times 22,3 \mathrm{~cm} & 21 \text { Baris } / \mathrm{hlm}\end{array}$

\section{Asal Naskah}

Pasia Bukittinggi

\section{Penyalin/Pengarang}

Anonym

\section{Gambaran Isi}

Naskah ini merupakan hasil dari aplikasi pengajian martabat tujuh yang menjadikannya sebuah, azimat yang ampuh beserta dengan ilustrasi seperti: tongkat Nabi Musa, pedang Ali, gunting dan beberapa ilustrasi Allah, Muhammad beserta para Khulafa ar-Rasyidin. pengajian martabat tujuh itu dapat kita lihat pada teks seperti: semalam dikandung bendanya hawa namanya Allah katanya ahdiyah nama titinya apabila sampai tiga hari tiga malam dikandung bendanya nur Allah namanya, ana Allah katanya wahdah nama martabatnya...

\section{Gambaran Lain}

Naskah ini seperti naskah azimat yang ditulis di atas kertas sepanjang kurang lebih 2 meter akan tetapi sudah terputus putus akibat termakan usia, namun kondisi teksnya baik dan bisa dibaca dengan jelas. Naskah ditulis menggunakan tinta hitam dengan rubrikasi. 


\section{Nazham Usiat}

MS.TS/SC/PDG/44

Kertas Lokal

\author{
Arab - Minang
}

$16 \times 21 \mathrm{~cm}$
Puisi

$60 \mathrm{hlm}$

\section{Asal Naskah}

Masjid Syeikh Muhammad Sa'di Bonjol

\section{Pengarang/Penyalin}

Anonim

\section{Gambaran Isi}

Naskah berisi tentang kajian tasawuf dalam bentuk nazham (sya'ir), namun 4 halaman pertama berisi cacatan-catatan khusus. Halaman pertama berisi catatan hari baik mendirikan rumah. Halaman kedua berisi tentang zikir Tarekat Naqsyabandiyah, halaman ketiga berisi tabel menentukan awal bulan hijriyah (ilmu hisab) dan halaman keempat kosong. Baru pada halaman kelima berisi sya'ir tasawuf sampai satu halaman sebelum akhir (hal. 31). Satu halaman terakhir berisi cacatan mengenai syarat-syarat membuat azimat (rajah) dan kaifiyah mendirikan rumah.

Sya'ir didahului oleh muqaddimah dan menerangkan maksud menyusun sya'ir, diungkap sebagai berikut:

Aku mulai dengan bismillah Membuka berkat kepada Allah

Apa dimaksud jangan diubah

Begitu kata Habibullah Rahmah (baris 1-2)

Sebab nazam aku karangkan

Melihat laku segala tolan

Ilmu yang sedikit dipadikan

Asli boleh mencari makan (baris 15-16)

Setengah pula lakunya umat

Bamasiang-masiang mencari pangkat

Belum berguna amal dan taat

Tidak terkenal jalan akhirat (baris 17-18) .. (dan seterusnya) 
Dari muqaddimah diketahui bahwa sebab disusunnya nazam karena melihat banyak masyarakat yang lupa denga akhirat, hanya sibuk dengan harta dan pangkat. Selanjutkan penulis menerangkan jalan menuju akhirat dengan gaya bahasa khas sya'ir Melayu.

\section{Gambaran Lain}

Penomoran halaman dilakukan penulis di tengah atas naskah. Susunan sya'ir naskah ini persis menyerupai syi'ir Arab, memakai sathar awal (bagian satu) dan sathar tsani (bagian kedua) yang dibatasi oleh spasi di tengah-tengahnya. Susunannya memakai sajak aaaa.

Penulis sya'ir tidak tercantung pada naskah, Cuma ada gambaran mengenai waktu penulisan syi'ir, yaitu tanggal 25 Jumadil Akhir tahun 1340 H (1918 M). Ini dilsyaratkan Penulis

Tamatlah khabar nazham usiat

Pada hari $a r b a^{\prime}$ kalam diangkat

Di kampung kota (.........)

Masuk 25 jumadil akhit mulai tamat

Kalau salah meminta hormat

Kepada saudara kaum kerabat

Pada tahun 1340 sehari menulis

Kalau salah perkataan hendaklah kikis (hal. 59)

\section{Kondisi Fisik}

Naskah dalam keadaan baik dan mudah dibaca. Ditulis dengan khat naskhi yang kurang rapi, namun masih jelas dibaca. Naskah memakai sampul warna biru tua. Penjilitan dilakukan ditengahtengah naskah. 


\section{[Tarekat Naqsyabandiyah]}

\author{
MS.TS/SC/PDG/45 \\ Kertas Eropa
}

\author{
Arab - Minang \\ $18 \times 25 \mathrm{~cm}$
}

Prosa

$76 \mathrm{hlm}$

\section{Asal Naskah}

Masjid Syeikh Muhammad Sa'id Bonjol

\section{Pengarang/Penyalin}

Anonim

\section{Gambaran Isi}

Secara umum naskah berisi tentang uraian amalan dalam Tarekat Naqsyabandiyah, mengenai kaifiyah zikir, rabithah, nafi istbat dan penjelasan mengenai kalimat la ilaha illallahu yang merupakan zikir para salik dalam Tarekat Naqsyabandiyah. Sebagai diketahui, bahwa tarekat merupakan salah satu kearifan ilmu tasawuf, maka di dalam naskah Tarekat Naqsyabandi ini banyak ditemui ungkapanungkapan tasawuf sebagai upaya membangun argumen zikir dalam Tarekat Naqsyabandiyah. Dari uraian teks, dijumpai indikasi bahwa teks ini khusus dibaca bagi murid yang telah lanjut kajinya. Sebagai gambaran isi di sini dikemukakan salah satu ungkapan penulis mengenai kalimat la ilaha illallahu:

Ketahuilah olehmu hai tolan yang terang daripada Nur Nabi shallahu 'alaihi wa sallam bahwa tiada sampai engkau kepada tauhid yang sempurna itu melainkan dengan senantiasa engkau sebut kalimah la ilaha illallahu karena ialah selebih-lebih amal kemudian dari pada fardhu. Dan faedahnya tiada kuasa seorang menyatakan dia. Bermula tauhid itu rahasia yang tersembunyi tempatnya nyatanya itu kalimat la ilaha illallahu. Maka mafhum dari pada ini bahwasanya kalimat itu perbendaharaan tauhid, karena itulah tiada sampai seseorang kepada Haq ta'ala melainkan dengan dia. Maka jangan engkau lupa dari pada menyebut kalimat itu pada hari-hari dan malam padahal engkau duduk atau berdiri 
engkau atau berjalan engkau sama engkau berdiri sembahyang atau tiada, maka mudah-mudah sampai engkau kepada Haq ta'ala. Sya'ir Badawi:

la ilaha illallahu ambil tolan

ialah nur menerangkan jalan

apabila zhahir dari pada milan

maka dapatlah ghaib kau kolan

Dan lagi pula ketika menyebut kalimat itu jangan lalai engkau akan maknanya... (hal. 5).

\section{Gambaran Lain}

Mengenai tahun penulisan teks dapat di ketahui dari bagian akhir naskah (hal. 75) yaitu tanggal 19 Jumadil Akhir 1320 H (1898 M). Gambaran yang lain yang didapati mengenai teks yaitu ungkapan akhir naskah:

Di nagal (Indonesia: dikutip) dari pada kitab Tasawuf dan empat kitab yang masyhur yang digunakan oleh masyeikh (guru-guru besar) yang besar yang termasuk di dalam i'tiqad yang sempurna yaitu ahlussunnah wal jama'ah (hal. 75).

Dari informasi ini diketahui, bahwa isi naskah merupakan inti sari dari beberapa kitab Tasawuf dan 4 buah kitab terkenal yang digunakan oleh Syeikh-Syeikh besar dalam lingkungan mazhab Ahlussunnah wal Jama'ah. Namun disayangkan penulis tidak menyebutkan nama-nama kitab yang dirujuk ketika menyusun kitab ini.

Gambaran mengenai penyalin si "Mariya" terdapat pada cacatan bawah pada halaman terakhir yang ditulis kemudian dengan pensil.

\section{Kondisi Fisik}

Naskah dalam keadaan tidak utuh, beberapa halaman awal naskah hilang. Keadaan naskah sangat baik, sehingga memudahkan dalam mengidentifikasi isi. Naskah dijilid dengan menggunakan benang, yang dijahit pada bagian tepi naskah. Naskah memakai khat naskhi yang tergolong rapi dan mudah dibaca, namun tinta teks sudah mulai mengabur akibat usia kendati masih jelas dibaca. 


\section{[Tasawuf dan Fiqih]}

MS.TS/SC/PDG/46

Kertas Lokal

$$
\text { Arab - Minang }
$$

$17 \times 21$
Prosa

$10 \mathrm{hlm}$

\section{Asal Naskah}

Masjid Syeikh Muhammad Sa'id Bonjol

\section{Pengarang/Penyalin}

Anonim

\section{Gambaran Isi}

Naskah berisi dua topik pembahasan yang sengaja diperdekatkan untuk memberi kesan hubungan 2 macam bidang keilmuan tersebut. Teks pertama berisi tentang fiqih, yaitu kajian rukun shalat. Teks selanjutnya berisi tentang kajian tasawuf yang cukup mendalam, yaitu kajian ilmu ma'rifat yang tentunya dikaitkan dengan amalan shalat.

Mengenai rukun shalat dijelaskan dengan ilustrasi simbolik. Dipahami dari dari ilustrasi itu bahwa niat shalat itu terdiri dari tiga bahagian, yaitu Qashad (mengengaja), Ta'arrudh (menyebutkan jenis shalatnya) dan Ta'yin (menerangkan hukum shalatnya). Ketiga elemen niat ini ta'luk (berhubungan erat) pada kalimat Allahu Akbar (takbir), karena tempat niat itu memang pada takbir tersebut, yaitu antara huruf yang delapan. Kemudian pada pengucapan ini, ada dua pandangan mata bathin yaitu:

Pertama: Alam Ajsad, martabat segala tubuh, ujud di Tuhan, bernama Malik. Alamnya bernama mulk, artinya dipandang dimata kepala.

Kedua: Alam Insan, martabat segala manusia, ujud di Tuhan, bernama jami'. Alamnya bernama Insan (hal. 2).

Setelah menyebutkan rukun shalat dan menjelaskan makna-makna yang tersirat dari amalan tersebut. Kemudian penulis menguraikan panjang lebar mengenai sisi tasawuf, dimulai dengan kajian Nur 
Muhammad. Mengenai hubungan shalat dengan Ma'rifat, penulis mengutip sebuah hadis yang diungkapkan penulis sebagai berikut: Karena inilah Sabda Nabi shallallahu 'alaihi wa sallam:

Artinya: Tiada sah sembahyang melainkan dengan Ma'rifat.

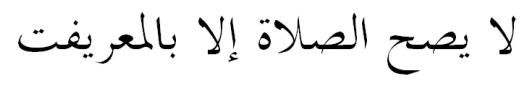
Maka Isyarat ma'rifat itu mengenal huruf Tajalli Tuhan. Dan mengenal itu istbat (hal. 8).

Selanjutnya, penulis menguraikan ilmu hakikat yang mendalam. Sangat pelik dipahami jika kita tidak mempunyai dasar akan ilmu ini, atau belum bertalaqgi dengan guru-guru yang mumpuni.

\section{Gambaran Lain}

Naskah ini berisi dua buah ilustrasi yang penuh simbolik dan maksud-maksud tertentu. Jika dilihat lebih lanjut maka naskah ini mempunyai kemiripan dengan pengajian Tubuh ala Tarekat Syathariyah.

\section{Kondisi Fisik}

Naskah dalam kondisi tidak tersusun rapi dan bercerai-cerai. Penjilidannya sudah rapuh, sehingga naskah tidak utuh lagi. Naskah yang ditulis tanpa menomoran halaman menyulitkan dalam menyusun kembali teks sesuai urutannya. Sebagian kertas naskah sudah robek karena tidak terawat. 


\section{[Tasawuf]}

MS.TS/SC/PDG/ 47

Melayu-Arab

Prosa

Kertas Lokal

$16 \mathrm{~cm} \times 21 \mathrm{~cm}$

$61 \mathrm{hlm}$

\section{Asal Naskah}

Masjid Syeikh Muhammad Sa'id Bonjol

\section{Pengarang/Penyalin}

\section{Anonim}

\section{Gambaran Isi}

Naskah merupakan kumpulan catatan-catatan mengenai kajian tasawuf yang cukup mendalam. Hal ini mengindikasi bahwa naskah ini merupakan catatan pribadi Syeikh sebagai pemilik naskah sebelumnya, mengingat teks campur aduk, tidak sesistematis naskah-naskah kitab umumnya.

Dalam teks ditemui kajian tasawuf mengenai kaji Nur Muhammad, catatan hari-hari baik dan beberapa tulisan mengenai tasawuf yang mirip dengan pengajian tubuh. Catatan-catatan ini berdedikasi mendalam, sehingga bagi pembaca yang belum mempunyai dasar keilmuan mengenai tasawuf, mungkin akan terjebak di antara ketidakpahaman bila membacanya secara serampangan.

Salah satu isi teks sebagai berikut:

Ilmunya sembilan umpanya:

Pertama, kerjaan (.....), kedua (...........) namanya, ketiga tergerakgerak tubuh nyawa namanya, keempat tetap tiada berhendak wujud namanya, kelima berhendak nafsu namanya, keenam kirakira hati namanya, ketujuh mengenal ma'rifat namanya, kedelapan mengesakan tauhid namanya, kesembilan percaya iman namanya (hal...). 


\section{Gambaran Lain}

Naskah disertai dengan ilustrasi berupa simbol-simbol atau ranjiranji dengan memakai tinta hitam dan biru. Sebagai catatan pribadi, naskah ini berindikasi bahwa penulisannya bersumber dari guru sipenulis sewaktu menuntut ilmu tasawuf.

\section{Kondisi Fisik}

Naskah dalam kondisi kurang terawat, beberapa halaman sudah lepas penjilidannya. Beberapa tulisan sudah banyak yang tidak bisa dibaca karena berlobang dimakan rayap. Naskah memakai khat riq'ah bercampur naskhi yang kurang rapi, sehingga agak sulit dibaca. Penomoran halaman dilakukan oleh penulis diatas teks setiap halamannya. Ukuran naskah tergolong kecil, sehingga bisa ditarok dalam saku. 


\begin{tabular}{ccc}
\multicolumn{3}{c}{ [Tasawuf, Fiqih, dan Tauhid] } \\
MS.TS/SC/PDG/48 & Melayu-Arab & Prosa \\
Kertas Eropa & $22 \times 18 \mathrm{~cm}$ & $178 \mathrm{hlm}$
\end{tabular}

\section{Asal Naskah}

Masjid Syeikh Muhammad Sa'id Bonjol

\section{Pengarang/Penyalin}

Anonim

\section{Gambaran Isi}

Isi berisikan tentang tasawuf yang mana berbicara tentang mengenal Tuhan, dengan cara mencapai tingkat ma'rifat melalui jalannya (tarekat). Dapat dinyatakan secara pasti, bahwa banyak bagian naskah yang hilang akibat terabaikan, sehingga menyulitkan dalam mengambarkan isi naskah. Lembaran-lembaran yang ada hanya menyebut kajian-kajian keilmuan tersebut dengan teks yang terpotong-potong akibatnya isi naskah juga tidak utuh.

\section{Kondisi Fisik}

Naskah dalam kondisi tidak terawat. Lembaran-lembarannya sudah terpisah-pisah sehingga sulit untuk disusun menurut urutan semestinya, ditambah naskah tidak memakai penomoran halaman. Ada beberapa bagian naskah yang telah tersobek. 


\begin{tabular}{ccc}
\multicolumn{3}{c}{ ljazah Tarekat Naqsyabandiyah } \\
MS.TS/SC/PDG/49 & Melayu-Arab & Prosa \\
Kertas Lokal & $22 \times 18 \mathrm{~cm}$ & $4 \mathrm{hlm}$
\end{tabular}

\section{Asal Naskah}

Masjid Syeikh Muhammad Sa'id Bonjol

\section{Pengarang/Penyalin}

Syeikh an-Naqsyabandi Natal

\section{Gambaran Isi}

Isinya berkenaan dengan tanda diangkatnya sang murid menjadi khalifah dalam Tarekat Naqsyabandiyah. Sebagaimana dalam Tarekat Naqsyabandiyah sendiri seorang salik diberi ijazah, dan yang satu lagi diberi surat ijazah. Pemberian ijazah maksudnya guru telah mengizinkan murid untuk mengamalkan Tarekat Naqsyabandiyah dan bersuluk (lazimnya 40 hari). Sedangkan pemberian surat ijazah maksudnya adalah berhasilnya murid dalam menjalankan amalan suluk-nya dengan mencapai maqam khalifah disisi Tarekat Naqsyabandiyah, maka ditulislah selembar surat ijazah sebagai petanda sang murid telah diangkat menjadi badal Syeikh tersebut.

Naskah ijazah Tarekat ini berisi tentang nasihat-nasihat Syeikh kepada si murid dalam bahasa Arab. Kebanyakan berisi tentang peringatan untuk selalu memasang Rabithah mursyid di manapun murid berada.

\section{Gambaran Lain}

Di samping menyebutkan Syeikh yang menulis surat ijazah, diakhir naskah juga ditemui cap stempel Syeikh sebagaimana lazimnya para mursyid tarekat di daerah lainnya di Minangkabau.

Sampai akhir abad ke-20, penulisan surat ijazah Tarekat masih ada ditulis dengan tangan oleh Syeikh itu sendiri. Namun akhir-akhir 
ini ada trobosan baru di kalangan guru tarekat menulis surat ijazah dengan bahasa melayu beraksara Arab atau beraksara Latin, sebab banyak dikalangan murid yang tak paham lagi bahasa Arab, tidak seperti dulu. Biasanya diatas lembar ijazah tersebut dikutip QS alJinn ayat 18 dengan seruan:"Barangsiapa atas nama tarekat niscaya akan kami tuangi deangan air mata ma'rifat".

Sebenar di abad ke 19 dan abad-abad sebelumnya, pemberian surat ijazah tak hanya dalam bidang tarekat. Dalam bidang fiqih, tauhid dan tasawuf pun dibuat surat ijazahnya bila muridnya telah dianggap sukses. Misalnya, bila seorang murid menamatkan kitab Shahih Bukhari, maka si guru pun akan menulis surat ijazah lengkap dengan mata rantai (silsilah) sampai kepada pengarang kitab itu. Sebab itu, ilmu di masa itu memang lekat di hati si murid, sehingga mereka menjadi alim yang kamil mukamal. Namun saat ini hal yang dianggap enteng itu telah diabaikan orang.

\section{Kondisi Fisik}

Naskah terdiri dari 1 lembar folio, dengan empat halaman. Dua halaman pertama berisi ljazah Tarekat, sedang dua halaman terakhir kosong. Naskah dalam kondisi yang cukup baik. Naskah ditulis dengan khat riq'ah yang tidak rapi namun masih jelas dibaca. Tulisan-tulisan naskah ada juga yang tembus ke halaman belakangnya akibat lembab dan terabaikan. 


\section{Tarekat Naqsyabandiyah}

$\begin{array}{cccc}\text { MS.TS/SC/PDG/50 } & \text { Arab-Melayu } & \text { Prosa } & 19 \mathrm{hlm} . \\ \text { Kertas Eropa } & 21,5 \times 16 \mathrm{~cm} & 14 \times 10 \mathrm{~cm} & 15 \mathrm{baris} / \mathrm{h} / \mathrm{m}\end{array}$

\section{Asal Naskah}

Surau Lubuk Landur

\section{Pengarang/Penyalin}

Anonim

\section{Kondisi Fisik}

Kondisi naskah rusak; aksara sulit dibaca karena tinta melebar, lembar-lembar naskah terlepas dari jilidannya dan tidak tersusun menurut urutannya. Naskah ditulis dengan khat naskhi yang cukup rapi. Naskah disampul dengan karton manila berwarna merah, penyampulan ini tampak dilakukan kemudian setelah teks tidak utuh lagi.

\section{Gambaran Isi}

Naskah berisi tentang amalan dalam Tarekat Naqsabandiyah al-Khalidiyah. Teks terdiri beberapa pasal, setiap pasal dimulai dengan basmallah. Pembahasan yang terdapat dalam naskah ini dimulai dengan kaifiyat zikir Tarekat Naqsabandiyah, tawajjuh, khatam khawajakan, dan terakhir ditutup dengan doa tawajjuh yang disertai dengan terjemahan gantung dalam bahasa Melayu. Di antara transliterasi teksnya ialah:

Bismillahirrahmanirrahim. Inilah kaifiyat mengerjakan zikir atas Tarekat Naqsabadiyah Mujaddidiyah Khalidiyah, yaitu hendaklah duduk dengan air sembahyang di atas tempat suci, padahal menghadap kiblat dengan duduk tawarruk sebelah kiri supaya hampir pandang kepada hati sanubari... 


\section{Gambaran Lain}

Pada lembar kosong di akhir naskah terdapat coretan yang berisi tentang berbagai hal yang berkaitan dengan pengamalan Tarekat Naqsabandiyah, namun catatan ini tampak ditulis oleh orang berbeda, terlihat dari jenis tulisan yang juga berbeda. Di antara catatan pada lembar kosong itu mengenai doa yang dibaca salik dalam hati ketika selesai ber-tawajuh. 


\section{Minhajul 'Abidin Melayu}

$\begin{array}{cccc}\text { MS.TS/SC/PDG/51 } & \text { Arab-Melayu } & \text { Prosa } & 140 \mathrm{hlm} . \\ \text { Kertas Eropa } & 23,5 \times 17 \mathrm{~cm} & 16 \times 10 \mathrm{~cm} & 26 \text { baris } / \mathrm{hlm}\end{array}$

\section{Asal Naskah}

Surau Lubuk Landur

\section{Penulis Teks Asal:}

Hujjatul Islam Abu Hamid Muhammad bin Muhammad bin Muhammad al-Ghadzali at-Tusi (Imam al-Ghazali)

\section{Penerjemah ke dalam bahasa Melayu:}

Syeikh Daud bin Abdullah al-Jawi al-Fathani

\section{Kolofon:}

Kolofon naskah terletak 2 halaman sebelum akhir teks. Pada kolofon disebutkan: Tanbih, hai segala saudara kami orang yang membaca dan melihat akan terjemah ini, manakala engkau dapat akan perkataan yang di dalam terjemah ini "kata" atau "aku kata" atau "kata Syeikh kami"atau "tilik kami"atau umpamanya, maka kata sekalian itu daripada perkataan imam Hujjatul Islam wal Muslimin, yaitu mu'allif asal terjemah ini, yaitu Sayyidi Muhammad al-Ghadzali at-Thusi radhiyallahu 'anhu wa nafa'ana bi ulumihi wa amaddana bi maddadihi wa askanahu bi rahmatihi wa ridhwanin Amin ya Rabbal 'Alamin.

Dan telah selesai kami menterjemahkan terjemah Minhajul 'Abidin ini dengan berlumur dengan taqshirnya dan dengan kurang adanya bagi kalam al-'Arif billahi, serta sedikit ilmu dan amal fagir dan hagir Daud bin Abdullah al-Jawi al-Fathani ghafarallahu lahu wa walidaihi wa ahzanihi al-muslimin maghfiratan 'ammatan, pada hari Jum'at qabil Jum'at lima belas hari, bulan Jumadil Akhir, pada negeri Mekkah Muhammiyah, Syarrafahallahu Ta'ala, pada hijrah alaihi afdhalus shalah wa azkat taslim, seribu dua ratus empat puluh. 


\section{Gambaran Isi}

Naskah berisi tentang kajian tasawuf bagi pemula. Penuturan di dalam teks cukup rinci dan mendalam. Dimulai dengan menjelaskan kedudukan ilmu dan amal shaleh, kemudian tahap-tahap yang ditempuh oleh seorang ahli ibadah hingga sampai ke hadirat Allah. Adapun sistematika penulisannya yaitu: (1) tahapan ilmu ma'rifat; (2) aqabah taubat; (3) aqabah awa'ik (godaan), mencakup dunia, nafsu, dan setan; (4) tahapan pendorong, dan penjelasan tentang bersyukur kepada Allah.

Di akhir teks, terdapat doa mujarrab berupa tambahan yang dinaql oleh Syeikh Daud bin Abdullah dan tidak terdapat pada teks asli Minhajul 'Abidin. 


\section{[Tasawuf (Nur Muhammad), Fiqih, dan Mantera}

$\begin{array}{cccc}\text { MS.TS/SC/PDG/52 } & \text { Arab-Melayu } & \text { Prosa } & 100 \mathrm{hlm} . \\ \text { Kertas Eropa } & 17 \times 11,5 \mathrm{~cm} & 12 \times 8 \mathrm{~cm} & 11 \mathrm{baris} / \mathrm{hlm}\end{array}$

\section{Asal Naskah}

Surau Lubuk Landur

\section{Pengarang/Penyalin}

Anonim

\section{Gambaran Isi}

Naskah ini berisi beraneka ragam kajian yang tampak tidak disusun secara sistematis. Bagian pertama, dan yang paling mendominasi, berisi tentang kajian ajaran tasawuf yang cukup mendalam, tampak dikhusus untuk kalangan muntahi, di antaranya mengenai Nur Muhammad dan asal penciptaan makhluk. Selanjutnya, terdapat mantera-mantera yang tampak kental dengan pengaruh Islam. Di antara pengaruh yang kentara dalam mantera-mantera yang dipaparkan dalam naskah ini ialah setiap akhirnya selalu diakhiri dengan perkataan "barokat Laa Illaha Illallah" di samping penggunaan diksi-diksi Arab. Bagian selanjutnya, yang paling sedikit, berbicara mengenai Fiqih ibadah, di antaranya mengenai rukun sembahyaang yang tiga belas.

\section{Kondisi Fisik}

Naskah dalam kondisi baik; baik kertas maupun susunannya masih utuh meski tidak lengkap karena lembar awal dan akhir naskah yang hilang. Aksaranya dapat dibaca dengan jelas, ditulis dengan jenis khat naskhi yang tidak rapi sehingga cukup sulit dibaca. Sampul naskah berupa karton merah, penyampulan dipastikan baru dilakukan oleh pemiliknya. 


\section{Gambaran Lain}

Isi teks tampak berkaitan dengan tasawuf muntahi atau yang dikenal dengan istillah tasawuf falsafi karena kajian dan cara pemaparannya penuh dengan ide dan simbol filsafat. Dalam teks juga ditemukan pengutipan ungkapan-ungkapan tokoh tasawuf falsati, seperti Muhyiddin Ibn 'Arabi. 


\section{Muwahib Rabbil Falaq Syarh Qashidah binti Milaq}

$\begin{array}{cccr}\text { MS.TS/SC/PDG/53 } & \text { Arab-Melayu } & \text { Prosa } & 38 \mathrm{hlm} . \\ \text { Kertas Lokal } & 21 \times 17,5 & 16 \times 13,5 & 19 \text { baris } / \mathrm{hlm}\end{array}$

\section{Asal Naskah}

Surau Lubuk Landur

\section{Penulis Matan Qashidah:}

Al-Qadhi Nashiruddin Ibn Bint Milaq as-Syazili

\section{Penulis Syarah:}

Syeikh Ahmad bin Ibrahim bin Alan an-Naqsyabandi

\section{Kolofon:}

Hadza kitab [haq] al-faqir ilallah ta'ala, Abdul Hakim ibn Abdullah alKhalidi Naqsabandi al-Mujaddidi, itaha.

Tammat al-kalam pada hari Jum'at pada bulan Rabi'ul Awal pada tahun dal..., tulisan saya faqir yang dha'if lagi bebal pandito Muhammad Shaleh ibn Malim Mangkuto, Kampung Situk, laras Ujung Gading, Luhak nan Tigo Luruh adanya. 


\section{Kaifiyat Membaca Qashidah Munfarijah}

$\begin{array}{cccc}\text { MS.TS/SC/PDG/54 } & \text { Arab-Melayu } & \text { Prosa } & 34 \mathrm{hlm} . \\ \text { Kertas Eropa } & 22 \times 15,5 & 13 \times 2,5 & 21 \mathrm{baris} / \mathrm{hlm}\end{array}$

\section{Asal Naskah}

Surau Lubuk Landur

\section{Pengarang/Penyalin}

Anonim

\section{Gambaran Isi}

Naskah berisi tentang kaifiyat pengamalan Qashidah Munfarijah. Qashidah merupakan kumpulan sajak-sajak (syair) dalam bahasa Arab. Kebiasaan ulama-ulama silam, khususnya sufi, menyusun doa dan wirid dalam bentuk syair atau qasidah, sebagai interpretasi jiwa sastra, kedekatan dengan keindahan dan yang Maha Indah, maka Qashidah Munfarijah merupakan salah satu wirid para ulama sufi yang disusun dalam bentuk syair.

Qasidah ini terdiri dari 50 bait. Dalam teks ini disertai dengan cara pengamalan wirid ini, tertulis di awal teks:

Maka inilah gambaran kaifiyat mengarajakan al-Munfarijah, meminta doa kepada Allah dan kepada Rasulullah (sebagai istighasah) tataala duka cita....

\section{Kondisi Fisik}

Naskah dalam kondisi baik; aksara dapat dibaca jelas, meskipun tulisannya tidak begitu rapi. Jenis khat yang digunakan naskhi, dengan tinta hitam yang tampak mulai mengabur. Penjilidan naskah memakai lem, penyampulan dengan karton manila berwarna merah. Penjilidan dan penyampulan tampak dilakukan pada waktu belakangan oleh pewaris naskah. 


\section{Gambaran Lain}

Teks awal Qashidah Munfarijah ditulis oleh salah seorang ulama terkemuka, yaitu Abi Fadhl Yusuf bin Muhammad bin YusufatTauzari, yang lebih dikenal dengan gelar Ibnu al-Nahwi (w. 513 H). Gambaran lengkap mengenai Qashidah ini dipaparkan dalam ensiklopedi karya-karya ulama klasik yang begitu terkenal, Kitab Kasyfuz Zhunnun 'an Asamil Kutub wal Funun, Vol. II, mulai halaman 1346. Qashidah ini dicetak dalam kitab Dalail Khairat yang sangat populer di nusantara. 
[Wirid-Wirid, Silsilah Qadariyah dan Rifa'iyah, Tarekat Sayyid Yusuf]

$\begin{array}{cccc}\text { MS.TS/SC/PDG/55 } & \text { Arab-Melayu } & \text { Prosa } & 22 \mathrm{hlm} . \\ \text { Kertas Eropa } & 12,5 \times 10,3 & 13,5 \times 7,5 & 9 \text { baris } / \mathrm{hlm}\end{array}$

\section{Asal Naskah}

Surau Lubuk Landur

\section{Pengarang/Penyalin}

Anonim

\section{Kolofon}

Pada teks kedua terdapat kolofon yang memberikan informasi penting mengenai pribadi penulis atau penyalin teks ini, yaitu: Sekarang hijrah Nabi Shallallahu 'alaihi wa sallam 1187 sanah, pada tahun Alif, pada bulan Rabi'ul Akhir, dalam 12 hari bulan, pada masa itulah ... (tulisan dicoret), tammat surat ini pada naskhahnya. Wallahu a'lam.

Hijrah Nabi Shallallahu 'alaihi wa sallam 1189 sanah pada tahun Dal, akhirah dalam dua puluh hari, bulan Dzul Qo'idah, pada hari Isnain, pada masa itulah Labai Mu'allim mengambil "wadha" dari pada gurunya Tuan Khalifah yang duduk dalam Bandar Natar (?) yang memegang hukum segala anak Aceh, Qadhi oleh Bada Mu'allim. Tammat Kalam.

\section{Gambaran Isi}

Naskah terdiri dari 3 teks. Teks pertama diidentifikasi sebagai wirid-wirid, berupa potongan ayat-ayat Al-Qur'an yang disusun sedemikian rupa. Dalam istilah ilmu hikmah, wirid ini dikenal dengan istilah "Ayat Lima Belas".

Teks kedua berisi tentang sebuah silsilah, namun tidak utuh, sebab terdapat halaman yang hilang. Pada bagian akhir silsilah tersebut dituliskan 2 nama tarekat yang menjadi nisbah silsilah, yaitu Tarekat 
Qadiriyah dan Tarekat Rifa'iyah. Mengakhiri silsilah, tertulis kalimat informatif: Syahr Jumadil Awal Tarikh tsamaniyah sanah $1184 \mathrm{H}$.

Teks ketiga berupa kaifiyat pengamalan tarekat yang bersumber dari Sayyid Yusuf kepada Muhammad Amin. Kaifiyat tersebut terdiri dari bacaan hadiah pahala, tawassul kepada pemimpin para sufi dan sebuah rangkaian doa istighasah dalam bentuk sajak berbahasa Arab. Di antara tokoh sufi yang disebut ialah Syeikh arRifa'i dan Syeikh Abdul Qadir Jailani.

\section{Kondisi Fisik}

Naskah dalam kondisi baik; aksara dapat dibaca jelas, namun pada kertas terdapat bekas rembesan air, tapi tidak mengganggu teks. Terdapat 2 jenis khat yang digunakan dalam naskah, pertama nask $h i$ yang sangat rapi, selanjutnya khat farisi. Tinta yang digunakan berwarna hitam dengan merah sebagai rubrikasi. Naskah dijilid menggunakan benang di setiap kurasnya.

\section{Gambaran Lain}

Pada margin akhir teks kedua (silsilah) terdapat 2 buah cap stempel yang belum bisa diidentifikasi. Stempel tersebut berbentuk persegi enal, memakai tinta hitam.

Dari informsi kolofon, diketahui bahwa teks ini termasuk berusia tua, yaitu ditulis pada tahun 1187 Hijriyah, atau bertepatan dengan tahun 1176 Masehi. Dari angkat yang tersebut diketahui pula pada masa itu telah terdapat sufi-sufi yang intens dengan Tarekat Qadiriyah dan Tarekat Rifa'iyah di nusantara, tepatnya di negeri Minangkabau. 
Kaifiyat Mengerjakan Zikir atas Jalan Tarekat Naqsabandiyah Mujaddidiyah Khalidiyah

$\begin{array}{cccc}\text { MS.TS/SC/PDG/56 } & \text { Arab-Melayu } & \text { Prosa } & 48 \mathrm{hlm} \\ \text { Kertas Eropa } & 19,5 \times 15 & 13,5 \times 9,5 & 16 \text { baris } / \mathrm{hlm}\end{array}$

\section{Asal Naskah}

Surau Lubuk Landur

\section{Pengarang/Penyalin}

\section{Anonim}

\section{Gambaran Isi}

Naskah ini berisikan tentang kaifiyat mengerjakan zikir Tarekat Naqsabandiyah Mujaddidiyah al-Khalidiyah yang dimulai dengan tata cara mengerjakannya, seperti berwudhu, duduk di tempat yang suci dan duduk tawarruk diiringi oleh bacaan zikir beserta doa-doanya.

Dalam teks ini juga terdapat pemaparan rinci mengenai Rabithah guru, disebutkan:

Hendaklah kita hadirkan apa rupa Syeikh kita itu di hadapan kita seperti kelakuan waktu dianya tawajjuh kepada kita itu. Apabila telah hadirlah ia maka kita i'tikatkan masuknya ke dalam hati sanubari, maka bahwasannya yang demikian itulah yang dinamakan Rabithah yang menolakkan was-was.

\section{Kondisi Fisik}

Naskah dalam kondisi baik, namun pada bagian tepi kertas terdapat bekas rayap. Aksara jelas terbaca, jenis khat-nya ialah naskhi yang cukup rapi, tulisan memakai tinta hitam. Naskah dijilid memakai benang pada sisi kurasnya.

\section{Gambaran Lain}

Pada lembar terluar terdapat kertas biru yang tertempel pada naskah yang merupakan sebuah surat dari seorang anak kepada 
ayahnya. Jika dibaca tidak begitu jelas karena bagian yang terpotong itu namun di sana ada tersebut nama seseorang, yaitu ..... bin Abdullah Rawa (Rao pen.) yang pada masa ini berada di Negeri Mekkah dan Abdul Ghani bin tuan Abdussalam Aurkuning yang sekarang berada di Sasak (nama sebuah daerah di Pasaman). 
Al-'Urwatus Wusqa wa Silsilah al-Wali al-Atqa" Qutb arRabbani al-Arif as-Samadani Syeikhina wa Ustazina Syeikh Muhammad bin Abdul Karim as-Samman

$\begin{array}{cccc}\text { MS.TS/SC/PDG } / 57 & \text { Arab-Melayu } & \text { Prosa } & 10 \mathrm{hlm} . \\ \text { Kertas Eropa } & 21,5 \times 16 \mathrm{~cm} & 17 \times 13 \mathrm{~cm} & 11 \mathrm{baris} / \mathrm{h} / \mathrm{m} .\end{array}$

\section{Asal Naskah}

Surau Lubuk Landur

\section{Penulis/Penyalin}

Muhammad Shaleh bin Murid Rawa (Rao)

\section{Gambaran Isi}

Naskah berisi tentang silsilah Syeikh Muhammad bin Abdul Karim Saman, yang masyhur dengan nama Tarekat Samman. Dalam Mukaddimah teks ini disebutkan:

Fahadxi [hi] al-Urwatul Wusqa wa Silsilah Wali al-Atqa qutb ar-Rabbani al-'Arif Shamadani Syeikhina wa Ustadzina sayyid Syeikh Muhammad Ibn as-Syeikh Abdul Karim as-Saman, inilah peperangan yang teguh dan silsilah Wali yang takut akan Allah Qutb ar-Rabbani wal 'Arif asShamadani Syeikh kita dan guru kita Sayyid Syeikh Muhammad anak Syeikh Abdul Karim as-Samman nafa'anallahu bi ulumihi.

Setelah menguraikan silsilah, dilanjutkan dengan wirid dengan judul Iftitah.

\section{Kondisi Fisik}

Naskah dalam kondisi baik dan utuh. Pada halaman depan yang kosong terdapat sobekan, namun tidak mengganggu teks. Aksara jelas, tapi jenis khat naskhi-nya kurang rapi sehingga agak sulit dibaca. Hal ini diperparah dengan banyaknya kata-kata yang korup. Tinta yang digunakan berwarna hitam. Penjilidan dilakukan dengan benang pada setiap kurasnya. 


\section{Gambaran Lain}

Teks ini tampak memiliki kesamaan judul dan topik dengan karangan Syeikh Abdus al-Palimbani, yang juga membahas silsilah dan wirid Tarekat Saman. 


\section{[Silsilah Tarekat Naqsabandiyah]}

$\begin{array}{cccc}\text { MS.TS/SC/PDG/58 } & \text { Arab - Melayu } & \text { Prosa } & 25 \mathrm{hlm} . \\ \text { Kertas Eropa } & 16,5 \times 11,5 \mathrm{~cm} & 13,8 \times 9 \mathrm{~cm} & 11 \mathrm{baris} / \mathrm{hlm} .\end{array}$

\section{Asal Naskah}

Surau Lubuk Landur

\section{Pengarang/Penyalin}

Anonim

\section{Gambaran Isi}

Naskah in merupakan silsilah Tarekat Naqsabandiyah milik Syeikh Muhammad Amin Lubuk landur, pada akhir naskah dikatakan bahwasanya beliau mendapat ijazah dari Syeikh Abdurrahman bil Almarhum Syihabuddin yang merupakan murid dari Syeikh Muhammad Basyir Malin Bandaharo Lubuk landur dan juga dari Syeikh Muhammad Basir yang merupakan ayahanda dari Syeikh Muhammad Amin.

Setelah Basmallah dan shalawat, disebutkan nasihat pemberi ijazah berupa tuntunan untuk selalu bertakwa, menjaga diri dari perilaku tercela, dan tuntutan untuk senantiasa berpegang dengan pitua Ahli Tarekat Naqsabandiyah. Kemudian baru disebutrkan silsilah dari Syeikh pemberi ijazah hingga Rasulullah.

\section{Kondisi Fisik}

Naskah dalam kondisi rusak, beberapa bagian kertas telah habis oleh rayap sehingga mengganggu teks. Aksara jelas, dengan khat naskhi yang cukup rapi. Warna tinta hitam. Naskah dijilid dengan benang yang agak besar.

\section{Gambaran Lain}

Pada akhir naskah ini terdapat cap stempel Syeikh Muhammad Bashir Lubuk Landur. 


\section{[Silsilah Tarekat Naqqsabdiyah dan Tarikh Kehidupan Nabi Muhammad Shallallahu 'alaihi wa Sallam]}

$\begin{array}{cccc}\text { MS.TS/SC/PDG/59 } & \text { Arab - Melayu } & \text { Prosa } & 63 \mathrm{hlm} . \\ \text { Kertas Eropa } & 15,5 \times 10,5 \mathrm{~cm} & 13 \times 7 \mathrm{~cm} & 15 \mathrm{baris} / \mathrm{hlm} .\end{array}$

\section{Asal Naskah \\ Surau Lubuk Landur \\ Pengarang/Penyalin \\ Anonim}

\section{Gambaran Isi}

Naskah ini terdiri dari 2 teks berbeda. Teks pertama tentang silsilah Tarekat Naqsabandiyah al-Khalidiyah, menyangkut nasihat seorang Syeikh kepada muridnya berikut silsilah Tarekat Naqsabadiyah alKhalidiyah, menyangkut nasihat seorang Syeikh kepada muridnya berikut silsilah Syeikh pemberi ijazah hingga Rasulullah. Pada akhir teks ini terdapat informasi pemberian ijazah dari Syeikh Sulaiman Zuhdi:

Wa faqir (...) al-Misqin Sulaiman Zuhdi al-Khalidi al-Mujawir fi Makah al-Musyarrafah karramallahu ta'ala wa Azzamaha (...) Syahr Muharram sanah alf wa mi'atain wa sitta wa tsamain $(1286 \mathrm{H})$ man ditujahu alBaital 'Atiq.

Teks kedua mengenai sejarah hidup Nabi Muhammad, ditulis dalam bahasa Melayu. Teks ini tidak lengkap, banyak bagian yang hilang.

\section{Kondisi Fisik}

Naskah dalam keadaan baik, meski bagian tepi naskah ini telah robek dimakan usia. Teks ditulis dengan teks naskhi yang tergolong kurang rapi, tapi masih bisa dibaca. Teks memakai sampul kertas karton tebal berwarna coklat. Penjilidan naskah dengan benang di tengah kurasnya, namun sebagian lembar naskah lepas dari penjilidannya. 


\section{Gambaran Lain}

Pada teks silsilah terdapat 3 nama ulama Tarekat Naqsabandiyah, yaitu: (1) Syeikh Abdurrahman Bila Ibn al-Marhun Syihabuddin al-Khalidi Asahan; (2) Syeikh Muhammad Bashir Ibn al-Marhum Malim Bendaharo al-Khalidi Pasaman Lubuk Landur; dan (3) Syeikh Muhammad Amin Ibn al-Marhum Syeikh Muhammad Bashir Lubuk Landur. Pada bagian teks terdapat cap stempel dengan tulisan jelas "Syeikh Muhammad Bashir Lubuk Landur". 


\section{Inilah [Permulaan Mengambil] Tarekat Naqsabandiyah}

MS.TS/SC/PDG/60

Kertas Eropa

\section{Asal Naskah}

Surau Lubuk Landur

\section{Pengarang/Penyalin}

Anonim

\section{Gambaran Isi}

Naskah berisi tata cara mengambil Tarekat Naqsabandiyah. Pada awalnya, dimulai dengan mandi taubat setelah shalat Isya', shalat Hajat, dan proses pemba'itan. Sistematika penulisan dengan runtut. Setelah penjelasan tersebut, disusul dengan beberapa doa yang diamalkan penganut Tarekat Naqsabandiyah.

\section{Kondisi Fisik}

Naskah dalam kondisi rusak; keadaan kertas sudah rapuh, tulisan pada naskah sudah mengembang, beberapa teks hilang akibat rayap. Jenis khat yang digunakan ialah naskhi yang cukup rapi. Tinta berwarna hitam. Sampul naskah ialah kertas karton manila berwarna merah, penyampulan dilakukan belakangan oleh pewaris naskah.

\section{Gambaran Lain}

Pada bagian belakang naskah terdapat beberapa catatan doa yang tidak terkait dengan isi teks. Satu di antaranya ialah doa yang dibaca ketika menyahut azan, yang mempunyai faedah untuk mengobati mata yang kabur, transliterasinya:

Doa menjawab abang (azan) ketika mengucap asyhadu anna Muhammadar Rasulullah faedahnya ini pada mata kabur-kabur, dihapuskan dua ibu tangan pada biji mata, ini doanya. 


\section{Sullamul Mubtadi fi Ma'rifati Thariqil Muhtadi}

$\begin{array}{cccc}\text { MS.TS/SC/PDG/61 } & \text { Arab-Melayu } & \text { Prosa } & 40 \mathrm{hlm} . \\ \text { Kertas Eropa } & 24 \times 16,5 \mathrm{~cm} & 16 \times 9,5 \mathrm{~cm} & 26 \text { baris } / \mathrm{hlm} .\end{array}$

\section{Asal Naskah}

Surau Lubuk Landur

\section{Pengarang/Penyalin}

Anonim

\section{Kolofon}

Telah selesailah menyurat kitab ini pada hari Sabtu, pada akhir dari bulan Dzulqa'idah pada tahun seribu dua ratus tujuh puluh delapan tahun, pada Mekkah al-Musyarrafah menyurat dia, maka barangsiapa membaca dia jika ada salah minta tolong tambah.

\section{Gambaran Isi}

Naskah berisikan tuntunan dasar tentang keimanan. Bagian awal berupa pengetahuan akidah, dibuka dengan kalimat: Wajib atas tiap-tiap orang yang akil baligh masuk di dalam Islam dan tetap ia di dalamnya atas berkekalan selama-lamanya, dan melazimkan dirinya barang yang lazim atasnya daripada segala hukum.

Selanjutnya, diuraikan tentang pengucapan dua kalimat syahadat berikut syarat dan rukun pengucapannya. Teakhir mengenai hal inwal memelihara diri dari hal-hal yang merusak iman.

\section{Kondisi Fisik}

Naskah dalam keadaan baik; aksara dapat dibaca jelas. Jenis tulisan yang digunakan ialah naskhi yang tergolong rapi. Tinta yang digunakan berwarna hitam, dengan merah sebagai rubrikasi. Sampul berupa karton dan plastik berwarna merah, penyampulan dilakukan oleh pewaris belakangan. 


\section{Gambaran Lain}

Gambaran mengenai judul jelas disebutkan pada bagian luar naskah, dengan tulisan: Hadza al-Kitab Sullamul Mubtadi fi Ma'rifato Thariqil Muhtadi. Pemberian judul ini tampak dilakukan oleh penulis yang berbeda. 


\section{Fathul Arifin yaitu Bicara \\ Tarekat al-Qadiriyah an-Naqsabandiyah \\ MS.TS/SC/PDG/62 \\ Arab-Melayu \\ Prosa \\ Kertas Erops \\ $22 \times 15,5$ \\ $16,1 \times 10,5$}

\section{Asal Naskah}

Surau Lubuk Landur

\section{Penulis}

Tuan Syeikh Ahmad Khatib Sambas

\section{Penyalin}

Muhammad Ma'ruf Ibn Syeikh Abdullah al-Khatib al-Palimbani

\section{Kolofon}

Bagian teks yang mengandung informasi terdapat pada lembar judul naskah, disebutkan:

Telah selesai mencap risalah at-Tarekatal-Qadariyah an-Naqsabandiyah di negeri Singapura, di kampung Mesjid Sultan 'Ali al-Iskandar Syah, yaitu hamba dha'if at-Thullab Muhammad ma'ruf ibn Syeikh Abdullah al-Khatib al-Falimbani, beserta dengan al-Mukarram Incek Muhammad Siadin dan an-Akh Muhammad Yahya, yaitu kepada tarikh sembilan hari, bulan Jumadil Awal, sanah 1287.

\section{Gambaran Isi}

Naskah berisi tentang kaifiyat pengamalan Tarekat Qadiriyah wa Naqsabandiyah. Tarekat ini merupakan gabungan 2 tarekat besar, yaitu Qadiriyah yang di-nisbah-kan kepada Syeikh Abdul Qadir Jailani dan Naqsabandiyah yang di-nisbah-kan kepada Syeikh Baha'uddin Syah Naqsabandi. Pengamalan yang dominan dari tarekat ini ialah unsur-unsur dari Tarekat Qadiriyah.

Di dalam teks juga terdapat wirid dan doa penganut Tarekat ini. Ciri khas wiridnya ialah pembacaan hadiah pahala kepada pendiri Tarekat Qadiriyah dan Naqsabandiyah. Selain itu juga terdapat teks shalawat yang dibaca berulang-ulang. 


\section{Kondisi Fisik}

Naskah dalam keadaan baik. Aksara dapat dibaca jelas. Namun, bagian tepi naskah terdapat bekas rayap. Akan tetapi, hal ini tidak mengganggu teks. Naskah ini ditulis dengan khat naskhi yang cukup rapi dengan warna tinta hitam. Penjilidan dengan penggunaan benang sudah mulai rapuh, beberapa halaman lepas dari jilidnya. Sampul kertas berupa karton coklat tebal.

\section{Gambaran Lain}

Pada halaman awal terdapat tanda shahih, dalam artian teks telah diperiksa, baik kesalahan huruf atau kata. Tulisan pada tanda tersebut berbunyi: Shahih (telah sesuai dengan aslinya), Muhammad Ma'ruf Ibn Abdullah al-Khatib Palembang.

Risalah ini, untuk periode belakangan, dicetak dan disebarkan oleh para penganut tarekat ini, yang kebanyakan di Jawa. 


\section{Wasiat Maulana Syeikh Ibrahim al-Khalidi Kumpulan}

$\begin{array}{cccc}\text { MS.TS/SC/PDG/63 } & \text { Arab-Melayu } & \text { Prosa } & 1 \mathrm{hlm} . \\ \text { Kertas lokal } & 20,1 \times 15,3 \mathrm{~cm} & 15 \times 9,3 \mathrm{~cm} & 26 \mathrm{baris} / \mathrm{hlm} .\end{array}$

\section{Asal Naskah}

Surau Lubuk Landur

\section{Penulis}

Maulana Syeikh Ibrahim bin Fahati al-Khalidi Kumpulan

\section{Penyalin}

Syeikh Muhammad Husen Ibn Abd (...)

\section{Kolofon}

Inilah wasiat Sayyid Syeikh Ibrahim al-Khalidi Naqsabandi Kumpulan. Hendaklah diamalkan wasiat hamba itu dan diwasiatkan kepada siapa-siapa mengikut dia, demikianlah adanya. Muharrar (ditetapkan) fi yaum arba', 8 Jumadil Akhir (...)

\section{Gambaran Isi}

Sesuai dengan informasi pada kolofon, naskah ini berisi tentang wasiat-wasiat Syeikh Ibrahim Kumpulan kepada murid-muridnya dan khalayak umum. Wasiat ini terdiri dari beberapa poin di antaranya:

... dan lagi wasiat akan dia dengan memuliakan segala ulama dan segala fuqaha dan segala orang hafizh Al-Qur'an, dan dengan suci hati daripada dengki dan khianat, dan dengan murah tangan pada segala harta, dan manis muka, dan murah nafas pada segala kebajikan, dan sabar pada kesakitan, dan memaafkan kesalahan segala taulan, dan memuliakan segala mereka yang tua-tua, dan kasihan kepada mereka yang muda-muda, dan meni[ngga]lkan bertambah-tambah pada sekalian perkara, istimewa pula pada bicara i'tikat, dan menjauhkan tamak pada harta, dan hendaklah dan hendaklah berpedang menyampaikan barangmana hajat kepada Allah dan janganlah harap akan sampai kepada Allah melainkan pada jalan yang benar dan pada 
mengikut syari'at Rasulullah shallallahu 'alaihi wa sallam pada zhahir dan bathin....

\section{Kondisi Fisik}

Secara umum, naskah dalam kondisi baik, namun di bagian atas dan bawah naskah terdapat lubang akibat rayap sehingga menyebabkan sebagian tulisannya terpotong dan tidak bisa dibaca. Aksara yang digunakan cukup terang dengan kat riq'ah yang rapi. Tinta yang digunakan berwarna hitam. Naskah dilipat 2 beberapa lama sehingga terdapat bekas lipatan pada tengah teks.

\section{Gambaran Lain}

Pada bagian naskah ini terdapat dua buah cap stempel yang cukup jelas. Pertama ialah cap dari Syeikh Ibrahim Kumpulan sendiri dan yang kedua dari cap Syeikh Muhammad Bashir Lubuk Landur sebagai pemegang wasiat.

Maulana Syeikh Ibrahim al-Khalidi Kumpulan (w. 1914, dalam usia 150 tahun) merupakan salah seorang ulama terkemuka dalam Tarekat Naqsabandiyah yang mempunyai pengaruh luas. Muridmuridnya yang banyak menjadi ujung tombak penyebaran Tarekat Naqsabandiyah hingga ke Sumatera Utara. 
[ljazah Syeikh Muhammad Bashir Lubuk Landur dari Syeikh 'Ali Ridha Jabal Abi Qubais Mekkah] MS.TS/SC/PDG/64 Arab Prosa $8 \mathrm{hlm}$.

Kertas Eropa $20,1 \times 15,3 \mathrm{~cm}$

$15 \times 9,3 \mathrm{~cm}$

Baris/hlm

\section{Asal Naskah}

Surau Lubuk Landur

\section{Pengarang/Penyalin}

Anonim

\section{Gambaran Isi}

Naskah ini berisi tentang pemberian izin (ijazah) dari Syeikh 'Ali Ridha di Jabal Abi Qubais Mekah kepada Syeikh Muhammad Bashir Lubuk Landur untuk mengajarkan sekaligus menyebarkan Tarekat Naqsabandiyah.

Naskah dimulai dengan basmallah dan shalawat, kemudian dilanjutkan dengan nasihat-nasihat Syeikh 'Ali Ridha untuk selalu bersikap takwa dan berpegang teguh pada syari'at. Setelah itu disebutkan silsilah Tarekat Naqsabandiyah. Terakhir ditulis doa khatam dari Maulana Syeikh Dhiya'uddin.

\section{Kondisi Fisik}

Naskah dalam kondisi baik; aksara dapat dibaca dengan jelas. Jenis khat yang dipakai ialah naskhi dan riq'ah yang cukup rapi. Tinta yang digunakan berwarna hitam. Teks dibingkai dengan 1 garis hitam. Penjilidan dilakukan dengan benang di setiap kuras.

\section{Gambaran Lain}

Pada akhir teks terdapat informasi penulisan ijazah, yaitu pada bulan Syawal tahun $1268 \mathrm{H}$. Di samping itu juga terdapat cap stempel dari Syeikh ‘ali Ridha Jabal Abi Qubais. 


\section{[Penjelasan Tarekat Naqsyabandiyah]}

\section{MS.TS/SC/PDG/65}

Kertas lokal

\author{
Arab - Melayu \\ $23 \times 15,5$
}

Prosa

$4 \mathrm{hlm}$

\section{Asal Naskah}

Masjid Syeikh Muhammad Sa'id Bonjol

\section{Pengarang/Penyalin}

Anonim

\section{Gambaran Isi}

Naskah berisi tentang penjelasan tentang Tarekat Naqsyabandiyah yang berasal dari syara. Argumen yang dikemukakan penulis mematah khaim kaum muda yang menyatakan bahwa Tarekat Naqsyabandiyah itu bid'ah, tidak diperbuat rasul dan sahabat, apalagi oleh ulama-ulama shaleh.

Penulis menyebutkan, bahwa Tarekat Naqsyabandiyah itu berasal dari syara' dan diamalkan oleh para imam-imam shalihin. Ini diungkapkan sebagai berikut:

Ketahui olehmu wahai saudaraku bahwasanya amal tarekat ini ada berasal dari syara' yaitu diperbuat oleh nabi dan sahabat dan shalihin dan salaf as-shalihin... (hal. 1).

Kemudian di dalam teks disebutkan kebenaran Tarekat Naqsyabandiyah diamalkan di seluruh negara Islam sejak dahulunya:

Maka ketahuilah olehmu segala saudaraku bahwasanya tarekat ahli suffiyah itu ialah jalan anbiya'auliya dan jalan orang-orang muqqarabin, orang-orang muttaqindan, dan orang shalihin. Dan janganlah dipermudah-mudah (.......) kita kepada Allah Ta'ala. Dan Tarekat Naqsyabandiyah jalan sufiyyah telah menjalani seluruh dunia, di Indonesia. Malaya, India, di seluruh dunia Islam.

[istimewa] di Mekkah al-musyarrafah fi (di) jabal qubais tempat melazimi adanya amin... (hal. 2). 


\section{Kondisi Fisik}

Naskah yang ditemui hanya dua lembar yang terpisah. Beberapa halaman belakang naskah sudah hilang. Naskah menggunakan khat naskhi yang cukup rapi, Namun karena tintany sudah tembus pada kertas, mengakibatkan tulisan susah di baca. 


\section{KOLEKSI SYOFYAN HADI (PADANG)}

\begin{tabular}{cccc}
\multicolumn{4}{c}{ Ilmu Segala Rahasia yang Halus dan Ajaib } \\
MS.TS/SH/PDG/ 01 & Arab-Melayu & Prosa & $204 \mathrm{hlm}$ \\
Kertas Lokal & $16 \times 22 \mathrm{~cm}$ & - & $10 \mathrm{baris} / \mathrm{hlm}$
\end{tabular}

\section{Asal Naskah}

Padang Kota

\section{Penulis}

Khalifah Rajab al-Khalidi

\section{Gambaran Isi}

Informasi tentang judul naskah ditemukan pada halaman awal, yaitu ilmu segala rahasia yang halus dan ajaib, yang ditulis oleh Khalifah Rajab al-Khalidi seorang penembang ajaran Tarekat Naqsyabandiyah di Solok Selatan. Sementara tahun penulisan naskah tidak ditemukan dalam teks.

Isi naskah tentang ajaran Tarekat Naqsyabandiyah al-Khalidiyah, terutama ajaran zikir latha'if serta beberapa kejadian dan peristiwa yang bersifat supranatural dan gaib yang akan ditemui seorang murid atau salik selama mengikuti ritual zikir, mulai dari proses bai'at hingga khatam tawajjuh.

Kutipan awal: bismillahirrahmanirrahim, inilah buku didalamnya akan ilmu segala rahasia-rahasia yang ajaib-ajaib dan yang halushalus yaitu pakaian segala nabi-nabi hingga samapi kepada umat seperti awliya' dan ulama-ulama yang besar-besar.

Kutipan akhir: kemudian munajat huwallahu [...] Tuhan yang wajib adanya mustahil tiadanya kemudian dimulai dengan fa'lam annahu afdhalu al-zikr la ialaha illahu dibuat tiga ratus kali sehari semalam.

\section{Kondisi Fisik}

Kondisi naskah masih cukup baik, tulisannya masih jelas terbaca teks ditulis dengan tinta hitam dan tanpa rubrikasi. Jilidannya masih bagus dan utuh. 


\section{[Ajaran Tarekat Naqsyabandiyah]}

$\begin{array}{cccc}\text { MS.TS/SH/PDG/02 } & \text { Arab - Melayu } & \text { Prosa } & 70 \mathrm{hlm} \\ \text { Kertas Lokal } & 16 \times 22 \mathrm{~cm} & - & 12 \mathrm{baris} / \mathrm{hlm}\end{array}$

\section{Asal Naskah}

Padang Kota

\section{Pengarang/Penyalin}

Khalifah Rajab al-Khalidi

\section{Gambaran Isi}

Informasi tentang judul naskah dan penulis tidak ditemukan pada teks. Sementara penulis naskah adalah Khalifah Rajab al-Khalidi ditulis 15 Rabiul Awal 1373. Khalifah Rajab al-Khalidi seorang adalah penembang ajaran Tarekat Naqsyabandiyah di Solok Selatan.

Isi naskah tentang ajaran Tarekat Naqsyabandiyah al-Khalidiyah dan segala prosesi ritual yang terdapat padanya sepeerti bai'at, rabithah, tawajjuh, zikir, dan khatam sebagai ritual terakhir dari ajaran Tarekat Naqsyabandiyah al-Khalidiyah.

Kutipan awal: bismillahirrahmanirrahim, ketahuilah olehmu bahwa inilah suatau ingatan peraturan adab Tarekat Naqsyabandiyah tatkala duduk ber-khatam dan tawajjuh, maka jika berbilang khalifahnya hendaklah duduk di kanan syeikh, tiga orang dan jika lebih tiga orang dudukan sbelah kiri syeikh.

Kutipan akhir: daripada sekalian muridnya lagi dha'if yaitu Khalifah Rajab bin Ya'qub orang Minang yang mempunyai taqshir bebal daripada sekalian pengetahuan dan tuntutan lagi karam di dalam lautan dosa.

\section{Kondisi Fisik}

Kondisi naskah masih cukup baik, tulisannya masih jelas terbaca teks ditulis dengan tinta hitam dan memiliki rubrikasi. Jilidannya masih bagus dan utuh. 


\section{Al-Tariqat an-Naqsyabandiyah al-Khalidiyah}

MS.TS/SH/PDG/03

Kertas Lokal

\author{
Arab - Melayu
}

$21 \times 16 \mathrm{~cm}$
Prosa

$175 \mathrm{hlm}$

15 baris/hlm

\section{Asal Naskah}

Solok

\section{Pengarang/Penyalin}

Khalifah Syeikh Ya'qub

\section{Gambaran Isi}

Judul naskah seperti terdapat pada bagian akhir teks adalah atThariqat an-Naqsyabandiyah al-Khalidiyah. Penulis naskah adalah Khalifah Syeikh Ya'qub (w. 1985). Naskah ini berasal dan ditulis di Madrasah Mujahadah Taram Batu Bajarang, Nagari Pauh Duo, Solok Selatan sebuah surau Tarekat Naqsyabandiyah. Pada halaman 60 dalam uraian tentang silsilah Tarekat Naqsyabandiyah, ditemukan informasi penulisan kitab ini yaitu tahun $1370 \mathrm{H}$. Jika dikonversi ke tahun Masehi mengikuti teori M.B. Lewis, maka penulisan naskah diperkirakan tahun $1951 \mathrm{M}$.

Naskah ini membicarakan ajaran pokok Tarekat Naqsyabandiyah, mulai dari ajaran dan paham Tarekat Naqsyabandiyah tentang peroses penciptaan alam sampai amalan-amalan zikir dan doa serta tata cara mengerjakannya. Namun demikian, pada jilid pertama naskah ini sedikit telah memberikan kemudahan dalam menggambarkan isinya, karena pada halaman sebelum pembahasan ide pokok tersebut dirincikan dengan cukup lugas dan sederhana.

Kutipan awal: Bismillahirrahmanirrahim, berkato Nabi shallallahu 'alihi wa sallam, man 'arafa nafsahu fa qad 'arafa rabbahu. "Barangsiapa mengenal akan dirinya sanggup mengenal akan Tuhannya...." 
Kutipan akhir: katanya kata Allah dianya telah menjadi Ahli Allah, perhatikan firman Allah, yadu Allahi fauqa aidihim, maksudnya kirakira tangan Allah di atas tangan mereka.

\section{Kondisi Fisik}

Kondisi naskah secara umum masih utuh, walaupun pada bagian atas sebelah kanan kertasnya berlubang sehingga tulisannya hilang. Jilidannya masih bagus dan utuh. Sampul berwarna coklat dengan kertas karton dan kulit pada bagian luar. 


\section{Ajaran Tarekat Naqsyabandiyah}

$\begin{array}{cccc}\text { MS.TS/SH/PDG/04 } & \text { Arab - Melayu } & \text { Prosa } & 16 \mathrm{hlm} \\ \text { Kertas Lokal } & 21 \times 16 \mathrm{~cm} & - & 20 \mathrm{baris} / \mathrm{hlm}\end{array}$

\section{Asal Naskah}

Payakumbuh

\section{Pengarang/Penyalin}

Maulana Syeikh Muhammad Salim Sikabu-kabu

\section{Gambaran Isi}

Judul naskah tidak ditemukan dalam teks. Sedangkan penulis naskah adalah Maulana Syeikh Muhammad Salim Sikabu kabu. Naskah ditulis pada tanggal 10 bulan shafar hari Rabu tahun 1350 $\mathrm{H}$.

Secara umum, naskah menguraikan kaifiyat pengamalan ajaran Tarekat Naqsyabandiyah secara utuh. Mulai dari zikir Ism al-zat, nafi wa Isbat, dan sebagainya hingga khatam. Juga menguraikan secara rinci bagain-bagian lathiafah yang ada dalam diri manusia.

Kutipan awal: Pasal nan pertama pada menyatakan Zikir Lathaif, Fa'lam mangko ketahuilah olehmu bahwasanya nafsu berlaku ia pada sekalian badan dan sekalian Lathaif seupama ia ta'rifkan sebagaimana ta'rifnya yang telah disebutkan di dalam Syaiyidi asSyeikh kabir murid Hikam al-salikin atas jalan orang yang berjalan. Kutipan akhir: Ditulis ini buku pada hari tanggal 10 hari bulan Shafar 1350 'arabiyah dengan seizin muallaf-nya. Ditulis oleh hamba faqih melacaklah isi adanya muallaf-nya al-Mursyidina wa maulana wa ustadzina Syeikhina Muhammad Salim sikabu-kabu adanya intahi.

\section{Kondisi Fisik}

Kondisi naskah secra umum masih baik dan utuh. Teks masih jelas terbaca dan teks ditulis dengan tinta hitam tanpa rubrikasi. disampul dengan kertas tebal dengan gambar bunga kecoklat- 
Bab 3: Koleksi \& Katalogisasi: Naskah Tasawuf di Propinsi Sumatera Barat

coklatan yang sudah lusuh. Tinta yang digunakan dalam menulis naskah yaitu tinta biru tanpa rublikasi, namun terdapat dua ilustrasi simbolis jalan zikir dalam amalan Tarekat Naqsyabandiyah. 


\section{Munajat Suluk}

MS.TS/SH/PDG/05

Kertas Lokal
Arab - Melayu

$15,5 \times 21 \mathrm{~cm}$
Prosa

$40 \mathrm{hlm}$

16 baris/hlm

\section{Asal Naskah}

Solok

\section{Pengarang/Penyalin}

Khalifah Rajab al-Khalidi

\section{Gambaran Isi}

Informasi tentang judul naskah, tahun penulisan dan tempat penulisan tidak ditemukan pada teks. Sementara penulis naskah adalah Khalifah Rajab al-Khalidi (w. 1956) kemudian naskah ini diwariskan kepada Khalifah Maimun (w. 1989) dan kemudian kepada Khatib Ruslan Batuah (Katik Sulan).

Isi naskah tentang tata cara munajat dan bacaanya yang diperuntukkan bagi pengikut Tarekat Naqsyabandiyah Kahldiyah, mulai munajat Subuh hingga munajat sebelum Fajar.

Kutipan awal: inilah tarhim yang dibaca sebelum Subuh, ya arhama alrahimin irhmana $2 x$, birahmatika biqudratika ya Allah, Ya arhama ar-rahimin irhamna $3 x$ birahmatika al-wasi'ah wa 'afina.

Kutipan akhir: dan jangan jadi imam pada kekuasaan orang lain dan jangan duduk seorang pada tikar rumah seorang hanya dengan izin tuan rumah itu, Ahmad. Muslim..

\section{Kondisi Fisik}

Kondisi naskah masih utuh dan cukup baik. Tulisannya masih jelas terbaca. Teks ditulis dengan tinta hitam dan memiliki rubrikasi. Jilidannya masih bagus dan utuh. 


\section{[Tauhid, Ibadah dan Zikir Tarekat Naqsyabandiyah]}

$\begin{array}{cccc}\text { MS.TS/SH/PDG/06 } & \text { Arab - Melayu } & \text { Prosa } & 54 \mathrm{hlm} \\ \text { Kertas Lokal } & 16 \times 21 \mathrm{~cm} & - & 18 \mathrm{baris} / \mathrm{hlm}\end{array}$

\section{Asal Naskah}

Solok

\section{Pengarang/Penyalin}

Khalifah Rajab al-Khalidi

\section{Gambaran Isi}

Informasi tentang judul naskah dan penulis tidak ditemukan pada teks. Sementara penulis naskah adalah Khalifah Rajab al-Khalidi ditulis 15 Rabiul Awal 1373. Khalifah Rajab al-Khalidi seorang adalah penembang ajaran Tarekat Naqsyabandiyah di Solok Selatan.

Isi naskah tentang ajaran tauhid Asyariyah dan ibadah yang bersifat syariah serta beberapa ajaran Tarekat Naqsyabandiyah alKhalidiyah dan segala prosesi ritual yang terdapat padanya seperti bai'at, rabithah, tawajjuh, zikir, dan khatam sebagai ritual terakhir dari ajaran Tarekat Naqsyabandiyah al-Khalidiyah. Teks dikemas dalam bentuk dialog dan tanya jawab anatara murid dan guru.

Kutipan awal: bismillahirrahmanirrahim, soal; apakah agama yang wajib kita pakai? Jawab; yaitu agama Islam. Soal; bagaimana yang dinamakan agama Islam? Jawab; yaitu segala hukum-hukum dan perintah-perintah Tuhan kita yang diturunkannya kepada nabi kita Muhammad SAW.

Kutipan akhir: artinya kita sucikan diri kita daripada dosa zhahir dan bathin supaya sempurna bulan ramadhan yang pahalanya yang amat besar itu, wallahu hadana wa hadakum wa nasharana wa nasharakum amin. 


\section{Kondisi Fisik}

Kondisi naskah kondisi naskah sudah tidak utuh, tujuh lembar pertama kertasnya berlubang di bagian bawah sehingga tulisannya hilang. Namun, tulisannya masih jelas terbaca. Teks ditulis dengan tinta hitam dan memiliki rubrikasi. Jilidannya masih bagus dan utuh serta cover berwarna biru. 


\section{Adab Tarekat Naqsabandiyah Berkhatam dan Tawajuh}

$\begin{array}{cccc}\text { MS.TS/SH/PDG/07 } & \text { Arab }- \text { Melayu } & \text { Prosa } & 60 \mathrm{hlm} \\ \text { Kertas Lokal } & 16 \times 21 \mathrm{~cm} & - & 24 \mathrm{baris} / \mathrm{hlm}\end{array}$

\section{Asal Naskah}

Solok

\section{Pengarang/Penyalin}

Khalifah Rajab al-Khalidi

\section{Gambaran Isi}

Informasi tentang judul naskah, tahun penulisan dan tempat penulisan tidak ditemukan pada teks. Sementara penulis naskah adalah Khalifah Rajab al-Khalidi (w. 1956). Naskah ini diwariskan kepada Khalifah Maimun (w. 1989) dan kemudian kepada Khatib Ruslan Batuah (Katik Sulan).

Isi naskah tentang tata cara ber-khatam tawajjuh yang merupakan salah satu fase ritual zikir dalam Tarekat Naqsyabandiyah. Khatam tawajjuh merupakan rangkaian terakhir dalam ajaran zikir Tarekat Naqsyabandiyah sebelum salik berpisah dari syeikhnya.

Kutipan awal: bismillahirrahmanirrahim, ketahui olehmu bahsanya inilah aturan dan peringatan adab tariqat Naqsyabandiyah tatkala duduk ber-khatam dan tawajjuh.

Kutipan akhir: wa tazhulluna fi zhilli al-'Arsy yawma laa zhilla illa zhilluhu, wa shallallahu 'ala sayyida Muhammad al-Nabiyi al-Ummiyi wa'ala Alihi wa shahbihi wa sallam.

\section{Kondisi Fisik}

Kondisi naskah kondisi naskah: naskah ini tidak utuh, pada bagian atas sebelah kanan kertasnya berlubang, sehingga tulisannya hilang. Jilidannya masih bagus dan utuh. Sampul berwarna biru dan terdapat ilustrasi. 


\section{[Adab Khalifah yang Memimpin Suluk]}

$\begin{array}{cccc}\text { MS.TS/SH/PDG/08 } & \text { Arab - Melayu } & \text { Prosa } & 24 \mathrm{hlm} \\ \text { Kertas Lokal } & 16,5 \times 21 \mathrm{~cm} & - & 12 \mathrm{baris} / \mathrm{hlm}\end{array}$

\section{Asal Naskah}

Solok

\section{Pengarang/Penyalin}

Khalifah Rajab al-Khalidi

\section{Gambaran Isi}

Informasi tentang judul naskah, tahun penulisan dan tempat penulisan tidak ditemukan pada teks. Sementara penulis naskah adalah Khalifah Rajab al-Khalidi (w. 1956), seorang syeikh Tarekat Naqsyabandiyah di Solok Selatan. Naskah ini diwariskan kepada Khalifah Maimun (w. 1989) dan kemudian kepada Khatib Ruslan Batuah (Katik Sulan).

Isi naskah tentang adab dan syarat seorang mursyid membimbing pada muridnya dalam berzikir dan ber-tawajjuh. Sebab, tidak semua syeikh, khalifah atau mursyid berhak memimpin suluk, kecuali setelah mememnuhi beberapa syarat dan ketentuan.

Kutipan awal: adab khalifah yang memegang suluk itu bahwa jangan ia tawajjuh-kan khalifah yang datang [....] duduk pada kanannya itu, maka jika ada yang datang itu saudara yang tua atau muda pun.

Kutipan akhir: man dakhala al-jami'ah yawma al-jum'ah fa shalla arba'a rak'atin qabla al-shlat aal-jum'ah yaqra'u fi kulli rak'atin alhamdulillah marrtan wa qul huwallau ahad dhamini marratan lam yamut hatta yara maq'adahu fi al-jannati aw yatara lahu..

\section{Kondisi Fisik}

Kondisi naskah secara umum masih utuh, walaupun pada bagian atas sebelah kanan kertasnya berlubang sehingga tulisannya hilang. Jilidannya masih bagus dan utuh. Sampul berwarna coklat. 


\section{Khabar Nazam Ushiyat}

$\begin{array}{cccc}\text { MS.TS/SH/PDG/09 } & \text { Arab - Melayu } & \text { Prosa } & 61 \mathrm{hlm} \\ \text { Kertas Lokal } & 21 \times 61 \mathrm{~cm} & - & 24 \mathrm{baris} / \mathrm{hlm}\end{array}$

\section{Asal Naskah}

Pasaman

\section{Pengarang/Penyalin}

Anonim

\section{Gambaran Isi}

Judul naskah adalah Khabar Nazam Ushiyat selesai ditulis pada hari arba'a 25 Jumadil Akhir tahun $1340 \mathrm{H}$. Namun demikian, informasi tentang penulis, penyalin dan tempat penulisan tidak ditemukan dalam teks.

Naskah ini Secara umum berisi tentang ajaran tasawuf akhlaqi, seperti cara yang tepat memahami takdir menurut ahl al-sunnah, tentang kematian, azab kubur, berbangkit, mahsyar, mizan, sirat, sorga dan neraka. Di dalamnya juga diuraikan tentang pembagian nafsu, rohani, dan hakikat zuhud terhadap dunia.

Kutipan awal: Aku mulai dengan bismillah, mengambil berkat kepada Allah, Apa dimaksud jangan ubah, begitu kata habib Allah al-rahma.

Kutipan akhir: Kalau salah meminta hormat, Kepada saudara kaum kerabat, Pada tahun 1340 sehari menulis, kalau salah perkataan handaklah kikis.

\section{Kondisi Fisik}

Kondisi naskah secara umum masih utuh, kondisinya dalam keadaan baik, walaupun pada bagian atas sebelah kanan kertasnya berlubang sehingga tulisannya hilang. Jilidannya masih bagus dan utuh. Teks ditulis dengan menggunakan tinta hitam tanpa rubrikasi. 


\section{Al-Manhal al-'Azb li Zikr al-Qalb}

MS.TS/SH/PDG/10

Kertas Eropa

Asal Naskah

Pasaman

\section{Pengarang/Penyalin}

Shaykh Isma'il al-Khalidi al-Minangkabawi
$61 \mathrm{hlm}$

$24 \mathrm{baris} / \mathrm{hlm}$

\section{Gambaran Isi :}

Judul naskah adalah al-manhal al-'adhb li-dhikr al-qalb dikarang oleh Shaykh Isma'il al-Khalidi al-Minangkabawi. Naskah selesai ditulis di rumah suluk Riau pada hari Selasa bertepatan dengan hari raya Idul fitri tahun $1245 \mathrm{H}$ atau sama dengan tahun $1819 \mathrm{M}$. Naskah adalah koleksi surau Mudiek Tampang Rao Pasaman.

Secara umum naskah MADQ berisi tentang ajaran tarekat Naqhsabandiyah Khalidiyah. Seperti rabithah, dhikr ithm al-dhat, dhikr nafyi ithbat, dhikr al-latha'if, adab suluk, adab ziarah mursyid, doa khatam, tawassul, tawajjuh, bagian-bagian lathifah dan sebagainya. Teks juga berisi celaan pengarang terhadap beberapa tokoh Tarekat Naqsyabandiyah cabang lainnya seperti tokoh Tarekat Naqsyabandiyah Muzhariyah dan Tarekat Naqsyabandiyah wa-Qadiriyah. Juga terdapat polemik antara pengarang dengan ulama-ulama asal Hadhramaut.

Kutipan awal: [qala] Syaykhuna rahimahu Allahu fi surati al-adabi wakadzalika al-wuqufu lazimun fi khatami Al-Qur'ani li-anna qira'ata al-'awami al-alfazu wa-qira'ata al-khawashshi ma'a tadabburi al-ma'ani wa-qira'ata akhashshi al-khawashshi tanbihu al-qalbi [wa]-tawjihuhu ila shahibi al-kalami wa-dzatihi al-muqaddasi jalla sha'nuhu ta'ala.

Kutipan akhir: Wa-jaza 'anna ya ilahi shaykhana * al-Khalidiya man bi-hi hadaytana. Dan balasi olehmu daripada kami hai Tuhan-ku 
akan Syeikh kami* yang terbangsakan kepada Mawlana Khalid yang dangan dia telah Engkau beri hidayah akan kami.

\section{Kondisi Fisik}

Kondisi naskah secara umum masih utuh, kondisinya dalam keadaan baik, walaupun ada beberapa halaman yang sudah hilang. Naskah juga tanpa cover dan jilidan sudah mulai rapuh. Teks ditulis dengan menggunakan tinta hitam tanpa rubrikasi. 


\section{Nazam Tarekat Naqsyabandiyah}

MS.TS/SH/PDG/11

Kertas Eropa

\author{
Arab - Melayu
}

$16 \times 21 \mathrm{~cm}$
$32 \mathrm{hlm}$

24 baris/hlm

\section{Asal Naskah}

Pesisir Selatan

\section{Pengarang/Penyalin}

Anonim

\section{Gambaran Isi}

Judul naskah, penulis, tahun penulisan dan tempat penulisan tidak ditemukan dalam teks.

Secara umum, naskah berisi tentang silsilah syeikh Tarekat Naqsyabandiyah mulai dari syeikh Baha' al-Din al-Naqsyabandiy pendiri ajaran tarekat ini hingga syeikh Isma'il al-Khalidi hingga syeikh-syeikh yang hidup setelahnya. Teks juga berisi beberapa zikir yang dibaca dalam khatam tawajjuh.

Kutipan awal: al-mursyid al-Kamil fi umm al-Qura, irsyaduhu fiha sara [...], al-mutawaffa jalisan muraqiban muntazhiran min rabbihi mawahibahu muntaqiyan [....] qabla thulu'i al-fajr.

Kutipan akhir: wa al-sakanati wa al-kalimati wa al-iradati wa alKhatharati min al-Zhununi. Dan pada segala diam dan pada segala kata dana pada segala kehendak pada segala keruhati daripada sangka.

\section{Kondisi Fisik}

Kondisi naskah sudah rusak, kertas sudah rapuh serta bagian pinggir yang sudah mendekati hancur. Beberapa teks yang bagian pinggir sudah hilang bersamaan dengan hialngnya kertas tersebut dimakan usia atau rayap. Naskah juga tanpa cover dan jilidan sudah mulai rapuh. Teks ditulis dengan menggunakan tinta hitam tanpa rubrikasi. 


\section{Lubb min Lubab 'Ilm al-Suluk}

$\begin{array}{cccc}\text { MS.TS/SH/PDG/12 } & \text { Arab } & \text { Prosa } & 13 \mathrm{hlm} \\ \text { Kertas Eropa } & 20,5 \times 17 \mathrm{~cm} & - & 10 \text { baris } / \mathrm{hlm}\end{array}$

\section{Asal Naskah}

Padang

\section{Pengarang/Penyalin}

Anonim

\section{Gambaran Isi}

Judul naskah seperti dicantumkan pada kolofon Lubb min lubab 'ilm al-suluk. Namun, tidak ditemukan informasi tentang penulis, tahun dan tempat penulisannya. Isi naskah tentang ajaran Tarekat Syattariyah, pembicraan dimulai dari maqam-maqam dalam tasawuf, tingkatan muraqabah makhluk kepada Khaliq hingga ajaran tentang martabat tujuh dan uraian tentang asal kejadian alam semesta serta proses penciptaannya oleh Allah. Kitab ini lebih banyak menyadur ajaran syeikh al-Burhanpuri dalam kitabnya Tuhfat al-Mursalah.

Kutipan awal teks: bismillahirrahmanirrahim, alhamdulillahi rabb al-'alamin, wa al-shalatu wa al-salamu 'ala rasulihi Muhammadin wa alihi wa shahbihi ajma'in, amma ba'du fa gad qala ghulamu rasulillah shallallahu 'alayhi wa sallama Muhammadun ibn al-Syaykh fadhlullah laqad iltafata sabiqan al-tuhfah al-mursalah ila al-nabi shallallahu 'alayhi wa salllama fi 'ilmi al-haqa'iq.

Kutipan akhir teks: li yadzhara lahu ma'ani kalami ahli al-wahdah li anna hadzihi al-qa'idati lubb min lubab 'ilmi al-suluk. Tammat wa Allahu allam bi al-shawab.

\section{Kondisi Fisik}

Kondisi masih baik dan bisa dibaca dengan jelas. Jilidannya juga masih baik. Naskah ditulis dengan tinta hitam dan merah pada rubrikasi. 


\section{Jawhar al-Haqa'iq}

$\begin{array}{cccc}\text { MS.TS/SH/PDG/13 } & \text { Arab -Melayu } & \text { Prosa } & 13 \mathrm{hlm} \\ \text { Kertas Eropa } & 20 \times 15 \mathrm{~cm} & - & 10 \mathrm{baris} / \mathrm{h} / \mathrm{m}\end{array}$

\section{Asal Naskah}

Padang

\section{Pengarang/Penyalin}

Anonim

\section{Gambaran Isi}

Judul naskah seperti terdapat pada halaman pertama Jawhar al-Haqa'iq. Namun infomasi tentang penulis, tempat dan tahun penulisan naskah tidak ditemukan dalam teks. Isi naskah tentang ajaran tarekat, pembicaraannya lebih spesifikasi tentang pembagian martabat atau tingkatan salik dalam mencari Tuhan. Pertama, disebut tingkatan mubtadi' (pemula), kedua disebut almutawassith (menengah) dan ketiga disebut tingkat al-muntahi (tingkat akhir). Masing-masing memiliki tata cara yang berbeda dalam ritual dan pemahaman akan Tuhan. Kitab ini merupakan Gambaran dari kitab al-Asma' al-Daqa'iq karangan Syams al-Din ibn Abi 'Abdillah.

Kutipan awal teks: bismillahirrahmanirrahim, alhamdulillahi alladzi ansya'a fi 'ilmihi awwalan 'aynan, wa-khalaqa arwahana tsaniyan ba'da khalqi nabiyina.

Kutipan akhir teks: karana bahwasanya apabila suci dan jernih segala hati diangkatkan dari padanya segala dinding dan segala tutup maka melihat dia akan...

\section{Kondisi Fisik}

Kondisi masih baik dan bisa dibaca dengan jelas. Naskah ditulis dengan tinta hitam tanpa ada rubrikasi. Diduga dalam naskah terdapat dua teks yang berbeda, di mana teks kedua yang menggunakan bahasa Melayu merupakan teks lain yang oleh kolektor dijilid bersamaan dengan teks Jawhar al-haqa'iq ini. 


\section{Ajaran Tarekat Naqsyabandiyah}
MS.TS/SH/PDG/14
Arab-Melayu
Prosa-Syair
$32 \mathrm{hlm}$
Kertas Lokal
$21 \times 16,5 \mathrm{~cm}$
24 baris/hlm

\section{Asal Naskah}

Payakumbuh

\section{Penulis}

Haji Abdul Wahid Ketinggian Sarilamak

\section{Gambaran Isi}

Judul naskah, tahun penulisan dan tempat penulisan tidak ditemukan dalam teks. Sedangkan penulias adalah Haji Abdul Wahid Ketinggian Sarilamak Secara umum naskah menguraikan kaifiyat pengamalan ajaran Tarekat Naqsyabandiyah secara utuh. Mulai dari zikir ism al-zat, nafi wa isbat, dan sebagainya. Juga menguraikan secara rinci prosesi suluk (khalwat) dalam istilah Tarekat Naqsyabandiyah al-Khalidiyah.

Kutipan awal: bismillahirrahmanirrahim, alhamdulillahilladzi hadana li hadza wa ma kunna linahtadiya law la an-Hadanallahu wa al-Shalatu wa al-salamu 'ala nabiyihi alladzi qala ta'liman lana..

Kutipan akhir: wa ma qara'ahu ahadun wa al-mukminin umuman wa al-muntasibina ila al-Tahriqah al-Naqsyabandiyah khushushan $f i$ afaqi al-'alam wa masyariqi al-ardhi.

\section{Kondisi Fisik}

Kondisi naskah secra umum masih baik dan utuh. Teks masih jelas terbaca dan teks ditulis dengan tinta hitam tanpa rubrikasi. 


\section{Ajaran Tarekat Saman}

MS.TS/SH/PDG/15

Kertas Lokal

\author{
Arab -Melayu
}

$16 \times 21 \mathrm{~cm}$
Prosa

$158 \mathrm{hlm}$

24 baris/hlm

\section{Asal Naskah}

Solok Selatan

\section{Pengarang/Penyalin}

Anonim

\section{Gambaran Isi}

Judul naskah, penulis tahun penulisan dan temapt penulisan tidak ditemukan dalam teks. Naskah dikoleksi oleh Khatib Munas (Katik Unan) seorang guru dan pengembang ajaran tarekat Saman di Solok Selatan Sumatera Barat.

Secara umum, naskah menguraikan ajaran tarekat Saman seperti tatacara berzikir, hakikat shalat, hakikat menghadapkan wajah kepada Allah SWT, dan seterusnya.

Kutipan awal: alhamdulillahi al-Hadi 'ala sabili al-Rasyad dan segala puji dan pujian bagi Allah yang menunjukkan kita atas jalan yang betul wa fi al-thariq al-tawfiq wa al-inayah dan yang menunjukkan kita kepada jalan taufik dan inayah.

Kutipan akhir: Allahumma ya daa'ima al-fadhli 'ala al-barriyah ya basiutha al-Yadayn bi al-'athiyah ya shahiba al-mawahib jalla 'ala sunnah Muhammad khira al-barriyah ighfir lana ya za al-'ula fi hazihi al-'asyiyah.

\section{Kondisi Fisik}

Kondisi naskah secara umum masih baik dan utuh walaupun naskah ini sudah tidak lengkap, bagian awal naskah beberapa lembarnya hilang. Dua lembar pertama, kertasnya berlobang dan juga pada bagian bawah sehingga ada beberapa huruf yang hilang. 


\section{Kitab Tasawuf}

$\begin{array}{cccc}\text { MS.TS/SH/PDG/16 } & \text { Arab -Melayu } & \text { Prosa } & 7 \mathrm{hlm} \\ \text { Kertas Lokal } & 14,5 \times 21 \mathrm{~cm} & - & 15 \mathrm{baris} / \mathrm{hlm}\end{array}$

\section{Asal Naskah}

Payakumbuh

\section{Penulis}

Datuk Mali Puti Alam Sarilamak Payakumbuh

\section{Gambaran Isi}

Judul, tempat dan tahun penulisan naskah tidak ditemukan dalam teks. Naskah ditulis oleh Datuk Mali Puti Alam Sarilamak Payakumbuh. Isi naskah tentang tasawuf yang memfokuskan uraiannya tentang ajaran tasawuf sunni terutama tentang penyucian hati melalui upaya zikir yang terstruktur dan terus menerus. Naskah menguraikan tentang hakikat ibadah seperti shalat, puasa dan seterusnya.

Kutipan awal teks: baapa nan sebenarnya sembahyang yaitu mehantarkan sambah kepada hak Allah ta'ala serta membesarkan nan disambah. Sebab ketiadaan makananya [.....] dalam zikir dipakai dalam sembahyang.

Kutipan akhir teks: beramal malamnya dengan shalat tarwih dan membaca Al-Qur'an al-Karim mudah-mudahan kita akan mendapat ramat dan ampunan serta kasih sayangnya amin ya rabb al-'alamin.

\section{Kondisi Fisik}

Kondisi naskah masih baik dan jilidannya masih rapi. Teks masih dalam kondisi baik dan jelas terbaca. Naskah ditulis dengan tinta hitam dan memiliki rubrikasi dengan tinta merah. 


\section{Ajaran Tarekat Naqsyabandiyah}
MS.TS/SH/PDG/17
Arab-Minang
Prosa-Syair
$32 \mathrm{hlm}$
Kertas Lokal
$21 \times 16,5 \mathrm{~cm}$
24 baris/hlm

\section{Asal Naskah}

Payakumbuh

\section{Penulis}

Haji Abdul Wahid Ketiggian Sarilamak

\section{Gambaran Isi}

Judul naskah, tahun penulisan dan tempat penulisan tidak ditemukan dalam teks. Sedangkan penulias adalah Haji Abdul Wahid Ketinggian Sarilamak Secara umum, naskah menguraikan kaifiyat pengamalan ajaran Tarekat Naqsyabandiyah secara utuh. Mulai dari zikir ism al-zat, nafi wa isbat, dan sebagainya. Juga menguraikan secara rinci prosesi suluk (khalwat) dalam istilah Tarekat Naqsyabandiyah al-Khalidiyah.

Kutipan awal: bismillahirrahmanirrahim, alhamdulillahilladzi hadana li hadza wa ma kunna linahtadiya law la an-Hadanallahu wa al-Shalatu wa al-salamu 'ala nabiyihi alladzi qala ta'liman lana..

Kutipan akhir: wa ma gara'ahu ahadun wa al-mukminin umuman wa al-muntasibina ila al-Tahriqah al-Naqsyabandiyah khushushan $f$ afaqi al-'alam wa masyariqi al-ardhi.

\section{Kondis Fisik:}

Kondisi naskah secra umum masih baik dan utuh. Teks masih jelas terbaca dan teks ditulis dengan tinta hitam tanpa rubrikasi. 


\section{[Ajaran Tarekat Naqsyabandiyah]}

$\begin{array}{cccc}\text { MS.TS/SH/PDG/18 } & \text { Arab - Melayu } & \text { Prosa } & 76 \mathrm{hlm} \\ \text { Kertas Eropa } & 18 \times 25 \mathrm{~cm} & - & 18 \mathrm{baris} / \mathrm{hlm}\end{array}$

\section{Asal Naskah}

Padang

\section{Pengarang/Penyalin}

Marya

\section{Gambaran Isi}

Judul naskah dan tempat penulisan ditemukan dalam teks. Namun ditemukan informasi tantang penyalin bernama Marya yang terdapat pada catatan akhir naskah. Mengenai tahun penulisan teks dapat di ketahui dari bagian akhir naskah (hal. 75) yaitu tanggal 19 jumadil akhir $1320 \mathrm{H}$ (1898 M).

Isi naskah tentang uraian amalan dalam Tarekat Naqsyabandiyah, mengenai kaifiyah zikir khafi, rabithah, zikir nafi istbat, dan penjelasan mengenai kalimat la ilaha illallahu yang merupakan zikir utama para salik dalam Tarekat Naqsyabandiyah.

Kutipan awal: Ketahuilah olehmu hai tolan yang terang daripada nur Nabi shallahu 'alaihi wa sallam bahwa tiada sampai engkau kepada tauhid yang sempurna itu melainkan dengan senantiasa engkau sebut kalimat la ilaha illallahu karena ialah selebih-lebih amal kemudian dari pada fardhu.

Kutipan akhir: Di naqal dari pada kitab Tasawuf dan empat kitab yang masyhur yang digunakan oleh masyeikh yang besar yang termasuk di dalam i'tiqad yang sempurna yaitu Ahlussunnah wal Jama'ah.

\section{Kondisi Fisik}

Kondisi naskah masih cukup baik, tulisannya masih jelas terbaca teks ditulis dengan tinta hitam dan tanpa rubrikasi. Namun demikian, 
diduga ada beberapa halaman awal naskah hilang. Naskah dijilid dengan menggunakan benang, yang dijahit pada bagian tepi naskah. Naskah ditulis menggunakan tinta hitam tanpa rubrikasi. 


\section{Fath al-'Arifin}

$\begin{array}{cccc}\text { MS.TS/SH/PDG/19 } & \text { Arab - Melayu } & \text { Prosa } & 29 \mathrm{hlm} \\ \text { Kertas Eropa } & 21 \times 17 \mathrm{~cm} & - & 16 \mathrm{baris} / \mathrm{hlm}\end{array}$

\section{Asal Naskah}

\section{Padang}

\section{Pengarang/Penyalin}

Syeikh Ahmad Khatib Sambas

\section{Gambaran Isi}

Judul naskah Fathu al-'Arifin, judul ini terdapat di kolofon pada halaman terakhir. Naskah ini adalah karangan syeikh Ahmad Khatib Sambas pendiri Tarekat Naqsyabandiyah wa-Qadiriyah. Informasi tentang tahun dan tempat penulisan teks tidak ditemukan dalam naskah.

Isi naskah tentang ajaran Tarekat Naqsyabandiyah wa Qadiriyah terutama tentang zikir dan segala aspek yang terakait dengannya. Kutipan awal: bismillahirrashman ar-rahim, artinya aku mulai dengan nama Allah memberi rahmat dan nikmat yang besar-besar lagi memberi rahmat dan nikmat yang [...] al-hamduliallahirabbil alamin.

Kutipan akhir: maka yaitu tawajjuh pada lathaif dan dua puluh daripada muraqabat dan bermula ini thariqat berhimpun padanya dua tarekat pertama qadiriyah yaitu zikir jahar keadaannya yang dan isbat dan kedua yaitu zikir khafi.

\section{Kondisi Fisik}

Kondisi naskah masih cukup baik, tulisannya masih jelas terbaca teks ditulis dengan tinta hitam dan tanpa rubrikasi. Jilidannya masih bagus. Naskah dikoleksi oleh Ali Muzakir yang merupakan dosen di IAIN Jambi. 


\section{Nahjat al-Salikin Wa bahjat al-Maslikin}

MS.TS/SH/PDG/20

Arab - Melayu

Prosa

$94 \mathrm{hlm}$

Kertas Lokal

$13 \times 22 \mathrm{~cm}$

19 baris/hlm

\section{Asal Naskah}

Padang Kota

\section{Pengarang/Penyalin}

Muhammad Husein Ibn Abdul Samad al-Khalidi

\section{Gambaran Isi}

Judul naskah Nahjat al-Salikin wa-bahjat al-Maslikin ditulis oleh Muhammad Husein bin Abdul Somad al-Khalidi pada tanggal 15 Zulqaidah tahun $1332 \mathrm{H}$. Isi naskah tentang ajaran Tarekat Naqsyabandiyah al-Khalidiyah seperti zikir dan berbagai ritualnya, maqam-maqam murid atau salik, syeikh yang kamil lagi mukammil serta informasi tentang penyebar ajaran Tarekat Naqsyabandiyah al-Khalidiyah di nusantara, yaitu Syeikh Isma'il al-Khalidi al-Jawi alMinangkabawi.

Kutipan awal: bismillahirrashman ar-rahim, wa shallallahu 'ala sayyidna wa 'ala alihi wa shahbihi wa sallam alhamdulillahi alladzi hadana li hadza wa maa kunna linahtadiya law la an- hadanallah. Kutipan akhir: kedua dengan nun muthlaqan, ketiga dengan tafshil tammat. Tarikh fi 15 zi al-qa'dah sanah 1332 bi qalam al-faqir Husaiyn bin Abd al-Shamad al-Khalidi Kajai.

\section{Kondisi Fisik}

Kondisi naskah masih cukup baik, tulisannya masih jelas terbaca teks ditulis dengan tinta hitam dan terdapat rubrikasi pada beberapa bagian. Jilidannya masih bagus. 


\section{[Kitab Tasawuf]}

$\begin{array}{cccc}\text { MS.TS/SH/PDG/21 } & \text { Arab - Melayu } & \text { Prosa } & 15 \mathrm{hlm} \\ \text { Kertas Eropa } & 21 \times 16 \mathrm{~cm} & - & 27 \mathrm{baris} / \mathrm{hlm}\end{array}$

\section{Asal Naskah}

Padang - Kota

\section{Pengarang/Penyalin}

Anonim

\section{Gambaran Isi}

Judul naskah tidak diketahui begitu juga tentang penulis, tahun dan tempat penulisannya. Isi naskah tentang ajaran tasawuf yang lebih berorientasi kepada tasawuf akhlaqi. Ajarannya lebih menekankan pembentukan sikap-sikap hidup mulia dan akhlak terpuji, seperti tidak rakus pada dunia, selalu menjaga diri dari aturan Allah, tidak menyakiti dan menzalimi hak orang lain sehingga sikap-sikap tersebut akan menjadikan manusia disukai orang lain dalam pergaulan dan kehidupan sehari-hari di tengah masyarakatnya.

Kutipan awal teks: baik kelakuannya dan pekertinya padanya dan tiada dlsyaratkan pada orang yang diambil akan sahabat mehabis ia akan segala sifat-sifat kamal dan melengkapi dia karena bahwasanya yang demikian itu membawa kepada kesukaran pada beroleh dia istimewa pada zaman kita ini.

Kutipan akir teks: dan mengetahui ia akan barang yang di dalam dirimu daripada diperoleh lubb, maka menghantarkan ia akan dia atasmu dalam setapah segala waktu dan sanya hendak.....akan mendirikan.

\section{Kondisi Fisik}

Kondisi masih baik dan bisa dibaca dengan jelas. Naskah ditulis dengan tinta hitam dan tidak terdapat rubrikasi. 


\section{[Kitab Ajaran Tasawuf]}

MS.TS/SH/PDG/22

Kertas Eropa
Arab

$21 \times 16 \mathrm{~cm}$
Prosa

$-$
$13 \mathrm{hlm}$

14 baris/hlm

\section{Asal Naskah}

Padang - Kota

\section{Pengarang/Penyalin}

Anonim

\section{Gambaran Isi}

Judul, informasi tentang penulis, tempat, dan tahun penulisan naskah tidak ditemukan dalam teks. Isi naskah tentang ajaran Tarekat Syattariyah yang mencakup Nur Muhammad sebagai asal dan awal penciptaan alam semesta, tentang kasab manusia, tentang melihat Tuhan di akhirat apakah jasmani atau rohani, apakah jin masuk sorga seperti manusia atau tidak, apakah orang kafir kekal di dalam neraka atau tidak, berikutnya tentang sifat dan zat Tuhan hingga ajaran martabat tujuh.

Kutipan awal teks: bismillahirrahmanirrahim, alhamdulillahi rabb al-'alamin, wa al-'aqibatu li al-mutaqin wa al-shalatu 'ala rasulihi Muhammadin wa 'ala alihi al-thaiyibin al-thahirin wa 'ala ashhabihi. amma ba'du, qala al-syaykh al-imam al-'alim al-zahid al-shafari radhiyallahu'anhu.

Kutipan akhir teks: fa fi qawli ibn 'ajil wa ghayrihi min ashhabihi tasma' da'wahu kama fi da'wa al-din ba'da tahlifi al-mudda'i 'alayhi idza wajada al-syahadah fi dzalika al-din.

\section{Kondisi Fisik}

Kondisi naskah secara umum masih baik, teks masih bisa dibaca dengan jelas, kecuali beberapa bagian yang sedikit agak kabur karena dimakan usia. Jilidannya masih baik. Naskah ditulis dengan tinta hitam dan merah sebagai rubrikasi. 


\section{[Kitab Tasawuf]}

MS.TS/SH/PDG/23

Kertas Eropa

$$
\text { Arab }
$$

$22 \times 15,5 \mathrm{~cm}$
Prosa

$-$
$13 \mathrm{hlm}$

17 baris/hlm

\section{Asal Naskah}

Padang - Kota

\section{Pengarang/Penyalin}

Anonim

\section{Gambaran Isi}

Judul, penulis, tempat, dan tahun penulisan naskah tidak ditemukan dalam teks. Isi naskah tentang ajaran tasawuf falsafi, meliputi: hakikat wujud alam semesta, wujud 'amm, dan wujud khashsh, a'yan kharijiyah dan a'yan tsabitah, pembagian ilmu kepada tashawwur dan tashdiq, dan bukti-bukti tentang wujud Allah SWT.

Kutipan awal teks: bismillahirrahmanirrahim, alhamdulillahi alladzi zahara bikasyifi suturatin wa-bathanin bi syadidi zuhurihi, wa alshalalatu wa al-salamu 'ala rasulihi Muhammadin miftah umurihi wa-'ala alihi wa-shahbihi ahli hamdihi wa-syukurihi.

Kutipan akhir teks: wa ghafala'an dzikrihial-ghafilun wa radhiyallahu 'an atshabihi ajma'in, wa man syabbahahum bi ihsanin ila yawmi aldin, wa Allahu a'lam.

\section{Kondisi Fisik}

Kondisi naskah sudah rusak, sebagian kertasnya sobek dan bolongbolong karena di makan usia ataupun rayap. Namun, teks yang masih tersisa dalam kondisi baik dan jelas terbaca. Naskah ditulis dengan tinta hitam dan memiliki rubrikasi dengan tinta merah. Jilidan naskah masih ada walaupun sudah sedikit mengalami kerusakan. 


\section{[Kitab Tasawuf]}

$\begin{array}{cccc}\text { MS.TS/SH/PDG/24 } & \text { Arab - Melayu } & \text { Prosa } & 14 \mathrm{hlm} \\ \text { Kertas Eropa } & 16,5 \times 21 \mathrm{~cm} & - & 14 \mathrm{baris} / \mathrm{hlm}\end{array}$

\section{Asal Naskah}

Padang - Kota

\section{Pengarang/Penyalin}

Anonim

\section{Deskrispi Isi:}

Judul, penulis, tempat, dan tahun penulisan naskah tidak ditemukan dalam teks. Isi naskah tentang tasawuf yang memfokoskan uraiannya tentang ajaran martabat tujuh, hakikat wujud Tuhan, hakikat Allah, hakikat Muhammadiyah, hakikat ma bihi al-syai'u huwa-huwa, hakikat Allah nur al-samawati wa al-ardh, dan seterusnya.

Kutipan awal teks: bismillahirrahmanirrahim, lillahi alladzi 'ala sabil al-rasyad, segala puji-pujian bagi Allah yang menunjuki kita jalan yang betul, wa fi al-thariq al-tawfiq wa al-inayah, dan menunjuki kita jalan taufik dan 'inayah, wa al-shalatu wa al-salamu 'ala man la nabiya ba'dahu.

Kutipan akhir teks: ta'yin dan zahurnya, kasannya itu wujudnya dan hakikatnya wa Allahu a'lam bi al-shawab al-marja' wa al-ma'ab, alhamdulilahi rabb al-'alamin.

\section{Kondisi Fisik}

Kondisi naskah masih baik dan jilidannya masih rapi. Teks masih dalam kondisi baik dan jelas terbaca. Naskah ditulis dengan tinta hitam dan memiliki rubrikasi dengan tinta merah. 


\section{Ijazah Tarekat Naqsyabandiyah}

MS.TS/SH/PDG/25

Arab

Prosa

$4 \mathrm{hlm}$

Kertas Lokal

$30 \times 21 \mathrm{~cm}$

15 baris $/ \mathrm{hlm}$

\section{Asal Naskah}

Padang - Kota

\section{Pengarang/Penyalin}

Syeikh al-Naqsyabandi Natal

\section{Gambaran Isi}

Judul naskah seperti disebutkan pada kolofon adalah ijazah Tarekat Naqsyabandiyah karangan Syeikh al-Naqsyabandi Natal. Namun, informasi tentang tahun dan tempat penulisan tidak ditemukan. Naskah Naskah terdiri dari 1 lembar folio, dengan empat halaman. Dua halaman pertama berisi ijazah tarekat, sedang dua halaman terakhir kosong. Naskah dalam kondisi yang cukup baik. Naskah ditulis dengan khat riq'ah yang tidak rapi namun masih jelas dibaca. Tulisan-tulisan naskah ada juga yang tembus ke halaman belakangnya akibat lembab dan terabaikan.

Isi naskah tentang tanda yang boleh diangkatnya sang murid menjadi khalifah dalam Tarekat Naqsyabandiyah. Sebagaimana dalam Tarekat Naqsyabandiyah sendiri seorang salik diberi ijazah, dan yang satu lagi diberi surat ijazah. Pemberian ijazah maksudnya guru telah mengizinkan murid untuk mengamalkan Tarekat Naqsyabandiyah dan bersuluk yang biasa dikerjakan selama 40 hari. 


\section{ljazah Tarekat Naqsyabandiyah}

$\begin{array}{cccc}\text { MS.TS/SH/PDG/26 } & \text { Arab - Melayu } & \text { Prosa } & 32 \mathrm{hlm} \\ \text { Kertas Lokal } & 21 \times 16,5 \mathrm{~cm} & - & 24 \mathrm{baris} / \mathrm{hlm}\end{array}$

\section{Asal Naskah}

Pesisir Selatan

\section{Pengarang/Penyalin}

Anonim

\section{Gambaran Isi}

Judul naskah, penulis, tahun penulisan dan tempat penulisan tidak ditemukan dalam teks. Secara umum, naskah MADQ berisi tentang ajaran Tarekat Naqsyabandiyah Khalidiyah. Seperti rabithah, dhikr ithm al-dhat, dhikr nafyi ithbat, dhikr al-latha'if, adab suluk, adab ziarah mursyid, doa khatam, tawassul, tawajjuh, bagian-bagian lathifah, dan sebagainya. Naskah juga menerangkan tentang kaifiyah (tata cara) amalan Tarekat Naqsyabandiyah. Setelah itu naskah menguraikan ijazah Tarekat Naqsyabandiyah dengan bahasa Arab, kemudian silsilah lengkap serta dibubuhi dengan stempel sang penulis (syeikh).

Kutipan awal: bismillahirrahmanirrahim, alhamdulillahirabbil alamin, ashshalatu wa al-salamu 'ala sayyidina Muhammadin wa 'ala Alihi wa shahbihi ajma'in. Inilah kaifiyat jalan mengamalkan zikirullah pada Tarekat Naqsyabandiyah.

Kutipan akhir: al-qa'im maqama syeikhihi abihi [....] pintik kayu ibn al-amrhum syeikh Abd al-Lathif 'afa 'anhuma Allahu.

\section{Kondisi Fisik}

Kondisi naskah secara umum masih utuh, kondisinya dalam keadaan baik walaupun ada beberapa halaman yang sudah hilang. Naskah juga tanpa cover dan jilidan sudah mulai rapuh. Teks ditulis dengan menggunakan tinta hitam tanpa rubrikasi. Naskah memakai sampul biru. 
Bab 3: Koleksi \& Katalogisasi: Naskah Tasawuf di Propinsi Sumatera Barat 


\section{4 \\ Kalehsi dan Katalogisasi \\ NASKAH TASAWUF DI PROPINSI SUMATERA UTARA "Koleksi Museum Negeri Medan"}

Oleh:

Ahmad Kholid Dawam dan Syarif

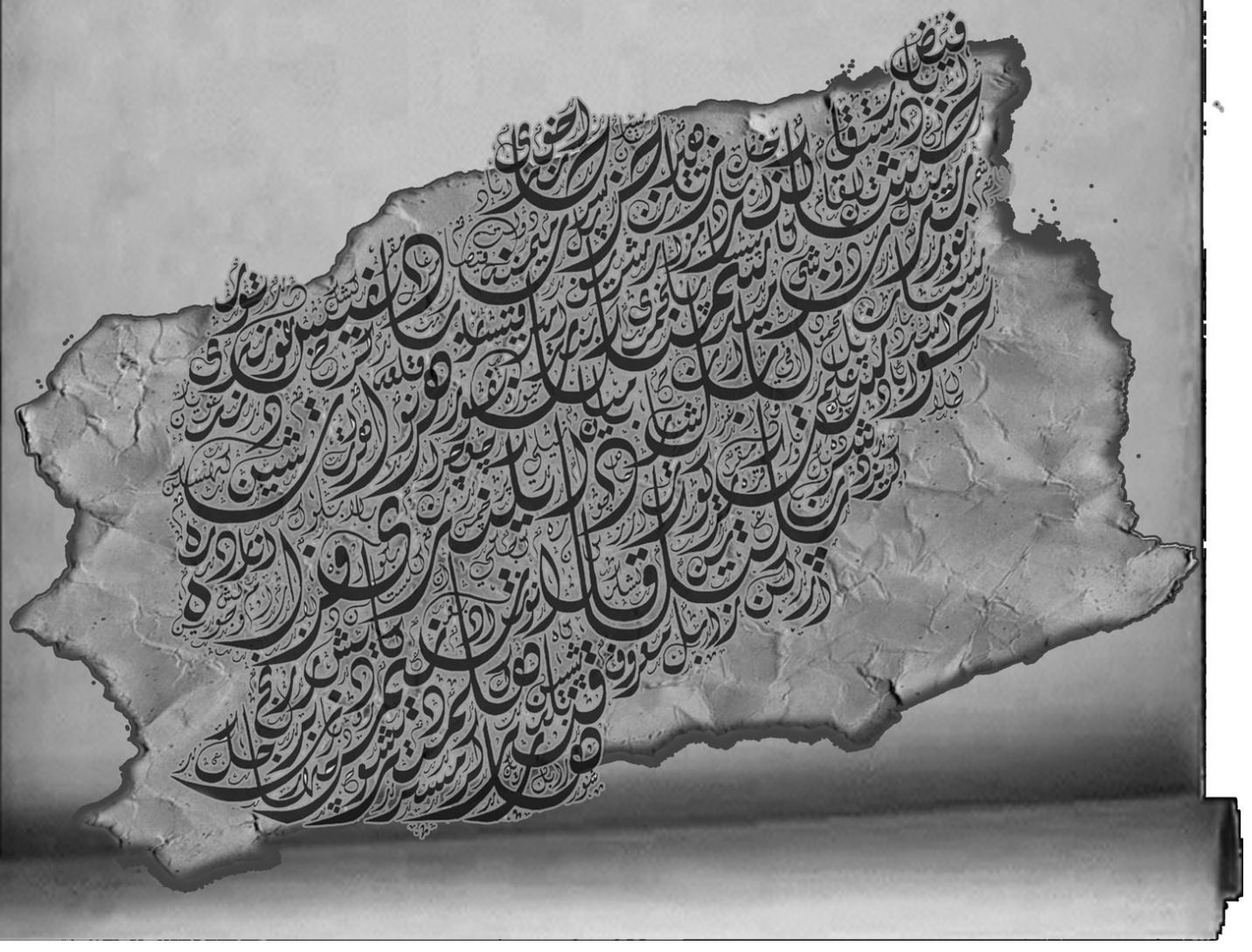




\section{Kasyf al-Faraib}
3170/Ts-1a/MNSU/2012
Arab \&Melayu
Prosa
$132 \mathrm{hlm}$
Kertas Eropa
$23 \times 16 \mathrm{~cm}$
$18 \times 11 \mathrm{~cm}$
19 baris/hlm

\section{Pengarang}

Anonim

\section{Penulisan}

Tidak ada

\section{Kolofon}

Tidak ada

\section{Cap Kertas/Watermark}

\section{Crescent}

\section{Gambaran Isi}

Menjelaskan tentang takdir, hikmah tahajjud, dan penguraikesulitan hidup serta aspek-aspek akhlak dan lainnya. Di penghujung teks ini juga terdapat syair-syair yang berkaitan dengan amaliah seharisehari sebagai bacaan doa penawar kesulitan hidup.

\section{Keterangan}

Awal teks: "Bermula rahmat Allah dan selamanya itu tertentu atas [...] yang menyatakan ia akan akan segala yang ajib. Ajib dan yang garib garib daripada ilmu hikmah dan ma'rifah..."

Akhir teks: "... adapun sembahyang magrib tiga rakaat itu karena kenyataan dan ke-Esa-an Tuhan itu tiga martabat sesuatu \{satu\} Ahadiyah kedua wahidah ketiga wahidiyah. Sesoal sembahyang Isya empat rakaat itu apa sebab pada kita maka jawabnya adapun sembahyang Isya itu empat rakaat karena kenyataan anak Adam itu empat martabat pertama wadi kedua madzi ketiga mani keempat manikam inilah kenyataan anak Adam itu. Tamma."

Kitab Kasyful Faraib ini adalah syarah dari kitab al-Munfarijah karya Abi Yahya Zainuddin Zakaria bin Muhammad bin Ahmad al-Anshari. 


\section{Dawaul Qulub min al-'Uyub}

$\begin{array}{cccc}\text { 3170/Ts-1b/MNSU/2012 } & \text { Arab \& Melayu } & \text { Prosa } & 132 \mathrm{hlm} \\ \text { Kertas Eropa } & 23 \times 16 \mathrm{~cm} & 18 \times 11 \mathrm{~cm} & 19 \mathrm{baris} / \mathrm{hlm}\end{array}$

\section{Pengarang}

Muhammad bin al-Khatib Langin

\section{Penulisan}

\section{Kolofon}

\section{Cap Kertas/Watermark}

\section{Crescent}

\section{Gambaran Isi}

Menjelaskan tentang adab mencari ilmu, adab seorang pengajar menghindari maksiat zahir dan batin, dan menghindari semua maksiat. Terdapat dialog antara Sayyidina 'Ali dengan sahabat tentang keutamaan ilmu.

Awal teks: "Bismillahi ar-rahmani ar-rahimi wabihi nasta'inu. Alhamdulillahi al-fatihi quluba awliya'ihi bi anwarihi. Segala pujipujian bagi Allah yang membuka ia akan segala hati wali-Nya dengan segala nur-Nya..."

Akhir teks: “... maka katanya karena aib tiada berlari-lari di belakang seteru dan berdiri ia hingga didapat oleh seteru akan dia dan bersuara ia pada tempat yang tiada patut bersuara maka memiliki akan kuda \{kode?\} oleh murid ibnu [...] maka tatkala ada itu pada arif [fa-ra-'ain]." 


\section{Diya al-Wara ila Suluki Thariqat al-Ma'budi al-'Ula}

$\begin{array}{cccc}\text { 3148/Ts-2a/MNSU/2012 } & \text { Arab \& Melayu } & \text { Prosa } & 198 \mathrm{hlm} \\ \text { Kertas Eropa } & 25 \times 18 \mathrm{~cm} & 17 \times 12 \mathrm{~cm} & 21 \mathrm{baris} / \mathrm{hlm}\end{array}$

\section{Pengarang}

Anonim

\section{Penulisan}

\section{Kolofon}

\section{Cap Kertas/Watermark}

Ada tetapi tidak jelas

\section{Gambaran Isi}

Menjelaskan tentang sifat munafik, tirakat, sifat-sifat hati, ridha dengan takdir, mengingat mati, dan akidah yang sahih.

\section{Keterangan}

Awal teks: "Bismillahi ar-rahmani ar-rahimi alhamdulillahi al-ladzi awjaba 'ala 'abdihi ta'ata ar-Rahmani. Segala puji bagi Allah yang mengwajib la atas hambanya akan taat bagi Tuhan yang bernama Rahman..."

Akhir teks: "... Allahumma ij'al al-hajata min kulli hajatin Allahumma ij'alal-barakata min kulli barakatin Allahumma ij'alas-salamata min kulli salamatin salamatan ila yaumi ad-din ya Rabbaal-'alamina wa sallallahu 'ala khayri khalkin Muhammadin wa 'alihi wa sahbihi wa sallamaamin amin. Tammat." 


\section{Al-Manhaj al-Atamm fi Tabwibi al-Hikam (Metode yang Lebih Sempurna dalam Pembukuan Kitab al-Hikam)}

3148/Ts-2b/MNSU/2012 Kertas Eropa
Arab \&Melayu

$25 \times 18 \mathrm{~cm}$
Prosa $198 \mathrm{hlm}$

$17 \times 12 \mathrm{~cm}$

21 baris/hlm

\section{Pengarang}

Ali bin Husamuddin al-Hindi

\section{Penulisan}

\section{Kolofon}

\section{Cap Kertas/Watermark}

Ada tetapi tidak jelas

\section{Gambaran Isi}

Menjelaskan tentang akhlak tasawuf, cara-cara mendekatkan diri kepada Allah dan berbagai hal yang ada dalam kitab al-Hikam karya Ibnu 'Athaillah as-Sakandari. Kitab ini merupakan ringkasan dan terjemah dari kitab al-Hikam.

\section{Keterangan}

Awal teks: "Bismillahi ar-rahmani ar-rahimi al-hamdulillahi almulhimi bisawabi al-kasyifi li 'ibadihi 'an wujuhi al-ma'ani sitranniqabi wa ash-shalatu wa as-salamu 'ala sayyidina wa rasulina Muhammadin shalla Allahu 'alayhi wa sallama khairi man 'utiya hikmatun wa fushshila al-khitabu wa 'ala 'alihi wa shahabihi al-ladzi hunna fi aqtari al-aradi fahuwa al-ma'aniya aqtabu..."

Akhir teks: ".. fa as'aluka ya Qaribu ya Mujibu 'ij'alna li azhamatika syahidina wa tahta hilali sultanika hamidina wa karimi janabika mutamassikina wa bika fihali masa 'ili syai'in birahmatika ya arhama ar-rahimina wa Allahu al-muwaffiqu tamma." 


\section{Naskah Tasawuf}

$\begin{array}{cccc}\text { 3148/Ts-2c/MNSU/2012 } & \text { Arab \& Melayu } & \text { Prosa } & 198 \mathrm{hlm} \\ \text { Kertas Eropa } & 25 \times 18 \mathrm{~cm} & 17 \times 12 \mathrm{~cm} & 21 \mathrm{baris} / \mathrm{hlm}\end{array}$

\section{Pengarang}

Anonim

\section{Penulisan}

\section{Kolofon}

\section{Cap Kertas/Watermark}

\section{Gambaran Isi}

Menjelaskan tentang alam manusia, alam ruh, nafsu, dan aspekaspek tarekat dan ma'rifat. Lalu pada akhirnya menjelaskan tentang keutamaanla ilaha illa Allah,zikir,dan juga silsilah tarekat.

\section{Keterangan}

Awal teks: "Bismillahi ar-rahmani ar-rahimi wabihi nasta'inu alhamdulillahi al-ladzi kasyafa al-fada 'an qulubi al-muhibbina wa ash-shalatu wa as-salamu 'ala sayyidina Muhammadin al-hadi lialmu'minina wa 'ala 'alihi ajma'ina. Dan dengan dia jua kami minta tolong pada karangan ini segala puji sabit bagi Allah Tuhan yang membukakan akan tutup daripada hati segala yang kasih dan rahmat dan salam atas penghulu kita Muhammad yang menunjuki jalan bagi segala mukmin dan atas segala keluarganya dan sahabatnya sekalian. Amin..."

Akhir teks: "... dan Tarekat Rifa'iyyah dan Tarekat Wafaiyyah dan Hafawiyyah dan Tarekat al-Ba'aliyah dan Tarekat Ratiniyah dan Tarekat Awaliyah, maka sekalian tarekat ini mutassil dengan kita. Allahumma at-tawfiqu nafa'a Allahu bihi al-jami'a wa al-qari'a wa assami'a fi ad-dunya wa gadan amin." 


\section{Awrad Qadiriyah dan Rifa'iyah}

3000/Ts-3/MNSU/2012

Kertas Eropa

\author{
Arab \& Melayu
}

$21,5 \times 16 \mathrm{~cm}$

Prosa

$60 \mathrm{hlm}$

$14 \times 10,5 \mathrm{~cm}$
11 baris/hlm

\section{Pengarang}

Anonim

\section{Penulisan}

\section{Kolofon}

\section{Cap Kertas/Watermark}

Crescent

\section{Gambaran Isi}

Menjelaskan tentang wirid, zikir Tarekat Qadiriyah dan Rifa'iyah serta cara mengamalkannya.

\section{Keterangan}

Awal teks: "Bismillahi ar-rahmani ar-rahimi al-fatihata ila hadrati annabiyyi Muhammadin shalla Allahu 'alayhi wa sallama wa 'ala 'alihi wa ashabihi wa azwajihi wa dzurriyatihi wa ahli baytihi khushushan ila 'arwahi sadatina Abi Bakrin wa 'Umara wa 'Usmana wa 'Ali radhiyallahu Ta'ala'anhum al-Fatihah..."

Akhir teks: "... bermula jika pada bulan Jumadil Akhir [kaf-mimfa-ra] pada siang hari alamat bersua pada muara kerbau lembu berkurang pada tahun itu jika pada malam [kaf-mim-fa-ra] alamat segala orang muda-muda banyak." 


\section{Syifa al-Qulub}

$\begin{array}{cccc}\text { 3169/Ts-4a/MNSU/2012 } & \text { Arab \& Melayu } & \text { Prosa } & 63 \mathrm{hlm} \\ \text { Kertas Eropa } & 20 \times 16 \mathrm{~cm} & 16 \times 11,5 \mathrm{~cm} & 21 \mathrm{baris} / \mathrm{hlm}\end{array}$

\section{Pengarang}

Nuruddin bin 'Ali ibn Hasanji ibn Muhammad Hamid (ar-Raniry)

\section{Penulisan}

\section{Kolofon}

\section{Cap Kertas/Watermark}

Propatria

\section{Gambaran Isi}

Menjelaskan tentang wujudnya Allah Ta'ala, syahadat, musyahadah, dan mukasyafah.

\section{Keterangan}

Awal teks: "Bismillahi ar-rahmani ar-rahimi alhamdulillahi Rabbi al'alamina wa ash-shalatu wa as-salamu 'ala Muhammadin wa 'ala 'alihi waashabihi 'ajmaina, segala puji-pujian bagi Allah Tuhan seru alam sekalian..."

Akhir teks: "... wa shallallahu 'ala sayyidina Muhammadin wa 'alihi wa shahbihi wa sallama kullama dzakaraka adz-dzakiruna wasahiya 'an dzikrika al-gafiluna wa sallama tasliman katsiran birahmatika ya arhama ar-rahimina wa Allahu [a]'lam tammat. Kitab adanya faqih aran talaqi dada." 


\section{Jawahir al-'Ulum fi Kasyfi al-Ma'lum}

$\begin{array}{cccc}\text { 3169/Ts-4b/MNSU/2012 } & \text { Arab \& Melayu } & \text { Prosa } & 63 \mathrm{hlm} \\ \text { Kertas Eropa } & 20 \times 16 \mathrm{~cm} & 16 \times 11,5 \mathrm{~cm} & 21 \mathrm{baris} / \mathrm{hlm}\end{array}$

\section{Pengarang}

Nuruddin bin 'Ali ibn Hasanji ibn Muhammad Hamid (Ar-Raniry)

\section{Penulisan}

Aceh

\section{Kolofon}

\section{Cap Kertas/Watermark}

Propatria

\section{Gambaran Isi}

Menjelaskan tentang keesaan dzat Allah, ma'rifat, dan unsur-unsur ilmu tasawuf.

\section{Keterangan}

Awal teks: "Bismillahi ar-rahmani ar-rahimi alhamdulillah man tawahhada bi adz-dzati wa ash-shifati wa al-'asma'i fi al-qidami fatajalla bi dzatihi li dzatihi fi dzatihi wa kammala wa azzama segala puji-pujian bagi Tuhan yang esa la dengan dzat-Nya dan sifat-Nya dan asma-Nya pada azali maka adalah la tajalli la dengan zat-Nya bagi zat-Nya pada zat-Nya dan sempurnalah la dengan kebesaranNya...".

Akhir teks: “... jikaku kehendaki kesempurnaan perkataan ruh itu maka hendaklah ku mutala'ah-kan kitab Asrar al-Insan fi ma'rifati ar-ruh wa ar-Rahman yang telah kami ta'lif-kan insya Allah Ta'ala. Adalah ta'rif muayyanatu asy-syay $i$ bi asy-syay'i itu, yaitu pada istilah lugah seperti kata sahibu kamus 'qad manna Allahu sirrahu ma'a [al] li al-musahabati wa bima'na 'inda al-'Arab nahnu kuntu ma'a zaydin yakni makna ma'a itu bersama-sama itu". 
Diya al-Wara ila Suluki Thariqat al-Ma'budi al-'Ula
3141/Ts-5/MNSU/2012
Arab \& Melayu
Prosa
$60 \mathrm{hlm}$
Kertas Eropa
$23 \times 17 \mathrm{~cm}$
$17 \times 11,5 \mathrm{~cm}$
$17 \mathrm{baris} / \mathrm{h} / \mathrm{m}$

\section{Pengarang}

Anonim

\section{Penulisan}

\section{Kolofon}

\section{Cap Kertas/Watermark}

\section{Crescent}

\section{Gambaran Isi}

Menjelaskan tentang sifat munafik, tirakat, sifat-sifat hati, ridha dengan takdir, mengingat mati, dan akidah yang sahih.

\section{Keterangan}

Awal teks: "Bismillahi ar-rahmani ar-rahimi al-hamdulillahi al-ladzi awjaba 'ala'abdihi ta'atar-Rahmani. Segala puji bagi Allah yang mengwajib la atas hamba-Nya akan taat bagi Tuhan yang bernama Rahman..."

Akhir teks: "... kata Syeikh Ibn Atha'illah dalam Hikam,'ya 'ajaban yazharu al-wujudu fi al-'adami' hai yang sangat ajaib betapa zahir wujud dalam 'adam karena keduanya berlawanan yang tiada syah berhimpun keduanya. Wabillahi at-taufiku inilah akhir barang yang hamba qasad menyata akan dia dalam kitab ini haq." 
Naskah Tasawuf dalam Kitab 'Umdat al-Muhtajina ila Yaumi al-Dini Ya Rabb al-'Alamin

$\begin{array}{cccc}\text { 3166/Ts-6a/MNSU/2012 } & \text { Arab \& Melayu } & \text { Prosa } & 127 \mathrm{hlm} \\ \text { Kertas Eropa } & 20 \times 16 \mathrm{~cm} & 16 \times 11,5 \mathrm{~cm} & 21 \mathrm{baris} / \mathrm{hlm}\end{array}$

\section{Penulis}

Anonim

\section{Penulisan}

\section{Kolofon}

Syeikh Kampang ibn Kasi al-Multawa Tengku Ngombak Amin ya Rabb al-'alamina ditulis pada hari Senin waktu Dhuha.

\section{Cap Kertas/Watermark}

Crescent

\section{Gambaran Isi}

Menjelaskan tentang zikir, keutamaan la ilaha illa Allah, talqin dengan la ilaha illa Allah.

\section{Keterangan}

Awal teks: "Bismillahi ar-rahmani ar-rahimi al-hamdulillahi alladzi'alima nafsahu wasifatahu wa al-'asy-ya'u mujmalahu wakana 'ilmuhu biha'ala sabili al-ïjmali wahdatihi fahiya al-haqiqatu alMuhammadiyyatu. Segala puji bagi Allah yang telah mengetahui diri-Nya dan segala sifat-Nya dan segala perkara pada jalan mujmal dan adalah pengetahuan-Nya akan dia atas jalan ijmal itu martabat wihdat-Nya itulah hakikat Muhammadiyyah..."

Akhir teks: "... artinya hendaklah kau fana-kan dirimu hingga daripada fana-mu pun maka bahwasanya fana daripada fana itulah keadaan bagamaka tatkala itu kulihat akan dia tetap adalah yang 
demikian itu sedikit tetapnya pada kita, maka apabila tetaplah ia pada kita niscaya naiklah kita kepada alam yang tinggi wa billahi at-tawfiqu wa sallallahu 'ala sayyidina Muhammadin wa 'ala 'alihi wasahbihi wasallama. Tammat al-kitabu tamma."

Di dalam naskah ini juga ada ilustrasi mengenai zikir "Allah" dan "La ilaha illaAllah Muhammadun rasulullah Allah Allah Huwa Huwa". 


\section{'Umdat al-Muhtajina ila Suluki Maslaki al-Mufradina}

3137/Ts-7/MNSU/2012

Arab \& Melayu

Prosa

$64 \mathrm{hlm}$

Kertas Eropa

$12,5 \times 16,5 \mathrm{~cm} \quad 15 \times 9 \mathrm{~cm}$

19 baris/hlm

\section{Penulis}

Anonim

\section{Penulisan}

\section{Kolofon}

\section{Cap Kertas/Watermark}

\section{Crescent}

\section{Gambaran Isi}

Menjelaskan tentang hakikat la ilaha illa Allah, dan pedoman berzikir. Di dalam naskah ini juga terdapat teks tentang fiqih dan tauhid.

\section{Keterangan}

Awal teks: "Bismillahi ar-rahmani ar-rahimi al-hamdulillahi Rabbi al'alamina wa ash-shalatu wa as-salamu 'ala sayyidina Muhammadin wa 'ala'alihi wa sahbihi ajma'ina artinya dengan nama Allah yang amat murah lagi amat mengasihani hamba-Nya mukmin dalam akhirat jua aku memulai membaca kitab ini segala puji bagi Allah Tuhan sekalian alam..."

Akhir teks: "... kelima, meng-i'tiqad-kan bahwa ia minta tolong daripada Syeikhnya itu serasa ia minta tolong daripada Nabi sallallahu 'alayhi wasallama karena ia gantinya dan adapun segala adab yang pada ketika zikir itu pertama duduk atas tempat yang suci..." 


\title{
Bustan al-Salikin
}

3156/Ts-8/MNSU/2012

\author{
Arab \& Melayu
}

Prosa

$188 \mathrm{hlm}$

Kertas Eropa

$15 \times 10 \mathrm{~cm}$

17 baris/hlm

\section{Penulis}

Anonim

\section{Penulisan}

\section{Kolofon}

\section{Cap Kertas/Watermark}

Crescent

\section{Gambaran Isi}

Menjelaskan tentang macam-macam nafsu, sifat-sifat hati, syarat mujahadah dan riyadah serta keutamaan menetapi rasa lapar, menyedikitkan tidur di malam hari dan berbagai aspek tasawuf lainnya. Di dalam naskah ini juga ada teks berisi ajaran ilmu fiqih ibadah (takbiratu al-ihram), fiqh mu'amalah tentang makanan yang halal dan haram dan beberapa hal lainnya.

\section{Keterangan}

Awal teks: "Bismillahi ar-rahmani ar-rahimi al-hamdulillahi Rabbi al'alamina wa al-'aqibatu li al-muttaqinasegala puja puji bagi Allah Tuhan seru alam sekalian bermula negeri akhirat itu sabit-lah ia bagi orang yang takut akan Allah,wa ash-shalatu wa as-salamu 'ala sayyidina Muhammadin wa 'alihi wa sahbihi 'ajma'ina dan rahmat Allah dan salam Allah itu atas penghulu kami Muhammad dan atas segala keluarganya dan segala sahabatnya sekalian mereka itu..." Akhir teks: "... maka adalah istidraj itu lupa ia akan akan Allah Ta'ala dan $k$ [...] ia dengan yang lain daripadanya dan berpegang dengan yang lain daripadanya." 
Diya al-Wara ila Suluki Thariqat al-Ma'budi al-'Ula

$\begin{array}{cccc}\text { 3159/Ts-9/MNSU/2012 } & \text { Arab \& Melayu } & \text { Prosa } & 69 \mathrm{hlm} \\ \text { Kertas Eropa } & 22,5 \times 17 \mathrm{~cm} & 17 \times 10 \mathrm{~cm} & 19 \mathrm{baris} / \mathrm{h} / \mathrm{m}\end{array}$

\section{Pengarang}

Anonim

\section{Penulisan}

\section{Kolofon}

\section{Cap Kertas/Watermark}

Propatria

\section{Gambaran Isi}

Menjelaskan tentang nafsu, bahaya bohong, marah, hasud,'ujub, takabur dan riya. Menjaga sifat syukur danistiqamah. Selanjutnya penjelasan yang berkaitan dengan elemen-elemen tasawuf sepertiraja', khawf, tawakkal, dan lain sebagainya. Di dalam naskah ini juga dijelaskan tentang martabat dan sifat-sifat Allah.

\section{Keterangan}

Awal teks: "Bismillahi ar-rahmani ar-rahimi al-hamdulillahi al-ladzi awjaba 'ala'abdihi ta'atar-Rahmani. Segala puji bagi Allah yang mengwajib ia atas hambanya akan taat bagi Tuhan yang bernama Rahman..."

Akhir teks: "... dan syarat sembahyang tarekat itu mu menyuci nafsunya dan air wudhu dan syarat sembahyang hakikat itu menyuci rahasianya dengan air tujuh fa 'idza faragta fansab wa ila Rabbika fargab. Maka sembahyang syariat itu berwaktu dan sembahyang tarekat itu ketika datang hawa nafsu dan sembahyang dan hakikat itu tiada bermasa karena ia fisalatihim da'imuna. Tammat imla [...] raya". 


\section{Mawa'iz al-Badi'}

$\begin{array}{cccc}\text { 3135/Ts-10/MNSU/2012 } & \text { Melayu } & \text { Prosa } & 112 \mathrm{hlm} \\ \text { Kertas Eropa } & 22 \times 16,5 \mathrm{~cm} & 15 \times 9,5 \mathrm{~cm} & 17 \text { baris } / \mathrm{hlm}\end{array}$

\section{Pengarang}

Abdul Rauf bin 'Ali (informasi pada proses invetarisasi awal)

\section{Penulisan}

\section{Kolofon}

\section{Cap Kertas/Watermark}

\section{Crescent}

\section{Gambaran Isi}

Berisikan petuah-petuah berkaitan dengan akhlak menjaga hati dan unsur-unsur tasawuf.

\section{Keterangan}

Awal teks: "Bismillahi ar-rahmani ar-rahimi kumulai kitab ini dengan nama Allah yang amat murah pada memberi rizki akan segala hamba-Nya mukmin di dalam negeri dunia ini lagi yang amat mengasihani akan segala hamba-Nya mukmin di dalam akhirat itu..."

Akhir teks: "... maka takut olehmu akan yang demikian itu maka bahwasanya itu bala daripada Allah Ta'ala itu. Amin. Tammat kitab yang bernama Mawa'iz al-Badi'." 


\section{Kaifiyat Zikir}

3136/Ts-11/MNSU/2012

Arab \& Melayu

Prosa

$40 \mathrm{hlm}$

Kertas Eropa

$23,5 \times 17 \mathrm{~cm}$

$21,5 \times 14 \mathrm{~cm}$

30 baris/hlm

\section{Pengarang}

Muhammad Syafe'i ibn Abdul Karim

\section{Penulisan}

\section{Kolofon}

\section{Cap Kertas/Watermark}

Crescent

\section{Gambaran Isi}

Berisi tatacara berzikir dan berdoa,penjelasan tentang keutamaan taubat, dan berbagai doa.

\section{Keterangan}

Awal teks: "Bismillahi ar-rahmani ar-rahimi al-hamdulillahi wahdahu wa ash-shalatu wa as-salamu 'ala man la nabiyya ba'dahu 'amma ba'du fa qala al-faqiru al-haqiru al-mustagriqu fi bahri al-gaflati Muhammad Syafi'i ibn Abd al-Karimi al-mannu lillahi as-sahihi..."

Akhir teks: "... bahwa kita ketahui malakal-maut dengan ia memeri salam serta menyampaikan salam Haq Ta'ala seperti yang telah tersebut lafaz salamnya dalam risalah ini wa sallallahu 'ala sayyidina Muhammadin wa 'ala 'alihi wasahbihi wasallama amin. Qabulu mu 'minin talibu du'a." 


\section{Bidayat al-Mubtadi bi Fadlillahi al-Muhdi}

$\begin{array}{cccc}\text { 2583/Ts-12/MNSU/2012 } & \text { Arab \& Melayu } & \text { Prosa } & 150 \mathrm{hlm} \\ \text { Kertas Eropa } & 27,5 \times 19 \mathrm{~cm} & 22 \times 13,5 \mathrm{~cm} & 9-33 \mathrm{baris} / \mathrm{hlm}\end{array}$

\section{Pengarang}

Anonim

\section{Penulisan}

\section{Kolofon}

\section{Cap Kertas/Watermark}

Gambar Rusa bertanduk terbalik

\section{Gambaran Isi}

Berisi tentang penjelasan al-a'yan as-sabitah, alam ruh, musyahadah dan tajalli, selain itu mengandung pembahasan tauhid, fiqih, dan lain-lain.

\section{Keterangan}

Awal teks: "Bismillahi ar-rahmani ar-rahimi dengan nama Allah jua aku memulai membaca risalah ini la jua tuhan yang amat murah pada menganugerahi rezki atas segala hamba-Nya mukmin dan kafir dalam negeri dunia lagi yang amat mengasihani dan menyayangi hamba-Nya yang mukmin dalam negeri akhirat. Alhamdulillahi alladzi arsyadana ila dinihi wa akramna min sa'ir al-'umami binabiyyihi segala puji-pujian bagi Allah Tuhan yang menunjuki kami jalan kepada agama-Nya dan dipermulia-Nya akan kami daripada segala umat sebab nabi-Nya Muhammad SAW ..."

Akhir teks:"... yaitu meng-i'tiqad-kan bahwasannya sebenarnya Allah Ta'ala menyuruhkan pesuruh kepada segala makhluk-Nya daripada manusia laki-laki merdeka lagi budiman benar lagi kepercayaan 
dan disampaikan mereka itu kepada segala makhluk barang yang dititahkan Allah Ta'ala mereka itu menyampaikan dia kepadanya supaya zahir jalan bahaya dan celaka dan tiadalah dapat [...]". 


\section{Syifa al-Qulub}

$\begin{array}{cccc}\text { 3161/Ts-13a/MNSU/2012 } & \text { Arab \& Melayu } & \text { Prosa } & 95 \mathrm{hlm} \\ \text { Kertas Eropa } & 15,5 \times 10,5 \mathrm{~cm} & 11,5 \times 6,5 \mathrm{~cm} & 15 \mathrm{baris} / \mathrm{h} / \mathrm{m}\end{array}$

\section{Pengarang}

Nuruddin ar-Raniri

\section{Penulisan}

\section{Kolofon}

\section{Cap Kertas/Watermark}

Propatria

\section{Gambaran Isi}

Berisipenjelasan tentang keutamaan la ilaha illa Allah, zikir, martabat-martabat sufi, dan lain-lain.

\section{Keterangan}

Awal teks: "Bismillahi ar-rahmani ar-rahimi al-hamdulillahi wa ashshalatu wa as-salamu 'alaMuhammadin wa 'ala'alihi wasahbihi 'ajma'ina segala puji-pujian bagi Allah Tuhan seru alam sekalian dan rahmat Allah dan salam-Nya atas Nabi Muhammad dan atas segala keluarganya dan sahabatnya segala sekalian 'amma ba'du. Adapun kemudian dari itu maka berkata hamba yang muhtaj kepada yang Amat Kaya lagi Maha Besar yaitulah Syeikh Nuruddin Ali bin Hasanji bin Muhammad Hamid..."

Akhir teks:"... man 'arafa nafsahu bi al-fana'i fagad 'arafa Rabbahu bi al-baqa'i yakni barangsiapa mengenal diri, maka bahwasanya mengenal Tuhannya yang Baqa adapun 'ana itu dua bagi sesuatu, 'ana majazi maka 'ana majazi itu makhluk yaitu muhdis adapun 'ana Haq Ta'ala qadim lagi 'azali maka tatkala takbiratul ihram maka hilanglah 'ana makhluk tinggallah sendirinya..." 
Tuhfat al-Syariffi Tahqiqi Asrar al-Latif

$\begin{array}{cccc}\text { 3161/Ts-13b/MNSU/2012 } & \text { Arab \& Melayu } & \text { Prosa } & 95 \mathrm{hlm} \\ \text { Kertas Eropa } & 15,5 \times 10,5 \mathrm{~cm} & 11,5 \times 6,5 \mathrm{~cm} & 15 \mathrm{baris} / \mathrm{hlm}\end{array}$

\section{Pengarang}

Anonim

\section{Penulisan}

\section{Kolofon}

\section{Cap Kertas/Watermark}

Tidak ada

\section{Gambaran Isi}

Berisi tentang keutamaan zikir, ibadah syariat, dan keutamaan kalimat la ilaha illa Allah, martabat-martabat sufi, dan lain-lain.

\section{Keterangan}

Awal teks: "... subhana bi tuhfati syariffi tahqiqi 'asrar al-latif wa fiha adzkuruhu ma'na at-tasmiyati wa as-salami fi al-lugati wa al-'istilahi. Akhir teks: "... yakni apabila telah zahir-lah keesaan dan ketuhanan Haq Ta'ala tidak berkehendak pada membicarakan dia sesuatu kata 'arif-qaddasallahu sirrahu-man talaba al-bayana ba'da al'ayani fahuwa fi al-khusrani yakni barang siapa kenyataan sesuatu kemudian daripada sudah nyata maka yaitulah sesuatu dalam merugi. Wa sallallahu 'alayhi khayri khalqihi Muhammadin wa 'alihi wasahbihi 'ajma'ina,amin, tammat". 


\section{Hidayat al-Muttaqin}

$\begin{array}{cccc}\text { 2940/Ts-14/MNSU/2012 } & \text { Arab \& Melayu } & \text { Prosa } & 46 \mathrm{hlm} \\ \text { Kertas Eropa } & 22,5 \times 16,5 \mathrm{~cm} & 16 \times 10,5 \mathrm{~cm} & 19 \mathrm{baris} / \mathrm{hlm}\end{array}$

\section{Pengarang}

Abdul Rahim Jawi al-Asyi

\section{Penulisan}

Siang hari Senin bulan Zul Qa'dah dalam 10 hari

\section{Kolofon}

Tammat kitab Hidayatal-Muttaqin pada hari Ahad pada waktu Ashar

\section{Cap Kertas/Watermark}

Crescent

\section{Gambaran Isi}

Berisi tentang ajaran sikap berserah diri (tawakkal) dan qana'ah. Selain itu,isi kitab ini memperingatkan akan bahaya dunia dan hawa nafsu, serta penjelasan lainnya.

\section{Keterangan}

Awal teks: "Bismillahi ar-rahmani ar-rahimi al-hamdulilahi 'aqama as-samawati bi gayrial-'imadi [wa hasyara] wa khabara bi al-jannati liman yatawakkalu 'ala Allahi bi as-sidqi wa al-'i'tiqadi artinya segala puji-pujian bagi Allah yang berdiri ia akan tujuh lapis langit dengan ketiadaan [ta-alif-mim-hah] dan mengkhabari la dengan syurga bagi barangsiapa yang tawakal karena Allah dengan benar i'tiqad..." Akhir teks:"... wa kana al-faragu min taswidi hadzihi al-bayadi nahara isnayni fi syahri Dzi al-Qa'dati fi asyrati yaumin wa huwa ta'lifu Abdi ar-Rahimi Jawi al- 'Asyi barang jala muhdah min Imam bin Khatib 
allahumma sabbit qadami'alaas-sirati 'ala hidayati ruhi sayyidina Muhammadin saw tammat kitabu Hidayatal-Muttaqin pada hari ahad pada waktu ashar wa sallallahu 'ala sayyidina Muhammadin wa 'alihi wasahbihi 'ajma'inaamin amin." 
Kitab al-Majmu'

3163/Ts-15/MNSU/2012

Kertas Eropa

\author{
Arab \& Melayu \\ Prosa
}

$21 \times 15,5 \mathrm{~cm}$
$120 \mathrm{hlm}$

15 baris/hlm

\section{Pengarang}

Anonim

\section{Penulisan}

\section{Kolofon}

Tammat al-Kitab al-Majmu' pada hari Jum'at pada bulan Safar pada waktu Dhuha pada Bandarsah di kampung wakutubihi \{wakatibuhu\} wa sahibuhu Lebeh Pualam yang menyurat kitab ini yang empunya dirinya.

\section{Cap Kertas/Watermark}

Crown Propatria

\section{Gambaran Isi}

Kitab ini membahas tentang ilmu tauhid, namun mengandung sisisisi tasawuf seperti penjelasan sifat ikhlas dan masalah-masalah ma'rifat. Kitab ini sudah tidak lengkap.

\section{Keterangan}

Awal teks: "... siddiq artinya benar dan amanah artinya kepercayaan dan tablig artinya menyampaikan dan yang jaiz itu yaitu perangai tubuh manusia seperti makan dan minum dan tidur dan sakit dan barang sebagai dan yang mustahil itu yaitu kadzib artinya dusta dan khiyanat, artinya melebihi atau mengurangi dan kitman artinya membunikan \{menyembunyikan\}..."

Akhir teks:"... Tammat al-Kitab al-Majmu'pada hari Jum'at pada bulan Safar pada waktu dhuha pada Bandarsah di kampung wakutubihi \{wakatibuhu\} wa sahibuhu Lebeh Pualam yang menyurat kitab ini yang empunya dirinya." 


\section{Kitab Agama Islam dan Iman dan Tauhid dan Ma'rifat}

$\begin{array}{cccc}\text { 3163/Ts-15b/MNSU/2012 } & \text { Arab \& Melayu } & \text { Prosa } & 120 \mathrm{hlm} \\ \text { Kertas Eropa } & 21 \times 15,5 \mathrm{~cm} & 12 \times 9 \mathrm{~cm} & 15 \mathrm{baris} / \mathrm{hlm}\end{array}$

\section{Pengarang}

Anonim

\section{Penulisan}

\section{Kolofon}

\section{Cap Kertas/Watermark}

Crown Propatria

\section{Gambaran Isi}

Kitab ini membahas tentang keutamaan la ilaha illa Allah dan martabat tujuh.

\section{Keterangan}

Awal teks:"Adapun ketahui olehmu hai segala mukmin bahwasanya kalimat la ilaha illa Allah itu beberapa namanya karena ia terlebih mulia daripada segala kalimat yang lain daripadanya karena asal sekalian kalimat maka adalah dalil yang menyatakan kelebihannya kalimat la ilaha illa Allah itu yaitu firman Allah Ta'ala wa'lam 'annahu la ilaha illa Allah artinya ketahui olehmu asal iman itu yaitu la ilaha illa Allah sebab itulah banyak namanya karena kelebihannya daripada yang lain daripadanya..."

Akhir teks: Tammat al-kitab ini agama Islam dan iman dan tauhid dan ma'rifat tammat wa Allahu 'a'lamu bi as -sawabi tammat [baghin-sin, ba-ghin-sin]." 
Bab 4: Koleksi \& Katalogisasi: Naskah Tasawuf di Propinsi Sumatera Utara 


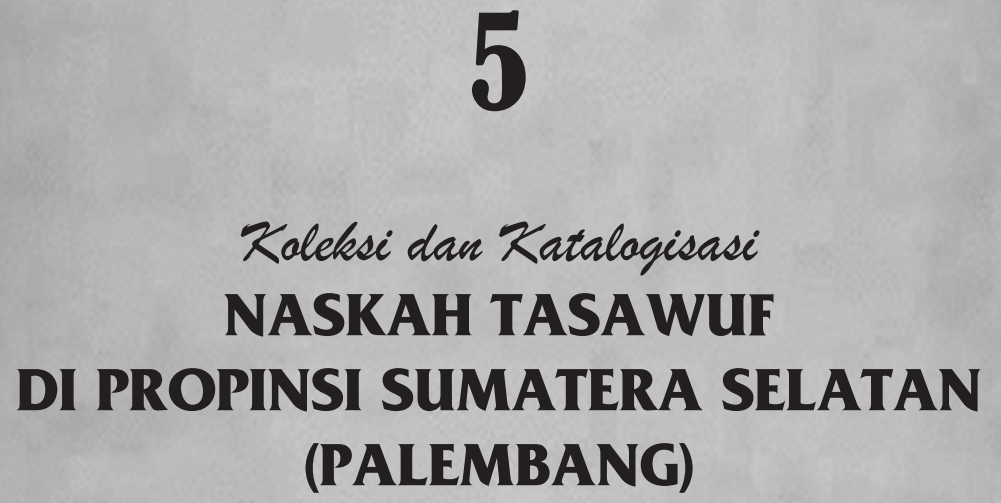

Oleh:

Muhammad Tarobin

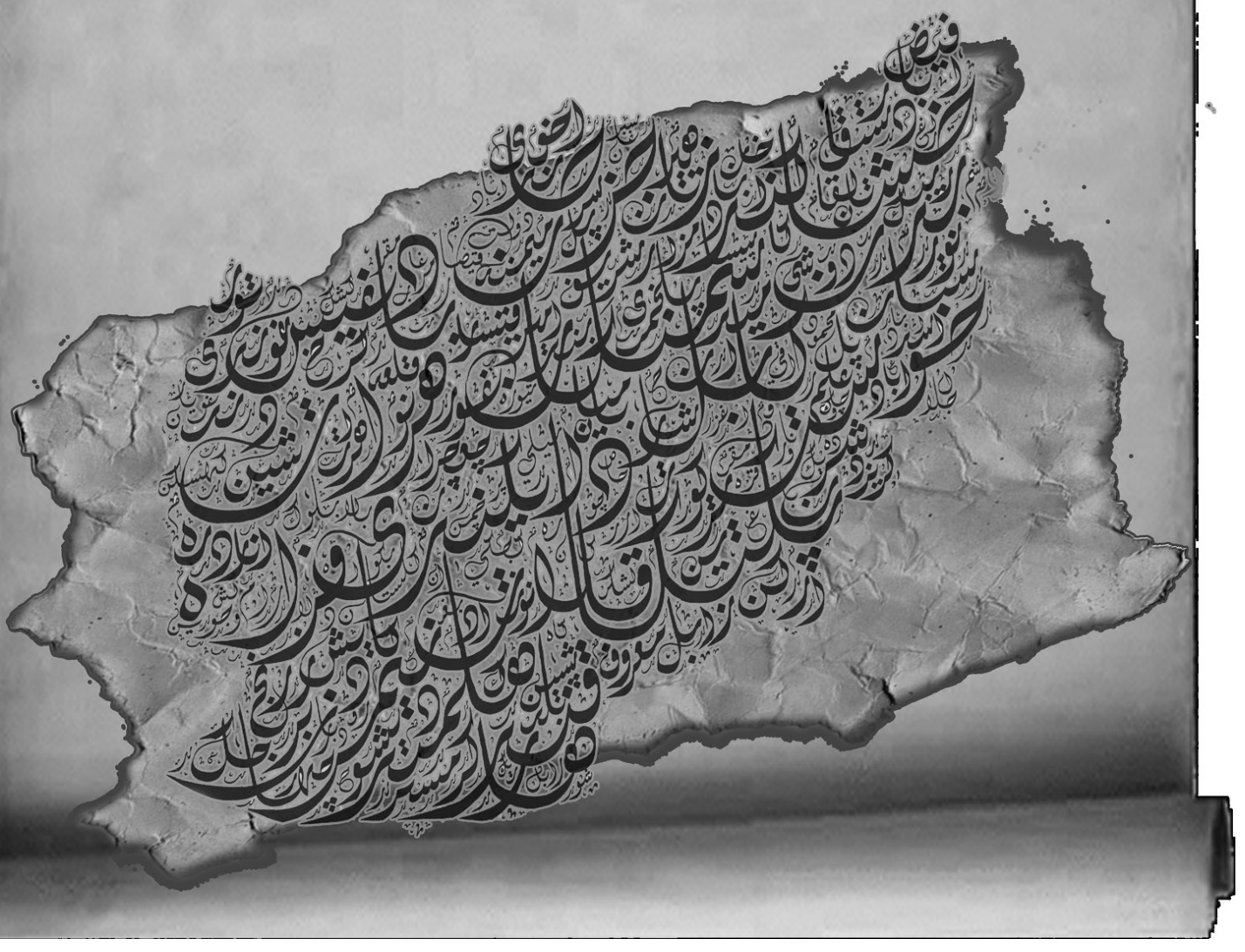




\section{Al-Hikam}

Ts/22/AS/BLAJ-SS/001

Kertas Eropa

\author{
Arab-Melayu \\ $21 \times 17$
}

\begin{abstract}
Prosa
\end{abstract}
$14 \times 9$
110 hal

19/hal

\section{Pengarang}

Taj al-Din Abu al-Fadhl Ahmad anak Muhammad anak'Abd al-Karim anak'Atha'illah, Ibn 'Atha'illah al-Sakandari (w. 709 H/1309 M).

\section{Kolofon}

"Alamat kitab wakaf Raden Muhammad Zain ibn Raden Ismail ibn al-marhum Pangeran Natadikrama ibn al-marhum Paduka Sultan Muhammad Bahauddin Palembang, Kampung Enam Belas Ilir adanya."

\section{Cap Kertas}

Lion in medallion: Concordia

\section{Gambaran Isi}

Merupakan teks tasawuf akhlaqi. Berisi kumpulan mutiara hikmah bagi kesempurnaan seorang pelaku tasawuf. Misalnya, hikmah pertama: "Min 'alamati al-i'timadi 'ala al-'amali nuqshanu al-raja'i 'inda wujudi al-zalal". Hikmah ini menjelaskan, bahwa tanda seseorang itu bersandar pada kekuatan amal usahanya adalah berkurang harapannya ketika berlaku padanya kesalahan. Hikmah lainnya misalnya tentang ahl al-asbab dan ahl al-tajrid, kekuatan benteng takdir, dan seterusnya.

\section{Keterangan}

Kertas sebagian masih baik dan sebagian lainnya sudah mulai rapuh. Warna sudah kehitaman karena usia dan jamur. Tulisan berwarna hitam dan merah (rubrikasi). Naskah terdiri dari 129 halaman; 110 halaman yang ditulis dan 18 halaman kosong (enam halaman pada bagian awal dan dua belas halaman pada bagian akhir); ditulis 
dengan spasi rapat tanpa garis panduan. Naskah masih lengkap dan bersampul bahan kulit berwarna coklat bermotif. Nomor halaman ditulis dengan angka latin di tengah sebelah bawah, agaknya dibubuhkan sebelum dikoleksi. Teks ditulis dengan bahasa Arab di awal dan diikuti dengan teks berbahasa Melayu.

Awal teks berbunyi, "Bismillahi al-rahmani al-Rahimi. Kitab Syeikh Imam Taj al-Din Abu al-Fadhl Ahmad anak Muhammad 'Abd al-Karim anak 'Atha'illah, min 'alamati al-i'timadi 'ala al-'amali nuqsanu alraja 'inda wujud al-zalali." Artinya, setengah daripada alamat yang berjaya atas 'amal itu kurang harapnya tatkala diperoleh zalal yakni tatkala keluar daripada yang dimaksudkannya..."

Bagian akhir teks berbunyi: "...dengan sempurna baiknya maka tahqiq-lah akan kebesaran-Nya segala isi betapa Engkau terbuat dan Engkau jua yang nyata dan menyatakan segala tempat, wa Allahu al-muwafiq wa bihi nasta'in, bermula Allah jua yang menolong, dan dengan Dia jua kita minta tolong. Wa Allahu a'lam." 


\section{Bidayah al-Hidayah}
Ts/25/AS/BLAJ-SS/002
Kertas Eropa

\author{
Arab-Melayu
}

$20 \times 16 \mathrm{~cm}$

Prosa

$14.5 \times 12 \mathrm{~cm}$
146 hal

16 baris/hlm

\section{Pengarang}

Muhammad Zayn ibn al-Faqih Jalaluddin al-Shafi'i al-'Ashi.

\section{Penyusunan}

Dalam Iskandar (1995: 433) disebutkan dikarang di Makkah, 24 Sya'ban 1170 H/14 Mei 1757 M; sedangkan dalam ML 341B PNRI hanya tertulis "dua puluh empat hari bulan Sya'ban." Sedangkan kolofon naskah ini sendiri sulit dipahami.

\section{Kolofon}

"Wa katabaha wa huwa 92 bin al-Hajj 91 bin al-Hajj 15 bin al-Haj 111 bin al-Hajj 64 bin al-Hajj 156 fana'an."

\section{Cap Kertas}

Lion in Medallion: Pro Patria Eendragt Maakt Magt (3.2).

\section{Gambaran Isi}

Naskah berisi penjelasan ilmu ushuluddin. Bagian awal teks berisi peringatan bahwa orang-orang yang ingin mempelajari ilmu ini hendaklah dengan orang yang telah menguasai dan mahir di bidangnya. Pembukaan berisi pentingnya basmalah dalam memulai sesuatu, empat makna pujian (hamdalah) bagi Allah, kemudian kitab menjelaskan tentang pengetahuan dan hukum, kewajiban mengenal Allah, mengenal para rasul, dan seterusnya.

\section{Keterangan}

Naskah ini dijilid dengan bahan kulit yang berwarna hijau tua, terdiri dari 146 halaman; 130 halaman yang ditulis dan 16 halaman kosong. Ditulis dengan spasi rapat. Naskah masih lengkap. Nomor 
halaman tidak ada, yang ada kata alihan. Teks ditulis dalam bingkai yang dibuat dengan tinta hitam. Teks ditulis dengan bahasa Arab, kemudian diikuti dengan bahasa Melayu. Kondisi kertas pada halaman tertentu telah menunjukkan kerapuhan, terlihat dari warna kertas yang agak kehitam-hitaman. Tulisan berwarna hitam dan merah (rubrikasi).

Teks merupakan syarah bahasa Jawi dari kitab Umm al-Barahin karya Abi 'Abdillah Muhammad ibn Yusuf al-Sanusi al-Hasani (w. 895 H/1490 M). Teks awal berbunyi, "Bismillahi al-rahmani al-rahim, wa bihi nasta'in, al-hamdu lillahi al-ladhi dalla bi wujudihi jami'a alka'inat. Dengan nama Allah yang maha murah lagi mengasihani akan hambanya aku memulai kitab, dengan Dia kita minta tolong segala puji bagi Allah."

Teks akhir berbunyi, "...wa billahi al-taufik wa hasbuna Allah wa ni'ma al-wakil wa la hawla wa la quwwata illa billahi al-'aliyyi al-'azimi. Wa salla Allahu 'ala sayyidina Muhammad sayyidi al-awwali wa alakhiri wa 'ala alihi al-thahirin wa al-sahabah ajma'in wa al-hamdu lillahi Rabbi al-'alamin. Allahumma salli 'ala Muhammad wa 'ala ali Muhammad."

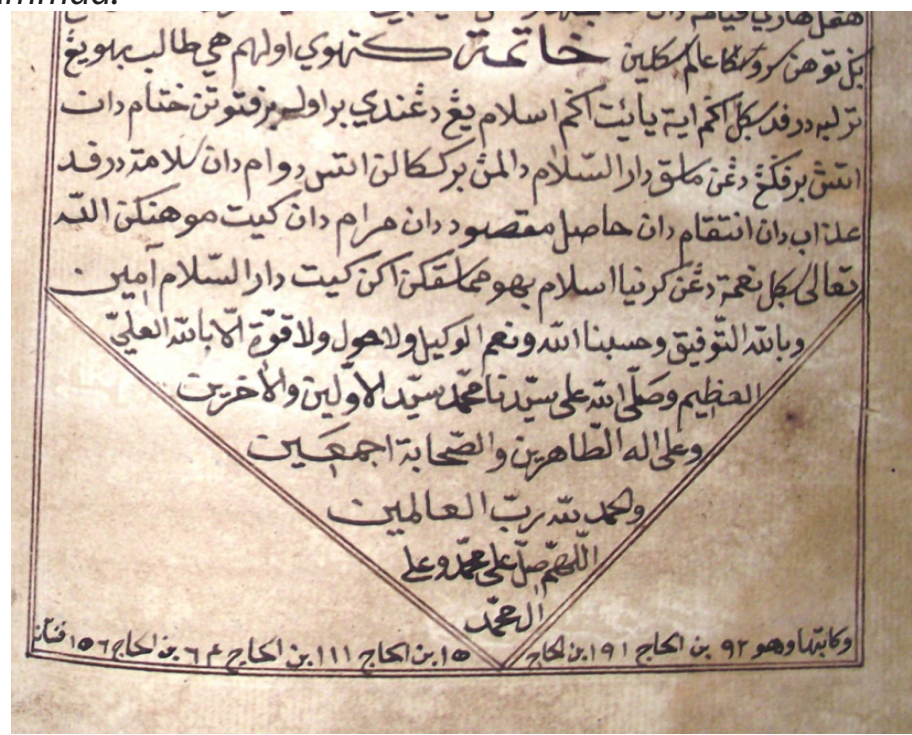

Kolofon: Bidayah al-Hidayah/Ts/25/AS/BLAJ-SS/002. 


\section{Faiz al-Ihsani}

$\begin{array}{cccc}\text { Ts/49/AS/BLAJ-SS/003 } & \text { Melayu } & \text { Prosa } & 52 \text { hal } \\ \text { Buku Tulis Bergaris } & 20.5 \times 16 & 15 \times 11.5 & 13 / \mathrm{hal}\end{array}$

\section{Penulisan}

Palembang, 5-2-1937

\section{Pemilik}

Nyayu Halimah, tertulis "Yang mempunyai ini kh-m-I (th?) Nyayu Halimah."

\section{Kolofon}

"Memulai saya menulis ini pada tanggal 5-2-tahun 1937. Bismillahi al-rahman al-rahim. Qala ya 'Abd al-Shamad al-madad."

\section{Gambaran Isi}

Naskah menguraikan tentang riwayat hidup (manaqib) Syeikh 'Abd al-Shamad al-Falimbani (1736-1818), seorang ulama sufi Palembang. Setelah muqaddimah, lalu diceritakan tentang biografi, nasihat, wasiat dan keramat Syeikh 'Abd al-Shamad.

\section{Keterangan}

Naskah ditulis dalam bingkai dengan spasi rapat. Naskah masih lengkap dan naskah ini pun telah dialihaksarakan oleh pemiliknya, Kemas H. Andi Syarifuddin, pada tahun 1977. Nomor halaman ditulis dengan angka Arab di pinggir sebelah kiri. Teks dengan bahasa Melayu ditulis mendatar. Bahan yang digunakan buku tulis bergaris. Kondisi kertas sudah kecoklat-coklatan. Tulisan bewarna biru dan merah (rubrikasi). Secara keseluruhan teks masih dapat dibaca. Pada bagian sampul belakang tertulis "FIRMA BAN SI-G HOEAT PALEMBANG."

Awal teks berbunyi,"Bismillahi al-rahman al-rahim. Alhamdu li Allah al-ladhi fataha al-quluba auliya' bi mafatihi anwari al-tauhid wa al- 
Iman. Artinya segala puji itu bagi Allah Ta'ala yang membukakan ia akan hati segala auliyanya...."

Teks akhir berbunyi, "...Bismillahi al-rahman al-rahim, Allahumma shalli wa sallim ala sayyidina Muhammad fi al-awwalin wa shalli wa sallim 'ala sayyidina Muhammad fi al-akhirina wa shalli wa sallim ala sayyidina Muhammad fi al-mala'i al-a'la ila yaumi al-din." 


\section{Risalah Mukhtasharah al-Ma'rifah}

$\begin{array}{cccc}\text { Ts/38/AS/BLAJ-SS/004 } & \text { Arab-Melayu } & \text { Prosa } & 174 \text { hal } \\ \text { Kertas Eropa } & 22 \times 16.5 & 15.5 \times 10 & 19 / \mathrm{hal}\end{array}$

\section{Cap kertas}

Tiga bulan sabit berjajar

\section{Gambaran Isi}

Naskah menguraikan rukun Islam yang lima, wajib diucapkan bagi orang Muslim yang aqil balig. Selanjutnya pembahasan mengenai bersujud kepada Allah dan maknanya disertai dengan surat-surat dalam Al-Qur'an mengenai sujud.

\section{Keterangan}

Naskah masih lengkap, namun penjilidannya agaknya telah mengalami perubahan. Naskah dijilid dengan sampul karton. Penomoran halaman tidak ada begitu juga dengan kata alihan. Teks ditulis dengan bahasa Arab dan terjemah Melayu ditulis mendatar. Teks bahasa Arab ditulis lebih dulu satu kalimat, kemudian dilanjutkan dengan bahasa Melayu sebagai terjemahannya dan tidak ada garis panduan.

Kondisi kertas sudah rapuh, terlihat dari bagian sisinya hancur. Sebagian kertas warnanya sudah kehitam-hitaman karena usia dan jamur yang mengembang. Tulisan ditulis dengan tinta hitam dan beberapa kata ditulis dengan tinta merah ( rubrikasi).

Awal teks yang terbaca, "Bismillahi al-Rahmani al-rahimi. Alhamdu lillahi rabbi al-'alamin wa al-'aqibatu li al-muttaqin. al-shalatu wa al-salamu 'ala sayyidina Muhammad sayyidi al-anbiya'i wa almursalin wa alihi wa sahbihi al-thayyibin al-thahirin; Artinya, segala puji itu teruntuk bagi Allah Tuhan serta alam sekalian, kebajikan akhirat itu bagi segala orang yang takwa akan Allah dan rahmat dan selamanya atas penghulu kita Nabi Muhammad penghulu segala nabi dan segala pesuruh dan segala keluarganya dan segala 
sahabatnya yang baik mereka itu lagi suci mereka itu daripada kejahatan dosa..."

Bagian akhir teks yang terbaca,"... la ilaha illa hu 'alaihi tawakkaltu wa huwa rabb al-'arshi al-'azim, tiga kali, wa la hawla wa la quwwata illa billahi al-'aliyyi al-azim wa salla allahu ala sayyidina Muhammad wa'ala alihi wa sahbihi wa sallama". 


\section{Al-Sayr wa al-Suluk ila Malik al-Muluk}

$\begin{array}{cccc}\text { Ts/27B/AS/BLAJ-SS/005 } & \text { Arab-Melayu } & \text { Prosa } & 22 \text { hal } \\ \text { Kertas Eropa } & 21 \times 16.5 & 15 \times 9 & 14 / \text { hal }\end{array}$

\section{Penerjemah}

Kemas Fakhruddin

\section{Penulisan}

Palembang

\section{Kolofon}

"Intaha, nukil daripada kitab al-Sayr wa al-Suluk ila Malik al-Muluk li al-shaykh al-kamil al-'arif billahi sayyidi al-syeikh Qasim al-Hallabi qaddasallahu sirrahu. Dan adalah yang menterjemahkan dia kemas Fakhruddin di dalam Negeri Palembang Darussalam thumma amin, tammat."

\section{Cap Kertas}

Singa bermahkota dalam lingkaran, LWC dengan delapan garis tipis.

\section{Gambaran Isi}

Ajaran tasawuf akhlaqi, merupakan nukilan dari kitab al-Sayr wa al-Suluk berbahasa Arab pada bab empat sampai sepuluh yang menguraikan tentang tingkatan-tingkatan nafsu, juga tingkatantingkatan maqam berdasarkan nafsu yang mendominasi jiwa seseorang yakni dari nafsu ammarah, lawwamah, mulhamah, muthmainnah, radhiyah, mardhiyyah, dan nafsu kamilah.

\section{Keterangan}

Teks al-Sayr wa al-Suluk merupakan teks kedua dalam naskah yang terdiri atas empat teks yakni: anonim (1-41), al-Sayr wa al-suluk (44-65), biografi Raden Abdul Aziz ibn al-Faqir (66-83), dan Kashf 
al-Kiram (90-108). Teks al-Sayr wa al-suluk merupakan teks tasawuf karya Syeikh Qasim b. Shalah al-Din al-Khani al-Hallabi (w. 1109 H/1698 M).

Awal teks al-Sayr wa al-suluk berbunyi,"Bismillahi al-Rahmani alRahimi. Al-hamdu lillahi rabbi al-'alamin, al-shalathu wa al-salamu 'ala sayyidina Muhammad khatim al-nabi wa 'ala alihi wa sahbihi..." Bagian akhir teks berbunyi,"kitab as-Sair wa as-suluk ila Maluk al-Muluk li as-Syeikh Qasim al-Halbi qaddasa Allah sirruhu...yang menerjemahkan dia Kemas Fakhruddin dalam negeri Palembang Darussalam summa amin. Tammat." 


\section{Kasyf al-Kiram fi Bayan al-Niyyah \\ 'Inda Takbirat al-Ihram}

$\begin{array}{cccc}\text { Ts/27D/AS/BLAJ-SS/006 } & \text { Arab-Melayu } & \text { Prosa } & 19 \text { hal } \\ \text { Kertas Eropa } & 21 \times 16.5 & 15 \times 9 & 14 / \mathrm{hal}\end{array}$

\section{Pengarang}

Menurut Iskandar (1995: 433) pengarang naskah ini adalah Muhammad Zayn ibn al-Faqih Jaluluddin al-'Ashi pada 8 Muharram $1171 \mathrm{H} / 22$ September $1757 \mathrm{M}$.

\section{Penyalinan}

Pada 2 Rajab 1267 H (3 Mei 1851 M).

\section{Gambaran Isi}

Menjelaskan makna niat dalam takbiratulihram dengan pendekatan sufistik.

\section{Keterangan}

Teks keempat ini dalam Ikram, dkk. (2004: 285) berjudul "Syahrul 'lbad" tetapi penulis dengan jelas mendapati judul diatas ketika mengecek teksnya yang ditulis dari halaman 90 sampai halaman 108. Pada halaman 108 terdapat keterangan pemilik naskah, yaitu: “H. Ali bin H.Bu Palembang, kampung 21 llir Kapuran." Sedang di halaman lain tercantum "miliknya al-Hajj Muhammad Tayyib 26 Ilir." Awal teks keempat ini berbunyi, "Bismillahi al-Rahmani al-Rahimi. Dengan nama Allah yang Mahamurah lagi yang Mengasihani akan hamba-Nya. Aku memulai membaca kitab ini al-hamdu lillahi rabbi al-'alamin wa al-shalatu al-salamu 'ala sayyidina Muhammad wa 'ala alihi wa sashbihi ajma'in."

Bagian akhir teks ini adalah, “....pada Allah Ta'ala bahwa menyempurnai dengan Dia akan kehendak dan segala puji-pujian bagi Allah atas kesempurnaan pekerjaan hamba-Nya daripada tamat kitab ini dan memberi rahmat Allah Taala atas penghulu 
kita Nabi Muhammad dan atas keluarganya dan sahabatnya dan memberi sejahtera Allah subhanahu wa ta'ala atas sekalian mereka amin. Dan adalah selesai daripada menyurat kitab ini daripada nuskhah yang mubarak kepada dua hari bulan Rajab pada hari Sabtu waktu Dhuha fi sanah al-alf 1267 wa al-salam. Tamm."

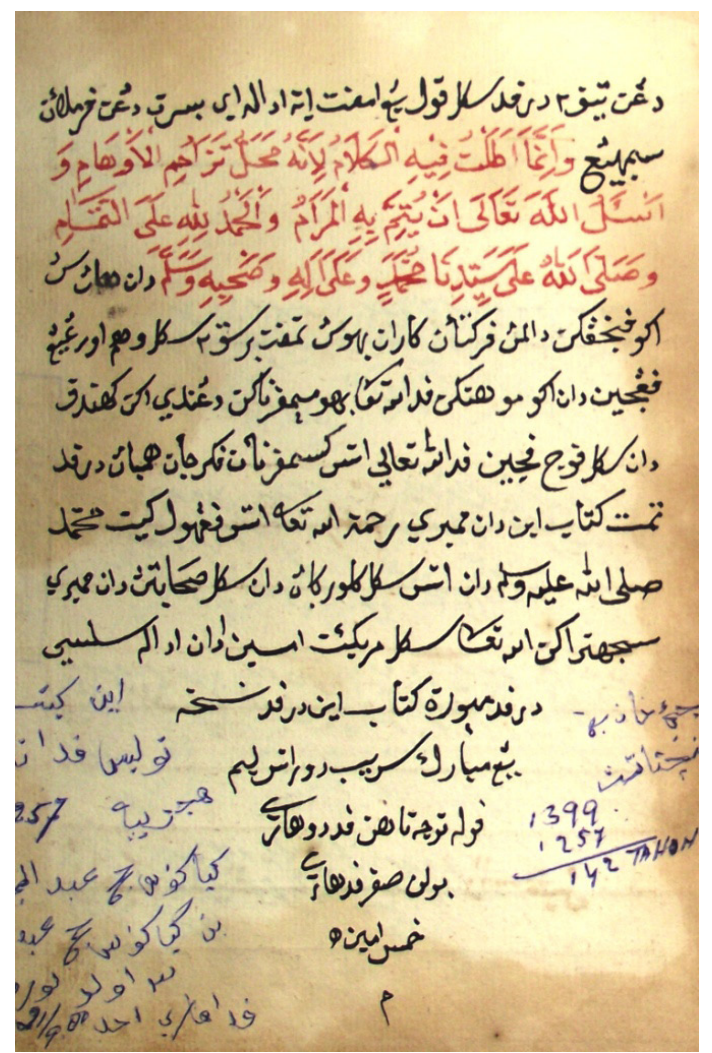

Kolofon: Kashfal-Kiram/Ts/27D/AS/BLAJ-SS/006. 


\section{Kitab Perhimpunan I'tiqad}

$\begin{array}{cccc}\text { Ts/31A/AS/BLAJ-SS/007 } & \text { Melayu } & \text { Prosa } & 9 \text { hal } \\ \text { Kertas Eropa } & 20.5 \times 16 & 16 \times 12.5 & 15 / \text { hal }\end{array}$

\section{Pengarang}

Haji 'Abdurrahim ibn Khalifah Mahdi

\section{Cap Kertas}

Propatria, NPANN....., TSTATNS, 1812 dan delapan garis tipis.

\section{Gambaran Isi}

Menjelaskan makna "tafakkaru fi khalqillah wa la tafakkaru fi dhatillah", yakni agar manusia mengenal dan mempelajari dirinya, bukan merenungkan Zat Allah; juga ada penjelasan tentang syahadah.

\section{Keterangan}

Naskah ini merupakan kumpulan teks yang setidaknya terdiri atas lima teks, yakni: Perhimpunan I'tiqad (1-9, 13-19); Fath al-Sirri (1947); Taqrir pada menyatakan yang bernama Allah (48-76); Bayan Tajalli (76-85); Faedah fi bayani al-fawa'idi al-lati tahsulu lidhdhikri al-mustaghraq bi kalami la ilaha illa Allah (86-91), Nuqil Zinat almuwahhidin dan wujudiah (91-98). Semua teks ditulis dengan tinta hitam, pada bagian tertentu yang dianggap penting tertulis lebih tebal.

Awal teks Perhimpunan i'tikad berbunyi, "Bismillahi al-Rahmani al-Rahimi. Kumulai kitab ini dengan nama Allah yang amat murah dalam dunia dan yang mengasihani hamba-Nya mukmin dalam akhirat."

Bagian akhir teksnya berbunyi, "Tammat al-Kitab Perhimpunan I'tiqad, hubaya jangan dilihatkan atau dipinjamkan kepada orang yang belum mengetahui dan belum ia mengambil kepada guru yang kamil, haram dilihat atau ditalu. Wallahu a'lam." 


\section{Fath al-Sirri}

$\begin{array}{cccc}\text { Ts/31B/AS/BLAJ-SS/008 } & \text { Melayu } & \text { Prosa } & 29 \text { hal } \\ \text { Kertas Eropa } & 20.5 \times 16 & 16 \times 12.5 & 15 / \text { hal }\end{array}$

\section{Pengarang}

'Abd al-Kariim (al-Jili?)

\section{Penerjemah}

Oleh Qadhi Nashiruddin di Kesultanan Johor.

\section{Cap Kertas}

Propatria, NPANN, TSTATNS, 1812 dan delapan garis tipis.

\section{Gambaran Isi}

Teks tasawuf falsafi yang menjelaskan makna sifat-sifat Allah, disertai dengan uraian tasawuf tentang makna sebuah hadis "Man 'arafa nafsahu faqad 'arafa Rabbahu'.

\section{Keterangan}

Teks kedua ini merupakan terjemahan dari karya Syeikh 'Abd alKarim, kemungkinan besar'Abd al-Karim al-Jili (w. 1421 M) berjudul Fath al-Sirri. Teks ini menurut penterjemah terdiri dari 15 bab, tetapi hanya 1 bab yang diterjemahkan. Teks Fath al-Sirri terdapat di halaman 19-47.

Awal teks Fath al-Sirri berbunyi, "Bismillahi al-Rahmani al-Rahimi. I'lam ini suatu tasnif Syeikh 'Abd al-Karim, maka adalah dinamainya tasnif itu Fath al-Sirri yakni yang membukakan pada rahasia agama mulya, daripada bahasa Arab bercampur dengan bahasa Parisi."

Bagian akhir teksnya berbunyi, "al-'Ilmu 'allamani, 'ilm al-qalb wa huwa 'ilm Allah, wa fi 'ilm bi al-lisani wa huwa 'ilm bi al-wahyi, ma ja'a Jibrilu 'an hadratillah Ta'ala ila al-nabiyyi Salla Allahu 'alayhi wa sallama, tammat al-kalam, amin thumma amin, tm." 


\section{Taqrir pada Menyatakan yang Bernama Allah}

$\begin{array}{cccc}\text { Ts/31C/AS/BLAJ-SS/009 } & \text { Melayu } & \text { Prosa } & 29 \text { hal } \\ \text { Kertas Eropa } & 20.5 \times 16 & 16 \times 12.5 & 15 / \text { hal }\end{array}$

\section{Cap Kertas}

Propatria, NPANN, TSTATNS, 1812 dan delapan garis tipis.

\section{Gambaran Isi}

Menjelaskan makna sifat Allah yang masing-masing dihubungkan dengan af'al-Nya, kemudian penjelasan a'yan al-thabitah, kemudian diakhiri pembagian qarb al-fara'id dan qarb nawafil.

\section{Keterangan}

Teks Taqrir pada menyatakan yang bernama Allah ada di halaman 48-76.

Awal teks Taqrir berbunyi, "Bismillahi al-Rahmani al-Rahimi. Dengan nama Allah jua kumulai nuqil ini ini Yang Amat Murah, yang amat Mengasihani, al-hamdu lillahi al-ladhi wahdah, segala puji-pujian bagi Allah Tuhan Yang Esa, wa al-shalat wa al-salamu 'ala man la nabiyya ba'dah."

Bagian akhir teks Taqrir berbunyi, "Dan wujud idhafi itu dikatakan khaliq dan makhluq, maka daripada idafah ia kepada a'yan thabitah dikatakan ia makhluk, dan daripada pihak ia idafah kepada haq Ta'ala, maka yaitu Khaliq namanya. Wallahu a'lam, amin.tm." 


\section{Bayan Tajalli}

$\begin{array}{cccc}\text { Ts/31D/AS/BLAJ-SS/010 } & \text { Melayu } & \text { Prosa } & 10 \mathrm{hal} \\ \text { Kertas Eropa } & 20.5 \times 16 & 16 \times 12.5 & 15 / \mathrm{hal}\end{array}$

\section{Pengarang}

'Abd al-Ra'uf al-Jawi al-Fanshuri (w. 1693 M).

\section{Cap Kertas}

Propatria, NPANN, TSTATNS, 1812 dan delapan garis tipis.

\section{Gambaran Isi}

Menjelaskan makna i'tikat tauhid yang sempurna yaitu "laysa kamithlihi shay'un wa lahu kullu shay"' yang merupakan inti pandangan wujudiyah dan wahdatul wujud menurut 'Abd al-Ra'uf al-Fanshuri, kemudian juga penjelasan tentang mati idhthirari dan ikhtiyari, dan kalimat zikir nafi ithbat sebagai zikir paling afdhal ketika sakaratul maut. Hal terakhir membantah ajaran sakaratul maut dalam naskah Jawi.

\section{Keterangan}

Teks Bayan Tajalli ada di halaman 76-85.

Awal teks berbunyi, "Bismillahi al-Rahmani al-Rahimi. al-hamdu lillahi wahdah, wa al-salatu wa al-salamu 'ala man la nabiyya ba'dahu. Amma ba'du, adapun kemudian daripada itu, maka ketahui olehmu hai talib, bahwasanya asal i'tiqad yang sempurna itu mengi'tiqadkan bahwa Haq Ta'ala itu "laysa kamithlihi shay'un wa lahu kullu shay"' Bagian akhir teks berbunyi, "Sebermula segala alamat yang telah tersebut itu tiada lazim, kerana mati itu tiada dengan ikhtiyar. Wallahu a'lam bi al-shawab wa ilayhi al-marji'u wa al-ma'ab. Tammat al-kitab bi 'aunillahi al-Malik al-Wahhab." 


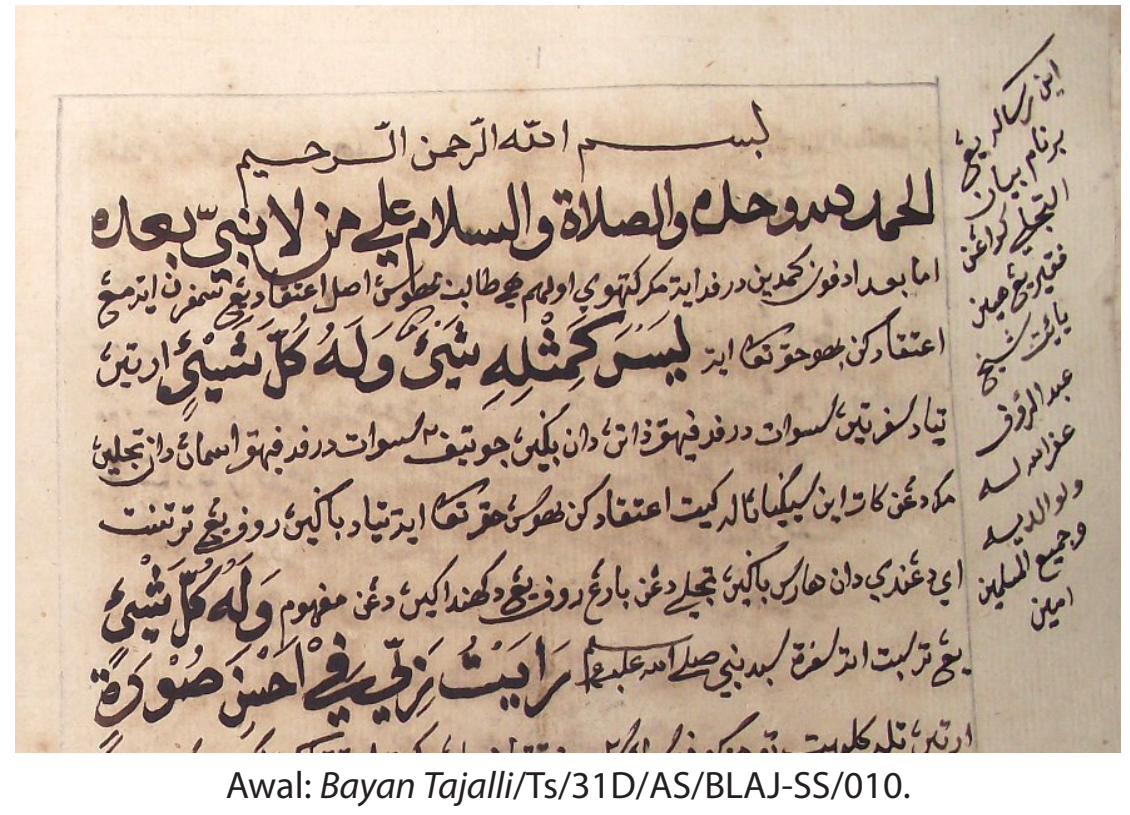


Fa'idah fi Bayan al-Fawa'id al-Lati Tahsulu Lidzdzikri alMustahgraq bi Kalami la Ilaha Illa Allah

$\begin{array}{cccc}\text { Ts/31E/AS/BLAJ-SS/011 } & \text { Melayu } & \text { Prosa } & 6 \text { hal } \\ \text { Kertas Eropa } & 20.5 \times 16 & 16 \times 12.5 & 15 / \mathrm{hal}\end{array}$

\section{Cap Kertas}

Propatria, NPANN, TSTATNS, 1812 dan delapan garis tipis.

\section{Kolofon}

"1257 kepada "25" bulan Jumadil Akhir (14 Agustus 1841 M) malam sabtu telah selesailah menyurat ini kitab. Amin, thumma amin."

\section{Gambaran Isi}

Menjelaskan manfaat zikir nafi ithbat bagi orang yang mengamalkannya secara betul dan konsekuen. Di antara manfaatnya disebutkan bersikap zahid, tawakkal, malu dan ta'zim, ghina, faqir, dan ithar.

\section{Keterangan}

Teks Fa'idah ada di halaman 86-91. Teks merupakan kutipan dari kitab 'Umdat al-Muhtajin karya 'Abd al-Ra'uf al-Jawi al-Fanshuri. Awal teks Fa'idah berbunyi, "Fa'idah fi bayan al-fawa'id al-lati tahsulu lidhdhikri al-mustaghraq bi kalami la ilaha illa Allah. Ini suatu faedah pada menyatakan segala faedah yang diperoleh bagi orang yang zikir, yang karam ia dengan kalimat "la ilaha illa Allah."

Bagian akhir teks berbunyi, "Tetapi seyogyanya orang yang mengerjakan zikir itu, jangan dimaksudkan dengan zikir itu, lain daripada wujud Allah. Dan apabila diniatkannya akan yang lain daripada wajah Allah, maka yaitu mahjub. Wa billahi al-tawfiq. Wallahu a'lam. Manqul min kitab 'umdat al-muhtajin.tm." 


\section{Wujudiyah}

$\begin{array}{cccc}\text { Ts/31F/AS/BLAJ-SS/012 } & \text { Melayu } & \text { Prosa } & 8 \text { hal } \\ \text { Kertas Eropa } & 20.5 \times 16 & 16 \times 12.5 & 15 / \text { hal }\end{array}$

\section{Cap Kertas}

Propatria, NPANN, TSTATNS, 1812 dan delapan garis tipis.

\section{Gambaran Isi}

Terdiri atas beberapa teks singkat yang menjelaskan berbagai tema yang khas tasawuf falsafi wujudiyah, seperti: makna la ta'ayyun dan arti sebuah hadis bahwa tidak ada yang benar-benar mengenal Allah kecuali Dia sendirinya. Makna dan hubungan 'ilm, wujud, shuhud, dan nur; ahadiyah, 'asyiq dan ma'syuq, macam-macam nafsu, dan sebagainya. kutipan teks pertama disebut dikutip dari Zinat al-Muwahhidin.

\section{Keterangan}

Teks Wujudiyah ada di halaman 91-98.

Awal teks berbunyi, "Bismillahi al-Rahmani al-Rahimi. Ketahui olehmu zat Allah Ta'ala dinamai ahlus-suluk "la ta'ayyun", maka dinamai la ta'ayyun karena budi dan bicara, ilmu dan ma'rifat kita tiada lulus kepadanya. Jangankan 'auliya dan insan pun heran oleh-Nya itu. Maka Sabda Nabi Shalla Allah 'alayhi wa sallama "Subhanaka ma 'arafnaka haqqa ma'rifatik."

Sedangkan teks akhirnya berbunyi, "Maka kata adalah seorang syari'at itu ghani, tiada amat "damping" pada Tuhan-nya, netiasa ia munajat tetapi adalah baik siksa atas orang shalat belum tau akan Tuhan-nya. Wallahu a'lam bi al-shawab. Tammat al-kalam." 


\section{Zuhrat al-Murid fi Bayan Kalimati al-Tawhid}

$\begin{array}{cccc}\text { Ts/46/AS/BLAJ-SS/013 } & \text { Melayu } & \text { Prosa } & 60 \text { hal } \\ \text { Buku bergaris } & 21 \times 16 & 15 \times 12 & 10 / \text { hal }\end{array}$

\section{Pengarang}

'Abd al-Shamad al-Jawi al-Falimbani.

\section{Penulisan}

Makkah, $1178 \mathrm{H} / 1764 \mathrm{M}$

\section{Penyalin}

Husayn bin Abu Bakar Ahmad Ba Sya'aib.

\section{Penyalinan}

Ahad, 20 Jumadilawwal 1339 H (30 January 1921 M).

\section{Cap kertas}

\section{Gambaran Isi}

Menguraikan ilmu mantiq dan ushuluddin yang dipelajari dari gurunya, Syeikh 'Abd al-Mun'im al-Damanhuri al-Misri, seorang ulama Mesir yang berkunjung ke Mekkah musim haji tahun itu.

\section{Keterangan}

Naskah terdiri atas 60 halaman. Ditulis dengan spasi renggang dengan 11 baris per halaman, ada garis panduan. Sebagian halaman diberi nomor halaman dengan huruf Arab di tengah sebelah atas. Teks ditulis dengan huruf Arab yang besar.

Bahan yang digunakan kertas bergaris. Kondisi kertas di bagian bawah banyak yang buram karena tinta yang luntur. Tulisan berwarna hitam dan sebagian ada yang menembus kertas sehingga sulit dibaca. Ada beberapa halaman yang bergambar, 
yaitu pada halaman 58 dan 60 yang berbentuk hitung-hitungan dalam segiempat, dan bintang yang dibentuk dari kata-kata yang ditulis seperti kaligrafi.

Awal teksnya berbunyi, "Bismillahi al-rahmani al-rahimi. Kumulai risalah ini dengan nama Allah yang amat murah lagi amat mengasihani akan hamba-Nya. Alhamdu lillahi al-wahidi al-ghaffar wa afdhalu al-salati wa al-salami 'ala sayyidina Muhammad almukhtar."

Bagian akhir teksnya berbunyi, "Wa shalla Allah 'ala sayyidina Muhammadin wa 'ala alihi wa shahbihi ajma'in. Al-hamdu lillahi rabb al-'alamin. Dan telah memberi rahmat Allah Ta'ala atas penghulu kita Nabi Muhammad Shalla Allahu 'alayhi wa sallama, dan atas keluarganya dan atas sahabatnya sekalian. Amin." 


\section{'Umdat al-Mu'tajin}

Ts/53A/AS/BLAJ-SS/014

Kertas Eropa
Melayu

$21 \times 16.5$
Prosa

$14.5 \times 12$
70 hal

$15 /$ hal

\section{Pengarang}

'Abd al-Ra'uf al-Jawi al-Fansuri (w. 1693 M).

\section{Penulisan}

Ditulis pada masa pemerintahan Sultanah Shafiatuddin Shah (1641-1675 M).

\section{Cap Kertas}

Tiga bulan sabit berjajar

\section{Gambaran Isi}

Penjelasan tentang ajaran tasawuf dan amalan tarekat. Pada bagian akhir dari naskah ini terdapat silsilah guru 'Abd al-Ra'uf dalam tarekat Syattariyah dan Qadiyiyah, serta nama-nama yang menjadi gurunya ketika belajar di beberapa daerah di Timur Tengah.

\section{Keterangan}

Kondisi kertas sudah rapuh. Warna sudah kehitam-hitaman karena usia dan jamur. Tulisan menggunakan tinta hitam dan merah pada rubrikasi. Teks di separoh halaman akhir sudah tidak terbaca. Kemungkinan bagian akhir teks ini terlepas. Naskah ini tampak menggunakan kertas yang berbeda dengan kumpulan teks berikutnya yakni 'Urwah al-Wuthqa dan Ratib Samman (71-174). Pada halaman pertama terdapat iluminasi berbentuk floral yang sangat menarik dengan warna-warni, yang salah satunya dengan warna emas; diduga kuat bahwa naskah ini dahulunya merupakan koleksi Keraton Palembang. Teks ditulis dalam kotak garis tepi.

Awal teks yang tertulis, "Bismillah al-Rahman al-Rahim. Al-hamdu lillahi rabb al-'alamin, wa al-shalatu wa al-salamu 'ala sayyidina Muhammadin, wa'ala alihi wa shahbihiajma'in, artinya dengan nama Allah yang amat murah, lagi yang amat mengasihani hambanya yang mu'min di dalam negeri akhirat." 


\begin{tabular}{cccc}
\multicolumn{4}{c}{ Al-Urwah al-Wuthqa dan Ratib Samman } \\
Ts/53B/AS/BLAJ-SS/015 & Melayu & Prosa & $102 \mathrm{hal}$ \\
Kertas Eropa & $21 \times 16.5$ & $14.5 \times 12$ & $15 / \mathrm{hal}$
\end{tabular}

\section{Pengarang}

Abd al-Shamad al-Jawi al-Falimbani.

\section{Penyalin}

Kgs. H. Ma'ruf ibn Hasan al-Din

\section{Penyalinan}

Makkah, 6 Muharam 1205 H (15 September 1790 M).

\section{Cap Kertas}

Bulan sabit dan tulisan CANSELL.

\section{Kolofon}

"Intahi, wa kataba al-faqir al-haqir Ma'ruf ibn Hasan al-Din fi Makkah al-Mukarramah pada enam hari bulan Muharram pada hari kamis $f$ hijrah al-Nabi sanah 1205."

\section{Gambaran Isi}

Berisi uraian talqin dan zikir dalam Tarekat Sammaniyah, bacaan musabbi'at al-'Asr, hizib Nawawi, hizib al-Bahri, dan ratib samman.

\section{Keterangan}

Teks yang berjumlah 102 halaman ini terbagi menjadi dua yakni 'Urwah al-Wuthqa (71-131) dan Ratib Samman (132-172). Namun, tampaknya teks ini merupakan satu kesatuan, karena berisi rangkaian ritual Tarekat Sammaniyah.

Teks awal 'Urwah al-Wuthqa berbunyi, "Kumulai risalah ini dengan nama Allah yang amat murah lagi mengasihani akan hambanya. 
Alhamdu lillahi haqqa hamdihi, segala puji tertentu bagi Allah yang sebenar-benarnya pujian-Nya."

Bagian akhir teks Urwah al-Wuthqa berbunyi, "Ini akhir risalah yang bernama Urwah al-wuthqa fi silsilat al-wali al-atqa sayyid alshaykh Muhammad ibn Sayyid al-Shaykh 'Abd al-Karim al-Samman al-Madani wa shalla Allahu 'ala sayyidina Muhammad wa alihi wa shahbihi wa sallam." 


\begin{tabular}{cccc}
\multicolumn{4}{c}{ Syarh 'Aqidat al-Iman } \\
Ts/69/AS/BLAJ-SS/016 & Melayu & Prosa & 307 hal \\
Kertas Eropa & $20 \times 15$ & $14.5 \times 10$ & $15 / \mathrm{hal}$
\end{tabular}

\section{Pengarang}

Ibrahim ibn Ibrahim al-Laqani (w. 1041 H/1631/32 M).

\section{Cap Kertas}

Singa bermahkota

\section{Gambaran Isi}

Menguraikan seluk beluk ilmu tauhid-tasawuf, menjelaskan sifat dua puluh, diawali dengan penjelasan makna kalimat "basmalah" dan hamdalah." Pembagian tiga ilmu pokok: tauhid, fiqih dan tasawuf; macam-macam motivasi seseorang beribadah, baik karena kepentingan dunia, akhirat, maupun semata-mata karena Allah.

\section{Keterangan}

Kondisi kertas di separoh bagian akhir sudah rapuh. Warna sudah kehitam-hitaman karena usia dan jamur. Tulisan berwarna hitam dan merah pada rubrikasi. Teks bagian-bagian akhir sudah tak terbaca, termasuk bagian kolofon. teks merupakan syarah Jawi atas kitab Mukhtashar Jawhar al-Tawhid dan diberi nama Sharh 'Aqidat al-Iman.

Teks awalnya berbunyi: "Bismillahi al-rahman al-rahim, al-hamdu lillahi, wa shalla Allahu 'ala khayri khalqihi Muhammadin wa 'ala alihi wa shahbihi. Wa ba'du, kemudian dari itu maka inilah syarah yang latif atas Mukhtashar Jawhar Tauhid namanya." 


\section{Kitab pada Menyatakan Ilmu Hakikat}

Ts/43/AS/BLAJ-SS/017

Buku Tulis

\author{
Melayu
}

$20 \times 15$
Prosa

$16.5 \times 12$
30 hal

$12 /$ hal

\section{Pemilik}

Abdul Khaliq Penghulu

\section{Penulisan}

25 Jumadil Awwal 1323 H (28 Juli 1905 M)

\section{Kolofon}

"Ini kitab muqaranah sakaratul maut yang punya saya nama 'Abd alKhaliq Penghulu h-d-'-w-y-."'

\section{Gambaran Isi}

Penjelasan tentang muqaranah menjadi empat, yakni syahadah, fana af'al, fana asma, dan fana sifat. Muqaranah-muqaranah itu terjadi ketika takbiratul ihram, sakaratul maut, dan wahdat al-zat.

\section{Keterangan}

Kondisi kertas mulai rapuh. Tinta menggunakan warna hitam. Teks cukup jelas untuk dibaca. Naskah tanpa sampul luar. Halaman kosong ada di 19 dan 20. Teks awalnya berbunyi: "Bismillahi alrahman al-rahim. Al-hamdu lillahi rabb al-'alamin, wa al-'aqibatu li al-muttaqina wa al-salatu wa al-salamu 'ala sayyidina Muhammadin shalla Allahu 'alayhi wa sallama. Amma ba'du, dan adapun kemudian daripada itu, maka inilah kitab pada menyatakan ilmu hakikat." Sedangkan teks akhir, berbunyi:"Dan adapun yang menutupi malu itu hawa nafsu yang jahat, dan yang menutupi ilmu itu sangkasangka, dan yang (menutupi) iman itu dusta, dan yang menutupi akal itu nafsu, demikian adanya. Wa allahu a'lam bi al-shawab." 


\section{'Umdat al-'Akidah fi Tahriri Kalimat al-Syahadah}

$\begin{array}{cccc}\text { Ts/17/41/AS/BLAJ-SS/018 } & \text { Melayu } & \text { Prosa } & 74 \text { hal } \\ \text { Kertas Eropa } & 21.5 \times 17 & 15 \times 10.5 & 17 / \text { hal }\end{array}$

\section{Penerjemahan}

Senin, 21 Rabiulakhir 1269 H (1 February 1853 M).

\section{Kolofon}

"Maka adalah disudahkan oleh faqir yang menterjemahkan risalah ini pada hijrah Nabi shalla Allahu 'alayhi wa sallama seribu dua ratus enam puluh sembilan pada tahun dal akhir kepada selikur hari bulan Rabiulakhir pada hari Isnaen pada waktu jam pukul delapan adanya, 1269."

\section{Gambaran Isi}

Teks tasawuf falsafi, menguraikan i'tiqad, menjelaskan makna dua kalimat syahadat, dan pentingnya seseorang mengetahui makna kalimat syahadat sebelum seseorang menjalankan shalat dengan sebaik-baiknya.

\section{Keterangan}

Naskah ini dalam koleksi Kms. Andi Syarifuddin terdapat dua, yakni Ts/17/AS dan Ts/41/AS. Kedua koleksi ini mengalami kerusakan, tintanya memudar, juga terkena ngengat dan jamur. Bahkan untuk teks Ts/17/AS teks separoh akhir sama sekali tidak bisa dibaca.

Teks awalnya, "Bismillahi al-rahman al-rahim, dengan nama Allah aku memulai membaca risalah ini; ialah Tuhan yang amat murah di dalam negeri dunia ini, pada memberi rizki akan segala hambanya daripada manusia dan jin, dan binatang laut dan darat, lagi yang amat mengasihi akan segala hambanya yang beriman daripada manusia dan jin di dalam negeri akhirat." Sedangkan teks akhirnya, "Maka menyebut kalimat-kalimat itu banyak faedahnya hanya 
pada pengetahuannya menyebut kalimat itu zikir yang "senatu" lagi ringannya atas lidah tetapi amat berat pada timbangannya; intahi al-kalam, bi al-khayr wa ma'a al-salam." 


\section{'Aiyat al-Rahman fi Bayani Qawa'id al-Iman}

$\begin{array}{cccc}\text { Ts/2/AS/BLAJ-SS/019 } & \text { Melayu } & \text { Prosa } & 74 \text { hal } \\ \text { Kertas Eropa } & 21 \times 17.5 & 17 \times 12 & 19 / \mathrm{hal}\end{array}$

\section{Pengarang}

Muhammad Azhari ibn 'Abdullah al-Falimbani (1811-1874).

\section{Penulisan}

Makkah, 1259 H (1843 M)

\section{Cap Kertas}

Garden of Holland with Britanni-like Maid.

\section{Kolofon}

"Alamat kitab'Athiyah al-Rahman, yang empunya Nyimas Unek binti Kemas Haji Abang al-Jawi Palembang di dalam Kampung Sepuluh Sembilan Ilir dekat masjid. Barangsiapa meminjamnya minta pulangkan segera kepada (empunya) sebab payah menyuratnya dan jikalau tuan yang membacanya jangan dekat pelita sebab kalau kena minyak adanya."

\section{Gambaran Isi}

Naskah menguraikan seluk beluk ilmu tauhid. Bagian awal teks tentang pujian-pujian kepada Tuhan. Lalu, menguraikan tentang kewajiban beriman bagi laki-laki dan wanita yang baligh, menjelaskan tentang sifat dua puluh yang wajib bagi Allah dan dalil-dalilnya."

\section{Keterangan}

Naskah merupakan catatan selama mutala'ah kitab matan alSanusi dan hasyiah Syeikh Ibrahim al-Bajuri. Bunyi teks awalnya adalah, "Bismillahi al-rahman al-rahim, dengan nama Allah Tuhan yang amat murah, lagi yang amat mengasihani akan hambanya, 
aku memulai kitab ini, al-hamdu lillahi al-ahada al-ladhi laysa lahu walidun wa la walada." Teks akhirnya berbunyi, "wa shalla Allahu 'ala khayri khalqihi sayyidina Muhammadin wa alihi wa shahbihi, dan mudah-mudahan memberi rahmat oleh Allah Ta'ala atas sebaikbaik hambanya, penghulu kaya Nabi Muhammad shalla Allahu 'alayhi wa salam, dan atas segala keluarganya dan sahabatnya." 


\section{Mir'ah al-Haqq}

Ts/42/AS/BLAJ-SS/020

Kertas Eropa
Melayu

$20 \times 17$
Prosa

$15 \times 11$
14 hal

$15 /$ hal

\section{Gambaran Isi}

Naskah tasawuf falsafi. Setelah mengawali dengan muqaddimah, penulis mengemukakan pembahasan mendalam tentang hakikat dan ma'rifat, disebutkan uraian pembagian hati menjadi hati sanubari dan nurani, martabat muqaranah, fana', dan baqa'.

\section{Keterangan}

Kondisi kertas sudah rapuh. Warna sudah kehitam-hitaman dan berlobang dari halaman 2-14. Teks halaman akhir tak bisa dibaca. Tinta berwarna hitam dan merah pada rubrikasi. Teks disusun berdasarkan karya Ibn 'Arabi, bab al-tasawuf; al-Raniri, Asrar alInsan; dan Syeikh 'Abd al-Qadir al-Jaylani, wahdat al-wujud. Teks awalnya berbunyi, "Bismillahi al-rahman al-rahim, al-hamdu lillahi rabb al-'alamin, wa al-shalatu wa al-salamu 'ala rasulillahi shalla Allahu 'alayhi wa sallama. Wa ba'du, adapun kemudian daripada itu maka inilah suatu risalah yang simpan pada menyatakan tauhid dan ma'rifat." 


\section{Zad al-Muttaqin}

Ts/40A/AS/BLAJ-SS/021

Arab-Melayu

Prosa

7 hal

Kertas Eropa

$27 \times 17 \mathrm{~cm}$

$19.5 \times 13 \mathrm{~cm}$

20-23/hal

\section{Pengarang}

'Abd al-Shamad al-Jawi al-Falimbani

\section{Penyalinan}

Kamis, 7 Syawal 1285 H (21 Januari 1869 M).

\section{Kolofon}

"Wa kana al-faragh min nuskhah yaum al-khamis li sab'a al-yaum min shahri shawal fi tarikh sanah 1285 bi yadi al-faqir ila Allah al-ghani afqar al-'ibad wa aqsharahum 'ilman wa fahman, al-hajj Ma'ruf ibn al-marhum al-hajj Muhammad Hasyim, tm. ghafarallahu lahuma wa liwalidayhima, amin thumma amin amin."

\section{Cap Kertas}

Perisai

\section{Gambaran Isi}

Naskah tasawuf falsafi menjelaskan"khamsu kalimatin", lima kalimat kunci dalam paham wahdat al-wujud yaitu tiga macam fana dan dua macam baqa, kutipan dari kitab Lawa'ih karya 'Abd al-Rahman Jami tentang wujud al-hagq, dan penjelasan tentang makna zikir nafi ithbat.

\section{Keterangan}

Keterangan tentang judul naskah ini diperoleh dari pemilik naskah, Kms. Andi Syarifuddin, tidak ada keterangan judul dalam teks, tetapi di halaman satu jelas disebut nama 'Abd al-Samad al-Falimbani. Semua teks berbahasa Arab, kecuali kutipan dari Lawa'ih berbahasa Melayu. Teks ini tergabung sebelum teks 
Risalah karangan Shihabuddin ibn 'Abdullah. Teks awal berbunyi, "Bismillahi al-rahman al-rahim, wa bihi nasta'in, qala shaykhuna alarif billahi al-afrad al-manan mawlana al-shaykh 'Abd al-Shamad ibn 'Abd al-Rahman al-Jawi al-Falimbani khalifat al-qutb al-akwan mahbub al-rahman mawlana al-Shaykh Muhammad Samman alMadani." Sedangkan teks akhir sebelum kolofon adalah, "fa al-ula bihi an ya'khudhu dzalika 'anhu fainna al-kitabi hilatun al-fagid wa al-afkam farq bayna man ya'khudhu thariqatuhu 'an 'arif muhaqqiq li baladihi ila Allah, wa man ya'khudhu thariqatun min kitabi Allah. Wa al-hadi li al-shawab wa ilayhi al-marji'u wa al-ayyab wa al-taufik minhu wa biyadihi, intahi." 


\section{Risalah}

$\begin{array}{cccc}\text { Ts/40B/AS/BLAJ-SS/022 } & \text { Melayu } & \text { Prosa } & 10 \text { hal } \\ \text { Kertas Eropa } & 27 \times 17 \mathrm{~cm} & 19.5 \times 13 \mathrm{~cm} & 21-26 / \mathrm{hal}\end{array}$

\section{Pengarang}

Shihab al-Din ibn 'Abdullah

\section{Penyalinan}

Kamis, 7 Syawal 1285 H (21 Januari 1869 M).

\section{Cap Kertas}

Perisai

\section{Gambaran Isi}

Berisi kecaman terhadap penyelewengan dalam penghayatan tarekat. Demikian juga seruan agar ajaran wahdatul wujud dan/ atau martabat tujuh tidak dipelajari oleh kalangan mubtadi karena jika pemahamannya tidak benar akan menyebabkan kekafiran.

\section{Keterangan}

Keterangan tentang judul naskah ini diperoleh dari Drewes (1977: 88-98). Teks halaman 8-17 ini sama persis dengan teks yang telah ditranskripsi oleh Drewes dalam karya tersebut. Kecuali satu halaman terakhir yang memuat nama pengarang tidak ada. Teks ini berbahasa Melayu. Teks awal berbunyi, "Bismillahi al-rahman alrahim, al-hamdu lillahi rabb al-'alamin, wa shalla Allahu 'ala sayyidina Muhammadin wa alihi wa shahbihi ajma'in. Wa ba'du kemudian daripada itu maka inilah suatu risalah yang lathif lagi mukhtashar pada menyatakan ilmu tasawuf." Sedangkan teks akhir berbunyi, "Subhanaka rabbika rabb al-'Izzati 'amma yashifun, wa salamun 'ala al-mursalin wa al-hamdu lillahi rabb al-'alamin. wa shalla Allahu 'ala sayyidina Muhammadin wa alihi wa shahbihi ajma'in. Amin, amin. 


\section{Tuhfah al-Raghibin}

Ts/30/AS/BLAJ-SS/023

Melayu

Prosa

79 hal

Kertas Eropa

$20 \times 17 \mathrm{~cm}$

$16 \times 11 \mathrm{~cm}$

$17 /$ hal

\section{Pengarang}

Muhammad Arsyad al-Banjari (w. 1227 H/1812 M)

\section{Penulisan}

Tahun 1188 H (1774 M).

\section{Cap Kertas}

Lion in medallion: Concordia (3.0).

\section{Gambaran Isi}

Menguraikan akidah dan ketauhidan. Bagian awal naskah yang terbaca menguraikan hakikat keimanan yang benar, dan bila sebaliknya akan dianggap murtad.

\section{Keterangan}

Kondisi kertas sudah rapuh. Warna sudah kehitam-hitaman karena faktor usia dan jamur. Tulisan berwarna hitam dan rubrikasi tinta merah. Teks sebagian besar sudah tidak terbaca. Halaman awal dan akhir tidak ada. Teks halaman awal yang terbaca: "....Dan ma'rifah dan asna'u lahu risalatan mukhtasharah .... fi bayani haqiqat alimani wa ma yufsiduhu min al-aqwal .......bahwa aku pun buatkan baginya suatu......... Sedangkan bagian akhir yang terbaca adalah "Sekali peristiwa ditanyai orang Imam radiyallahu 'anhu, daripada mazhab Ahlussunnah wal Jama'ah maka jawab bahwa mazhab Ahlussunnah wal Jama'ah itu yang tiada Khariji dan tiada Rafidhi, dan tiada Jabariah dan tiada Qadariah, dan tiada Tasybih......" 


\section{Matnu al-Daurah}

$\begin{array}{cccc}\text { Ts/7/AS/BLAJ-SS/024 } & \text { Melayu } & \text { Prosa } & 53 \text { hal } \\ \text { Kertas Eropa } & 33.5 \times 21 \mathrm{~cm} & 30 \times 13 \mathrm{~cm} & 19 / \mathrm{hal}\end{array}$

\section{Pengarang}

Kgs. H. 'Abd al-Shamad b. Kgs. H. Shadar

\section{Penulisan}

Palembang, Senin, 4 Jumadilakhir 1293 H (27 Juni 1876 M).

\section{Kolofon}

"Ditulis pada empat hari bulan Jumadil Akhir hari Isnin jam dua, tahun 1293 Hijriah, katabahu al-faqir Kiagus Haji 'Abd al-Shamad bin Kiagus Haji Shadar yang ditulis di kampung 19 ilir."

\section{Cap Kertas}

\section{Gambaran Isi}

Merupakan naskah tasawuf akhlaqi. Naskah ini menguraikan seluk beluk penjelasan sifat wajib bagi Allah dengan pendekatan sufistik.

\section{Keterangan}

Tulisan menggunakan tinta warna hitam, sedangkan rubrikasi menggunakan tinta warna merah. Kondisi naskah sudah rusak, tulisan sulit untuk dibaca. 


\section{Sair al-Salikin}

Ts/41/AS/BLAJ-SS/025

Kertas Eropa

$$
\text { Melayu }
$$

$23.5 \times 17 \mathrm{~cm}$

Prosa

$72 \mathrm{hal}$

$15 \times 9.5 \mathrm{~cm}$

$19 /$ hal

\section{Pengarang}

'Abd al-Samad al-Jawi al-Falimbani (1736-1818).

\section{Penulisan}

Mekkah, 1193-1203 H/1778-1788 M.

\section{Cap Kertas}

Bulan tersenyum di dalam Perisai

\section{Gambaran Isi}

Naskah tentang tasawuf akhlaki, menguraikan seluk-beluk ilmu tasawuf, yang diterjemahkan oleh Syeikh 'Abd al-Samad al-Jawi al-Falimbani dari kitab Mukhtashar Ihya 'Ulum al-Din karya alGhadzali. Kitab ini terdiri dari empat jilid, isinya tentang syaratsyarat kesempurnaan ibadah seorang salik.

\section{Keterangan}

Naskah tidak lengkap 


\section{Asrar al-Insan fi Ma'rifat al-Ruh wa al-Rahman \\ Ts/9/NUK/BLAJ-SS/026 \\ Arab-Melayu \\ Prosa \\ 166 hal \\ Kertas Eropa \\ $20.5 \times 16.5$ \\ $16 \times 10$ \\ $17 /$ hal}

\section{Pengarang}

Nur al-Din ibn 'Ali ibn Hasanji ibn Muhammad Hamid al-Raniri.

\section{Penulisan}

Masa Sultanah Taj al-'Alam Safiyat al-Din Shah (1641-1661 H).

\section{Penyalinan}

27 Sya'ban 1252 H (7 December 1836 M).

\section{Cap Kertas}

Propatria, Garden of Holland (2.0).

\section{Gambaran Isi}

Teks berisi ajaran tasawuf Syeikh Nur al-Din al-Raniri yang membicarakan tentang ruh dan ketuhanan, untuk "memadamkan segala bid'ah dan dalalah (kesesatan)"; ditulis pada masa Sulthanah Taj al-'Alam Shafiat al-Din zillu Allah fi al-'alam". Teks juga menguraikan antara lain tentang zat dan sifat-sifat Allah, nama-nama Allah, konsep-konsep filosofis a'yan thabitah, a'yan kharijiyyah, ruh idhafi, dan lain-lain.

\section{Keterangan}

Teks menggunakan tinta warna hitam dan merah digunakan untuk teks berbahasa Arab. Kondisi naskah kurang baik, namun masih terbaca jelas kecuali 5 halaman di tengah yang telah rusak. Bagian tepi naskah sudah terkikis. Terdapat beberapa pias yang bertulis dengan bentuk tulisan yang sama dengan teks. Terdapat skema berbentuk " $\mathrm{H}$ " yang merupakan kiasan hubungan antara martabat dan zat. Di halaman awal terdapat nama penyusun, Nur al-Din al- 
Raniri, sebagai berikut: "Syeikh Nur al-Din ibn 'Ali ibn Hasanji ibn Muhammad Hamid nama bangsanya, Raniri nama negerinya".

Awal teks terbaca, "Bismillah al-Rahman al-Rahim. Al-hamdu lillahi al-ladhi azhara kanzahu al-makhfiya min ma'lumati; segala puji bagi Allah...". Teks ditutup dengan kutipan ayat Al-Qur'an surat an-Nur $: 24$. 


\section{Fath al-Sirri II}

Ts/12A/NUK/BLAJ-SS/027

$$
\text { Melayu }
$$

Prosa

53 hal

Kertas Eropa

$20.5 \times 17 \mathrm{~cm}$

$15 \times 11 \mathrm{~cm}$

$13-16 /$ hal

\section{Pengarang}

'Abd al-Karim (al-Jili?)

\section{Penerjemah}

Oleh Qadhi Nashiruddin di Kesultanan Johor.

\section{Cap Kertas}

Propatria dan gambar mahkota.

\section{Gambaran Isi}

Teks tasawuf falsafi yang menjelaskan makna sifat-sifat Allah, disertai dengan uraian tasawuf tentang makna sebuah hadis "Man 'arafa nafsahu faqad 'arafa Rabbahu.."

\section{Keterangan}

Teks ini merupakan terjemahan dari karya Syeikh 'Abd al-Karim, kemungkinan besar 'Abd al-Karim al-Jili (w. 1421 M) berjudul Fath al-Sirri. Teks ini menurut penterjemah terdiri dari $15 \mathrm{bab}$, tetapi hanya 1 bab yang diterjemahkan. Teks Fath al-Sirri terdiri atas 53 halaman.

Awal teks Fath al-Sirri berbunyi, "Bismillahi al-Rahmani alRahimi. I'lam (ini suatu tasnif Syeikh 'Abd al-Karim), maka adalah dinamainya Fath al-Sirri (yakni yang membukakan pada rahasia agama mulya), daripada bahasa Arab bercampur dengan bahasa Parisi dipindahkannya oleh Qadi Nashiruddin bahasa Melayu dan tempatnya mengubahkan bahasa itu di dalam Negeri Johor."

Selain teks Fath al-Sirri juga terdapat dua teks lain, yakni Doa Ismu al-A'zam (lima halaman) dan Jadwal sembahyang berjama'ah (dua halaman). Total naskah terdiri atas 60 halaman. 


\section{Zikir Syeikh Muhammad Samman}

$\begin{array}{cccc}\text { Ts/13/NUK/BLAJ-SS/028 } & \text { Arab-Melayu } & \text { Prosa } & 36 \mathrm{hlm} \\ \text { Kertas Eropa } & 21 \times 17 \mathrm{~cm} & 16.5 \times 10 \mathrm{~cm} & 12 / \mathrm{hlm}\end{array}$

\section{Gambaran Isi}

Naskah ini berisi tata cara berzikir dan bacaan-bacaannya seperti yang diajarkan oleh Syeikh Muhammad Samman. Dimulai dengan membaca Astagfiru Allah al-gafur ar-rahim dua kali, kemudian membaca salawat, Allahumma salli 'ala Sayyidina Muhammadin wa alihi wa salim, kemudian membaca La ilaha illa Allah sambil menghayati artinya, dan seterusnya.

\section{Keterangan}

Naskah ini tanpa dijudul. Setelah dibaca isinya, naskah ini pantas diberi judul Zikir Syeikh Muhammad Samman. Naskah ini sudah tidak bersampul. Penomoran halaman tidak ada. Halaman-halaman disambungkan dengan kata alihan. Warna tinta hitam dan merah. Kondisi naskah telah rusak, berlubang, dan tidak lengkap.

Bagian depan naskah ini telah hilang Teks dimulai dengan silsilah tarekat seperti berikut, "...ibn Kemas Haji Abdullah ibn Kemas Haji Muhammad ibn Muhammad, ia mengambil daripada Tuan sayyid Hasib, ia mengambil daripada Syeikh Tayyib, ia mengambil daripada Syeikh Muhammad 'Aqil, ia mengambil daripada Syeikh Sadiq, ia mengambil daripada Qutub al-Akwan Mahbub ar-Rahman Sayyidi asy-Syeikh Muhammad ibn Abd al-Karim asy-Samman al-Madani." 


\section{Risalah Manaqib Syeikh Muhammad Samma al-Madani}

Ts/AMD/BLAJ-SS/029

Kertas Eropa

Melayu

$19 \times 13 \mathrm{~cm}$
Prosa

$15 \times 9 \mathrm{~cm}$
$37 \mathrm{hlm}$

13-16/hlm

\section{Penerjemah}

Syeikh Shodiq al-Madani

\section{Penerjemahan}

Tahun 1328 H (1910/11 M).

\section{Kolofon}

"Ini risalah Manaqib Syeikh Muhammad Samman al-Madani yang masyhur keramatnya maka Syeikh Shodiq al-Madani Kholifah Syeikh yang menterjemahkan dengan bahasa Melayu yang ditashihkan oleh Syeikh Muhammad Azhar al-Falimbani, Mudahmudahan Allah Ta'ala jadikan manfaat bagi sekalian orang Islam 1328."

\section{Cap Kertas}

\section{Gambaran Isi}

Berisi biografi Syeikh Muhammad Samman al-Madani, pendiri tarekat Sammaniyah, baik asal usul orang tuanya, pendidikannya dan karamat-karamatnya.

\section{Keterangan}

Naskah ini merupakan naskah hasil terjemahan, naskah aslinya dengan menggunakan bahasa Arab. Informasi ini ada pada kolofon naskah. Bahan untuk penjilidan naskah ini terbuat dari kertas karton berwarna coklat. Kondisi naskah bagus, demikian pula dengan kondisi teks. Pengikat beberapa kuras yang ada menggunakan benang berwarna putih. Teks menggunakan 
Bahasa Arab dan Jawi dengan jenis tulisan riq'ah. Garis panduan tidak dijumpai didalamnya. Penomoran halaman ada di atas teks. Tinta yang digunakan dalam tulisan adalah berwarna hitam. Teks pertama pada tulisan bismillah, terdapat iluminasi berupa floral. Kutipan awal teks, yakni pada halaman 2 adalah: "Bismillahirrahmanirrahim, Ahmad min manistafa min 'ibadihi man sya'a bil wilayati, yakni aku memuja akan Allah SWT yang Maha Mulia." Naskah ini dimiliki oleh genersi ke-4 yakni Masagus Aminuddin S.H. dari pemilik naskah sebelumnya dan didapatkan secara turuntemurun. 


\title{
6 \\ Kalelesi dan Katalogisasi KOLEKSI NASKAH TASAWUF DI PROPINSI BANTEN
}

\author{
Oleh: \\ Muhamad Rosadi
}

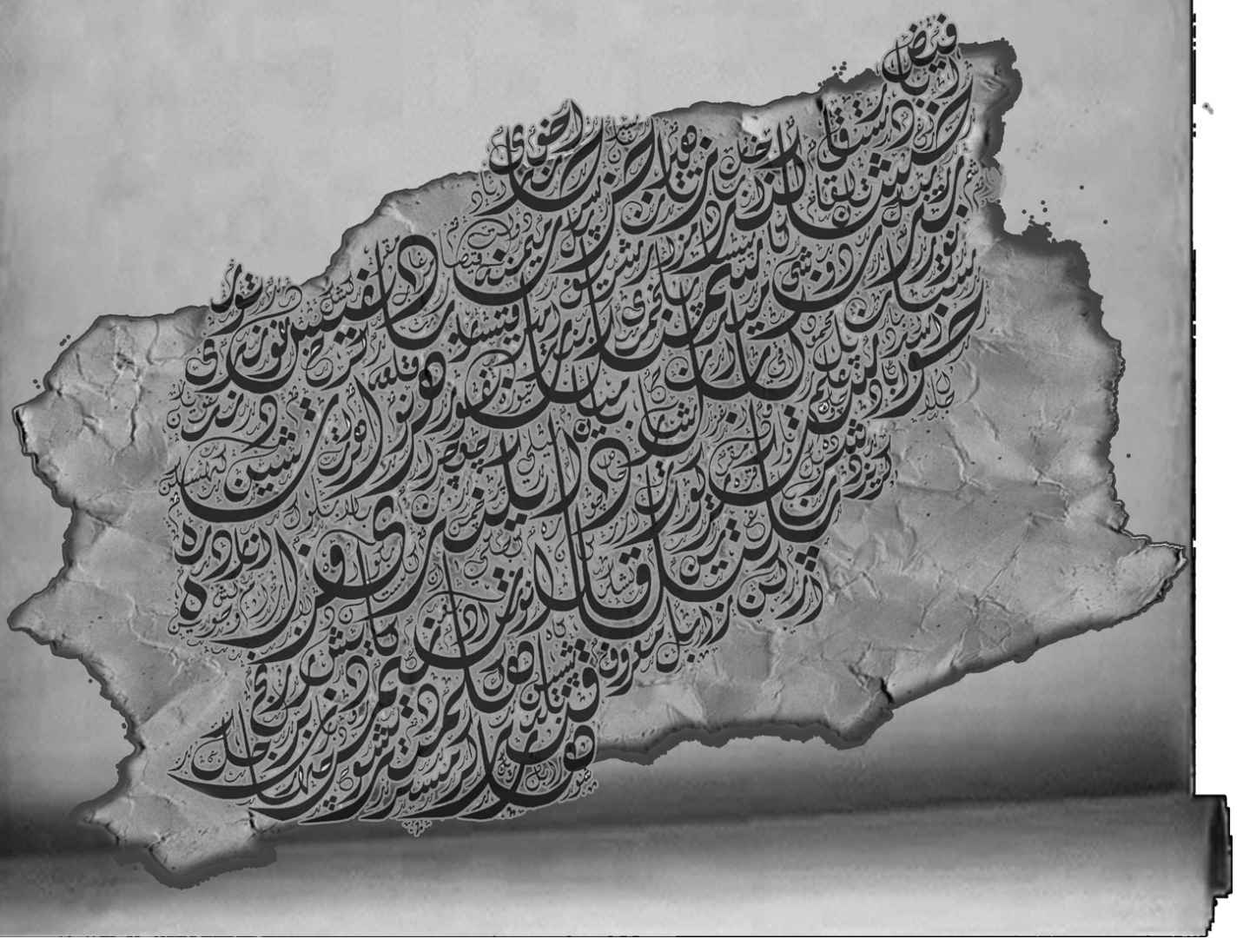




\section{Koleksi Balai Pelestarian Peninggalan Purbakala dan Sejarah Serang, Kecamatan Tirtayasa}

\section{Syu'bul Iman}

$\begin{array}{cccc}\text { Ts-1/BLAJ/2012 } & \text { Aks/Bhs Arab } & \text { Prosa } & 249 \mathrm{hlm} \\ \text { Kertas Eropa } & 21 \times 16,5 \mathrm{~cm} & 10,5 \times 15 \mathrm{~cm} & 13 \mathrm{baris} / \mathrm{hlm}\end{array}$

\section{Cap Kertas}

Estate Libertate Vryheit (2 Singa bermahkota memegang pedang bergagang mahkota)

\section{Keterangan}

Naskah Syu'bul Iman ini dicatat dengan nomor Ts-1/BLAJ/ 2012. Naskah yang tersimpan di Balai Pelestarian Peninggalan Purbakala dan Sejarah Serang Kecamatan Tirtayasa ini mempunyai kolofon yang berisi keterangan mengenai waktu penyalinan, yaitu pada hari Ahad tanggal 28 Rajab Tahun Dal $1279 \mathrm{H}$. Kondisi naskah yang disalin dengan aksara dan bahasa Arab ini cukup baik dan lengkap dengan warna tinta berwarna hitam dan merah.

\section{Gambaran Isi}

Teks ini berisi uraian dan penjelasan mengenai konsep keimanan dan keutamaan zikir. 


\section{Koleksi Tabrani, Kampung Gagas Selawe, Desa Onyam, Kecamatan Gunung Kaler}

\begin{tabular}{cccc}
\multicolumn{4}{c}{ Naskah Tasawuf } \\
Ts-2/BLAJ/2012 & Aks/Bhs Arab & Prosa & $55 \mathrm{hlm}$ \\
Kertas Eropa & $21 \times 16,5 \mathrm{~cm}$ & $10,5 \times 15 \mathrm{~cm}$ & $14 \mathrm{baris} / \mathrm{hlm}$
\end{tabular}

\section{Cap Kertas}

2 Singa bermahkota memegang pedang bergagang mahkota

\section{Keterangan}

Naskah tasawuf ini dicatat dengan nomor Ts-2/BLAJ/2012. Pemilik naskah ini adalah Ustadz Tabrani yang beralamat di Kampung Gagas Selawe, Desa Onyam, Kecamatan Gunung Kaler. Kondisi naskah yang ditulis dengan aksara dan bahasa Arab ini masih baik dan menggunakan tinta berwarna hitam.

\section{Gambaran Isi}

Naskah ini berisi uraian mengenai konsep dan istilah dalam ilmu tasawuf. 


\section{Qawa'id Dzikr}

$\begin{array}{cccc}\text { Ts-3/BLAJ } / 2012 & \text { Aks/Bhs Arab } & \text { Prosa } & 18 \mathrm{hlm} \\ \text { Kertas Eropa } & 21 \times 16,5 \mathrm{~cm} & 10,5 \times 15 \mathrm{~cm} & 16 \text { baris } / \mathrm{hlm}\end{array}$

\section{Cap Kertas}

2 Singa bermahkota memegang pedang bergagang mahkota

\section{Keterangan}

Naskah Qawa'id Dzikr ini dicatat dengan nomor Ts-3/BLAJ/2012. Pemilik naskah ini adalah Ustadz Tabrani yang beralamat di Kampung Gagas Selawe, Desa Onyam, Kecamatan Gunung Kaler. Kondisi naskah yang ditulis dengan aksara dan bahasa Arab ini masih baik dan menggunakan tinta berwarna hitam. Terdapat rubrikasi dengan tinta merah di awal teks.

\section{Gambaran Isi}

Naskah ini berisi uraian mengenai konsep dan istilah dalam ilmu tasawuf. 


\title{
Koleksi Tanjib, Desa Tersaba, Kecamatan Tanara, Kabupaten Serang
}

\author{
Doa dan Shalawat Rifa'iyah-Syatariyah \\ Ts-4/BLAJ/2012 Aks/Bhs Arab \\ Prosa \\ $256 \mathrm{hlm}$ \\ Kertas Eropa \\ $16 \times 10,5 \mathrm{~cm}$ \\ $7 \times 13,5 \mathrm{~cm}$ \\ 15 baris/hlm
}

\section{Cap Kertas}

\section{Keterangan}

Naskah Doa dan Shalawat Rifa'iyah Syatariyah ini dicatat dengan nomor Ts-4/BLAJ/2012. Naskah ini dikarang oleh Mohammad Ali Bin Sulaiman. Adapun pemilik naskah ini adalah Ustad Tanjib yang beralamat di Desa Tersaba Kecamatan Tanara Kabupaten Serang. Kondisi naskah cukup baik dan dapat dibaca. Naskah ini tanpa cover luar.

\section{Gambaran Isi}

Naskah ini berisi tentang berbagai macam doa dan shalawat yang diamalkan para pengikut Tarekat Rifa'iyah dan Syattariyah. 


\section{Koleksi Dimyati, Kampung Gembong, Desa Gembong, Kecamatan Balaraja, Kabupaten Tangerang}

\section{Martabat Tujuh}

$\begin{array}{cccc}\text { Ts-5/BLAJ/2012 } & \text { Aks/Bhs Arab } & \text { Prosa } & 31 \mathrm{Hlm} \\ \text { Dluwang } & 25 \times 16 \mathrm{~cm} & 15 \times 9,5 \mathrm{~cm} & 9 \text { baris } / \mathrm{hlm}\end{array}$

\section{Cap Kertas}

\section{Keterangan}

Teks Martabat Tujuh ini dicatat dengan kode Ts-5/BLAJ/2012. Teks ini berada dalam naskah milik Ustadz H. Dimyati yang beralamat di Kampung Gembong, Desa Gembong, Kecamatan Balaraja, Kabupaten Tangerang.

\section{Gambaran Isi}

Teks ini berisi uraian mengenai ajaran martabat tujuh, antara lain martabat ahadiyat, martabat wahidiyat dan martabat wahdaniyat. 


\section{Qawaid Shufiyah}

$\begin{array}{cccc}\text { Ts-6/BLAJ/2012 } & \text { Aks/Bhs Arab } & \text { Prosa } & 10 \mathrm{HIm} \\ \text { Dluwang } & 25 \times 16 \mathrm{~cm} & 15 \times 9,5 \mathrm{~cm} & 9 \text { baris } / \mathrm{hlm}\end{array}$

\section{Cap Kertas}

\section{Keterangan}

Teks Qawaid Shufiyah ini dicatat dengan kode Ts-6/BLAJ/2012. Teks ini berada dalam naskah milik Ustadz H. Dimyati yang beralamat di Kampung Gembong, Desa Gembong, Kecamatan Balaraja, Kabupaten Tangerang.

\section{Gambaran Isi}

Teks ini berisi uraian mengenai wujudul haq, ilmu haq, dan 'ilmu Ilahi. 


\section{Bayan Allah}

$\begin{array}{cccc}\text { Ts-7/BLAJ/2012 } & \text { Aks/Bhs Arab } & \text { Prosa } & 14 \mathrm{hlm} \\ \text { Dluwang } & 25 \times 16 \mathrm{~cm} & 15 \times 9,5 \mathrm{~cm} & 9 \text { baris } / \mathrm{hlm}\end{array}$

\section{Cap Kertas}

\section{Keterangan}

Teks Bayan Allah ini dicatat dengan kode Ts-7/BLAJ/2012. Teks ini terdapat dalam naskah milik Ustadz $\mathrm{H}$. Dimyati yang beralamat di Kampung Gembong, Desa Gembong, Kecamatan Balaraja, Kabupaten Tangerang.

\section{Gambaran isi}

Teks ini berisi uraian mengenai ma'rifatullah dan wahdaniyyat. 


\section{Koleksi Atiqoh, Kampung Gelereng, Desa Gelereng, Kecamatan Ciwandan, Kota Cilegon}

\section{Wawacan Murtasyid}

$\begin{array}{cccc}\text { Ts-8/BLAJ/2012 } & \text { Aks/Bhs } & \text { Prosa } & \text { Hlm } \\ \text { Kertas HVS } & 10 \times 18 \mathrm{~cm} & 9 \times 16 \mathrm{~cm} & 14 \text { baris } / \mathrm{hlm}\end{array}$

\section{Cap Kertas}

\section{Keterangan}

Naskah wawacan murtasyih ini dicatat dengan kodeTs-8/BLAJ/2012. Pemilik naskah ini adalah Atiqoh yang beralamat di Kampung Gelereng, Desa. Gelereng, Kecamatan Ciwandan, Kota Cilegon. 


\section{Koleksi Julita, Kampung Sumur Lubang, Desa Salira, Kecamatan Pulo Ampel}

\section{Wawacan Syeikh Abdul Qadir Jaelani}

$\begin{array}{cccc}\text { Ts-9/BLAJ/2012 } & \text { Aks } / \text { bhs } & \text { Prosa } & \text { HIm } \\ \text { Kertas HVS } & 24 \times 18 \mathrm{~cm} & 22 \times 16 \mathrm{~cm} & 13 \text { baris } / \mathrm{hlm}\end{array}$

\section{Cap Kertas}

\section{Keterangan}

Naskah Wawacan Syeikh Abdul Qadir Jaelani ini dicatat dengan kode Ts-9/BLAJ/2012. Pemilik naskah ini adalah Ustadz Julita yang beralamat di Kampung Sumur Lubang, Desa Salira, Kecamatan Pulo Ampel. 


\section{Koleksi Hikmat, Kampung/Desa Kresek, Kecamatan Kresek, Kabupaten Tangerang}

\section{Wawacan Syeikh Abdul Qadir Jaelani}

$\begin{array}{cccc}\text { Ts-10/BLAJ } / 2012 & \text { Aks } / \text { bhs } & \text { Prosa } & \text { HIm } \\ \text { Kertas Eropa } & 21 \times 16 \mathrm{~cm} & 18 \times 14 \mathrm{~cm} & 13 \text { baris } / \mathrm{hlm}\end{array}$

\section{Cap Kertas}

\section{Keterangan}

Naskah Wawacan Syeikh Abdul Qadir Jaelani ini dicatat dengan kode Ts-10/BLAJ/2012. Naskah ini adalah milik Ustadz Hikmat yang beralamat di Kampung/Desa Kresek, Kecamatan Kresek, Kabupaten Tangerang. 


\section{Koleksi KH. Tadjuddin, Kampung Cikeles, Desa Cipanas, Lebak Rangkasbitung}

\section{Amalan Tarekat Aceh}

BN-25/III_s/Ts-11/

BLAJ/2012

Kertas Polio
Aks Jawi/Bhs

Melayu

$20,5 \times 16 \mathrm{~cm}$
Prosa

$17,5 \times 14 \mathrm{~cm}$
$21 \mathrm{hlm}$

13 baris/hlm

\section{Cap Kertas}

\section{Keterangan}

Naskah Amalan Tarekat Aceh ini dicatat dengan kode lama BN25/III_s dan kode baru Ts-11/BLAJ/2012. Naskah ini disalin oleh Muhammad Sulaiman bin Kasad. Adapun pemilik naskah ini adalah $\mathrm{KH}$. Tadjuddin yang beralamat di Kampung Cikeles, Desa Cipanas, Lebak Rangkasbitung.

\section{Gambaran Isi}

Naskah ini berisi doa dan amalan pengikut tarekat dari Aceh (Syeikh Muhammad 'Ali Syihabuddin Aceh). Di dalamnya terdapat pula doa-doa agar badan kebal terhadap segala benda tajam baik besi, tombak, perak, dan lainnya. 


\section{Kitab Wawacan Syeikh Abdul Qadir Jaelani}

$\begin{array}{cccc}\text { BN-9/III_S/Ts-12/ } & \text { Aks Arab/Bhs } & \text { Prosa } & 97 \mathrm{hlm} \\ \text { BLAJ/2012 } & \text { Jawa Serang } & & \\ \text { Kertas Polio } & 21 \times 16,5 \mathrm{~cm} & 16,5 \times 14 \mathrm{~cm} & 13 \mathrm{baris} / \mathrm{h} / \mathrm{m}\end{array}$

\section{Cap Kertas}

\section{Keterangan}

Naskah Kitab Wawacan Syeikh Abdul Qadir Jaelani ini dicatat dengan kode lama BN-9/III_s dan kode baru Ts-12/BLAJ/2012. Pemilik naskah ini adalah $\mathrm{KH}$. Tadjuddin yang beralamat di Kampung Cikeles, Desa Cipanas, Lebak Rangkasbitung.

\section{Gambaran isi}

Naskah ini berisi wawacan Syeikh Abdul Qadir Jaelani yang ditulis dengan menggunakan bahasa Jawa Serang. Naskah ini diawali dengan doa yang ditujukan untuk Syeikh Abdul Qadir Jaelani kemudian menerangkan tujuan penulisan kitab ini. 
Kitab Wawacan Syeikh Abdul Qadir Jaelani

$\begin{array}{cccc}\text { BN-24/III_s/Ts-13/ } & \text { Aks Pegon/Bhs } & \text { Prosa } & 182 \mathrm{hlm} \\ \text { BLAJ/2012 } & \text { Jawa Serang } & \text { baris } / \mathrm{hlm} \\ \text { Kertas Eropa } & 21 \times 16,5 \mathrm{~cm} & 16 \times 12 \mathrm{~cm} & 11 \mathrm{~b}\end{array}$

\section{Cap Kertas}

Van Gelder

\section{Keterangan}

Naskah yang berjudul Kitab Wawacan Syeikh Abdul Qadir Jaelani ini dicatat dengan kode lama BN-24/III_s/ dan kode baru Ts-13/ BLAJ/2012. Naskah ini milik KH Tadjuddin yang beralamat di Desa Cipanas, Lebak, Rangkasbitung.

\section{Gambaran isi}

Naskah ini berisi bacaan (wawacan) tentang Syeikh Abdul Qadir Jaelani. 


\title{
Kitab Adzkiya'
}

\author{
BN-4_s/Ts-14/BLAJ/ \\ 2012 \\ Kertas Polio
}

Aks/Bhs Arab

Prosa

$24 \mathrm{hlm}$

$20,5 \times 16,5 \mathrm{~cm} \quad 18 \times 11 \mathrm{~cm} \quad 8$ baris $/ \mathrm{hlm}$

\section{Cap Kertas}

\section{Keterangan}

Naskah Kitab Adzkiya ini dicatat dengan kode lama BN-4_s dan kode baru Ts-14/BLAJ/2012. Naskah ini dikarang oleh Muhammad al-Zuhry al-Ghamrawiy. Pemilik naskah ini adalah $\mathrm{KH}$. Tadjuddin yang beralamat di Desa Sukasari, Kecamatan Cipanas, Lebak Rangkasbitung.

\section{Gambaran isi}

Naskah ini berisi tentang penjelasan kedudukan ilmu tarekat, syari'at, ilmu hakikat, dan ilmu ma'rifat. 


\section{Koleksi KH. Mas Sulaiman, Madrasah Al-Khaeriyyah Kecamatan Pontang, Kabupaten Serang}

\section{Masyahid al-Nasik}

$\begin{array}{cccc}\text { Ts-15/BLAJ/2012 } & \text { Aks/Bhs Arab } & \text { Prosa } & 133 \mathrm{hlm} \\ \text { Kertas Eropa } & 20,7 \times 27,7 \mathrm{~cm} & - & 7 \text { baris } / \mathrm{hlm}\end{array}$

\section{Cap Kertas}

Perisai dengan bunga tulip di tengah, mahkota di bagian atas Singa memegang pedang di tangan kiri

\section{Keterangan}

Naskah Masyahid an-Nasik ini dicatat dengan kodeTs-15/BLAJ/2012. Naskah ini dikarang oleh Syeikh Abdullah bin Abdul Qahhar AlBantani. Naskah ini merupakan peninggalan KH. Mas Sulaiman yang disimpan di Madrasah Al-Khaeriyyah yang beralamat di Kecamatan Pontang, Kabupaten Serang.

\section{Gambaran Isi}

Naskah ini berisi uraian tentang maqamat dalam dunia tasawuf. 


\section{Koleksi H. Madnadir, Kalapiyan, Serang}

\section{Qurrah al-'Ayn}

Ts-16/BLAJ/2012

Kertas Eropa
Aks/Bhs Arab

Prosa

$33 \times 21 \mathrm{~cm}$

$23 \times 12 \mathrm{~cm}$

$440 \mathrm{hlm}$

17 baris/hlm

\section{Cap Kertas}

\section{Keterangan}

Naskah Qurrah Al-'ayn ini dicatat dengan kode Ts-16/BLAJ/2012. Pemilik naskah ini adalah bapak $\mathrm{H}$. Madnadir yang beralamat di wilayah Kalapiyan, Serang. Kondisi naskah secara fisik masih baik dan masih terbaca.

\section{Gambaran Isi}

Teks ini berisi pengetahuan dasar-dasar mengenai ibadah dan tasawuf. 
Bab 6: Koleksi \& Katalogisasi: Naskah Tasawuf di Propinsi Banten 


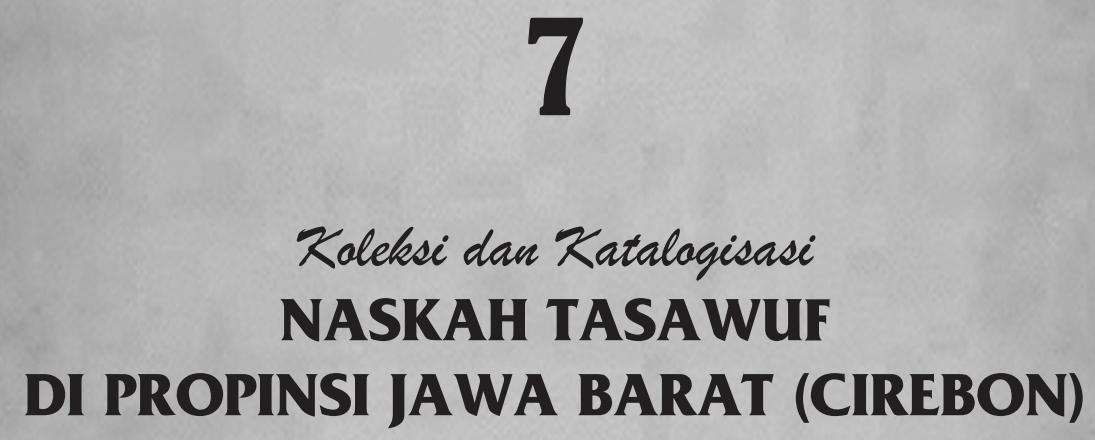

Oleh:

Harapandi Dahri

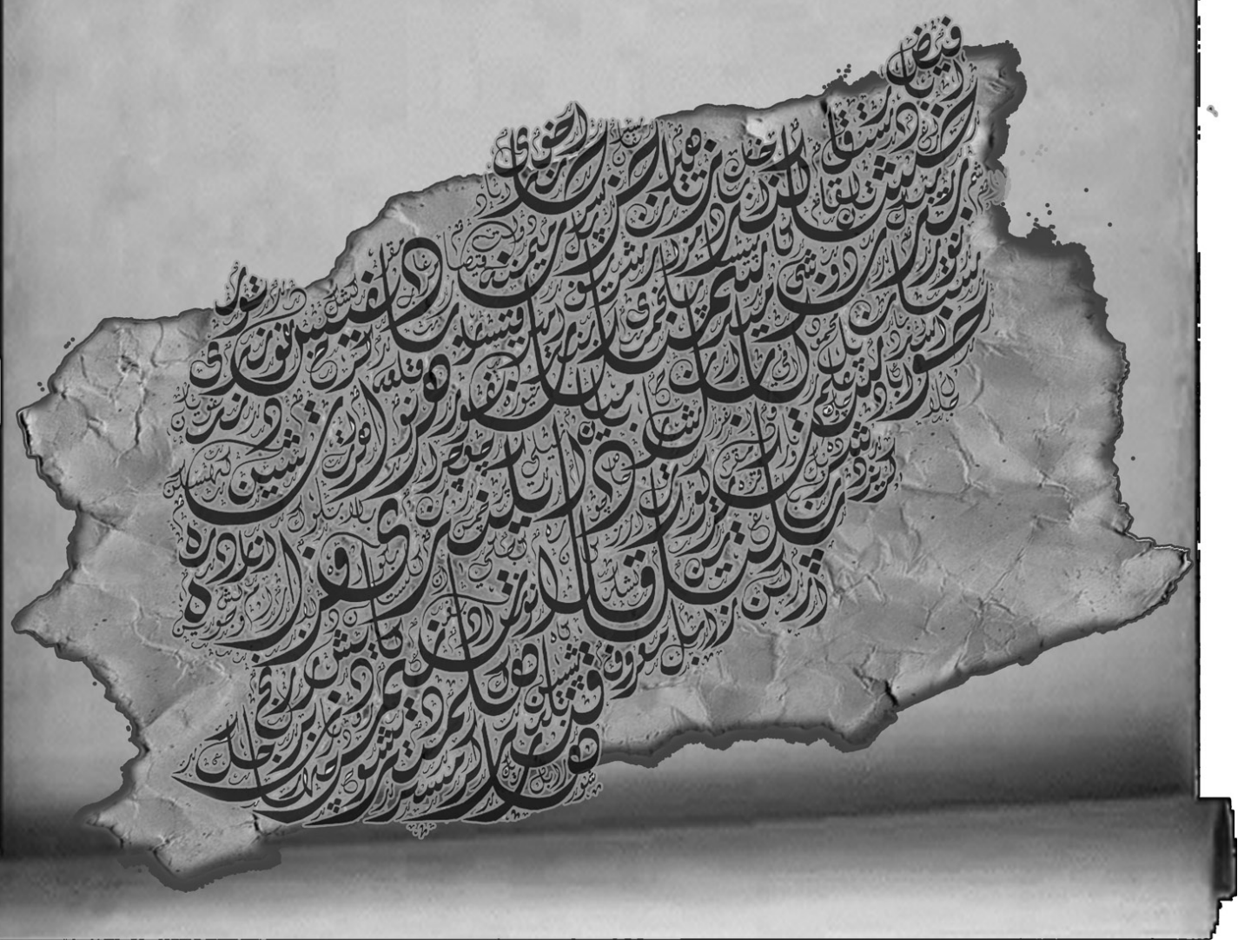




\title{
Koleksi drh. R.H. Bambang Irianto, BA
}

\author{
Naskah Jungjang \\ 01/AWN-01/Tw-1/TA/2012 \\ Arab \\ Prosa \\ $236 \mathrm{hlm}$ \\ Kertas Eropa \\ $20 \times 16,5 \mathrm{~cm} \quad 14,5 \times 9,5 \mathrm{~cm} \quad 17$ baris $/ \mathrm{hlm}$
}

\section{Pengarang}

Naskah ini memuat beberapa judul kitab yaitu: 1. HIm 10 s/d 24 berjudul Futuhatu al-Ilahiyah ditulis oleh Abu Zakaria Al-Anshori, bidang Tasawuf. 2. HIm 26 s/d 80 berjudul Majma' al-Bahrain ditulis oleh Abd al-Qudus Al-Hanafi Al-Husain, bidang Tasawuf. 3. Hal 82 s/d 100 berjudul Kasyfu al-Dhulmah fi Bayani Furuqi Hadzihi alUmmah ditulis oleh Tajuddin Abu Zakaria Al-Naqsabandi Al-Usmani Al-Abasi, bidang Tarikh. 4. HIm 102 s/d 122 berjudul Fathur Rohman Syarah Risalah Wali Ruslan ditulis oleh Abu Zakaria Al-Anshari, bidang Tasawuf. 5. HIm 124 s/d 211 berjudul Al-Hidayah li al-Insan ila al-Karim al-Mannan Syarah al-Hikam ditulis oleh Ali Al-Bayumi Al-Syafi'i, bidang Tasawuf. HIm 218 s/d 228 berjudul Ghayatu alIkhtishar Syarah al-Taqrib ditulis oleh Abu Abdullah Muhammad ibnu Qasim al-Syafi'i, bidang fiqih.

\section{Penulisan/Penyalinan}

- Futuhatul Ilahiyah selesai ditulis pada waktu Dhuha (Pagi), bulan Ramadhan, tahun Alif.

- Majma'ul Bahrain tidak diperoleh keterangan untuk penulisan kitab ini.

- Kasyfud Dhulmah fi Bayani Furuqi Hadzihil Ummah selesai ditulis pada waktu Dhuhur, bulan Rajab, tahun Alif.

- Fathurrahman Syarah Risalah Wali Ruslan selesai ditulis pada waktu Dhuhur, hari Kamis, tanggal 3, bulan Ruwah, tanpa tahun, Karang Sana, Kendal. 
- Al-Hidayah lil Insan Ilal Karimil Mannan Syarah Hikam selesai ditulis pada waktu 'Isya, hari Rabu, bulan Ramadhan, balad (Kota) Kendal.

- Ghayatul Ikhtishar Syarah Taqrib, tidak ada keterangan penulisan/ penyalinan.

\section{Kolofan}

- Futuhatul Ilahiyah, kolofon, wa qad farogo min naskhi ha hadza al-kitab waqt al-dhuha yaum a(l)-jum'ah syahr Ramadhan sanah alif, wa shalla a(llah) 'ala khair khalqihi Muhammad wa sallam, amin, tamm.

- Majma'ul Bahrain, tidak ada kolofon untuk Majma'ul Bahrain.

- Kasyfud Dhulmah fi Bayani Furuqi Hadzihil Ummah, kolofon, tammat waqta dhuhr syahr rajab sanah alif, tamm.

- Fathurrahman Syarah Risalah Wali Ruslan, kolofon, tamm alsyarhu bi-hamdi allah wa-'aunihi, wa-shalla allah 'ala-saydina muhammadin wa-alihi wa-shahbihi wasallama, amin daimani fial-dunya wa-al-akhirah, aghfiru allah fi-al-shawab wa-al-khata' muhammad rafi'i, tammat fi-al-naskhi al-kitab fathi al-rahman yaumi al-khamsi waqta dhuhrin fi syahri aruwah al-hilal tsalats wa-hadza al-kitabu fi baladi kendal fi al-dariy karang sana wa allah a'lam, shahibu al-kitab muhammad rafi'i faqir haqi.

- Ghayatul Ikhtishar Syarah Taqrib, tidak ada kolofon untuk ini.

\section{Cap Kertas}

Singa Mahkota (Concordia).

\section{Gambaran Isi}

Abu Zakaria al-Anshari di dalam Futuhatul Ilahiyah ini menjelaskan tentang garis-garis besar praktek tasawuf, tarekat, dan landasanlandasannya yang dirangkum dalam sepuluh pasal:

1. Definisi tasawuf dan pokok pembahasannya;

2. Rukun-rukun tasawuf dan tarek kepada Allah SWT;

3. Penjelasan tentang tauhid, iman, dan Islam; 
4. Penjelaan tentang ilmu laduni, ilmu yakin, meliputi; kakikat, hak, dan asal usulnya;

5. Penjelasan tentang ilham, wahyu, dan firasat;

6. Penjelasan tentang muhadlarah, mukasyafah, musyahadah, dan mu'ayyanah;

7. Penjelasan tentang syari'at, tarekat, dan hakikat;

8. Penjelasan tentang sebab-sebab sa'adah (kebahagiaan) dan syaqawah (kecelakaan);

9. Perasaan hati;

10.Penjelasan tentang pengambilan sumpah, memakai pakaian sufi, dan talqin zikir.

Di dalam pasal 1, Abu Zakaria al-Anshari menjelaskan tentang rukun-rukun tasawuf dan tarekat yang terdiri dari sepuluh rukun. Salah satu dari sepuluh rukun tasawuf dan tarekat itu adalah pemurnian tauhid kepada Allah Ta'ala dengan sebenar-benarnya. Pada pasal yang ke 10, Abu Zakaria al-Anshari menjelaskan tentang tata cara pengambilan sumpah yang harus dilaksanakan dalam keadaan suci, baik Syeikh (mursyid) maupun murid.

Majma'ul Bahrain yang ditulis oleh Abdul Qudus al-Hanafi alHusain memberikan pemurnian tauhid yang mengarah pada hakikat segala ada. Tiada wujud selain Dia. Makhluk semua adalah dinding, dan kamu adalah dinding; Allah Yang Maha Nyata tidak terhalang darimu, Dia terhalang darimu olehmu sendiri, dan kamu terhalang dengan dirimu sendiri, dan kamu terhalang darimu dengan-Nya, maka pisahkanlah dirimu darimu, maka kamu akan menyaksikan-Nya. Maknanya: Sesungguhnya makhluk itu hijab dari Allah SWT dari melihat mereka dan berhenti beserta mereka. Berhenti pada mereka menjadi hijab dari Allah SWT dan melihat sesuatu bagi dirinya berada juga sebagi hijab dari Allah SWT. Inilah makna ungkapan Syeikh: "Allah Yang Maha Nyata tidak terhalang darimu", karena Allah SWT jalla wa azza telah menciptakan makhluk sebagai hijab. Siapa yang berhenti pada makhluk, niscaya dia terhijab. Siapa yang telah Allah SWT kasyafkan (bukakan) bagi dirinya dari hijab (tirai/dinding) makhluk, dia melihat mereka dari 
jejak-jejak kuasa dan kehendak ilahi, maka tidak menjadi hijab makhluk dari Allah SWT, bahkan berjalan alat cermin yang dia dapat melihatnya dengan cahaya Allah SWT, yaitu cahaya ilmu laduni, sesunguhnya mereka menampakan kuasa dan kehendak. Makna ungkapan Syeikh: "dan kamu terhalang dengan dirimu sendiri", ketika kamu melihat hakikat wujudmu, maka kamu terhalang dengan-Nya. Ketika kamu terpisah dari dirimu, yaitu kamu fana dengan dirimu dengan sekiranya kamu tidak melihat wujud bagimu beserta wujud-Nya, bahkan kamu melihat wujudmu adalah dari wujud-Nya, niscaya kamu menyaksikan-Nya dengan diri-Nya, bukan dengan dirimu. Ketika ini, kamu menjadi Petauhid Sejati yang benar.

Kamu tidak perlu takut ketika kembali terbukanya penutup saat pandangan terjadi benturan keras. Berbeda dengan orang yang berhenti beserta makhluk, dia melihat keburukan dan kemanfaatan dari mereka, maka ditakutkan baginya ketika itu terjadi, aku mohon perlindungan kepada Allah SWT dari menyimpang dari kebenaran. Karena semua makhluk itu hijab dari Allah SWT, ketika hijab telah diangkat niscaya Allah SWT nyata. Hal itu ketika berada diujung kerusakan dan kehancuran saat mata terbelalak, ini adalah umumnya orang mukmin, karena mereka terhalang dengan makhluk dari Allah SWT. Saat hijab terbuka bagi mereka dengan Allah SWT, menjadi berubah apa yang ada pada mereka dari itikad mereka dan berbalik dalam pandangan mereka, maka ditakutkan atas mereka menyimpang dari kebenaran, kecuali orang yang telah Allah SWT tetapkan hatinya.

Kasyfud Dhulmah fi Bayani Furuqi Hadzihil Ummah yang ditulis oleh Tajuddin Abu Zakaria al-Naqsyabandi al-Usmani al-Abasi memberikan gambaran paham-paham firqah (sekte) dalam Islam. Untuk maslah firqah dalam tasawuf, Tajuddin Abu Zakaria alNaqsyabandi al-Usmani al-Abasi menulis: Adapun paham tasawuf itu terpecah menjadi sepuluh kelompok yang masih berdiri pada jalur kebenaran, yang sepenuhnya menghadap Allah Ta'ala dan berpaling dari lain-Nya, mereka beritikad sebagaimana itikad Ahli 
Sunnah wa al-Jama'ah. Firqah-firqah tasawufyang sepuluh ini adalah al-muhasibiyah, al-qashariyah, al-thafuriyah, junaidiyah, tsauriyah, al-salhalnah (sahaliyah?), al-hikamiyah, al-raziyah, al-hafifiyah, dan al-sayariyah. Adapun firqah tasawuf yang dianggap tidak benar menurut Tajuddin Abu Zakaria al-Naqsyabandi al-Usmani al-Abasi ada dua, yang pertama adalah al-hululiyah yang menganggap Allah Ta'ala itu maujud pada setiap tempat, berbicara dengan segala bahasa, dan tampak pada setiap manusia. Firqah yang kedua adalah al-ibahiyah, kelompok tasawuf ini membolehkan (menghalalkan) segala sesuatu dan meninggalkan ibadah pada suatu waktu. Mereka berkata: "sebagaimana ibadah tidak bermanfaat, dosa tidak berbahaya beserta tauhid dan makrifat".

Fathurrahman Syarah Risalah Wali Ruslan yang ditulis oleh Abu Zakaria al-Anshari secara umum sama dengan Majma'ul Bahrain yang ditulis oleh Abdul Qudus al-Hanafi al-Husain. Bahkan Abu Zakaria al-Anshari dalam Fathurrahman lebih sistematis dan teoritis dalam ulasan pembahasannya. Beliau memberi penjelasan tentang pembagian manusia: Makhluk (manusia) itu terbagi tiga kategaori; lemah, sehat, dan kuat. Kaum awam (umum), yaitu para mukmin, Kaum khawas (khusus), yaitu para wali, dan khawasul khawas (sangat khusus), yaitu para nabi, bagi mereka shalawat dan salam Allah Ta'ala. Syeikh Ruslan meruntutkanya dengan ungkapannya: Syari'at, dalam naskah yang lain: Maka syari'at itu untukmu wahai para lemah hingga kamu mencari-Nya Ta'ala dari-Nya untukmu dengan cara kamu mencari-Nya dengan ikhlas dan sungguhsungguh. Jika tidak, maka syari'at itu atasmu bukan untukmu. Hakikat itu bagi-Nya Ta'ala hingga kamu mencari-Nya ta'ala dengan-Nya untuk-Nya azza wajalla, bukan denganmu untuk-Nya dan bukan dengan-Nya untukmu. Sehingga tak terwaktu, dalam naskah yang lain: tak terbatas, dan bukan dimana (tak bertempat). Maka syari'at karena adanya itu perintah dengan amal-amal yang baku baginya itu punya batasan, sebagaimana shalat dua rakaat atau tiga, dan arah, seperti adanya shalat itu fardlu, sunah, terwaktu, atau tanpa waktu. Hakikat itu tak terbatas dan tidak ada 
arah baginya, karena hakikat itu 'tirai maknawi' dan karena yang mendirikannya adalah orang yang mengerti Allah (al-'arif billahi) yang telah melewati batas-batas (bagian-bagian) kemanusiaan. Karena dia berada dalam maqam jama (maqam bersama Allah), dan dia selamanya mencari Allah dengan Allah untuk Allah. Maka yang dicariya tak terbatas karenanya (tak terbatas itu adalah) hak Maha Disembah dan yang dicari oleh 'pendiri syari'at' (para kaum syari'at/orang yang menjalankan syari'at) itu terbatas (pahala dan surga).

Ghayatu al-lkhtishar Syarah al-Taqrib yang ditulis oleh Abu Abdullah Muhammad ibnu Qasim al-Syafi'i ini tidak selesai, sehingga pembahasannya baru sampai pada kitab thaharah (bersuci). Pun di dalam dalam kitab thaharah ini baru sampai pada sunah-sunah wudhu.

\section{Keterangan}

Sampul depan Naskah Jungjang 1 ini berwarna coklat terbuat dari kulit/karton tebal. Sampul sudah rusak dan dikait dengan lakban putih. Naskah dan sampul sudah lepas dari penjilidan. Pada halaman depan naskah ini terdapat tulisan dengan menggunakan bolpoin yang masih agak baru. Bunyi tulisan itu adalah li afqri alwara wa-adzli man fi al-qura haji hakam al-din bin haji mawardi jungjang arjawinangun cirebon (Kitab ini milik manusia terfakir dan terhina dalam kotanya, Haji Hakam al-Din bin Haji Mawardi Jungjang Arjawinangun Cirebon). Kalimat tulisan ini memberikan informasi, bahwa sebelumnya naskah ini milik Haji Hakamuddin bin Haji Mawardi yang berda di Desa Jungjang Arjawinangun Cirebon, Jawa Barat.

Beberapa halaman naskah bagian depan dan akhir sudah terlepas dari kurasannya. Tulisan cukup jelas terbaca. Tulisan berwarna hitam dan merah untuk matan, pasal, bab, dan rubrik baru. 


\section{Tauhid Isra' Mi'raj Tasawuf}

02/04-TH-1/Tw-1/PNC/2012

Arab

Prosa

$232 \mathrm{hlm}$

Kertas Eropa

$19,5 \times 33,5 \mathrm{~cm}$

$13 \times 21,5 \mathrm{~cm}$

8-17 baris/hlm

\section{Pengarang}

Kitab Jami'u al-Arkan tidak diperoleh nama penyusunnya. Ahmad Marzuki bin alm. Sajid Syarif untuk kitab 'Akidah al-'Awam, Itmam alDirayah syarah al-Niqayah tidak ada keterangan nama penulisnya. Fathu al-Rahman syarah Risalah Ruslan oleh Abu Zakaria al-Anshari. Risalah Insan Kamil oleh al-Syeikh Abd al-Karim bin Ibrahim. Risalah Akidah Ahl al-Sunah wa-al-Jama'ah tidak diperoleh nama penulisnya.

\section{Penulisan}

Mekah, Selasa, 5 Muharam 1192 H/3 Februari 1778 M.

\section{Kolofan}

1362 H Tahun Jim Awal

\section{Cap Kertas}

Singa dalam Medali Mahkota (Propatria), JVDeRL.

\section{Gambaran Isi}

Naskah ini memuat kurang lebih 7 teks kitab;

- Jami'ul Arkan tentang keimanan dan tasawuf,

- Aqidatul Awam tentang sifat Allah 20 ditulis oleh Ahmad Marzuki bin alm. Sajid Syarif,

- Syarah an-Niqayah tentang ushuludin dan tasawuf,

- Risalah Ruslaniyah ad-Dimasyqi dikomentari oleh Abu Yahya Zaariya al-Anshary dengan judul Fathurahman tentang tauhid,

- Risalah Syeikh Abdul Karim bin Ibrahim tentang insan kamil,

- Risalah Aqidah Ahlus Sunnah wal Jamaah.

- Khabar mi'raj. 


\section{Keterangan}

Warna tinta naskah ini menggunakan warna hitam dan merah; hitam untuk komentar atau penjelasan yang lazim digunakan oleh para penulis pada umumnya dan merah tinta merah digunakan untuk rubrikasi baru, pasal, matan, bab, dan kitab. Jenis tulisan atau khat yang digunakan mengarah kepada bentuk naskhi. Huruf atau aksara yang digunakan adalah aksara Arab untuk teks naskah dan aksara pegon untuk makna gandul atau arti yang ditulis di bawah teks dengan bahasa Jawa. Secara umum, kondisi fisik naskah dari segi fisik tulisan terbaca baik, kertas baik. Adapun penjilidan dijahit dengan benang, bersampul kulit sapi agak rusak di sudutnya. Asal naskah dari Desa Karangjati Singapura, nama desa ini sudah berganti menjadi Mertasinga Kecamatan Gunungjati, ditempat inilah situs Lawang Gede, reruntuhan keraton Singapura berada. Pemberian nama naskah itu dari kolektor. 


\section{Naskah Petarekan}

$\begin{array}{cccc}\text { 03/43-W-9/Tw-1/TA/2012 } & \text { Pegon } & \text { Prosa } & 20 \mathrm{hlm} \\ \text { Daluwang } & 14 \times 19 \mathrm{~cm} & 11 \times 15 \mathrm{~cm} & 12-13 \mathrm{baris} / \mathrm{hlm}\end{array}$

\section{Pengarang}

\section{Penulisan}

\section{Kolofan}

\section{Cap Kertas}

\section{Gambaran Isi}

Naskah yang lebih tepat dinamai Naskah Ajaran Syatariyah ini menjelaskan tentang lapisan-lapisan hati yang berjumlah tujuh lapis, dan lapisan hati ini sebenarnya merupakan pembagian model atau tipikal hati yang mengarah pada kriteria seseorang yang memilikinya. Dalam naskah ini juga dijelaskan tentang macammacam zikir dan tatacara zikir. Selanjutnya, pembahasan tentang hakikat rasa menjadi materi yang sangat menarik dalam naskah ini.

\section{Keterangan}

Naskah Petarekan dengan media kertas Daluwang ini tidak bersampul sama sekali. Sekalipun secara fisik kondisinya masih cukup baik dan terawat, namun sangat disayangkan naskah ini tidak utuh. Menurut penuturan Drh. HR. Bambang Irianto, BA, naskah ini diperoleh dari warisan secara turun temurun. Beliau menyebutkan bahwa naskah-naskah petarekan rata-rata tidak memiliki nama penulis atau tahun penulisannya. Hal ini dikarenakan naskahnaskah petarekan pada mulanya dipergunakan untuk kalangan sendiri atau untuk pegangan pribadi. 


\section{Tarekat Ratu Raja Fatimah Sami Kanoman}

$\begin{array}{cccc}\text { 04/H-19Na/Tw-1/TA/2012 } & \text { Pegon } & \text { Prosa } & 86 \mathrm{hlm} \\ \text { Kertas Eropa } & 21 \times 16,5 \mathrm{~cm} & 16 \times 11 \mathrm{~cm} & 11-12 \mathrm{baris} / \mathrm{hlm}\end{array}$

\section{Pengarang}

\section{Penulisan}

\section{Kolofan}

\section{Cap Kertas}

Lingkaran Mahkota/Propatria/J-Honing

\section{Gambaran Isi}

Silsiah Tarekat Syatariyah mendapatkan perhatian yang cukup baik dalam naskah ini. Silsilah sebagai legalitas tarekat merupakan keniscayaan dalam pergerakan tarekat yang berkembang di seluruh dunia Islam. Dengan adanya silsilah ini penganut tarekat mendapatkan kepastian jalur ilmu dan amal. Di samping itu, juga, dengan silsilah ini menjadi terungkap keterkaitan Tarekat Syatariyah Ratu Raja Fatimah Kanoman dengan Aceh, Banten, Pamijahan-Tasikmalaya, dan daerah lain.

Selanjutnya, pembahasan tentang metode zikir Syatariyah dijelaskan dengan gambar orang (ilustrasi) yang melingkupi dada, punggung, puser, dan hati yang menjadi objek perjalanan zikir Syatariyah. Di sampingnya penjelasan tentang martabat tujuh digambarkan (diilustrasikan) dengan lingkaran-lingkaran sebanyak tujuh lingkaran yang diberi keterangan tingkatan martabat tujuh, mulai dari alam ahadiyah hingga alam insan kamil.

\section{Keterangan}

Secara keseluruhan kondisi naskah ini masih cukup baik, walaupun ada sobekan dipinggir tidak mengganggu isi teks naskah. Dari 
penuturan pemilik, Drh. HR. Bambang Irianto, BA, dan dari judul yang ada, naskah ini berasal dari Keraton Kanoman Cirebon, salah satu Keraton di Cirebon yang melahirkan Pengguron Kaprabonan, sebuah lembaga pendidikan tinggi ilmu Islam dan ketatanegaraan yang ada di Cirebon pada masa itu. 


\section{Naskah Jawa Martabat Pitu}

$\begin{array}{cccc}\text { 05/38-X-3/Tw-1/TA/2012 } & \text { Jawa } & \text { Puisi } & 28 \mathrm{hlm} \\ \text { HVS } & 27 \times 21,5 \mathrm{~cm} & 24 \times 16,5 \mathrm{~cm} & 15 \mathrm{baris} / \mathrm{h} / \mathrm{m}\end{array}$

\section{Pengarang}

\section{Penulisan}

\section{Kolofan}

\section{Cap Kertas}

\section{Gambaran Isi}

Bagian awal naskah ini memberikan penjelasan tentang ilmu hakikat yang diibaratkan dengan wujil (biji). Penggambaran ilmu hakikat yang dilambangkan dengan wijil (biji) menjadi mudah untuk dipahami oleh masyarakat. Di dalam biji, pada saat masih menjadi biji, kita tidak dapat melihat daun, tangkal, bunga, apalagi buah. Seiring waktu berjalan, ketika biji itu mengeluarkan tunas dan hingga menjadi pohon dan berbuah dengan buah yang manis, kita baru menyadari bahwa hakikatnya buah telah 'ada' di dalam biji.

Selanjutnya, naskah ini membicarakan tentang martabat tujuh, seperti alam wahdah, alam ahadiyah, alam wahidiyah, alam mitsal, alam ruh, alam ajsam, dan alam insan kamil. Selanjutnya, naskah ini membicarakan tentang tajalli (penampakan Allah melalui makhlukNya) yang empat.

\section{Keterangan}

Dari kertasnya, naskah ini terbilang muda karena menggunakan kertas HVS. Naskah ini sudah tidak bersampul dan ada beberapa halaman yang lepas di bagian awal dan akhir. Hanya saja, kami tidak bisa menemukan halaman yang terlepas. Mungkin halaman yang lepas itulah nama penulis dan tahun penulisannya berada. 


\section{Tarekat Syatariyah Muhammadiyah}

$\begin{array}{cccc}\text { 06/28-W-7/Tw-1/TA/2012 } & \text { Pegon } & \text { Prosa } & 64 \mathrm{hlm} \\ \text { HVS bergaris } & 17 \times 10,5 \mathrm{~cm} & 7 \times 14 \mathrm{~cm} & 9 \mathrm{baris} / \mathrm{hlm}\end{array}$

\section{Pegarang \\ P. Potet Wijayaningrat}

\section{Penulisan}

\section{Kolofan}

\section{Cap Kertas}

\section{Gambaran Isi}

Dadalan (jalan) Tarekat Syatariyah dijelaskan pada permulaan naskah ini. Dadalan Tarekat Syatariyah ini lebih kepada amalanamalan (wirid-wirid) persiapan atau latihan sebelum orang (baca: murid) menjalankan Tarekat Syatariyah. Dadalan itu berupa istighfar, shalawat, dan doa-doa yang biasa digunakan oleh para penganut Tarekat Syatariyah. Selanjutnya, pembahasan tentang tata cara zikir Syatariyah yang dilambangkan dengan daerah zikir Syatari yang menyerupai badan manusia yang terdiri dari pundak, pusar, dan hati.

Pembahasan selanjutnya adalah tentang hakikat Muhammadiyah. Pembahasan ini dimulai dengan nurullah (cahaya Allah) yang disebut sebagai hakikat dari badan Nabi Muhammad SAW yang kemudian penganut dari ajaran ini dengan zikirnya yang khas dinamai Muhammadiyah.

\section{Keterangan}

Kondisi naskah ini masih cukup baik, tulisan cukup jelas terbaca. Jumlah kurasan naskah ini terdiri dari 2 (dua) kuras yang masing- 
masing kuras berisi 16 (enam belas). Dengan 64 (enam puluh empat) halaman, naskah ini memuat dua suatu yang teramat penting yaitu Tarekat Syatariyah dan Tarekat Muhammadiyah. 


\section{Petarekatan Muhammadiyah II Kacirebonan}

$\begin{array}{cccc}\text { 07/27-W-6/Tw-1/TA/2012 } & \text { Pegon } & \text { Prosa } & 54 \mathrm{hlm} \\ \text { Kertas Eropa } & 36 \times 22 \mathrm{~cm} & 25 \times 16,5 \mathrm{~cm} & 9 \mathrm{baris} / \mathrm{hlm}\end{array}$

\section{Pengarang}

Pangeran Potet Wijayaningrat

\section{Penulisan}

\section{Kolofan}

\section{Cap Kertas}

Propatria

\section{Gambaran Isi}

Naskah ini, secara keseluruhan, memuat ajaran-ajaran Tarekat Muhammadiyah yang menjadi pokok pergerakan tarekat di Cirebon. Karena kedalaman tarekat Muhammadiyah ini, kalangan Keraton Cirebon menganggap Tarekat Muhammadiyah adalah lanjutan atau tingkatan lanjut dari Tarekat Syatariyah. Hal itu mungkin didasarkan salah satunya pada martabat tujuh yang juga masih dijelaskan dalam hampir setiap naskah-naskah Tarekat Muhammadiyah.

\section{Keterangan}

Kondisi naskah ini sudah rusak parah, seluruh kurasan sudah terlepas dari jahitannya, sehingga naskah sudah berbentuk lembaranlembaran yang sudah tidak menyatu. Warna tinta menggunakan warna hitam, dan warna merah untuk rubrikasi baru atau pasal baru. Dalam naskah ini, praktek zikir digambarkan/diilustrasikan dengan lapaz Allah dan Muhammad yang membentuk manusia, satu gambaran persatuan yang mesra antara Allah SWT dan Muhammad SAW dalam penyelamatan manusia. 


\section{Petarekatan Muhammadiyah dan Martabat Pitu}

$\begin{array}{cccc}\text { 08/26-W-5/Tw-1/TA/2012 } & \text { Pegon } & \text { Prosa } & 68 \mathrm{hlm} \\ \text { Kertas Eropa } & 35 \times 22,5 \mathrm{~cm} & 25 \times 17 \mathrm{~cm} & 9-11 \mathrm{baris} / \mathrm{hlm}\end{array}$

\section{Pengarang}

Pangeran Potet Wijayaningrat

\section{Penulisan}

\section{Kolofan}

\section{Cap Kertas}

VDL - Singa dalam Lingkaran Mahkota

\section{Gambaran Isi}

Sifat Jamal (Maha Indah), Jalal (Maha Agung) dan Kamal (Maha Sempurna) yang dimiliki oleh Allah SWT menjadi pembahasan yang pokok dalam naskah ini. Keterkaitan sifat-sifat kesempurnaan Allah SWT tersebut menjadi latar belakang keyakinan dan pemahaman penganut Tarekat Muhammadiyah di Cirebon. Selanjutnya, naskah ini membahas tentang hakikat wujud manusia, Allah SWT, dan Muhammad SAW yang disebut hakikat muhammadiyah.

\section{Keterangan}

Kondisi naskah ini sudah rusak, seluruh kurasan sudah terlepas dari jahitannya, sehingga naskah sudah berbentuk lembaran-lembaran yang sudah tidak menyatu. Hanya tinggal satu kuras yang tersisa. Diperkirakan naskah ini berjumlah tiga kuras. Selanjutnya, lihat penjelasan naskah nomor 27 (W-6) dan 28 (W-7). 


\section{Kitab Syu'bah al-Iman}

$\begin{array}{cccc}\text { 09/05-W-1/Tw-1/TA/2012 } & \text { Pegon } & \text { Prosa } & 121 \mathrm{hlm} \\ \text { Kertas Eropa } & 25 \times 21 \mathrm{~cm} & 17,5 \times 12 \mathrm{~cm} & 9 \text { baris } / \mathrm{hlm}\end{array}$

\section{Pengarang}

Muhammad 'Arif (diduga/perkiraan)

\section{Penulisan}

Daerah Cigobang. Tidak ada informasi yang bisa menjelaskan tentang nama daerah Cigobang yang tertulis dalam naskah ini.

\section{Kolofan}

Iki Kitab Syu'bah al-Iman saking Muhammad 'Arif - Cigobang.

\section{Cap Kertas}

1812 - Tiga Tangkai Bunga Lili - Lingkaran Mahkota

\section{Gambaran Isi}

HIm. 1. berisi tentang doa Nabi Ibrahim yang berbunyi: inni wajjahtu wajhiya... dan seterusnya. Diteruskan dengan pembahasan mengenai bersuci, shalat, zakat, puasa, dan haji yang lazim dalam naskah-naskah fiqih. Kemudian, Pada hlm. 79-83 menjelaskan tentang hal-hal yang merusak amal ibadah seseorang seperti ujub, riya, sum'ah, namimah, hasud, gibah, dan hiyanah. Selanjutnya, pada halaman 92-99 menjelaskan tentang Martabat Tujuh yang terdiri dari ahadiyah, wahdah, wahidiyah, alam arwah, alam mitsal, alam ajsam, dan alam insan kamil. Hadis al-insanu sirri wa ana sirruhu (manusia itu rahasiaku dan aku rahasianya) juga dijelaskan dalam naskah ini. Pada pembahasan akhir dari naskah ini membicarakan tentang Hakikat Muhammadiyah yang lazim pada naskah-naskah Tarekat Muhammadiyah. 


\section{Keterangan}

Walaupun naskah ini sudah terlepas dari sampul dan jilidannya, secara keseluruhan, kondisi naskah ini cukup baik dan terawat. Tulisannya cuku jelas dengan menggunakan warna hitam dan merah untuk rubrikasi baru. Naskah ini cukup unik dan menarik dengan beberapa glossa yang dapat memberikan penjelasan isi teks kepada pembacanya. Glossa itu melingkar di sekeliling teks dari bagian atas, kiri, kanan, dan bawah teks asli. 


\section{Wahosan Bujang Genjong}

$\begin{array}{cccc}\text { 10/H12NA(16)/Tw-1/TA/2012 } & \text { Pegon } & \text { Puisi } & 36 \mathrm{hlm} \\ \text { Kertas Bergaris } & 21 \times 16 \mathrm{~cm} & 17 \times 14 \mathrm{~cm} & 10 \mathrm{baris} / \mathrm{hlm}\end{array}$

\section{Pengarang}

\section{Penulisan}

\section{Kolofan}

\section{Cap Kertas}

\section{Gambaran Isi}

Naskah model tembang (puisi) macapat ini menceritakan tentang dua sejoli yang sling jatuh cinta; si Pemuda bernama Bujang Genjong dan si Pemudi bernama Lara Gonjeng. Saat Bujang Genjong mengajukan lamaran kepada Lara Gonjeng, Lara Gonjeng menerimanya dengan satu syarat, yaitu Bujang Genjong harus tahu Ilmu Sejati.

Dengan rasa berat hati, Bujang Genjong berkelana mencari seorang guru yang dapat mengajari Ilmu tersebut, dan akhirnya Bujang Genjong bertemu dengan seorang guru yang bernama Bujang Lamong. Oleh Bujang Lamong, Bujang Genjong diajari tentang keatuan ilmu syari'at, tarekat, hakikat dan makrifat. Hal ini tersebut dalam tembang / pupuh ke 179 di bawah ini:

dedek ingkang den cireni

iku rupaneng syare'at

tarekat iku gabahe

hakikat rupaneng beras

menir iku ma'rifat

anane lili iku

menrang kalebungitungan 


\section{Keterangan}

Naskah ini merupakan naskah yang berisi pengajaran dengan model cerita dalam bentuk tembang. Menurut pemilik naskah, Drh. HR. Bambang Irianto, BA, bahasa naskah ini terkategori dalam bahasa Cirebon tengahan; di mana banyak bahasa-bahasa yang dapat dimengerti oleh umum sperti kalimat Bujang dan Rara. Di samping itu, naskah ini menggunakan bahasa Sunda untuk menyatukan dan memadukan dalam satu arti yang di sebut sebagai manunggal. 


\section{Koleksi Edwin Sujana}

\section{Bersih Ing Bersih}

17/EDS-04/Tw-1/TA/2012

Kertas Eropa
Pegon

Prosa

$44 \mathrm{hlm}$

$21 \times 15,8 \mathrm{~cm}$

$15 \times 10,5 \mathrm{~cm}$

9 baris $/ \mathrm{hlm}$

\section{Pengarang}

\section{Penulisan}

\section{Kolofan}

\section{Cap Kertas}

Propatria - Singa dalam Lingkaran Mahkota.

\section{Gambaran Isi}

Pada bagian awal naskah ini menjelaskan tentang petunjukpetunjuk rasa untuk menuju kesempurnaan hidup yang didambakan oleh orang-orang yang bersih. Pembahasan selanjutnya mengenai Sahadat Cerbon yang masyhur di antaranya Sahadat Panglepasan, Sahadat Sekarat, Sahadat Panarima, Sahadat Pangleburan, IImu Parantih, IImu Kasirnan, IImu Kasampurnan, dan Sahadat Sunya. Di samping itu, naskah ini juga menjelaskan tentang Sukma Jati (Hakikat Nyawa) yang dilanjutkan dengan pembahasan wudhu para Wali Sanga yang mencerminkan kesucian lahir dan batin. Setelah itu, naskah ini menjelaskan tentang Puji Ratu Adil dan Ratu Adil datang membawa pertanyaan yang harus dijawab oleh manusia secara umum. Selanjutnya naskah ini menjelaskan tentang ajaran Sunan Kalijaga yang terkait dengan kebersihan hati. 


\section{Keterangan}

Kondisi fisik naskah ini sudah rusak dan terlepas dari kurasannya. Naskah ini juga sudah tidak bersampul lagi. Warna tinta menggunakan warna hitam secara keseluruhan kecuali rubrikasi (awal pembahasan) baru menggunakan warna merah. Naskah ini warisan dari leluhur (orang tua) nya yang dahulu hidup di kalangan Keraton Kacirebonan. 


\section{Kaweruh Agama}

18/EDS-09/Tw-1/TA/2012

Kertas Eropa
Pegon

Prosa

$92 \mathrm{hlm}$

\section{Pengarang}

\section{Penulisan}

\section{Kolofan}

\section{Cap Kertas}

Agnani

\section{Gambaran Isi}

Naskah ini membahas tentang makna huruf hijaiyah dengan pemaknaan yang mengarah pada kebersihan hati dan sifat-sifat terpuji. Kemudian naskah ini juga memuat tentang ilmu dhahir dan ilmu yang lazim pada naskah-naskah keraton yang berjudul agama (Islam). Selanjutnya pembahasan martabat tujuh menjadi bagian yang tak terpisahkan dari naskah ini seperti pada naskahnaskah Cirebon yang menggunakan judul tarekat; baik Tarekat Syatariyah ataupun Tarekat Muhammadiyah. Bagian-bagian iman yang menjadi landasan keyakinan dan tolok ukur dalam prilaku dan makom ke-Islam-an seseorang (murid), juga dibahas dalam naskah ini. Pembahasan tentang hukum akli; wajib, wenang (jaiz), dan muhal yang biasa dibahas dalam ilmu kalam (tauhid) tak ketinggalan dijelaskan dalam naskah ini. Di bagian akhir, naskah ini membahas tentang bagian-bagian hati yang biasa di bahas dalam naskah-naskah Syatariyah. 


\section{Keterangan}

Kondisi naskah ini masih cukup baik dan tulisannya sangat jelas terbaca. Pembaruan penjilidan dengan kain yang berlapis dengan lem sebagai perekat menjadikan naskah ini tampak baru dan terawat. Tinta yang digunakan dalam naskah ini menggunakan warna hitam dengan warna merah sebagai rubrikasi baru. 


\section{Tarekat Syatariyah}
19/EDS-14/Tw-1/TA/2012
Pegon
Prosa
$48 \mathrm{hlm}$
Kertas Eropa
$21 \times 17,5 \mathrm{~cm}$
$17,3 \times 13,6 \mathrm{~cm}$
$10 \mathrm{baris} / \mathrm{hlm}$

\section{Pengarang}

\section{Penulisan}

\section{Kolofan}

\section{Cap Kertas}

\section{Gambaran Isi}

Dipermulaan, naskah ini menjelaskan makna kalimah tauhid (laa ilaaha illallah) yang bertingkat-tingkat sesuai dengan maqam seseorang dalam perjalanan tasawuf. Makna yang tertinggi dalam penjelasan ini adalah tiada yang wujud selain Allah (laa maujuda illallah). Selanjutnya, naskah ini membahas tentang ilmu wajib yang dilanjutkan dengan pembahasan mengenai sifat-sifat uluhiyah bagi Allah SWT. Penjelasan tentang zikir Syatariyah digambarkan dengan ilustrasi daerah zikir yang terdiri dari dua bahu, hati, dan puser yang menggunakan tulisan laa ilaaha illallah seperti yang ada pada naskah-naskah Tarekat Syatariyah yang lain. Selanjutnya, naskah ini membahas tentang iman, tauhid, dan makrifat yang secara harfiah berbeda makna, secara makna saling berdekatan, dan secara maksud bertingkatan.

\section{Keterangan}

Naskah ini sudah rusak dan tidak bersampul. Beberapa halaman ada sobek dan berlubang karena dimakan serangga. 


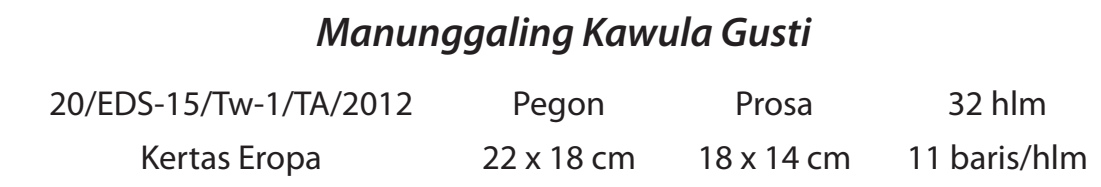

\section{Pengarang}

\section{Penulisan}

\section{Kolofan}

\section{Cap Kertas}

\section{Gambaran Isi}

Pembahasan naskah ini dimulai dengan penjelasan tentang martabat tujuh yang sering disebutkan dalam naskah-naskah Tarekat Syatariyah dan Muhammadiyah. Tentang ajaran Manunggaling Kawula Gusti yang dapat disajikan dari naskah ini adalah bahwa seseorang harus melebur dirinya jadi nyawa (ke dalam nyawa, ruh) sehingga menjadi rasa yang dapat merasakan kehadiran Allah SWT dalam kesadarannya, lalu sirna (fana) dengan Jatining Allah (Dzat Allah/Hakikat Allah) yang maujud tanpa harus menggunakan jasad. Lebur dalam hadirat ilahi Yang Maha Agung, lebur sehingga tak lagi menyadari keberadaan dirinya, yang ada hanya Allah; laa maujuda illallah. Untuk mencapai fana (sirna) yang dimaksud, di bagian akhir naskah ini menjelaskan tentang tata cara zikir yang dapat mengantarkan seseorang (salik) kepada ke-fanaan yang dikehendaki.

\section{Keterangan}

Naskah ini berasal dari Pangeran Yopi Kamil Dendabrata, masih kerabat Keraton Kacirebonan. Begitu juga naskah-naskah lain yang dimiliki oleh Edwin Sujana. Kondisi naskah ini sudah sangat memperihatinkan, berbagai kertas yang sudah sobek di sana-sini. Selain itu, tintanya sudah banyak yang tembus ke halaman lain. 


\section{Koleksi Elang Hilman}

\section{Petarekatan}

21/H-11/Tw-1/TA/2012

$\begin{array}{ccc}\text { Pegon } & \text { Prosa } & 58 \mathrm{hlm} \\ 28 \times 20,5 \mathrm{~cm} & 25 \times 17,5 \mathrm{~cm} & 10 \mathrm{baris} / \mathrm{hlm}\end{array}$

\section{Pengarang}

\section{Penulisan}

\section{Kolofon}

\section{Cap Kertas}

CR-Propatria-Perempuan dalam pagar menghadap ke kiri

\section{Gambaran Isi}

Naskah ini menjelaskan tentang metode zikir Tarekat Naqsyabandiyah dengan ilustrasi gambaran hati untuk membantu pemahaman para murid. Selanjutnya, naskah ini menjelaskan tentang Puji Sekarat yang mengarahkan seluruh yang ada kepada Allah SWT. Puji Sekarat dimaksudkan untuk mempersiapkan diri menghadapi kematian yang datang kepada manusia setiap saat. Lalu dilanjutkan dengan pembahasan tentang mati sebelum meninggal (mati dalam hidup) yang menjadi ciri khas dari ajaran tasawuf versi Jawa. Atau kebanyakan orang mengenalnya dengan ilmu kebatinan.

Pada bagian berikutnya, naskah ini membahas tentang daerah zikir Naqsyabandiyah atau Tarekat Naqsyabandiyah) dengan mengacau pada Risalah Syeikh Bahaul Haq Waddin dan dilanjutkan dengan pembahasan tentang cermin hati (cermin ruh) yang berujung pada pembersihan hati dan pikiran. Selanjutnya membahas tentang martabat tujuh yang sudah sering ditulis dalam naskah-naskah Tarekat Syatariyah dan Muhammadiyah. 


\section{Keterangan}

Naskah koleksi Elang Muhammad Hilman ini tergolong naskah yang sangat unik dan langka, karena naskah ini membahas tentang Tarekat Naqsyabandiyah. Naskah ini tergolong lengkap walaupun dibagian akhir ada beberapa halaman yang sobek. Aksara yang digunakan dalam naskah ini sebagian menggunakan aksara pegon dan sebagian yang lain menggunakan carakan. Adapun warna tinta naskah ini menggunakan warna hitam dengan merah untuk bagian-bagian penting, rubrik baru, atau pasal baru. 


\section{Petarekatan}

22/H-12/Tw-1/TA/2012

Kertas Eropa

$\begin{array}{ccc}\text { Pegon } & \text { Prosa } & 28 \mathrm{hlm} \\ 27 \times 19 \mathrm{~cm} & 24 \times 14 \mathrm{~cm} & 9 \text { baris } / \mathrm{hlm}\end{array}$

\section{Pengarang}

\section{Penulisan}

\section{Kolofon}

\section{Cap Kertas}

\section{Gambaran Isi}

Bagian awal naskah ini menguraikan tentang makna-makna dan pengertian Haq Allah SWT dan Makhluk (manusia) yang menjadi ciptaan-Nya. Selanjutnya, naskah ini menjelaskan tentang maknamakna hati, ruh, zat, ilmu, tajalli, cahaya, dan hal-hal lain yang menjadi pengajaran tasawuf. Penjelasan yang diberikan cukup singkat dan padat, sehingga naskah yang hanya berisi 28 halaman ini kaya dengan istilah-istilah tasawuf dengan penjelasan yang pendek dan menarik.

\section{Keterangan}

Bahasa yang digunakan naskah ini adalah bahasa Arab dengan makna gandul (kitab gondrong) yang sering terdapat di pesantren. Kondisi naskah ini agak rusak dan tidak bersampul. Adapun sampul baru yang digunakan berupa kertas bekas kantong semen. 


\section{Petarekatan}

$\begin{array}{cccc}\text { 23/H-13(07)/Tw-1/TA/2012 } & \text { Pegon } & \text { Prosa } & 22 \mathrm{hlm} \\ \text { Kertas Eropa } & 20,3 \times 15,5 \mathrm{~cm} & 16 \times 12,3 \mathrm{~cm} & 10 \mathrm{baris} / \mathrm{hlm}\end{array}$

\section{Pengarang}

\section{Penulisan}

\section{Kolofon}

\section{Cap Kertas}

CR - Propatria

\section{Gambaran Isi}

Seperti naskah-naskah petarekan lainya, naskah ini pun memuat pembahasan tentang martabat tujuh, yaitu alam wahdah, alam ahadiyah, alam wahidiyah, alam arwah, alam mitsal, alam ajsam, dan alam insan kamil. Pembahasan selanjutnya, berkisar tentang ruh yang diteruskan dengan pembahasan mengenai jism dan nafa. Salah satu hal yang menarik dalam naskah petarekan ini adalah kutipan dari Mansur al-Halaj yang kontroversial, yaitu ana al-haq.

\section{Keterangan}

Naskah ini sudah rusak dan tidak bersampul, sampul baru yang digunakan adalah kertas bekas bungkus semen yang tampak masih baru. Seperti dalam naskah-naskah petarekan yang lain, naskah ini pun menggunakan ilustrasi tujuh bulatan dalam menjelaskan tentang martabat tujuh. 


\section{Primbon Siti Ratna}

24/H-14/Tw-1/TA/2012

Kertas Eropa
Pegon

$21,3 \times 17,2 \mathrm{~cm}$
Prosa

$122 \mathrm{hlm}$

$17 \times 14 \mathrm{~cm} \quad 13 \mathrm{baris} / \mathrm{hlm}$

\section{Pengarang}

\section{Penulisan}

\section{Kolofon}

\section{Cap Kertas}

\section{Gambaran Isi}

Naskah Primbon yang oleh pemiliknya, Elang Muhammad Hilman, dinamai dengan Primbon Siti Ratna ini berisi tetang cerita suluk yang menjadi bagian dari tasawuf versi Jawa. Pembahasan selanjutnya adalah mengenai ngelmu sampurna (ilmu sempurna), sampurnaning syahadat (syahadat sempurna), uruip kang sejati (hakikat hidup), rasa tunggal (rasa satu/satu rasa dengan Allah), tunggal urip (satu hidup), dan hal-hal lain yang sejenis.

\section{Keterangan}

Kondisi naskah ini masih cukup baik dan utuh hanya sudah tidak bersampul. Bahasa naskah yang digunakan yaitu bahasa Cirebon. Warna tinta menggunakan warna hitam dan tidak ada catchword (kata alihan). Naskah ini juga tidak menggunakan iluminasi atau pun ilustrasi. 


\section{Primbon Siti Ratna II}

25/H-16/Tw-1/TA/2012

Kertas Eropa
Pegon

Prosa

$185 \mathrm{hlm}$

$20,5 \times 17 \mathrm{~cm} \quad 16 \times 13 \mathrm{~cm}$
11 baris/hlm

\section{Pengarang}

\section{Penulisan}

\section{Kolofon}

\section{Cap Kertas}

\section{Gambaran Isi}

Naskah ini memuat berbagai macam pembahasan yang terkait dengan ilmu-ilmu agama. Permulaan naskah ini menguraikan tentang ilmu tauhid; sifat-sifat Allah dan Rasul. Selanjutnya naskah ini memuat tentang Tarekat Syatariyah yang sering dibahas dalam naskah-naskah yang lain. Pembahasan tentang doa-doa, azimatazimat, shalat lailatul qadar, dan pengobatan di bahas kemudian setelah pembahasan tentang Tarekat Syatariyah.

\section{Keterangan}

Kondisi naskah ini masih baik dan utuh. Penjilidan menggunakan karton yang agak tebal. Menurut pemiliknya, Elang Muhammad Hilman, naskah ini berasal dari leluhurnya yang bernama Ratu Siti Ratna yang bersuamikan Pangeran Ibrahim dari Keraton Kacirebonan. Untuk itu, pemilik naskah ini cenderung menamai naskahnya dengan nama Primbon Siti Ratna. Aksara yang digunakan dalam primbon ini tergolong lengkap, mulai dari aksara Arab dengan bahasa Arabnya, dan aksara Pegon dan arakan dengan bahasa Cirebon atau Jawa. Warna tinta pada naskah ini menggunakan warna hitam dan merah untuk rubrikasi baru yang lazim dalam naskah-naskah Cirebon yang lain. 


\section{Suluk Lima}

26/H-17/Tw-1/TA/2012

Kertas Eropa
Pegon

$21 \times 16 \mathrm{~cm}$
Prosa

$136 \mathrm{hlm}$

$16 \times 11,5 \mathrm{~cm} \quad 11$ baris $/ \mathrm{hlm}$

\section{Pengarang}

\section{Penulisan}

\section{Kolofon}

\section{Cap Kertas}

Concordia - Singa dalam Lingkaran Mahkota

\section{Gambaran Isi}

Pembahasan naskah ini dimulai dengan penjelasan tentang makna kalimat thayibah, laa ilaaha illallah, kemudian disusul dengan pembahasan mengenai niat shalat bagi golongan ahli syariat, ahli tarekat, ahli hakikat, dan ahli makrifat. Selanjutnya, naskah ini membahas tentang Johar Awal yang disebut roh idhofi, nama lain dari Nur Muhammad yang menjadi cikal bakal seluruh alam semesta. Dilanjutkan dengan pembahasan tentang martabat tujuh yang lazim pada naskah-naskah Syatariyah.

Pembahasan selanjutnya berkisar tentang ilmu tauhid yang meliputi sifat-sifat Allah yang dua puluh. Kemudian dilanjutkan tentang makrifat dan rasa yang dibahas secara detail dan jelas.

\section{Keterangan}

Kondisi naskah ini masih baik, hanya ada beberpa halaman yang sobek karena terlipat terlalu lama. Penjilidan menggunakan kulit yang tebal berwarna coklat kehitaman. Warna tinta menggunakan warna hitam dan merah untuk ayat, hadis, dan teks yang menggunakan bahasa Arab. Adapun teks bahasa Cirebon atau Jawa 
ditulis dengan tinta hitam. Menurut Elang Muhammad Hilman, naskah ini berasal dari Elang Muhammad Arifuddin Adikusuma Bratawirja Muhammad Badruddin dari Pengguron Kaprabonan (Keraton Kaprabonan) yang terletak di Jalan Lemahwungkuk Kota Cirebon. 


\section{Kitab Agama}

27/H-18/Tw-1/TA/2012

Pegon

Prosa

$468 \mathrm{hlm}$

Kertas Eropa

$21,5 \times 17 \mathrm{~cm}$

$15,3 \times 12,5 \mathrm{~cm}$

9 baris/hlm

\section{Pengarang}

\section{Penulisan}

\section{Kolofon}

\section{Cap Kertas}

\section{Gambaran Isi}

Secara keseluruhan, naskah ini membicarakan tentang ilmu tasawuf dalam versi Jawa yang lengkap. Nama Raden Hangabehi Ronggowarsita disebutkan beberapa kali dalam naskah ini, di samping itu juga, beberapa catatanya disebutkan dengan jelas. Bagian awal naskah ini membicarakan tentang tata cara berguru yang mengarah pada cara-cara bai'at yang biasa dilakukan oleh penganut tarekat.

Selanjutnya, pembahasan mengarah kepada majenunillah (gila kepada Allah, sirna, fana) dengan menyebutkan acuan yang diambil dari Pangeran Arya Dipati Nagara. Selanjutnya, naskah ini menyebutkan tokoh-tokoh yang layak menjadi Guru (mursyid?) seperti Niti Sampurna, Kiyahi Citra Waspana, Kiyahi Wira Darma, Kiyahi Dadap Tulis, Kiyahi Yatna Sampurna, dan Mas Behi Kirya Guna. Pembahasan selanjutnya mengenai urutan dan tingkatan ilmu yang dimulai dengan ilmu syariat, ilmu tarekat, ilmu hakikat, dan terakhir ilmu makrifat. Melengkapi pembahasannya tentang ajaran budi pekerti dan ilmu makrifat, naskah ini menceritakan tentang Syeikh Maulana Maghribi yang sedang memberi wejangan di mimbar Masjid Demak. Syeikh Maulana Mahgribi pada saat itu 
sedang memberi pelajaran kepada Wali Sanga tentang sasmita, ahli fana, ahli makrifat, dan wejangan lainya yang masih terkait dengan ilmu kebatinan atau ilmu tasawuf.

\section{Keterangan}

Naskah ini sudah lepas dari covernya, bahkan ada beberapa lembar halaman yang sudah sobek dan lepas dari jahitan. Bahasa yang digunakan naskah ini adalah bahasa Cirebon atau Jawa. Di bagian bawah, terdapat teks alihan (catchword) yang menandai halaman berikutnya. Tintanya menggunakan warna hitam dan merah untuk menuliskan nama-nama tokoh yang disebutkan. 


\section{Tarekat Syatariyah}

28/H-19/Tw-1/TA/2012

Kertas Eropa
Pegon

Prosa

$24,5 \times 19,5 \mathrm{~cm} \quad 19 \times 17 \mathrm{~cm}$
$46 \mathrm{hlm}$

$11 \mathrm{baris} / \mathrm{hlm}$

\section{Pegarang}

\section{Penulisan}

\section{Kolofon}

\section{Cap Kertas}

LMG

\section{Gambaran Isi}

Pada bagian awal, naskah ini menjelaskan tentang makna Kalimat thayibah, laa ilaaha illallah, yang diurakan secara nafi itsbat. Sebagaimana naskah Syatariyah yang lain, naskah ini juga menjelaskan tentang martabat tujuh dan daerah zikir Syatariyah. Selanjutnya, naskah ini membahas tentang Tarekat Rifa'iyah dan diteruskan dengan gambaran daerah zikir Rifa'iyah. Lalu menggambarkan tentang hakikat penciptaan yang bersumber kepada Nur Muhammad. Bagian akhir naskah ini menjelaskan tentang sifat dua puluh yang lazim pada pelajarn ilmu tauhid.

\section{Keterangan}

Naskah ini sudah rusak dan lepas dari sampulnya. Bahasa naskah ini menggunakan bahasa Cirebon dengan warna tinta hitam dan merah untuk rubrikasi baru. Pembahasan zikir Syatariyah dan zikir Rifa'iyah dijelaskan dengan ilustarsi. Di samping itu, juga ada ilustarsi ulam jilu (tiga ikan satu kepala) untuk menjelaskan tentang penciptaan dan makrifat. 


\section{Ushul Suluk}

29/H-20/Tw-1/TA/2012

Pegon

Prosa

$60 \mathrm{hlm}$

Kertas Eropa

$21,5 \times 15,5 \mathrm{~cm}$

$16,3 \times 11 \mathrm{~cm}$

15 baris/hlm

\section{Pengarang}

\section{Penulisan}

\section{Kolofon}

\section{Cap Kertas}

GBA\&M - Anjing Bermahkota dalam Lingkaran Oval

\section{Gambaran Isi}

Naskah ini berisi puji-pujian dan shalawat yang di tulis dalam bentuk nadham/nasyid. Pemiliknya, Elang Muhammad Hilman, menjelaskan bahwa naskah ini berisi suluk rifa'iyah yang berlaku di kalangan penganut Tarekat Rifa'iyah, suatu zikir Tarekat Rifa'iyah yang disusun dalam bentuk tembang yang mengacu pada sastra Arab.

\section{Keterangan}

Naskah ini menggunakan bahasa dan aksara Arab. Kondisi naskah cukup baik dan tulisan sangat jelas terbaca. Di samping itu, naskah ini mempunyai iluminasi berupa gambar-gambar bunga dalam kotakyang di bentuk serperti pohon. Naskah ini tidakmenggunakan penomoran halaman dan teks alihan (catchword). 


\section{Tasawuf}

30/H-25/Tw-1/TA/2012

Kertas Eropa
Pegon
Prosa
$56 \mathrm{hlm}$
$17,5 \times 10,7 \mathrm{~cm} \quad 16 \times 10 \mathrm{~cm} \quad 11 \mathrm{baris} / \mathrm{hlm}$

\section{Pengarang}

\section{Penulisan}

\section{Kolofon}

\section{Cap Kertas}

\section{Gambaran Isi}

Naskah yang belum diberi judul oleh penulis dan atau pemiliknya ini membahas tentang bagian (proses) tajalli dengan pembahasan yang mendalam. Dalam bagian tajalli yang sempurna, naskah ini memberikan contoh dengan wujud Muhammad Rasulullah SAW. Selanjutnya, naskah ini menguraikan tentang macam-macam nyawa; nyawa malakiyah, nyawa insaniyah, nyawa hayawaniyah, dan nyawa syaithaniyah.

\section{Keterangan}

lluminasi naskah ini berupa garis-garis yang membentuk kotak kecil-kecil dan bentuk gubuk dengan warna merah dan biru. Kondisi naskah sudah agak rusak; sudah terlepas dari sampul dan ada beberapa halaman yang hilang. Di samping itu, naskah ini tidak menggunakan teks alihan (catchword) dan penomoran halaman. Warna tinta teks naskah seluruhnya berwarna hitam dengan menggunakan bahasa Cirebon. 


\section{Tasawuf}

31/H-29/Tw-1/TA/2012

Pegon

Prosa

$56 \mathrm{hlm}$

Kertas Eropa

$21 \times 16,5 \mathrm{~cm}$

$17,3 \times 14 \mathrm{~cm}$

8-12 baris/hlm

\section{Pengarang}

\section{Penulisan}

\section{Kolofon}

\section{Cap Kertas}

\section{Gambaran Isi}

Naskah ini menjelaskan tentang martabat tujuh yang sering diuraikan dalam naskah-naskah Tarekat Syatariyah dan Muhammadiyah. Selanjutnya, naskah ini membahas tentang sukma langgeng dan manunggaling kaula gusti. Pembahasan ini mungkin masih terkait dengan naskah lain serupa yang berbeda judul seperti naskah yang diberi judul kitab agama dengan nomor 27/H-18/Tw-1/TA/2012.

\section{Keterangan}

Kondisi naskah ini masih cukup baik hanya sudah lepas dari covernya. Naskah yang sebenarnya tidak berjudul ini, diberi nama oleh pemiliknya, Elang Muhammad Hilman, dengan nama martabat tujuh sesuai dengan isi kandungan teks yang ada. naskah ini tidak menggunakan penomoran halaman dan kata alihan (catchword). Warna tinta yang digunakan adalah warna hitam. 


\section{Tasawuf}

32/H-30/Tw-1/TA/2012

Kertas Eropa
Pegon

$17,8 \times 11 \mathrm{~cm}$
Prosa

$52 \mathrm{hlm}$

17 baris/hlm

\section{Pengarang}

\section{Penulisan}

\section{Kolofon}

\section{Cap Kertas}

\section{Gambaran Isi}

Naskah ini membicarakan tentang bab-bab yang ada tasawuf, mulai dari taubat, sabar, syukur, zikir, dan bab-bab lainya. Secara singkat, dapat dikatakan bahwa naskah ini memuat dua bab besar dalam tasawuf yaitu sifat mahmudah (sifat terpuji) dan sifat madzmumah (sifat tercela) dengan pembahasa yang tidak terlalu panjang.

\section{Keterangan}

Kondisi naskah ini sudah rusak dan sudah lepas dari sampulnya. Bahasa yang digunakan adalah bahasa Cirebon. Tidak ada iluminasi atau pun ilustrasi dalam naskah ini, beguitu juga kata alihan (catchword). Sekalipun kertas yang digunakan adalah Kertas Eropa, namun naskah ini tidak menggunakan watermark, countermark, dan clain lines. Satu-satunya ciri yang ada adalah penggunaan laid lines (garis tipis) khas produk Eropa. 


\section{Tasawuf}

33/H-32/Tw-1/TA/2012

Jawa

Prosa

$34 \mathrm{hlm}$

Kertas Bergaris

$20,5 \times 16 \mathrm{~cm}$

$18,5 \times 13,5 \mathrm{~cm}$

12 baris/hlm

\section{Pengarang}

\section{Penulisan}

\section{Kolofon}

\section{Cap Kertas}

\section{Gambaran Isi}

Permulaan pembahasan yang diberikan oleh naskah ini adalah ilmu tauhid mengenai sifat dua puluh yang wajib bagi Allah, dua puluh muhal bagi Allah, satu jaiz bagi Allah, empat wajib bagi rusul, empat muhal bagi rusul, dan satu jaiz bagi rusul. Pembahasan selanjutnya yang terkandung dalam naskah ini adalah tentang Martabat Tujuh; alam ahadiyah, alam wahdah, alam wahidiyah, alam arwah, alam mitsal, alam ajsam, dan alam insan kamil yang biasa dijelaskan dalam naskah-naskah tarekat Syatariyah dan Muhammadiyah.

\section{Keterangan}

Kondisi fisik naskah ini masih baik. Naskah ini diberi sampul baru menggunakan kertas bekas kalender. Naskah ini tidak menggunkan penomoran halaman dan kata alihan (catchword). Tetapi naskah ini menggunakan ilustrasi yang cukup unik dan khas. Ilustarsi yang dimaksud adalah gambar orang dan wayang yang berada dalam tujuh lingkaran yang menjadi gambaran atas martabat tujuh yang dijelaskan. Naskah-naskah lain yang menjelaskah martabat tujuh hanya menggambarkan ilustrasi tujuh bulatan yang terdiri dari warna hitam dan putih, bukan gambar, apalagi gambar wayang. 


\section{Tasawuf}

34/H-34/Tw-1/TA/2012

Kertas Eropa
Jawa

Prosa

$17,5 \times 11 \mathrm{~cm}$

$16 \times 9 \mathrm{~cm}$

$56 \mathrm{hlm}$

9 baris/hlm

\section{Pengarang}

\section{Penulisan}

\section{Kolofon}

\section{Cap Kertas}

\section{Gambaran Isi}

Hampir menyerupai primbon yang berisi tentang berbagai macam pembahasan, naskah ini juga membahas tentang berbagai hal yang ada dalam primbon. Hanya pada permulaannya, naskah ini mengetengahkan pembahasan tentang baitul ma'mur, baitullah, lauh makhfudh, qalam, dan kursiyang semuanya itu ada dalam tubuh kita. Jadi naskah ini memandang jasad kita memiliki segalanya yang ada alam gaib yang berhubungan dengan keimanan seseorang. Selanjutnya, naskah ini menjelaskan tentang makrifat dan hal-hal yang berhubungan dengan makrifat dan menjadi alat makrifat. Setelah itu, pembahasan dilanjutkan dengan doa-doa basmalah. Selain itu juga, naskah ini menjelaskan tentang perhitungan aksara Jawa untuk mengetahui keberuntungan dan na'as.

\section{Keterangan}

Secara umum, kondisi fisik naskah ini masih sangat baik, hanya ada beeberapa halaman yang lepas. Naskah ini tidak menggunkan penomoran halaman dan kata alihan (catchword). Akan tetapi, dalam naskah ini ada iluminasi gambar gubuk tinggi dengan empat tiang soko guru yang dijadikan tangga untuk naik ke 
dalamnya. Atap gubuk tinggi ini berwarna hijau. Dinding-dinding gubuk ini berwarna merah dengan campuran warna hijau. Sebuah iluminasi (mungkin juga ilustrasi untuk kondisi tingkatan hati mencapai makrifat) yang indah untuk sebuah naskah tasawuf yang menjelaskan tentang alam gaib (lauh makhfud, 'arsy, kursy, dan sejenisnya). 


\title{
Koleksi Elang Panji Jaya
}

\author{
Tasawuf dan Tauhid \\ 35/EPJ-02/Tw-1/TA/2012 \\ Pegon \\ Prosa \\ $188 \mathrm{hlm}$ \\ Kertas Eropa \\ $21 \times 17,3 \mathrm{~cm} \quad 16,5 \times 12,5 \mathrm{~cm} \quad 13$ baris $/ \mathrm{hlm}$
}

\section{Pengarang}

\section{Penulisan}

\section{Kolofon}

\section{Cap Kertas}

\section{Gambaran Isi}

Naskah ini membahas tentang tasawuf versi Jawa yang cukup paripurna dan lengkap. Pembahasan yang diberikan meliputi; rasa Yang Agung, rasa Yang Gaib, wujud purba, hakikat asma (nama), hakikat musamma (objek nama), pangucaping Pangeran (Firman Allah), papanggeran (ketetapan nilai etika), ihrom, mi'raj, tubadil, munajat, maurid al-isq (muara rindu), uluhiyah, ubudiyah, wirasa, sampurnaning panembah, sampurnaing pamuji, sampurnaning iman, hakikating tauhid, tarek, dan asma-asma Allah.

\section{Keterangan}

Kondisi fisik naskah ini masih baik, hanya tidak bercover lagi. Naskah ini tidak menggunkan penomoran halaman, tetapi meng-gunakan kata alihan (catchword) di bawah teks naskah sebelah kiri. Warna tinta keseluruhan teks naskah menggunakan warna hitam kecuali rubrikasi baru atau penulisan pasal menggunakan warna merah. Menurut Elang Panji Jaya Prawirakusuma, naskah ini berasal dari leluhurnya yang bernama Pangeran Akhmad Martakusuma (18561936) dari Keraton Kasepuhan Cirebon. 


\section{Primbon Tarekat}

36/EPJ-04/Tw-1/TA/2012

Kertas Daluang
Pegon

$18,5 \times 13 \mathrm{~cm} \quad 15,3 \times 10 \mathrm{~cm}$
$66 \mathrm{hlm}$

9 baris/hlm

\section{Pengarang}

\section{Penulisan}

\section{Kolofon}

\section{Cap Kertas}

\section{Gambaran Isi}

Pada bagian awal hingga paruh naskah ini membahas tentang astrologi (perbintangan) yang pembahasanya meliputi; bintang haml (bulan Muharam) sifatnya api, bintang tsur (bulan Safar) sifatnya bumi, bintang jawaz (bulan Mulud) sifatnya angin, bintang syarathan (bulan Rabiul Awal) sifatnya air telaga, bulan asad (bulan Jumail Awal) sifatnya api dapur, bintang subula (bulan Jumadil Akhir) sifatnya bumi rendah, bintang mizan (bulan Rajab) sifatnya angin bawah, bintang 'aqrab (bulan Sya'ban) sifatnya air laut, bintang qus (bulan Ramadhan) sifatnya api pusaran, bintang jadi (bulan Syawal) sifatnya bumi kuning, bintang dalwi (bulan Dzul Qo'dah) sifatnya angin, bintang hut (bulan Haji/Dzulhijjah) sifatnya air sungai dan pembahasan selanjutnya mengenai sifat-sifat dan watak manusia.

Pada bagian akhir naskah ini menguraikan tentang Tarekat Syatariyah dengan zikir, daerah, ilmu tauhid, dan tentang martabat tujuh yang terdiri dari alam ahadiyah, alam wahdah, alam wahidiyah, alam arwah, alam mitsal, alam ajsam, dan alam insan kamil yang biasa dijelaskan dalam naskah-naskah Tarekat Syatariyah dan Muhammadiyah terdahulu. 


\section{Keterangan}

Secara umum, kondisi fisik naskah ini masih baik hanya tidak bercover. Naskah ini tidak menggunkan penomoran halaman dan tidak menggunakan kata alihan (catchword). Warna tinta keseluruhan teks naskah menggunakan warna hitam. Menurut pemiliknya, Elang Panji Jaya Prawirakusuma, naskah ini berasal dari leluhurnya yang bernama Pangeran Akhmad Martakusuma (18561936) dari Keraton Kasepuhan Cirebon. 


\section{Doa-Doa Tasawuf}

37/EPJ-08/Tw-1/TA/2012

Kertas Eropa
Pegon

Prosa

$58 \mathrm{hlm}$

$21 \times 17 \mathrm{~cm}$

$11 \mathrm{baris} / \mathrm{hlm}$

\section{Pengarang}

\section{Penulisan}

\section{Kolofon}

\section{Cap Kertas}

\section{Gambaran Isi}

Naskah yang satu ini memuat doa-doa dan ayat limabelas, doa-doa yang disebutkan di antaranya adalah doa nurbuat, doa nisfu sya'ban, doa basmalah, doa Nabi Sulaiman as, dan doa akasah. Selanjutnya, naskah ini berbicara tentang Nur Muhammad sebagaimana yang dijelaskan dalam naskah-naskah Tarekat Muhammadiyah dengan mengaitkan bagian-bagianya dalam diri manusia yang meliputi hati, rasa, sukma, dan lainya.

\section{Keterangan}

Kondisi fisik naskah ini sudah rusak dan ada beberapa halaman yang hilang. Naskah ini tidak memiliki watermark sebagaimana naskah yang menggunakan kertas Eropa yang lain, sekalipun demikian, kertas naskah ini memiliki clain lines (garis tebal) sebanyak 6 (enam) garis per 15,5 cm dan memiliki laid lines (garis tipis) sebanyak 9 (sembilan) tiap per $1 \mathrm{~cm}$-nya. Keseluruhan tinta yang digunakan berwarna hitam dan naskah ini tidak menggunakan penomoran halaman. 


\title{
Tarekat Qadariyyah dan Jazuliyah
}

\author{
38/EPJ-14/Tw-1/TA/2012 \\ Pegon \\ Prosa \\ $88 \mathrm{hlm}$ \\ Kertas Eropa \\ $16 \times 10,5 \mathrm{~cm} \quad 13 \times 7,5 \mathrm{~cm}$ \\ 9 baris/hlm
}

\section{Pengarang}

Syeikh Taqyu Abu Abdillah Muhammad Sulaiman al-Jazuli (nama pengarang ini terdapat pada lembar ke-18).

\section{Penulisan}

\section{Kolofon}

\section{Cap Kertas}

Propatria - zoonen - Putri Dalam Pagar

\section{Gambaran Isi}

Pada permulaannya, naskah ini berisi Yasin Fadhillah yang syarat dengan doa-doa yang diselipkan pada akhir hampir setiap ayat surat Yasin. Menurut pemiliknya, Elang Panji Jaya, Yasin Fadhillah selalu dibaca oleh para pendahulu (orang tua dahulu) pada setiap malam Jumat, terutama Jumat Kliwon. Selanjutnya, naskah ini menguraikan tentang tarekat Qadiriyah dan daerah zikir Qadiriyah yang dibantu dengan keterangan gambar daerah zikir. Pada bagian selanjutnya, naskah ini memuat Kitab Dalailul Khairat yang masyhur disebut dengan Tarekat Jazuliyah. Tarekat Jazuliyah ini tidak membutuhkan metode zikir yang dijelaskan dengan daerah zikir, seperti tarekat Qadiriyah, Syatariyah, Muhammadiyah, Naqsyabandiyah, dan lainya. 


\section{Keterangan}

Kondisi fisik naskah ini sudah rusak dan ada beberapa halaman yang hilang dan sudah berlubang. Naskah ini menggunakan dua bahasa; pada bagian awal naskah ini menggunakan bahasa Cirebon/Jawa dalam menjelaskan tentang Tarekat Qadiriyah, dan pada halaman selanjutnya bahasa Arab dalam menjelaskan/ memuat Tarekat Jazuliyah. Terdapat ilustrasi kepala, puser, dan hati untuk menjelaskan daerah zikir Qadiriyah. Tinta menggunakan warna hitam dan merah untuk rubrikasi baru. 


\section{Nabi Pinaras}

39/EPJ-21/Tw-1/TA/2012

Pegon

Prosa

$38 \mathrm{hlm}$

Kertas Eropa

$16,5 \times 10,5 \mathrm{~cm}$

$12,7 \times 7,5 \mathrm{~cm}$

9 baris/hlm

\section{Pengarang}

\section{Penulisan}

\section{Kolofon}

\section{Cap Kertas}

Propatria - Putri Pegang Tombak

\section{Gambaran Isi}

Ajaran tasawuf yang terkandung dalam naskah ini bersifat tersirat bukan tersurat. Ajaran itu berupa kesucian hati yang di peroleh nabi dan rasul, agar layak meneui Malaikat Jabarail yang menjadi perantara dirinya dan Allah. Sehingga sang nabi-rasul ini membersihkan diri (ber-pinaras) untuk mencapai kedekatan dengan-Nya. Selanjutnya, naskah ini menjelaskan tentang martabat tujuh yang biasa dijelaskan pada naskah Tarekat Syatariyah dan Muhammadiyah. Pembahasan dilanjutkan dengan asal-usul Nabi Muhammad SAW - Nur Muhammad yang tercipta dari Cahaya Ilahi.

\section{Keterangan}

Kondisi fisik naskah ini sudah rusak parah sehingga bagian sampingnya robek-robek dan kusam. Naskah ini tidak menggunakan penomoran halaman dan kata alihan (catchword). Tinta yang digunakan seluruhnya berwarna hitam dan tidak ada iluminasi ataupun ilustrasi. Karena ukuranya yang kecil, naskah ini mirip buku saku yang mudah di bawa ke mana-mana, atau mungkin juga dahulunya diperlakukan seperti itu. 
Tarekat Syatariyah dan Muhammadiyah

40/EPJ-22/Tw-1/TA/2012

Kertas Eropa
Pegon

$16,5 \times 10,5 \mathrm{~cm}$

$12,7 \times 7,5 \mathrm{~cm}$
$28 \mathrm{hlm}$

9 baris $/ \mathrm{hlm}$

\section{Pengarang}

\section{Penulisan}

\section{Kolofon}

\section{Cap Kertas}

Propatria - Singa dalam Lingkaran Mahkota

\section{Gambaran Isi}

Berbeda dengan naskah-naskah petarekan yang lain, naskah ini lebih dahulu menjelaskan tentang Tarekat Muhammadiyah, baru kemudian menjelaskan Tarekat Syatariyah. Karena pejelasan Tarekat Muhammadiyah selalu belakangan setelah penjelasan Tarekat Syatariyah dalam banyak naskah, sehingga banyak kalangan mengganggap tingkatan Tarekat Muhammadiyah lebih tinggi di banding Syatariyah. Selain memuat dan menjelaskan Tarekat Muhammadiyah dan Syatariyah, nash ini juga menjelaskan tentang sifat-sifat Allah yang sering disebut dengan ilmu tauhid.

\section{Keterangan}

Kondisi fisik naskah ini sudah lusuh dan kusam jika tidak dikatakan rusak. Naskah ini juga tidak menggunakan penomoran halaman dan kata alihan (catchword). Dalam naskah ini ada dua ilustrasi yang menggambarkan daerah zikir Syatariyah dan daerah zikir Muhammadiyah. Hal yang menarik dalam naskah ini adalah ilustrasi itu menggunakan tinta berwarna merah. 


\section{Tarekat Syatariyah dan Naqsyabandiyah}
41/EPJ-24/Tw-1/TA/2012
Pegon
Prosa
$54 \mathrm{hlm}$
Kertas Bergaris
$21 \times 16,5 \mathrm{~cm}$
$17,5 \times 12,5 \mathrm{~cm}$
12 baris/hlm

\section{Pengarang}

\section{Penulisan}

\section{Kolofon}

\section{Cap Kertas}

School Schrift Department O En E

\section{Gambaran Isi}

Pada halaman 3, naskah ini menjelaskan dadalan/silsilah sanad Tarekat Syatariyah yang berisi nama-nama periwayat Syatariyah hingga Nabi Muhammad SAW. Selanjutnya pada halaman 7, naskah ini menceritakan tentang tata cara bai'at dan talqin sebagai titik awal permulaan murid (salik) dalam mengamalkan tarekat. Selanjutnya pada halaman 11, naskah ini menjelaskan tentang sifat-sifat murid tarekat yang tentunya dapat menjadi bimbingan bagiya. Setelah itu, naskah ini menjelaskan tentang ilmu tauhid yang meliputi zat, sifat, dan af'al Allah. Pada halaman selanjutnya, halaman 24-50, naskah ini membicarakan tentang martabat tujuh. Hal yang paling menarik dalam naskah, pada halman 5152, memberikan/meng-ijazah-kan doa guna menghadapi perang dengan penjajah Belanda.

\section{Keterangan}

Kondisi fisik naskah ini sangat baik dengan tulisan yang terbaca jelas dan menggunakan sampul naskah ini berwarna coklat. Tinta yang digunakan berwarna hitam dan merah untuk rubrikasi baru 
atau inti pembahasan dan mengguakan bahasa Cirebon atau Jawa. Naskah ini tidak menggunakan penomoran halaman dan kata alihan (catchword), akan tetapi naskah ini menggunakan ilustrasi untuk menjelaskan Tarekat Syatariyah dengan gambar laa ilaha illallah muhammadur Rasulullah yang dibentuk mengikuti dua bahu, pusar, dan hati. Dalam naskah ini juga terdapat catatan yang menjelaskan tentang Pangeran Abdullah yang memberi ijazah tarekat/naskah ini. 


\section{Doa-Doa dan Tarekat Muhammadiyah}

$\begin{array}{cccc}\text { 42/EPJ-31/Tw-1/TA/2012 } & \text { Pegon } & \text { Prosa } & 182 \mathrm{hlm} \\ \text { Kertas Bergaris } & 14,5 \times 9 \mathrm{~cm} & 12 \times 8,3 \mathrm{~cm} & 9 \text { baris } / \mathrm{h} / \mathrm{m}\end{array}$

\section{Pengarang}

\section{Penulisan}

\section{Kolofon}

\section{Cap Kertas}

\section{Gambaran Isi}

Pada halaman awal, naskah ini memuat Doa Mandi yang harus di baca pad setiap akan mandi dan doa tersebut menggunakan bahasa Cirebon. Selanjutnya, naskah ini memuat ilmu-ilmu aji kedhahiran yang mirip dengan mantra-mantra dalam ilmu kanuragan. Setelah itu, naskah ini baru menjelaskan tentang Tarekat Muhammadiyah yang pembahasanya meliputi Nur Muhammad yang lazim dikenal dengan istilah hakikat Muhammadiyah, daerah zikir Muhammadiyah, dan lambang Tarekat Muhammadiyah yang berupa kesatuan lapaz Allah dan Muhammad dalam bentuk mirip manusia. Dalam naskah ini juga, ada penjelasan tentang tabarukan (meminta berkah) dari Syeikh Akbar. Sayangnya, tidak ada penjelasan teks atau narasumber yang dapat mengurikan tentang jatidiri seseorang yang berjuluk Syeikh Akbar.

\section{Keterangan}

Kondisi fisik naskah ini sangat baik, dan masih menggunakan cover dengan kertas karton, sampul kain berwarna biru. Tinta yang digunakan berwarna hitam secara keseluruhan. Naskah ini menggunakan bahasa Cirebon. Naskah ini tidak menggunakan penomoran halaman atau pun kata alihan (catchword). 


\begin{tabular}{cccc}
\multicolumn{4}{c}{ Keimanan dan Tasawuf } \\
43/EPJ-34/Tw-1/TA/2012 & Jawa & Prosa & $36 \mathrm{hlm}$ \\
Kertas Daluang & $23,5 \times 15,5 \mathrm{~cm}$ & $19 \times 12 \mathrm{~cm}$ & $15 \mathrm{baris} / \mathrm{hlm}$
\end{tabular}

\section{Pengarang}

\section{Penulisan}

\section{Kolofon}

\section{Cap Kertas}

\section{Gambaran Isi}

Naskah yang berbahasa Cirebon dengan aksara Jawa atau Carakan ini memuat tentang ilmu kedhahiran dan ilmu kebathinan, dua ilmu yang oleh kebanyakan orang dianggap sebagai ilmu kejawen, yang mengarah pada ilmu Tauhid dengan semangat tasawuf. Naskah ini memulai pembahasannya dengn menyebutkan bismillahir rahmanir rahiim. Selanjutnya, naskah ini berbicara tentang hakikat manusia yang sebenarnya merupakan anugerah Allah berdasarkan keimanan, wawayangan kanugrahaning ngiman (hlm. 2 baris ke 3 dan 4). Ilmu syari'at, ilmu hakikat, ilmu tarekat, dan ilmu makrifat menjadi pembahasan yang penting, sehingga naskah ini menegaskan tentang titik tolak dan sumber keimanan yang sangat penting; pangeran hiku mashdaring ngiman, Allah SWT itu sumber Iman (hlm. 3 baris ke 8 dan 9).

\section{Keterangan}

Kondisi naskah ini sudah berlubang atau bolong-bolong, kertas naskah sudah berwarna hitam kecoklatan dan tampak kumal, walau demikian tulisan masih bisa dibaca. Tinta naskah ini berwarna hitam, tidak ada penomoran halaman, penomoran dilakukan kemudian dengaan pinsil menggunakan huruf latin. Naskah ini juga tidak menggunakan iluminasi atau ilustrasi. 
Seseratan Pangeran Patih Sulareja Martasinga

44/EPJ-35/Tw-1/TA/2012

Jawa

Prosa

$50 \mathrm{hlm}$

Kertas Eropa

$21,5 \times 16 \mathrm{~cm}$

$17 \times 12 \mathrm{~cm}$

13 baris/hlm

\section{Pengarang}

Pangeran Patih Sulareja Martasinaga (Tahun 1820 M). Keterangan angka tahun ini diperoleh daari pemilik naskah yaitu Pangeran Panji Jaya Prawirakusuma.

\section{Penulisan}

\section{Kolofon}

\section{Cap Kertas}

Dua Tangkai Kuncup Bunga Lili

\section{Gambaran Isi}

Naskah ini memulai pembahasannya dengan basmalah. Secara keseluruhan, naskah ini mengarahkan pembacanya untuk mencapai kesempurnaan hidup dan kesempurnaan mati. Pembicaraan tentang kesempurnaan hidup dan mati tertulis pada halaman 2 baris ke 2 dan 3. Selanjutnya, kesempurnaan hidup dan mati ini dimulai dengan pengenalan terhadap bagian-bagian nafsu yang sering menjerumuskan orang pada kehancuran hidup dan kematiannya.

\section{Keterangan}

Kondisi fisik naskah ini sudah rusak, robek pada bagian pinggirnya. Naskah ini juga sudah lepas dari sampul dan kurasanya. Tintanya berwarna hitam dan sudah membentuk bercak-bercak yang menutupi watermark. Walau demikian, tulisan masih bisa dibaca. Judul naskah ini mengambil dari lembar pertama yang dibubuhi tanda tangan oleh penulisnya, Pangeran Patih Sulareja Martasinga. 


$$
\begin{array}{cccc}
\multicolumn{4}{c}{\text { Ngilmi Sampurna }} \\
\text { 45/EPJ-48/Tw-1/TA/2012 } & \text { Jawa } & \text { Prosa } & 48 \mathrm{hlm} \\
\text { Kertas Eropa } & 10,5 \times 8,3 \mathrm{~cm} & 8,3 \times 6,5 \mathrm{~cm} & 8 \mathrm{baris} / \mathrm{hlm}
\end{array}
$$

\section{Pengarang}

Pangeran Suryamanggala

\section{Penulisan}

\section{Kolofon}

Kagungan Pangeran Suryamanggala (milik Pangern Suryamanggala).

\section{Cap Kertas}

\section{Gambaran Isi}

Naskah ini memulai pembahasannya dengan basmalah. Seperti naskah sebelumnya, secara keseluruhan, naskah ini juga membahas tentang kesempurnaan, mungkin juga bermaksud mengarahkan pembacanya untuk mencapai kesempurnaan hidup dan mati, sebagaimana naskah sebelumnya. Di permulaan, naskah ini berbunyi; bismillahir rahmanir rahim.....dyan punika kawikanana denira ngilmi kang sampurna tur kang hanyampurnakaken.... (Dengan menyebut Nama Allah yang Maha Pengasih dan Penyayang....kitab ini, ketahuilah olehmu bahwa Ilmu Sampurna dan yang menyempurnakan.....). Kutipan ini diambil dari halaman 3 , baris ke 1-4.

\section{Keterangan}

Kondisi fisik naskah ini masih agak utuh hanya sudah lepas dari covernya. Menurut Pangeran Panji Jaya yang menjadi pewaris naskah ini, Pangeran Suryamanggala yang diduga Penulis dan menjadi pemilik naskah ini (lihat kolofon) merupakan sesepuh 
Desa Mertasinga yang cukup disegani. Tinta naskah ini berwarna hitam daan naskah ini tidak menggunakan penomoran halaman, penomoran dilakukan kemudian dengan menggunakan pensil dan huruf latin. Naskah ini masih tampak bersih dan tulisanya jelas terbaca. 


\section{Bayan}

$\begin{array}{cccc}\text { 46/EPJ-50/Tw-1/TA/2012 } & \text { Pegon } & \text { Prosa } & 18 \mathrm{hlm} \\ \text { Kertas Eropa } & 19,5 \times 12,3 \mathrm{~cm} & 17,5 \times 10 \mathrm{~cm} & 11 \mathrm{baris} / \mathrm{hlm}\end{array}$

\section{Pengarang}

\section{Penulisan}

\section{Kolofon}

\section{Cap Kertas}

D \& C - Sekuntum Bunga Tulip Mekar

\section{Gambaran Isi}

Kandungan naskah ini, secara garis besar, memuat tiga masalah yang meliputi tauhid, tasawuf, dan sejarah. Kesejarahan dalam naskah ini memuat tentang silsilah Kanjeng Susuhunan Jati Cirebon, Sunan Gunungjati, hingga sampai kepada Rasulullah SAW. Pada halaman 9, naskah ini berbunyi; fa'lam, maka akarep isun ing anyatakaken bayaning ma'rifat lan ru'yah (ketahuilah, saya bermaksud ingin menjelaskan tentang makrifat dan rukyah).

\section{Keterangan}

Kondisi fisik naskah ini masih agak utuh hanya sudah lepas dari covernya. Menurut Pangeran Panji Jaya yang menjadi pewaris naskah ini, Pangeran Suryamanggala yang diduga Penulis dan menjadi pemilik naskah ini (lihat kolofon) merupakan sesepuh Desa Mertasinga yang cukup disegani. Tinta naskah ini berwarna hitam daan naskah ini tidak menggunakan penomoran halaman, penomoran dilakukan kemudian dengan menggunakan pensil dan huruf latin. Naskah ini masih tampak bersih dan tulisanya jelas terbaca. 


$$
\begin{array}{cccc}
\multicolumn{4}{c}{\text { Babad dan Tasawuf }} \\
\text { 47/EPJ-51/Tw-1/TA/2012 } & \text { Jawa } & \text { Puisi \& Prosa } & 142 \mathrm{hlm} \\
\text { Kertas Eropa } & 21 \times 16,5 \mathrm{~cm} & 18,5 \times 13,5 \mathrm{~cm} & 14 \mathrm{baris} / \mathrm{hlm}
\end{array}
$$

\section{Pengarang}

\section{Penulisan}

\section{Kolofon}

\section{Cap Kertas}

Propatria - Singa Dalam Lingkaran Mahkota

\section{Gambaran Isi}

Naskah ini memuat dua kitab yang berbeda. Kitab yang pertama berisi tentang babad atau cerita yang tersusu dalam tembang kuno (Pupuh Macapat). Pada halaman ke 26, naskah ini membicarakan tentang persiapan perang yang tersurat dalam Pupuh Pangkur; sadaya sami siyaga, mantri hageng ngageng teng negar, (semua telah siap siaga, para mantri dan pembesar negara).

Kitab kedua dalam naskah ini membahas tentang Manunggaling Kaula Gusti. Pada halaman pertama dari kitab kedua, naskah ini menegaskan tentang Manunggaling Kaula Gusti dengan kalimat; noli den wiru kawula kelawan gusti (kemudian disatukan hamba dengan Tuhan).

\section{Keterangan}

Kondisi fisik naskah ini sudah rusak, berlubang atau bolongbolong, kotor, dan sudah lepas dari covernya. Tinta yang digunakan berwarna hitam. Naskah ini tidak menggunakan kata alihan (catchword) atau pun penomoran halaman. Pada kitab bagian pertama dari naskah ini menggunakan ilustrasi cerita dengan gambar-gambar adegan wayang. 


\section{Lubabul Akhbar}

$\begin{array}{cccc}\text { 48/EPJ-57/Tw-1/TA/2012 } & \text { Pegon } & \text { Puisi \& Prosa } & 194 \mathrm{hlm} \\ \text { Kertas Daluang } & 22,5 \times 16,5 \mathrm{~cm} & 15 \times 11 \mathrm{~cm} & 11 \mathrm{baris} / \mathrm{hlm}\end{array}$

\section{Pengarang}

\section{Penulisan}

\section{Kolofon}

\section{Cap Kertas}

\section{Gambaran Isi}

Permulaan naskah ini memuat beberapa hadis-hadis yang shahih yang dilanjutkan dengan membahas urutan sanad (silsilah) hadis. Kemudian naskah ini menjelaskan sifat-sifat Allah yang lazim dalam ilmu tauhid. Selanjutnya, naskah ini membicarakan makna laa ilaaha illallah (tiada Tuhan selain Allah), laa faa'ila illallah (tiada yang berbuat kecuali Allah), laa hayya illallah (tiada yang hidup selain Allah), hingga ke maqam fana laa maujuda illallah (tiada maujud (ada) selain Allah). Setelah itu, naskah ini memuat kasidah (syair) yang berisi shalawat Nabi SAW dalam bahasa Arab. Kemudian pada bagian akhir naskah ini menjelaskan tentang cara-cara mendapatkan ilmu laduni yang sangat menarik dalam dunia tasawuf. Bagian akhir yang menjelaskan ilmu laduni ini menggunakan bahasa Cirebon.

\section{Keterangan}

Kondisi fisik naskah ini sudah rusak, berlubang atau bolongbolong, kotor, dan sudah lepas dari covernya. Tinta yang digunakan berwarna hitam. Naskah ini tidak menggunakan kata alihan (catchword) atau pun penomoran halaman. Pada kitab bagian pertama dari naskah ini menggunakan ilustrasi cerita dengan gambar-gambar adegan wayang. 


\section{Primbon}

$\begin{array}{cccc}\text { 49/KCR-007/Tw-1/TA/2012 } & \text { Pegon } & \text { Prosa } & 202 \mathrm{hlm} \\ \text { Kertas Daluang } & 29 \times 19,5 \mathrm{~cm} & 24,5 \times 15 \mathrm{~cm} & 21 \mathrm{baris} / \mathrm{hlm}\end{array}$

\section{Pengarang}

\section{Penulisan}

\section{Kolofon}

\section{Cap Kertas}

\section{Gambaran Isi}

Naskah cukup tebal dan besar ini mencakup berbagai disiplin ilmu, sehingga naskah ini disebut primbon. Sebutan primbon di Cirebon selalu mengarah kepada buku-buku/naskah-naskah yang memuat berbagai ilmu agama. Pada bagian pertama, naskah ini memuat tentang azimat, rajah, wifiq, mihir, dan doa-doa yang sering digunakan untuk pengobatan, pengasihan, perdagangan, dan hajat yang lain. Bagian kedua, naskah ini memut tentang shalatshalat sunah tertentu yang jarang dilakukan seperti shalat sunah Rebo Wekasan dan shalat sunah bulan Safar.

Pada bagian ketiga, naskah ini menjelaskan tentang ruh dan bagian-bagian ruh disertai dengan doa-doa yang terkait dengan ruh dalam pembahasan tersebut. Bagian keempat, naskah ini membahas tentang tasawuf secara lengkap.

\section{Keterangan}

Kondisi fisik naskah ini sudah rusak dan banyak yang berlubang. Tinta yang digunakan berwarna hitam. Aksara dalam naskah ini sebenarnya bukan hanya Pegon, tapi juga aksara Carakan/Jawa, dan aksara Arab. Naskah ini tidak menggunakan catchword (kata alihan) atau pun penomoran halaman. Disamping itu juga, naskah ini sudah lepas dari penjilidannya, tidak bercover lagi. 


\title{
Koleksi Keraton Kacirabonan
}

\author{
Hill al-Rumuz wa Mafatih al-Kunuz \\ 11/KCR-19/Tw-1/TA/2012 \\ Arab \\ Prosa \\ $246 \mathrm{hlm}$ \\ Kertas Daluang \\ $30,5 \times 21 \mathrm{~cm}$ \\ $20,5 \times 13,5 \mathrm{~cm}$ \\ 9 baris/hlm
}

\section{Pengarang}

Ibnu Abdullah Abu Muhammad al-Maghrabi Muhammad al-Thai Muhyidin Arabi (Ibnu Arabi)

\section{Penulisan}

Selesai penulisan naskah ini pada hari Kamis siang, 30 Syawal tahun $1185 \mathrm{H}$.

\section{Kolofan}

Tammat al-Kitab al-musamma hill al-rumuz shannafa al-Syeikh al-'alim al-fadhil al-imam al-'arif quthub al-aulia wa al-iraq almuhaqqiqiin bin abdillah abu muhammad al-maghrabi rahmat Allah 'alaih muhammad al-thaai al-ma'ruf bisyeikh rahmat Allah 'alaih muhyiddin a'rabi qaul al-haq wa khatama al-kitab fi yaum al-khamsi waqta al-qailulah wa fi al-syahri al-sawwal wa fi al-hilal tsalatsun wa fi sanah wawi hijrah al-nabi sholla Allah 'alaih wa sallam 1185 tammat.

\section{Cap Kertas}

\section{Gambaran Isi}

Bagian awal naskah ini memuat tentang doa-doa dan ayat-ayat Al-Qur'an dilanjutkan dengan pembahasan mengenai iman, Islam, dan ihsan. Penjelasan tentang makom asraf (termulia), ilmu kasbi (ilmu yang di peroleh dengan belajar), ilmu wahbi/laduni (ilmu yang di peroleh dengan syughul (tenggelam dalam zikir kepada Allah), tingkatan suluk yang tiga, taubat, inabah, dan hakikathakikat dijelaskan pada halaman berikutnya. Di dalam naskah ini 
juga dijelaskan tentang alam shagir (mikro kosmos) dan alam kabir (makro kosmos) secara detail. Selanjutnya, Ibnu Arabi menulis tentang prilaku para wali yang penuh pengharapan kepada Allah SWT dengan kalimat yang indah dan menyentuh perasaan:

wa idza badaa lail sami'tu hafifuhum wa aninuhum bitadloru'in wa sualin,

wa 'uyunuhm tajri bi faidli dumu'ihim mitsla anhayalil wabil.

Artinya:

Saat malam telah tampak,

Kudengar rintih dan tangis mereka,

Dengan rasa rendah diri dalam doanya,

Air mata mereka mengalir deras,

Menetes di kedua pelupuk mata,

Laksana cucuran hujan.

\section{Keterangan}

Naskah ini menggunakan bahasa dan aksara Arab dengan makna gandul (terjemahan ala pesantren, kitab gondrong, menggunakan harkat dan makna yang menjulur ke bawah) yang tertera di bawahnya. Warna tinta hitam dan merah untuk rubrikasi (pasal) baru dan kalimat-kalimat yang menjadi kata kunci bagi kitab ini. Tulisan cukup rapih dan sangat jelas terbaca. Naskah ini menjadi jawaban atas kesungguhan kalangan keraton Cirebon dalam mempelajari ilmu tasawuf secara mendalam dan langsung dari sumbernya. Sekaligus juga jawaban terhadap kecurigaan seseorang yang selalu mengidentikan paham keraton dengan paham kejawen yang berkembang selama ini. 


\section{Tasawuf}

12/KCR-13/Tw-1/TA/2012

Pegon

Prosa

$20 \mathrm{hlm}$

Kertas Daluang

$27 \times 17,5 \mathrm{~cm}$

$19,5 \times 12 \mathrm{~cm}$

$11 \mathrm{baris} / \mathrm{hlm}$

\section{Pengarang}

\section{Penulisan}

\section{Kolofan}

\section{Cap Kertas}

\section{Gambaran Isi}

Ihsan sebagai landasan dasar dalam ilmu tasawuf menjadi pokok pembahasan utama dalam naskah ini. Hal itu karena naskah ini dipermulaan pembahasannya menjelaskan tentang ihsan secara detail. Selanjutnya, naskah ini membahas tentang suluk yang menjadi salah satu cabang / metode dalam tasawuf. Kemudian birr al-waalidain (berbuat baik kepada kedua orang tua) mendapatkan porsi pembahasan yang cukup panjang. Pembahasan tentang hati yang terang atau hati yang bercahaya dikaitkan dengan pembahasan tentang zikir yang lazim dilakukan oleh kalangan penganut Tarekat Syatariyah.

\section{Keterangan}

Naskah yang hanya terdiri dari sepuluh lembar kertas ini sudah robek dan tidak bersampul. Aksara pegon dengan bahasa Cirebon ini tertuang dalam tinta yang seluruhnya berwana hitam. Naskah ini tampak tidak terawat dan perlu perhatian kita semua. 


\section{Layang Bab Kaweruh Lahir Batin}

13/KCR-13/Tw-1/TA/2012

Kertas Daluang
Jawa

Prosa

$84 \mathrm{hlm}$

\section{Pengarang}

\section{Penulisan}

\section{Kolofan}

\section{Cap Kertas}

\section{Gambaran Isi}

Naskah ini membahas tentang tasawuf dalam konteks budaya Jawa, yang lazim disebut kebatinan. Dari sanalah, peneliti terdahulu memberi naskah ini dengan judul Layang Bab Kaweruh Lahir Batin. Lanjutan pembahasan yang terkandung dalam naskah ini adalah tentang jati, dalam peristilahan tasawuf disebut hakikat, ilmu sejati, dan hal-hal yang berkaitan dengan rasa. Pembahasan ini tentunya dapat memberi pemahaman yang mudah terhadap pembaca yang berakar pada Tasawuf Jawa, atau dalam istilah yang lain disebut ilmu kebatinan.

\section{Keterangan}

Sekalipun naskah ini sudah kusam, coklat, dan kehitam-hitaman, tulisanya masih cukup terbaca dengan baik dan jelas. Halaman pertama naskah ini sudah rusak; ujung naskah membentuk gulungan-gulungan kecil atau keriting. Sepertinya naskah ini tidak terawat pada waktu dahulu atau usia yang sudah cukup tua. 


\section{Tarekat Syatariyah}

$\begin{array}{cccc}\text { 14/KCR-28/Tw-1/TA/2012 } & \text { Pegon } & \text { Prosa } & 36 \mathrm{hlm} \\ \text { Kertas Eropa } & 20,5 \times 16 \mathrm{~cm} & 16,8 \times 12,3 \mathrm{~cm} & 13 \mathrm{baris} / \mathrm{hlm}\end{array}$

\section{Pengarang}

\section{Penulisan}

\section{Kolofan}

\section{Cap Kertas}

Propatria - singa dalam lingkaran mahkota.

\section{Gambaran Isi}

Turun-turune atau silsilah guru Tarekat Syatariyah menjadi pembaahasan pemulaan buku ini. Selanjutnya, martabat pitu (martabat tujuh) menjadi pembahasan yang lazim dalam permulaan naskah-naskah tarekat di Cirebon. Jenis-jenis hati dibahas dengan menggunakan ilustrasi yang menyerupai bunga teratai dengan berbagai lapisannya yang tujuh. Kemudian adab dan tata cara berzikir, khususnya zikir Syatariyah, dijelaskan secara detail. Selanjutnya, naskah ini memberi ilustrasi daerah zikir Syatari yang digambarkan dengan dua bahu, hati, dan pusar. Karena di sekitar daerah itulah zikir Syatari ini berjalan. Selanjutnya, naskah ini memberikan informasi tentang beberapa doa-doa yang biasa digunakan di kalangan para pengikut Tarekat Syatariyah.

\section{Keterangan}

Kondisi naskah ini sudah rusak. Tetapi, naskah ini masih cukup memberikan informasi yang memadai tentang Tarekat Syatariyah. Naskah ini menggunakan tinta warna hitam, kecuali ilustrasi "zikir Syatariyah" menggunakan warna emas. Naskah yang hanya dua kuras ini sudah tidak bersampul dan lepas dari penjilidannya. 


\section{Tarekat Muhammadiyah}

15/KCR-29/Tw-1/TA/2012

Kertas Eropa
Pegon

Prosa

$20,5 \times 16 \mathrm{~cm} \quad 15 \times 11 \mathrm{~cm}$
$36 \mathrm{hlm}$

6-11 baris/hlm

\section{Pengarang}

\section{Penulisan}

\section{Kolofan}

\section{Cap Kertas}

Sihairl

\section{Gambaran Isi}

Tarekat Muhammadiyah yang merupakan tingkat lanjutan dari Tarekat Syatariyah ini masih jarang dikenal oleh kalangan luar, terutama kalangan akademisi. Dalam naskah ini, Tarekat Muhammadiayah dijelaskan secara gamblang dan menyeluruh. Di bagian awal, naskah ini menjelaskan tentang guru dhahir dan guru bathin yang patut menjadi sandaran bagi para murid/salik. Saking pentingnya posisi guru (mursyid) bagi keselamatan perjalanan tarek para salik, naskah ini mengutip wasiat Abu Yazid aAl-Bustami yang dikutip dari kitab Quut al-Quluub bahwa wajib bagi seorang murid yang hendak terjun ke dalam tarekat harus mempunyai guru. Selanjutnya, naskah ini menjelaskan tetang bagian-bagian kufur agar keimanan dan perjalanan tarekat mereka selamat sampai tujuan, yaitu makrifatullah dengan sempurna.

Selanjutnya, pembahasan beralih kepada penyatuan antara Allah SWT dan Muhammad SAW dalam zat, asma, sifat, dan af'al. Pembahasan selanjutnya tentang zikir Muhammadiyah itu sendiri yang diilustrasikan dengan daerah zikir Muhammadiyah. 


\section{Keterangan}

Kondisi fisik naskah ini masih cukup baik dengan penjilidan kertas karton tipis dengan menggunakan kain putih yang tampak baru. Pada awalnya naskah ini tidak menggunakan penomoran halaman, tampak dibagian atas tengah ada penomoran halaman dengan menggunakan angka latin. Warna tinta naskah ini menggunakan warna hitam sebagaimana naskah lainnya. 


\section{Amir}

16/KCR-35/Tw-1/TA/2012

Pegon

Prosa

$22 \mathrm{hlm}$

Kertas Eropa

$20 \times 12,8 \mathrm{~cm}$

$17 \times 11 \mathrm{~cm}$

10 baris/hlm

\section{Pengarang}

\section{Penulisan}

\section{Kolofan}

\section{Cap Kertas}

VDL-Tiga Tangkai Bunga Lili yang Terilat dalam Lingkaran Mahkota.

\section{Gambaran Isi}

Naskah ini membicarakan tentang tasawuf secara umum. Pada bagian awal naskah ini membahas tentang zuhud yang menjadi titik tolak dari perjalanan tasawuf. Selanjutnya, pembahasan tentang bid'ah yang sering menjadi polemik dikalangan umat Islam. Tak kalah pentingnya dengan masalah bid'ah, masalah nafsu juga menjadi sorotan yang cukup panjang dalam naskah ini. Selanjutnya, naskah ini membicarakan tentang syirik yang dapat melebur seluruh pahala amal sholeh manusia.

\section{Keterangan}

Kondisi fisik naskah ini sudah rusak dengan kondisi lubang-lubang dan kertas yang terlepas dari kurasannya. Karena rusaknya kondisi itu, naskah ini sampai tidak bersampul apalagi berjilid. Kondisi yang cukup memprihatinkan. 


\section{Tasawuf}

$\begin{array}{cccc}\text { 50/Ml-01/Tw-1/TA/2012 } & \text { Pegon } & \text { Prosa } & 26 \mathrm{hlm} \\ \text { Kertas Eropa } & 21,5 \times 16,5 \mathrm{~cm} & 16 \times 12 \mathrm{~cm} & 12-15-16 \text { baris } / \mathrm{hlm}\end{array}$

\section{Pengarang}

\section{Penulisan}

\section{Kolofon}

Wallahu a'lam bisshawab berkah Syeikh haji 'abdul muhyi ing karang tambah (tamat)

\section{Cap Kertas}

Propatria - Singa Memegang Pedang dengan Prajurit Membawa Payung

\section{Gambaran Isi}

Naskah ini halaman depanya sudah hilang, permulaan naskah ini berbunyi: pahesan sawiji lan ruh Nabi kita Muhammad iku (naskah rusak). Anapun pahesan tungal roro kang (naskah rusak).... (suatu hiasan dan ruh Nabi kita Muhammad itu (naskah tidak terbaca karena berlubang). Adapun hiasan satu dua yang (naskah tidak terbaca karena berlubang). Selanjutnya, naskah ini menjelaskan tentang makrifat yang harus dimulai dengan pengenalan diri sendiri yang meliputi berbagai hal, yang pada puncaknya kita dapat makrifat kepada Allah SWT dengan sebenarnya. man 'arafa nafsahu faqad 'arafa rabbahu. Ikulah tunggalena dening sira den temen lan pikiren den temen den alus den becik. Drapon amarkoleha sira ing pangaweruh ira ing awakira lan mati sira sedelapun oranana sira ing awakira.

Pembahasan selanjutnya adalah tentang sifat 7 yang dinamakan dengan ruh idhafi, kemudian naskah ini menulis kuntu kanzan 
mukfiyan, Aku adalah perbendaharaan yang samar, sebuah hadis yang populer di kalangan sufi.

Selanjutnya, naskah ini menjelaskan tentang tanazul dan taraqi yang dimulai dengan mengutip al-insaanu sirri wa ana sirruhu, manusia adalah rahasiaku dan aku adalah rahasianya. Setelah manusia mengenali rahasia-rahasia yang ada dengan baik dan benar, maka manusia akan berhenti pada ke-fana-an yang membuatnya tenggelam dalam kemahaan yang tak terkira, laa ana illa anta, tiada Aku selain Engkau.

\section{Keterangan}

Naskah ini berada di kediaman Dr. Ma'rifat Iman KH. MA di Gang Jambu Kampung Utan Tangerang Banten, beliau masih kerabat Keraton Kacirebonan. Orang tua beliau adalah seorang pengulu (suatu jabatan di Keraton Kacirebonan yang mengurusi masalah keagamaan) yang mengabdi pada Keraton Kacirebonan.

Kondisi fisik naskah ini sudah rusak, tidak berjilid atau bersampul, banyak halaman yang robek, dan beberapa halaman sudah lepas dari jahitanya. Tinta yang digunakan berwarna hitam, tidak ada penomoran halaman, tidak menggunakan iluminasi atau ilustrasi, dan bahasa yang digunakan dalam naskah ini adalah bahasa Cirebon-Jawa, kecuali halaman yang memuat doa akasah, halaman ini juga terdiri dari 9 baris teks perhalaman. 


\section{DAFTAR PUSTAKA}

\section{Sumber Buku}

Azra, Azyumardi. 2007. Jaringan Ulama Timur Tengah dan Kepulauan Nusantara Abad XVII dan XVIII: Akar Pembaruan Islam Indonesia. Jakarta: Kencana Prenada Group.

Bafadhal (ed.), Fadhal. 2006. Kumpulan Sinopsis Hasil-Hasil Penelitian

Lektur Keagamaan. Jakarta; Badan Litbang dan Diklat Departemen Agama.

Barginsky, V.I. 1993. The System of Classical Malay Literature. Leiden; KITLV Press.

Baried dkk, Siti Baroroh. 1994. Pengantar Teori Filologi. Yogyakarta: Badan Penelitian dan Publikasi Fakultas, UGM Yogyakarta.

Dain, A. 1975. Les Manuscrits. Paris, Les Belles Letters.

Fathurahman, Oman. 2008. Tarekat Syattariyah di Minangkabau: Teks dan Konteks. Jakarta: Prenada Media Group, EFEO, PPIM UIN Jakarta dan KITLV. 2010. Filologi dan Islam Indonesia. Jakarta: Puslitbang Lektur Keagamaan, Badan Litbang dan Diklat Kementerian Agama. Ikram, Achadiati. 1997, Filologia Nusantara. Jakarta: Pustaka Jaya. Johns, A. 1987. Tentang Kaum Mistik Islam dan Penulisan Sejarah," dalam Sejarah dan Masyarakat: Lintasan Historis Islam di Indonesia. ed. Taufik Abdullah. terj. Mien Joebhaar dkk. Jakarta: Pustaka Firdaus.

Mulyadi, Sri Wulan Rujiati. 1994. Kodikologi Melayu di Indonesia, Lembar Sastra Edisi Khusus No. 24. Depok, Fakultas Sastra Universitas Indonesia.

Sudewa, Alex. "Filologi dalam Era Pembangunan". Majalah Basis, Oktober 1984. 
Uka Tjandrasasmita, Uka. 2009. Arkeologi Islam Nusantara. Jakarta; Kepustakaan Populer Gramedia.

\section{Sumber Website}

Azra, Azyumardi. Naskah Islam Indonesia, http://www.uinjkt.ac.id/ index.php/section-blog/28-artikel/1553-naskah-islamindonesia.html. Rabu, 24 Nopember 2012. 


\section{DAFTAR INDEKS}

A

'Abd as-Shamad al-Jawi al-Palimbani 16,113

Abdullah Syattari 103

Abdul Qadir al-Jailani 103

Abu Zakaria al-Anshari 335, 336, 338, 340

Aceh vi, 6, 11, 12, 15, 16, 18, 19, 20, $21,22,24,26,28,30,32,33,34$, $36,37,38,40,41,42,43,44,46$, $47,48,50,52,54,55,56,57,58$, $60,62,64,65,66,68,70,72,74$, $76,78,80,82,84,85,86,88,89$, $90,92,93,94,95,96,98,100$, $102,104,106,108,110,112$, $114,116,118,127,134,157$, 159, 194, 253, 326, 343

Aceh Darussalam 157

Ahl al-asbab 272

Ahl al-Haqq 79, 82

Ahl al-Sunnah wa al-Jamaah 17, 42, 45,113

Ahl al-tajrid 272

Ahl Kitab 78, 81

Ahl kasyaf 18, 20

Aksara latin 17

Al-Qur'an 22, 24, 36, 57, 59, 63, 75, 76, 96, 101, 112, 115, 117, 118, 153, 161, 194, 208, 232, 278, 310,397

Aqli 30, 115, 117

Aqsam 17, 113
Arab v, vi, 3, 18, 19, 28, 30, 34, 39, 47, $59,72,73,82,95,98,104,105$, $112,117,120,121,122,123$, $124,126,127,129,131,132$, 133, 134, 136, 137, 139, 141, $142,143,144,145,146,147$, $148,149,150,152,154,156$, $157,158,159,160,161,162$, $163,164,166,167,168,169$, 170, 171, 173, 174, 175, 176, $178,180,182,183,184,185$, 187, 189, 191, 192, 194, 195, 196, 198, 200, 201, 203, 204, 206, 208, 210, 211, 213, 214, $215,217,219,220,222,223$, 224, 225, 227, 228, 229, 230, 231, 232, 233, 234, 236, 237, 238, 239, 240, 241, 242, 243, 246, 247, 248, 249, 250, 251, $252,253,254,255,257,258$, 259, 261, 262, 264, 265, 266, 268, 269, 272, 273, 274, 275, 276, 278, 280, 282, 285, 291, $303,309,311,312,313,314$, $316,317,318,319,320,321$, $322,327,329,330,331,334$, $340,341,362,365,366,371$, $383,395,396,397,398$

Arab Jawi 117

A'yan kharjiyah 143

A'yan tsabitah 63, 68, 110, 112, 143

Azali 100, 253, 264 
Azimat 161, 173, 174, 365, 396

Azyumardi Azra 3, 6

B

Banten 11, 12, 316, 318, 320, 322, $324,326,328,330,332,343$, 406

Baqa 264, 302, 303

Barahimah 78, 81

Belanda 3, 4, 8, 386

C

Cagar budaya vi, 4, 5, 7

Cap kertas 11

Catchword 10, 364, 369, 371, 372, $373,374,375,376,378,380$, $384,385,387,388,394,395$, 396

Clain lines 374, 381

Countermark 11, 374

D

Dahriyah 78, 81

Dhuha 16, 30, 41, 66, 78, 255, 268, 283,334

Dzuhur 41, 70, 115, 132

$\mathbf{F}$

Fadilah 162

Falsafi 70, 90, 142, 168, 190, 240, 285, 290, 298, 302, 303, 311

Fana 149, 157, 255, 264, 274, 297 $302,303,337,359,368,369$, 395,406

Filipina 4

Filologi 4, 8

Filosofis 37, 73, 109, 124, 148, 309

Fiqih $4,6,12,17,42,45,96,113,178$, $184,257,258,262,296,334$, 350

Firqah 337, 338

Fundamental 167
G

Glossa 351

H

Hakikat muhammadiyah 349

Hamdaniyah 28

Hamzah Fansuri 79, 82, 115, 117, 139

I

IAIN Jambi 236

Ideologi $\mathrm{v}$

ljazah 141, 152, 170, 183, 184, 200, $201,210,242,243,386,387$

Ikhtilaf 78, 81

Ilmu tasawuf 96, 121, 127, 129, 176, $181,253,305,308,317,318$, 368, 369, 398, 399

Iluminasi 10, 11, 43, 79, 293, 314, $364,371,374,376,377,384$, 389,406

Ilustrasi 10, 11, 30, 32, 62, 109, 110, $123,133,144,155,173,178$, $179,181,218,222,256,343$, $358,360,363,364,374,375$, $377,383,384,385,387,389$, $394,395,401,406$

Imam al-Ghazali 42, 45, 136, 187 India $v, 211$

Indonesia $v, 3,4,5,6,7,9,177,211$, 407,408

Insan kamil 96, 121, 143, 144, 340, $343,345,350,363,375,379$

Intelektualisme 3

Iradah 61, 20

Islam v, vi, 3, 4, 5, 6, 7, 8, 19, 25, 32, 37, $38,78,81,85,136,149,187$, 189, 204, 211, 220, 269, 278, $313,335,337,343,344,356$, $397,404,407,408$

Istihalah 30

Isyarah 109 
J

Jabariyah 79,82

Jahmiyah Murji'ah 79,82

Jaiz 30, 32, 37, 38, 39, 59, 61, 84, 87, $268,356,375$

Jakarta iii, iv, vi, 5, 11, 407, 408

Jawa Barat 11, 13, 334, 336, 338, 339, $340,342,344,346,348,350$, $352,354,356,358,360,362$, $364,366,368,370,372,374$ $376,378,380,382,384,386$, $388,390,392,394,396,398$, $400,402,404,406$

Jawi $16,19,22,24,25,26,28,29,34$, $36,41,42,45,47,48,50,52,61$, $63,65,66,68,69,70,72,73,75$, $76,78,81,82,84,87,92,93,95$, $96,98,100,103,106,107,109$, $110,113,115,117,118,129$, $146,187,237,266,275,287$, 289, 291, 293, 294, 296, 300, $303,304,308,314,326$

\section{K}

Kaifiyyah 131, 141

Kasyf 149

Katalog naskah 8, 11

Kementerian Agama iii, 4, 5, 6, 7, 407

Kertas Eropa 16, 18, 19, 20, 21, 22, 24,

$25,26,28,29,30,32,33,34,36$,

$37,38,39,41,42,45,47,50,52$,

$54,55,57,59,61,63,65,66,68$, $69,70,72,73,75,76,78,81,84$, $85,87,89,90,92,93,95,96,98$, $100,103,104,106,107,109$, $110,112,113,115,117,118$, $120,122,126,127,129,131$, $132,133,136,137,139,142$, $145,146,147,148,164,167$ $168,171,173,176,182,185$, $187,189,192,194,196,198$, $200,201,203,204,210,225$,
$227,228,229,234,236,238$, $239,240,241,246,247,248$, $249,250,251,252,253,254$, $255,257,258,259,260,261$, $262,264,265,266,268,269$, $272,274,278,280,282,284$, $285,286,287,289,290,293$, 294, 296, 298, 300, 302, 303, $305,306,307,308,309,311$, $312,313,316,317,318,319$, $325,328,330,331,334,340$, $343,348,349,350,354,356$, $358,359,360,362,363,364$, $365,366,368,370,371,372$, $373,374,376,378,381,382$, $384,385,390,391,393,394$, $401,402,404,405$

Khalwatiyyah 47

Kharijiyah 79, 82, 93

Khas Aceh 30

Khatam nubuwwah 123

Khatam tawajjuh 213, 222, 227

Khat farisi 195

Khat naskhi 17, 20, 26, 33, 36, 41, 43, $46,65,67,69,70,73,75,77,82$, $88,95,97,99,121,122,123$, $125,128,136,153,155,175$, $177,185,189,198,200,207$, 212

Kitab gondrong 362, 398

Kodikologi 8, 9, 407

Koleksi dan Katalogisasi i, iii, iv, v, 15 , $119,245,271,315,333$

Kolektor naskah 4

Kolofon 11, 20, 21, 23, 25, 29, 30, 38, $39,53,54,79,187,194,195$, 208, 228, 236, 242, 274, 296, $304,313,316,335,391,393$

\section{$\mathbf{L}$}

Laid lines 374,381

La ilaha illa Allah 22, 24, 26, 29, 30, 
$48,55,71,106,312$

Latin 17, 53, 273, 389, 392, 393, 403

\section{M}

Madzi 246

Majusi 78, 81

Makkiyah 75

Makrifat 66, 69, 95, 109, 112, 338, $352,358,366,368,369,370$, $376,377,389,393,405$

Malaysia 4

Mani 246

Manuscript 3, 8

Manuskrip v, vi, 4, 5

Martabat tujuh 22, 24, 96, 122, 132, 143, 144, 146, 147, 148, 158, $159,161,163,168,173,228$, 239, 241, 269, 305, 320, 343, $345,348,356,359,360,363$, $366,370,373,375,379,384$, 386,401

Matan 17, 29, 39, 59, 62, 64, 73, 82, $112,116,129,149,158,300$, 339,341

Mazhab 78, 81, 146, 177, 306

Mekkah 16, 113, 129, 152, 154, 187, $197,204,210,211,291,308$

Melayu vi, 3, 30, 36, 48, 65, 120, 121, $122,123,134,137,139,154$, $156,157,159,160,161,162$, $163,166,168,169,170,171$, $173,175,180,182,183,185$, $187,189,191,192,194,196$, 198, 200, 201, 203, 204, 206, 208, 211, 213, 214, 215, 217, $219,220,222,223,224,225$, 227, 229, 230, 231, 232, 234, 236, 237, 238, 241, 243, 246, $247,248,249,250,251,252$, 253, 254, 255, 257, 258, 259, 260, 261, 262, 264, 265, 266, 268, 269, 272, 273, 274, 275,
$276,278,280,282,284,285$, 286, 287, 289, 290, 291, 293, 294, 296, 297, 298, 300, 302, 303, 305, 306, 307, 308, 309, $311,312,313,326,407$

Muhammadiyah 63, 64, 170, 241, $346,347,348,349,350,356$, $359,360,373,375,379,381$, $382,384,385,388,402$

Mulhid 78, 81

Munjiyat 17, 114

Museum Negeri Aceh 12, 15, 20, 33, $36,41,43,46,65$

Museum Negeri Sumatera Utara 12

\section{$\mathbf{N}$}

Naqsyabandiyah 28, 107, 108, 120, 137, 141, 152, 154, 155, 156, $164,166,171,174,176,183$, 185, 211, 213, 214, 215, 217, 218, 219, 220, 222, 223, 225, 227, 230, 233, 234, 236, 237, $242,243,360,361,382,386$

Nash 112, 136, 148, 385

Naskah kuno 4, 5, 7, 8

Nasrani 78, 81

Nazam 47, 48, 54, 90, 112, 174, 175

Nisbah 28, 194, 206

Nur Allah 69, 173

Nur Muhammad 68, 89, 123, 127, 143, 144, 161, 178, 180, 189, 239, 366, 370, 381, 384, 388

Nuruddin ar-Raniry 26, 29, 106

Nusantara v, vi, 3, 4, 6, 17, 28, 113, $158,159,193,195,237$

Nuthqah 136

O

Oman Fathurahman 3, 5, 6 
P

Paganisme 78, 81

Perisai 50, 65, 75, 76, 104, 106, 107, $115,117,303,305,308,330$

Prosa 16, 18, 19, 20, 21, 22, 24, 25, 26, $28,29,30,32,33,34,36,37,38$, $39,41,42,45,47,48,50,52,54$, $57,59,61,63,65,66,68,69,70$, $72,73,75,76,78,81,84,85$, $87,92,93,95,96,98,100,103$, $104,106,107,109,110,113$, $115,117,118,120,121,122$, $123,124,126,127,129,131$, $132,133,134,136,137,139$, $141,142,143,144,145,146$, $147,148,149,150,152,154$, $156,157,158,159,160,161$, $162,163,164,167,168,169$, $170,171,173,176,178,180$, $182,183,185,187,189,191$, 192, 194, 196, 198, 200, 201, 203, 204, 206, 208, 210, 211, $213,214,215,217,219,220$, $222,223,224,225,227,228$, 229, 230, 231, 232, 233, 234, 236, 237, 238, 239, 240, 241, $242,243,246,247,248,249$, $250,251,252,253,254,255$, $257,258,259,260,261,262$, 264, 265, 266, 268, 269, 272, $274,276,278,280,282,284$ $285,286,287,289,290,291$, 293, 294, 296, 297, 298, 300, $302,303,305,306,307,308$, $309,311,312,313,316,317$, $318,319,320,321,322,323$, $324,325,326,327,328,329$, $330,331,334,340,342,343$, $346,348,349,350,354,356$, $358,359,360,362,363,364$, $365,366,368,370,371,372$, $373,374,375,376,378,379$,
$381,382,384,385,386,388$, 389, 390, 391, 393, 394, 395, 396, 397, 399, 400, 401, 402, 404,405

Q

Qadariyah 79, 82, 194, 206

Qawaid Islam 38

Qudrah 20,61

$\mathbf{R}$

Rafidhiyah 79,82

Riq'ah 126, 156, 169, 181, 184, 209, $210,242,314$

Rubrik 339, 361; rubrikasi 10, 17, 20, $26,33,34,36,41,43,46,53,61$, $65,67,69,70,73,82,94,95$, $97,99,117,120,121,122,123$, $125,126,128,130,132,133$, $135,138,140,142,143,144$, $146,147,148,149,151,156$, $157,158,159,160,165,166$, $167,168,173,195,204,213$, $214,217,219,221,224,226$, $227,228,229,230,232,233$, $234,235,236,237,238,239$, 240, 241, 243, 272, 275, 276, 278, 293, 296, 302, 306, 307, $318,341,348,351,355,357$, $365,370,378,383,386,398$

Ruh $41,68,69,100,109,110,136$, $167,250,253,262,309,345$, $359,360,362,363,396,405$

Ruh ibadah 167

Ruh idhafi 68, 309, 405

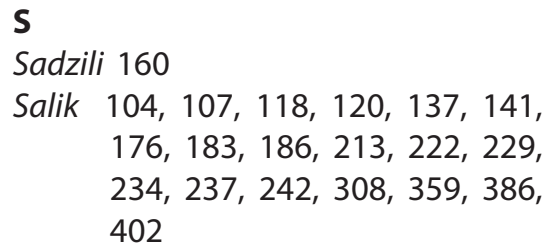
$176,183,186,213,222,229$, $234,237,242,308,359,386$, 402 
Skolia 140, 142, 143

Skriptorium 8

Spiritual 50, 52, 160

Suluah Community 12, 120

Suluk 55, 100, 101, 153, 164, 183, 223, $225,228,230,233,243,280$, 281, 290, 364, 371, 397, 399

Sumatera Barat 11, 12, 120, 122, 124, $126,128,130,132,134,136$, $138,140,142,144,146,148$, 150, 152, 154, 156, 158, 160, $162,164,166,168,170,172$, $174,176,178,180,182,184$, $186,188,190,192,194,196$, 198, 200, 202, 204, 206, 208, 210, 212, 214, 216, 218, 220, $222,224,226,228,230,231$, $232,234,236,238,240,242$, 244

Sumatera Selatan 11, 12, 272, 274, $276,278,280,282,284,286$, 288, 290, 292, 294, 296, 298, $300,302,304,306,308,310$, 312,314

Sumatera Utara 11, 12, 209, 246, 248, 250, 252, 254, 256, 258, 260, $262,264,266,268,270$

Sunan Kalijaga 354

Sunda vi, 353

Sunni 79,82

Syair 11, 34, 55, 72, 112, 192, 246, 395

Syamsuddin as-Sumatrani 79, 82, 117

Syattariyah 3, 28, 98, 103, 126, 228, $239,293,319,407$

Syofyan Hadi 12

\section{$\mathbf{T}$}

Taba'iyah 78, 81

Tajalli 132, 253, 262, 345, 362, 372

Tanazzul 122, 148

Tarekat al-Ba'aliyah 250
Tarekat Awaliyah 250

Tarekat Muhammadiyah 347, 348, $349,350,356,381,385,388$, 402

Tarekat Naqsyabandiyah 107, 108, 120, 137, 141, 152, 154, 156, 164, 166, 171, 174, 176, 183, $185,211,213,214,215,217$, 218, 219, 220, 222, 223, 225, $227,230,233,234,236,237$, $242,243,360,361$

Tarekat Qadiriyah 194, 195, 206, 251, 383

Tarekat Ratiniyah 250

Tarekat Rifa'iyyah 250

Tarekat Syatariyah 343, 346, 347, $348,356,358,359,360,365$, 370, 373, 379, 384, 385, 386, $387,399,401,402$

Tarekat Wafaiyyah 250

Tasawuf v, 16, 18, 20, 22, 24, 26, 28, $30,32,34,36,37,38,40,42$, $44,46,48,50,52,54,56,58,60$, $62,64,66,68,70,72,74,76,78$, $80,82,84,86,88,90,91,92,94$, $96,98,100,102,104,106,108$, $110,112,114,116,118,120$, $122,124,126,128,130,132$, $134,136,138,140,142,144$, $146,148,150,152,154,156$, $158,160,162,164,166,168$, $170,172,174,176,177,178$, 180, 182, 184, 186, 188, 189, 190, 192, 194, 196, 198, 200, 202, 204, 206, 208, 210, 212, $214,216,218,220,222,224$, 226, 228, 230, 232, 234, 236, 238, 239, 240, 241, 242, 244, $246,248,250,252,254,255$, 256, 258, 260, 262, 264, 266, 268, 270, 272, 274, 276, 278, 280, 282, 284, 286, 288, 290, 
292, 294, 296, 298, 300, 302, $304,306,308,310,312,314$, $316,317,318,320,322,324$, $326,328,330,332,334,336$, $338,340,342,344,346,348$, $350,352,354,356,358,360$, $362,364,366,368,370,372$, $373,374,375,376,378,380$, $381,382,384,386,388,389$, 390, 392, 394, 396, 398, 399, 400, 402, 404, 405, 406

Tasawuf falsafi 70, 90, 142, 168, 190, 240, 285, 290, 298, 302, 303, 311

Tasawuf muntahi 121, 122, 124, 148, 157,190

Tasawuf oriented 145

Taufik Abdullah v, 407

Tauhid 4, 6, 85, 123, 132, 176, 180, $184,220,234,257,262,268$, $269,276,287,296,300,302$, $335,336,338,340,356,358$, $365,366,370,375,378,379$, $385,386,393,395$

Tawajjuh 185, 196, 213, 214, 220, $222,223,225,227,236,243$

Tawarruk 185, 196

Tawassul 120, 131, 154, 166, 195, 225, 243

Tayyibah 33

Teks naskhi 92, 94, 201

Tuhfah 158, 228

$\mathbf{U}$

Ubudiyyah 18, 20

Uka Tjandrasasmita 5, 8, 408

Ushuluddin 17, 113, 115, 117, 274, 291

UU No. 11 Tahun 2010 4, 7

UU No. 43 Tahun 2007 4, 5, 7, 8

Uzlah 17, 73, 114

\section{W}

Wadi 246

Wahdatul wujud 69, 122, 150, 159, 287, 305

Watermark 11, 374, 381, 390

Wayang 375, 394, 395

Wujudiyah 26, 79, 82, 290

$Y$

Yahudi 78,81

$\mathbf{Z}$

Zaruq 73

Zikir 22, 24, 28, 33, 34, 41, 43, 45, 47, $48,55,70,73,84,90,93,98$, $103,107,118,137,141,160$, $174,176,185,196,213,214$, 215, 217, 218, 220, 222, 227, 230, 232, 233, 234, 236, 237, $250,251,255,256,257,264$, 265, 287, 289, 294, 299, 303, $316,336,342,343,346,348$, $358,359,360,370,371,374$, $379,382,383,385,388,397$, 399, 401, 402

Zikir Muhammadiyah 385, 388, 402 Zuhud 224, 404 
[416] 